
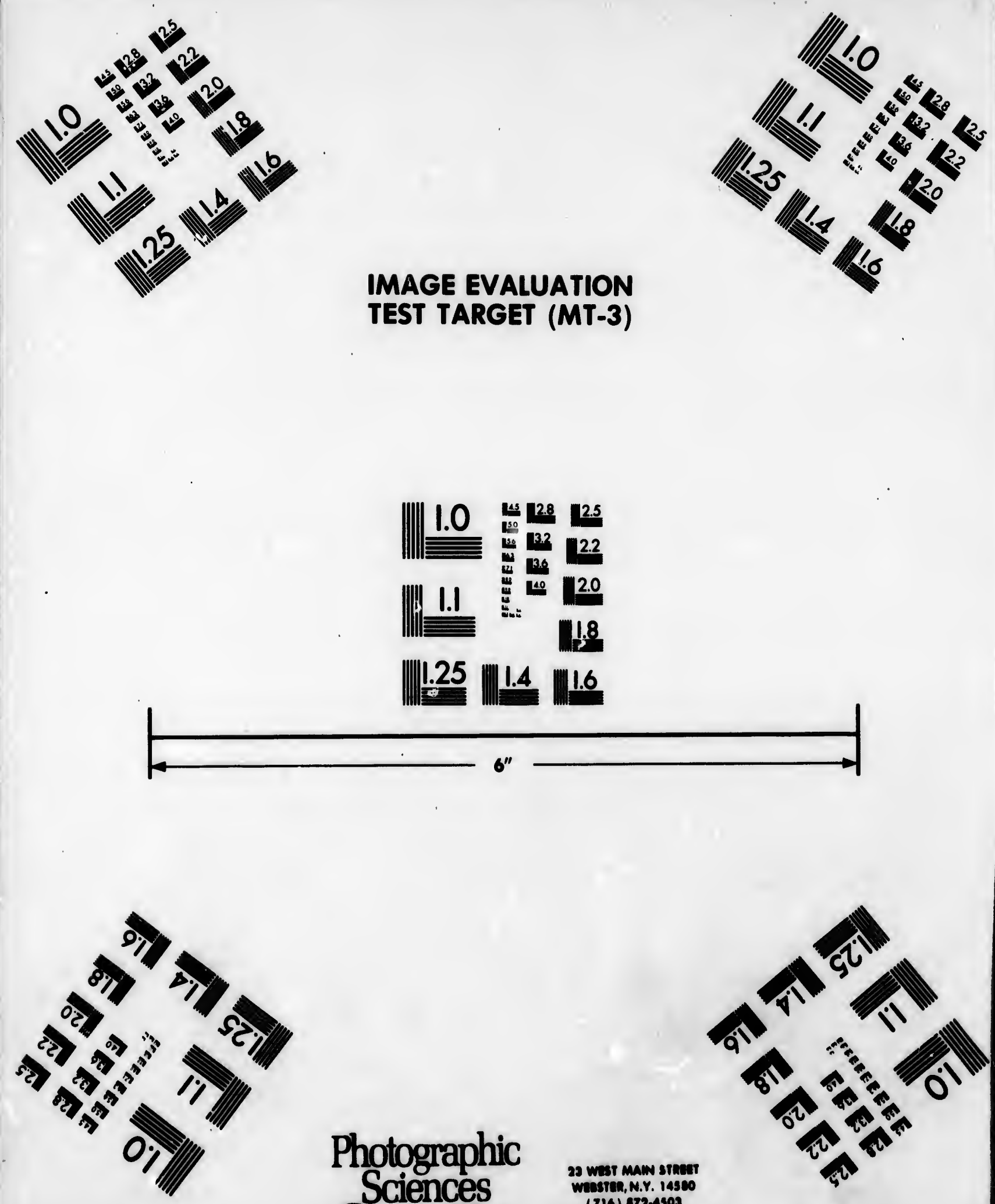

Photographic Sciences

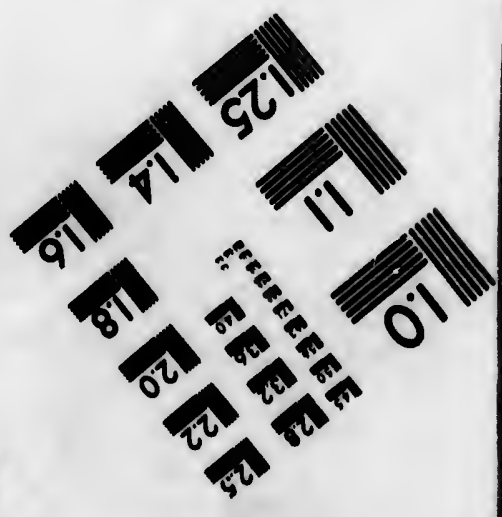
Corporation 


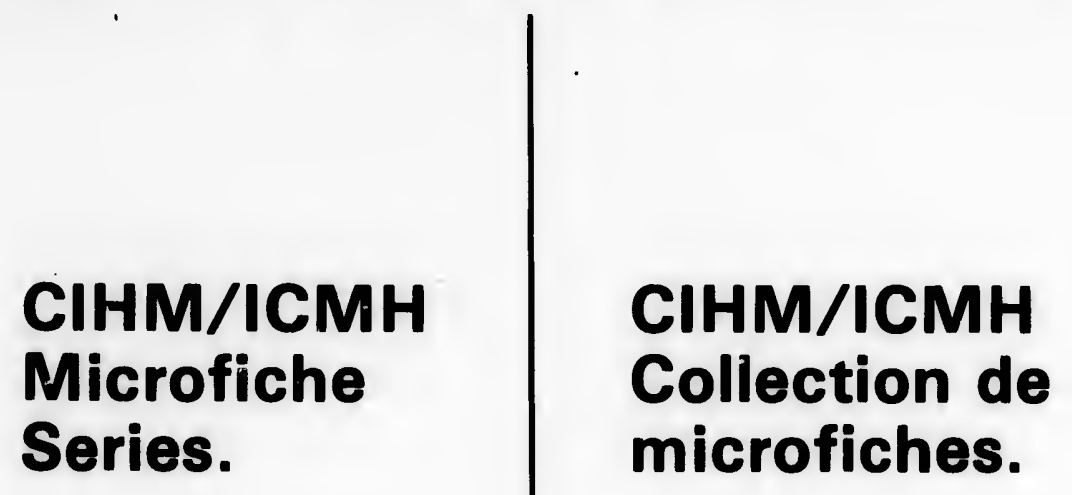

Canadian Institute for Historical Microraproductions / Institut canadion de microreproductions historiques
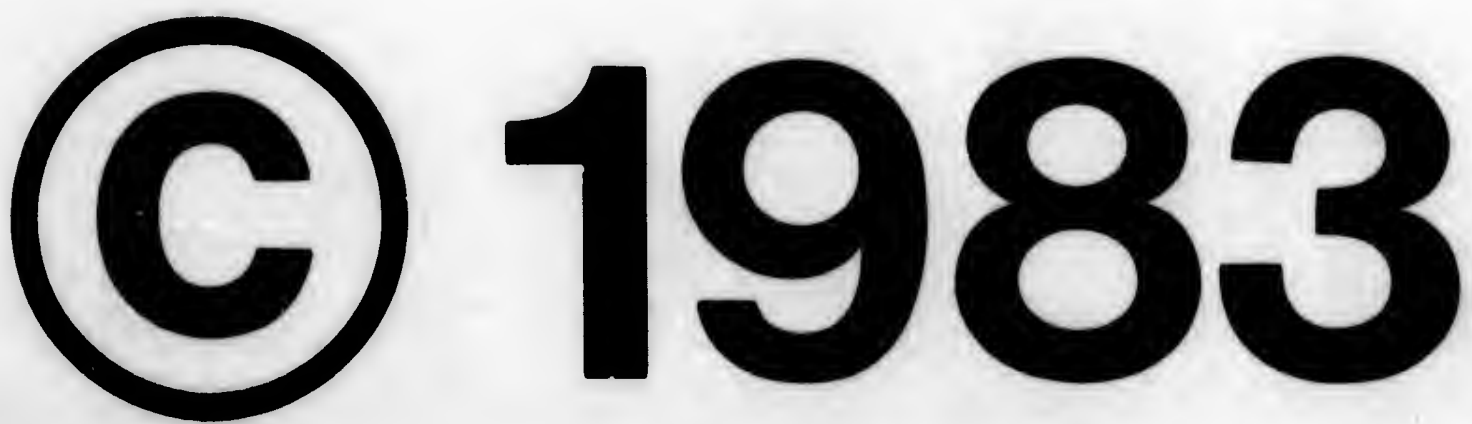
The Institute has attemptod to obtain the beat original copy avallable for filming. Foatures of this copy which may be blbliographically uniqua. which may aiter any of the images in the reproduction, or which may signiflcantly change the usual mothod of filming, are checked bolow.

Coloured covers/

Couverture de coulour

\section{Covers damagod/}

Couverture endommagle

Covers reatored and/or laminated/

Couvarture restaurce ot/ou pelliculie

Cover title missing/

Le titre de couverture menque

\section{Coloured maps/}

Cortes gcographiques on coulaur

Coloured ink (1.e. other than blue or black)/ Encre de coulour (I.e. autre que blowe ou noire)

Coloured plates and/or lllustrationa/

Planches ot/ou Illustrations on coulour

Bound with other matorial/

Rello avec d'eutres documents

Tight binding moy cause shadows of dlotortion along Intorlor margin/

La rellure serre pout eauser de l'ombre ou de la distortion lo long do is marge intérloure

Blank looves addod during restoration moy eppear within the toxt. Whenever posalble, thees hav been omitted from filming/

II ee pout que cortainee pages blanches eloutces lors d'une restauration apparalesent dans le toxto. maib, loreque cole stait peselbib, ces pagee n'ont pees sits filmises.
L'Inatitut a microflimo to malliour exemplaire qu'll lul a oto posalble do 80 procurer. Les dotails de cot exemplalre qui sont pout-stre uniques du polnt de vue blbllographlque, qul pouvent modifler une Image reprodulte, ou qul pouvent exiger une modification dans is móthode normale de filmage sont Indlquise ol-dessous.

Coloured pagea/

Pages de coulour

Pages damayed/

Pages endommagese

Pages reatored and/or laminated/

Pages reataurbee ot/ou polliculbes

Pagea discoloured, atalned or foxed/

Pages dicolories, techoties ou plqubes

\section{Pages dotached/}

Poges dotochces

Showthrough/

Tranaporence

Quality of print variea/

Quallit incrale do l'Impreasion

Inoludes supplomentary material

Comprend du motóriel euppiómentaire

\section{Only edition avallable/}

Eoulo Soltiton diaponiblo

Pages wholly or partially obecured by errata sllpo, tlasues, otc., have been refllmed to ensure the bect poselble imsed Les pares totaloment ou partiolloment obecuroles par un foulllet d'erreta, une polure. eto.. ont cíl fllimces a nouvesu do tagon obtenir la mollibure image poselblo.

Th
po
of
flir
Or
bo
th
sid
ot
fir
sio
or

Th

$$
\text { Tily }
$$

$$
\text { wh }
$$

\section{Mo}

$$
\text { bot }
$$

$$
\text { rig }
$$$$
\text { rec }
$$ 
The copy filmed here has been reproduced thanks to the generosity of:

\section{Netional Library of Canada}

The Images appearing here are the beat quality possible considering the condition and lagibility of the original copy and in keoping with the filming contract speciflcations.

Original coples in printed paper covers are filmed beginning with the front cover and ending on the last pege with a printed or illuatrated impresslon, or the back cover when appropriate. All other original coples are fllmed beginning on the first page with a printed or illustrated impression, and ending on the last page with a printed or illustreted impression.

The last recorded frame on eech microflche shall contain the symbol $\longrightarrow$ Imeaning "CONTINUED"), or the symbol $\nabla$ (meaning "END"), whichover applles.

Maps, plates, charts, otc., may be filmod at difforent reduction ratlos. Those too large to be entirely included in one exposure are filmed beginning in the upper loft hand cornor, loft to right and top to bottom, es many frames as required. The following dlagrams illustrate the mothod:
L'exemplaire filmo fut reprodult grace a la gónórositó da:

Blbliothæque nationala du Canada

Les imeges sulvantes ont 6té reproduites avec lo plus grand soin, compte tenu de la condition at de la nettetó de l'exemplaire films, et en conformite avec les conditions du contrat de fllmage.

Les exemplaires originaux dont la couverture en papier est imprimbe sont filmbs en commençant par lo premier plat et en terminant solt par la derniere pege qul comporte une empreinte d'impresslon ou d'illustration, soit per le second plat, selon lo cas. Tous los autres exemplaires originaux sont filmés on commençent par la premiàre page qui comporte une emprelnte d'impression ou d'illustration ot en terminent par la dernilore page qui comporte une telle empreinte.

Un des symboles suivents apparaittra sur la dernlore image de cheque microfiche, selon le cas: le symbole $\rightarrow$ signifie "A SUIVRE", le symbole $\nabla$ signifie "FIN".

Les cartes, plenches, tableaux, etc., peuvent dire filmbs des taux de róduction diffórents.

Loreque le document est trop grand pour stre reprodult on un soul cllchs, II eat fllms partir de l'angle supórieur gauche, de gauche drolte, of do haut on bas, on prenant lo nombre d'Images nócessaire. Les diagrammes suivants Illustrent la mothode.
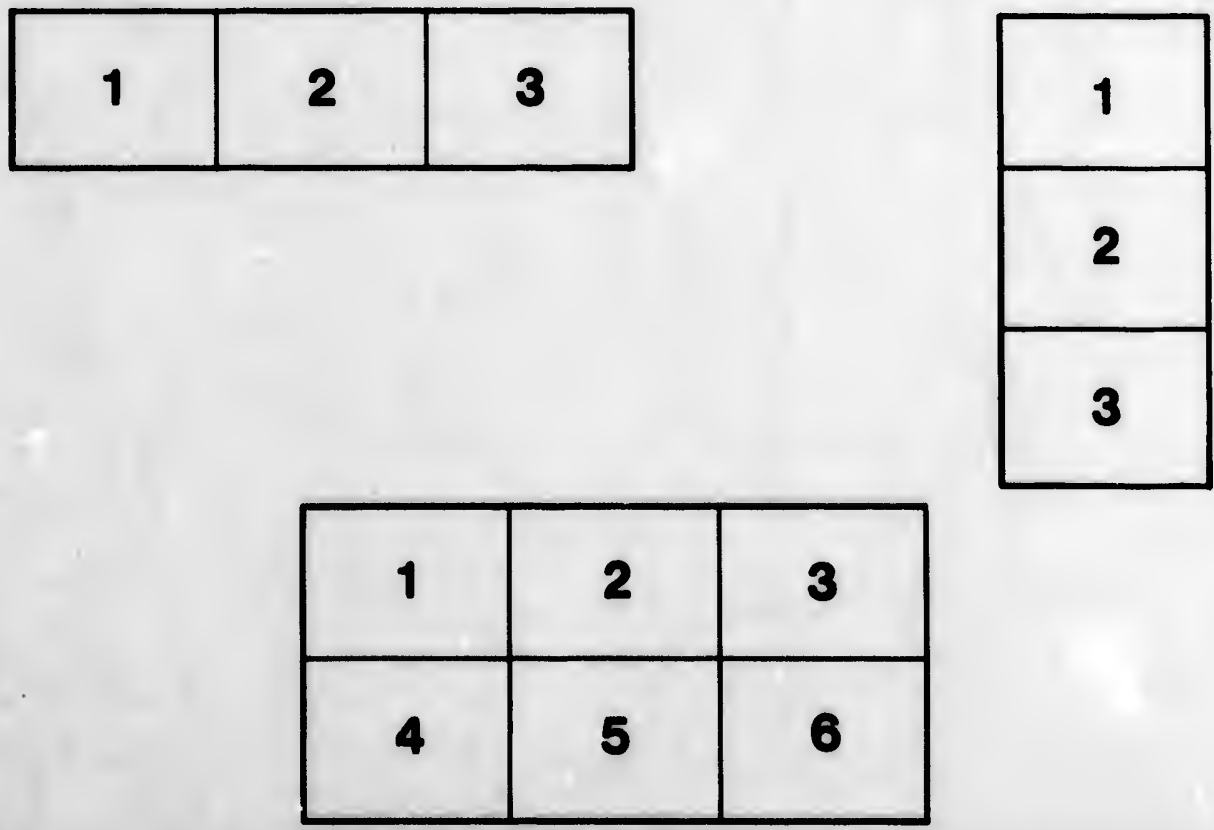

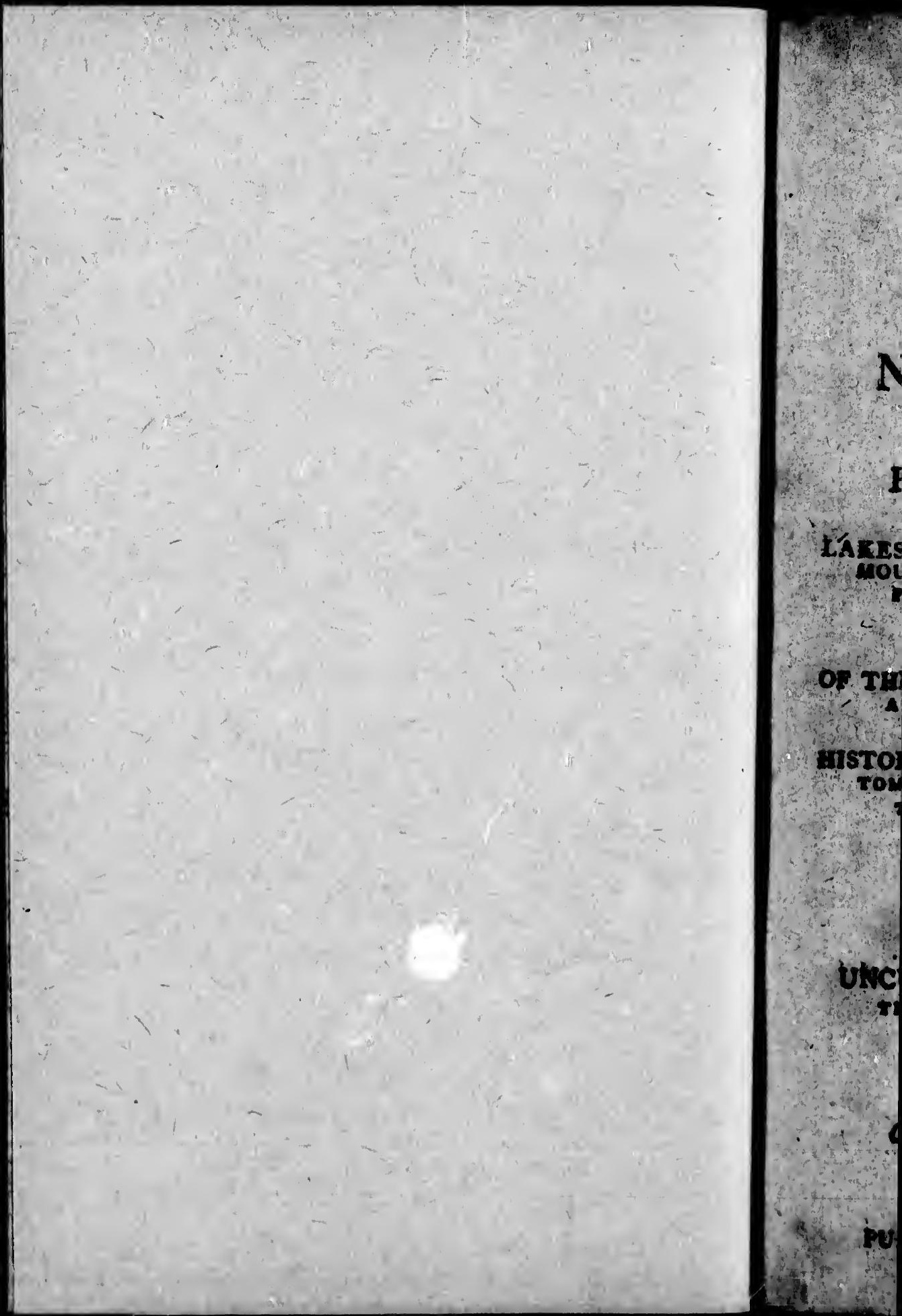
ruth resio

TRAVELS

TBOUGBOdT TUE

INTARIOR PABTS

6*

NORTH AMERICA,

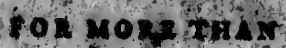

FIVE THOUSAND MILES,

copreutho An A ccovur br TH

LATES, ISL WDS AND RIVERS, CATERACTS, MOUNTAINE, MINER ALS. SOLL AND VEOKTABSE

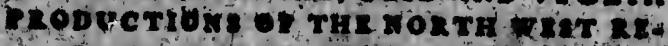

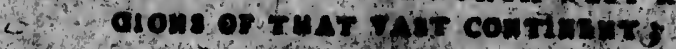

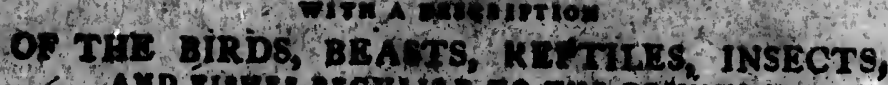

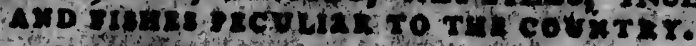

- Holthl e wirn a conctos

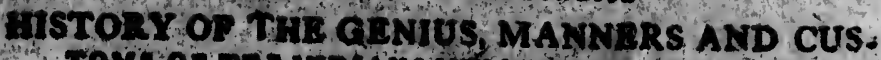

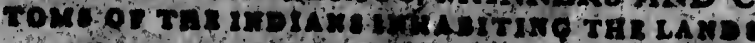

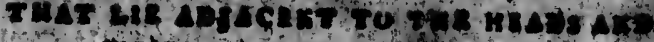

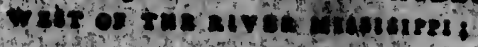

$$
\text { APPENDIK, }
$$

meervative tris

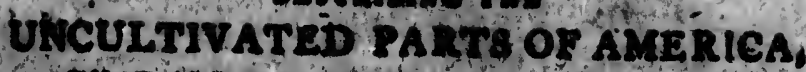

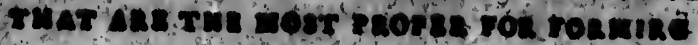

$$
\text { 82012LMNIS }
$$

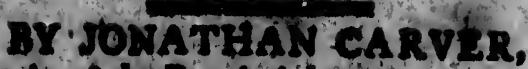

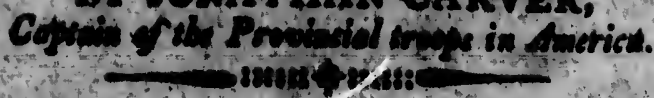

WAPOOLE, N.

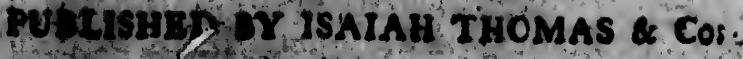




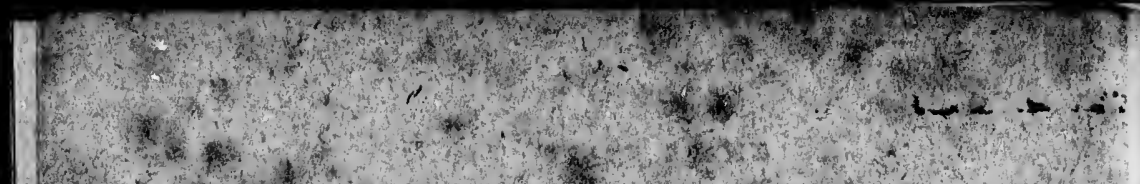

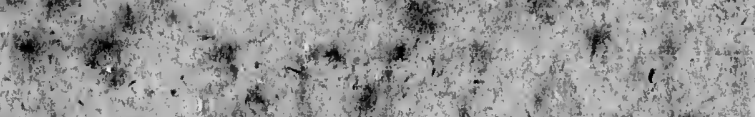

ax

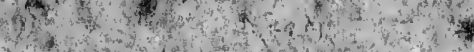

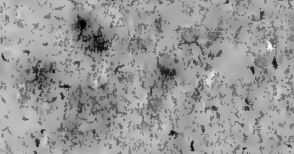

*

$a^{2}$

-

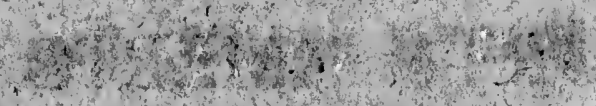

$$
\rightarrow
$$

$$
1
$$

I

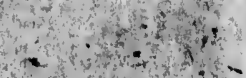

8t:

$+1$

$$
\frac{1}{2}+2
$$

$$
\text { an } \operatorname{lin}^{2}
$$

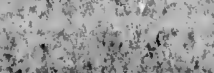

\section{2.t.}

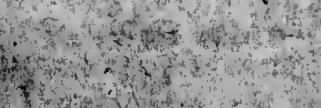

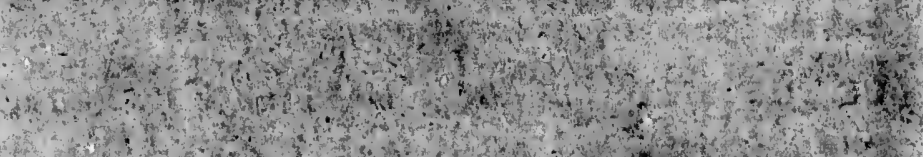

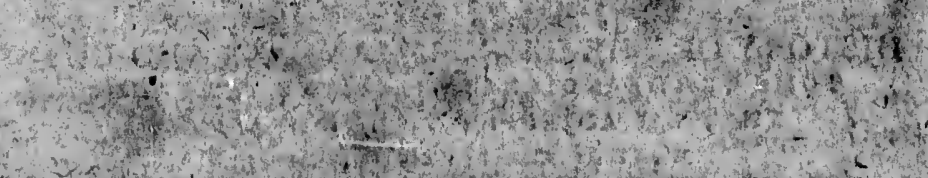

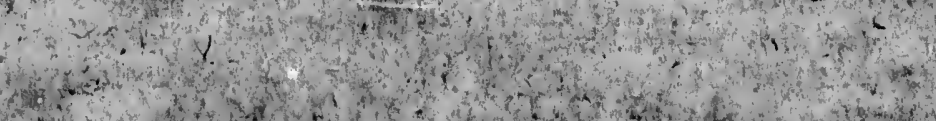

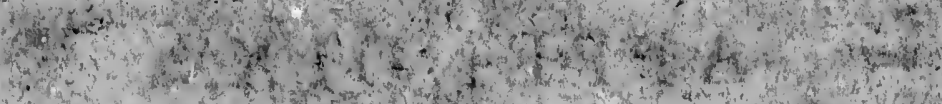

$$
\text { The } 12 \text { ind }
$$
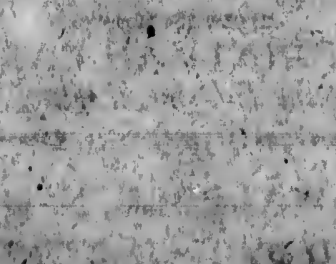

31

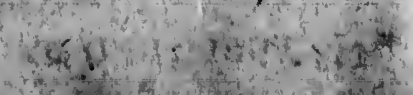




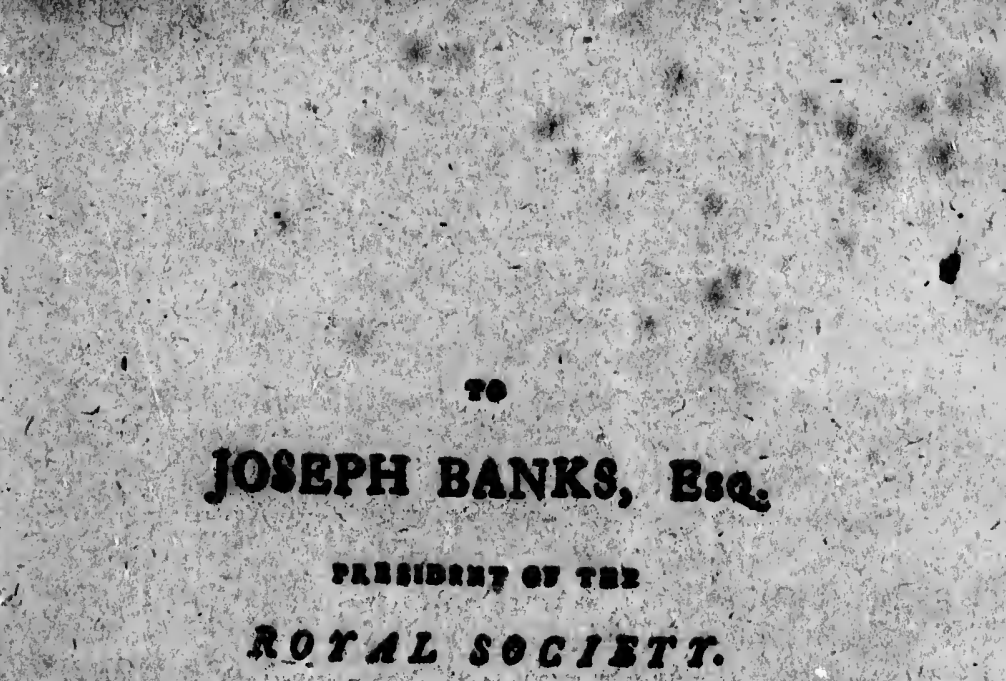

\section{IB,}

W

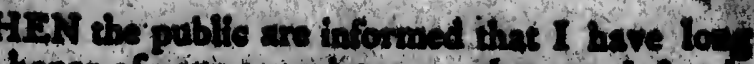

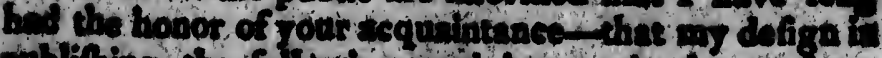

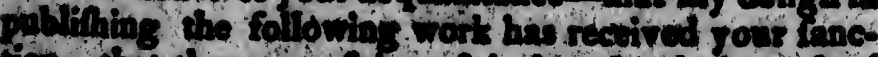

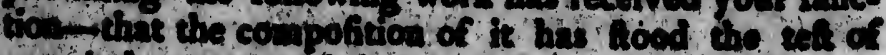

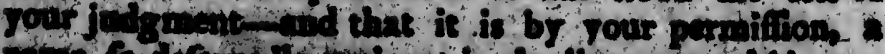

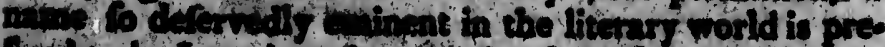

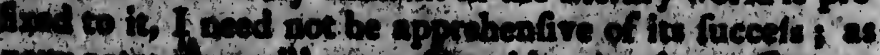

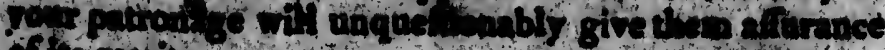
of tomentis

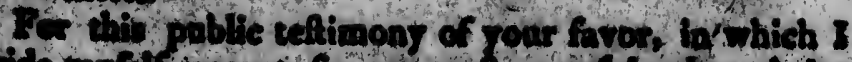

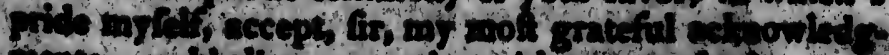

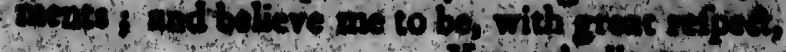

\section{Your obediuts}

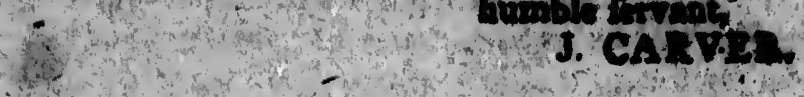

n.t.

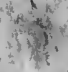




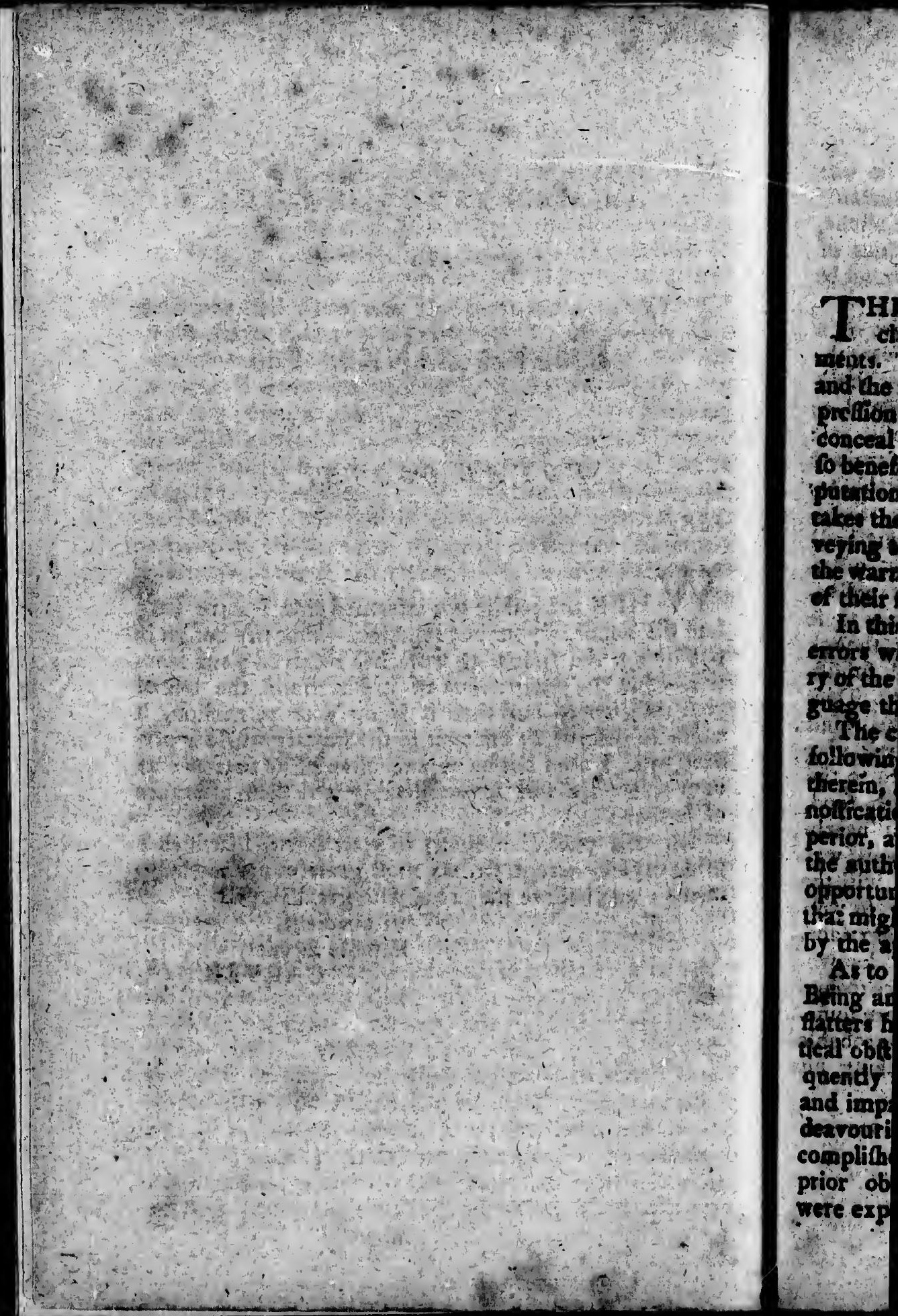




\section{AN ADDRESS TO THE RUBLIC.

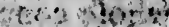

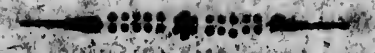

THE faromble resoption thic work has met with,

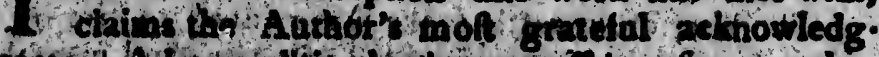

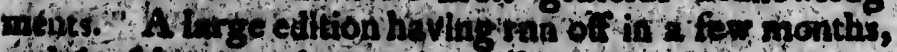

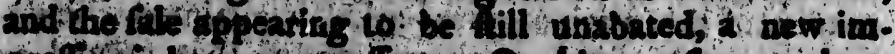

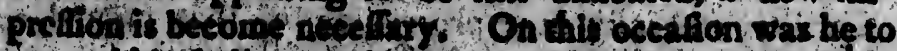

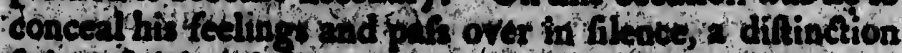

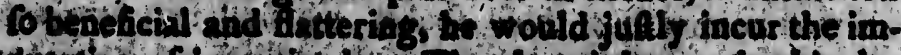

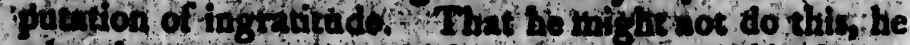

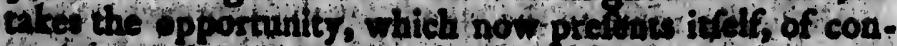

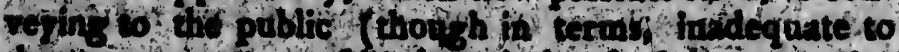

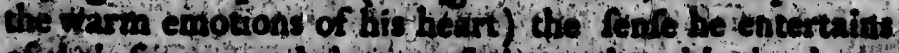

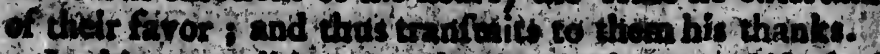

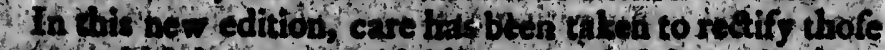

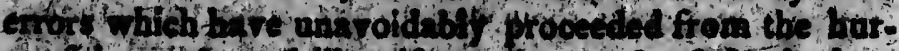

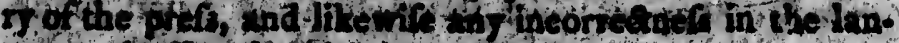

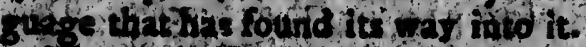

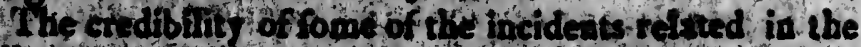

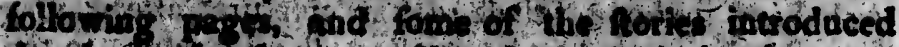

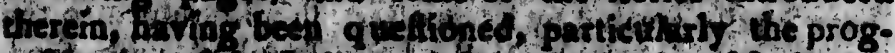

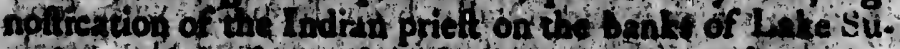

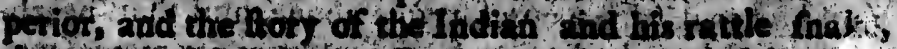

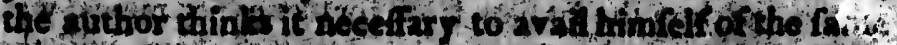

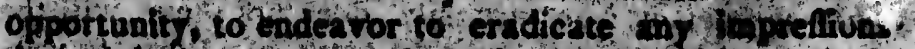

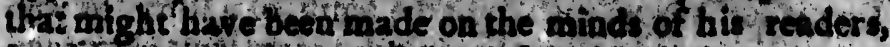

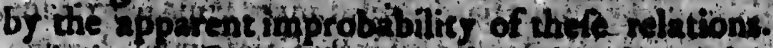

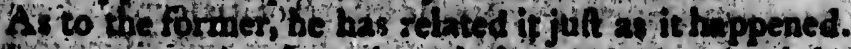
Bung an bro withers to the thole tranketion (rod, be

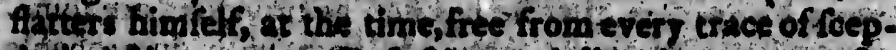

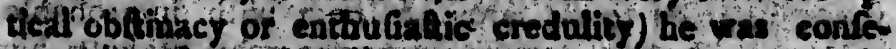

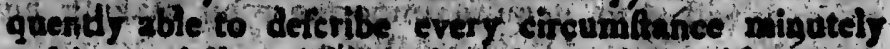
and imparially, Ithis he her doge $\&$ but wittotit on. desvotring to account for the means by which it was accomplithed. Whether the prediction yas the refult of prior obfervations, from wbich certain codifequences vere expeted to follow by the fagacions priel, and the 42 


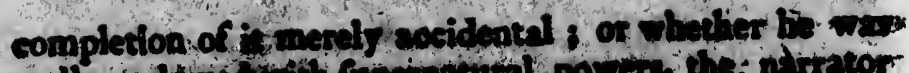

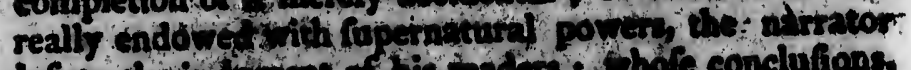

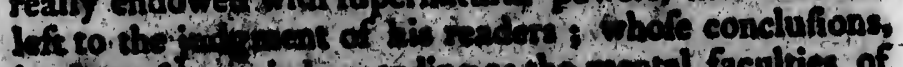

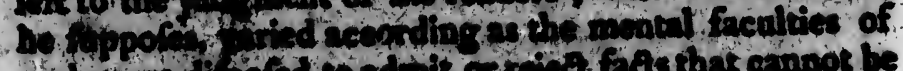

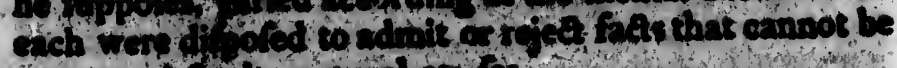

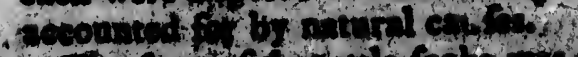

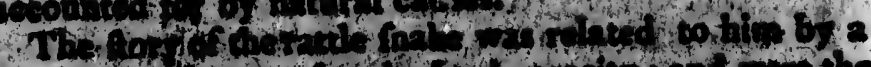

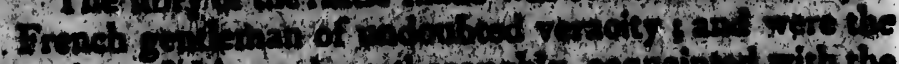

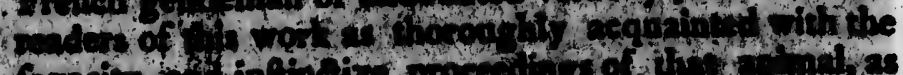

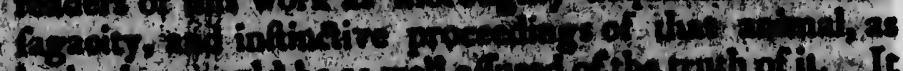

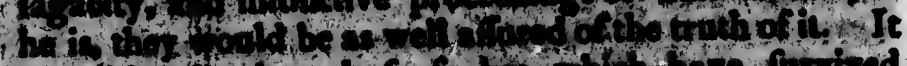

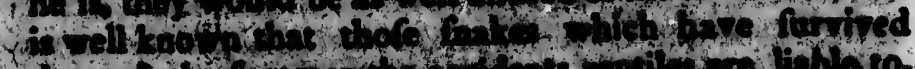

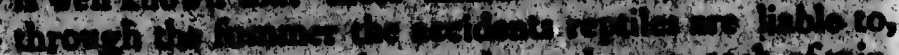

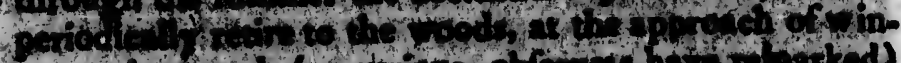

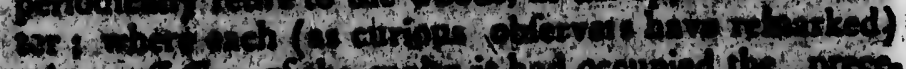

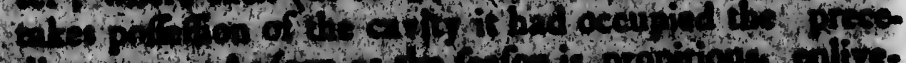

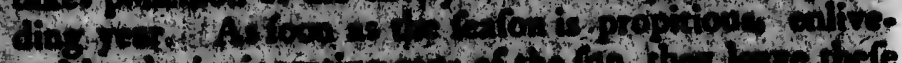

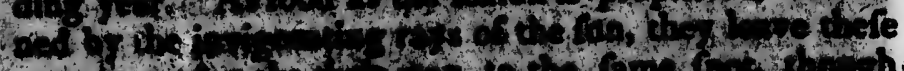

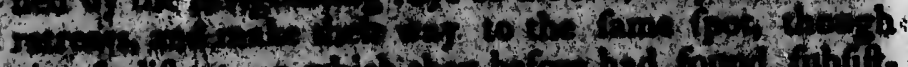

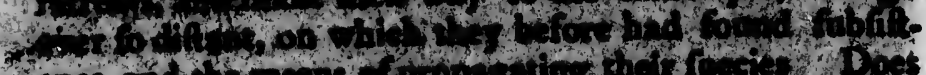

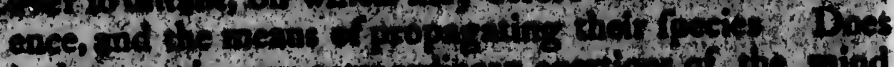

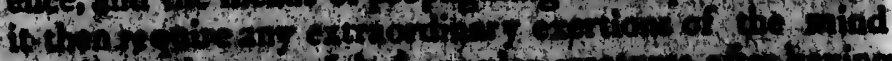

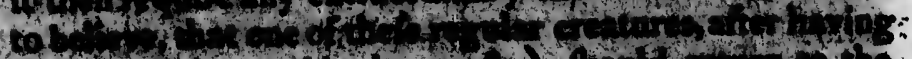

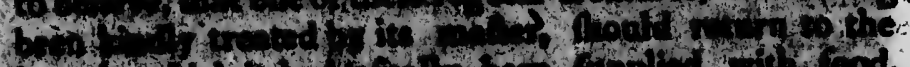

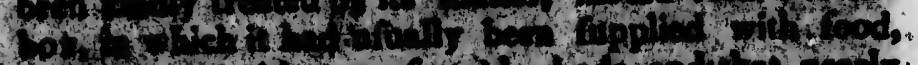

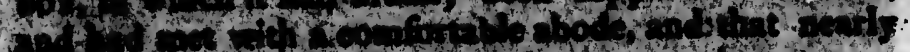

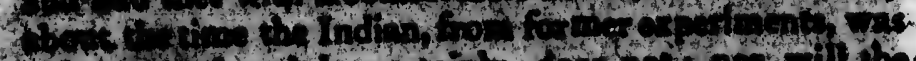

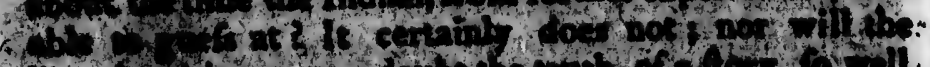

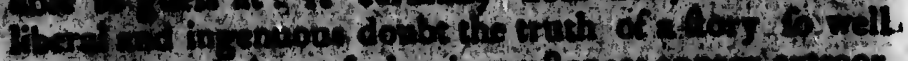

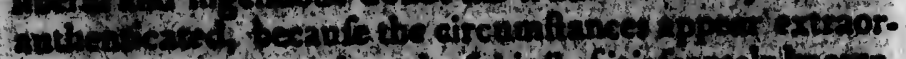

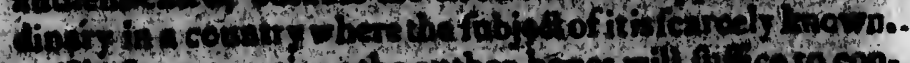

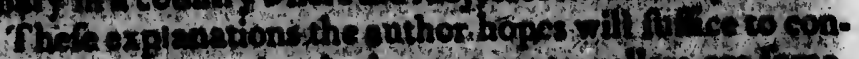

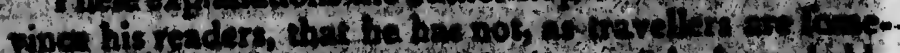

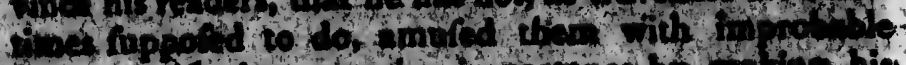

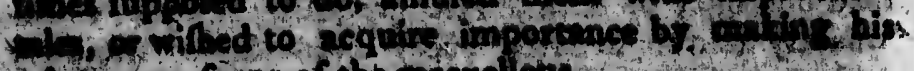

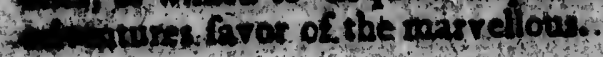

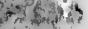
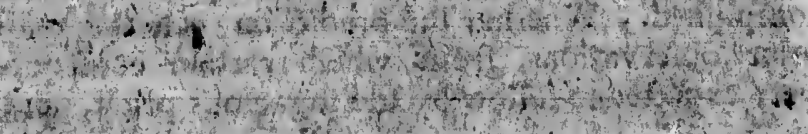

cthe 


\section{ati \\ 12 \\ CONTENTS.}

w $x$ -

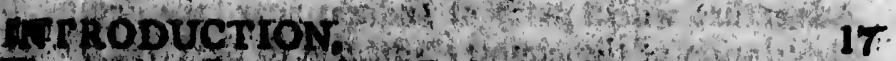

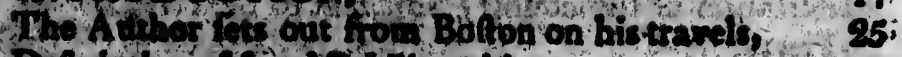

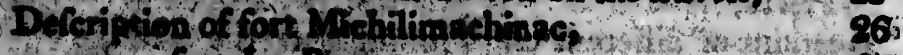

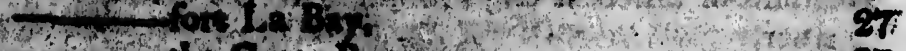

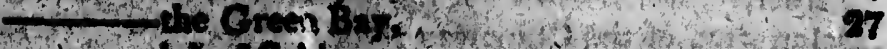

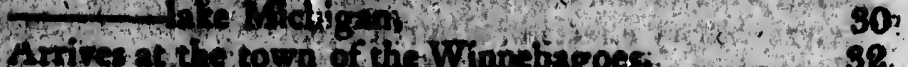

-

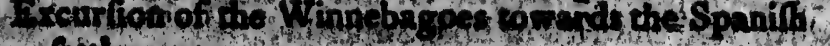

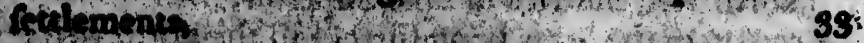

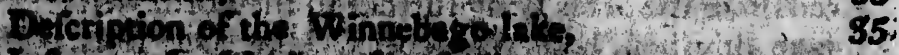

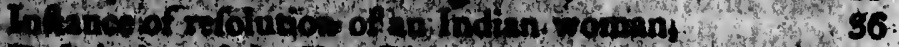

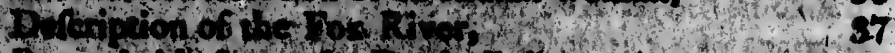

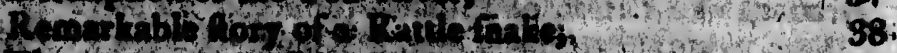

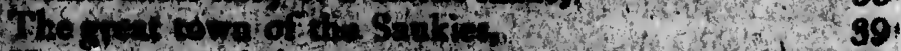

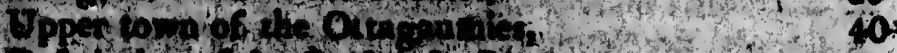

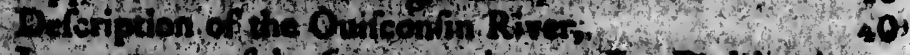

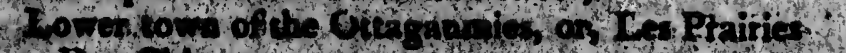

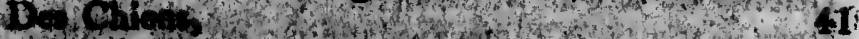

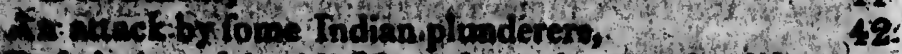

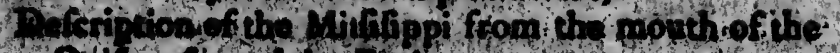

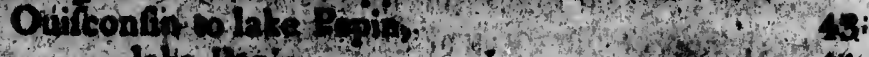

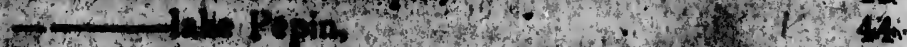

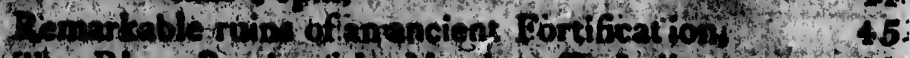

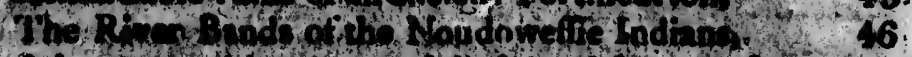

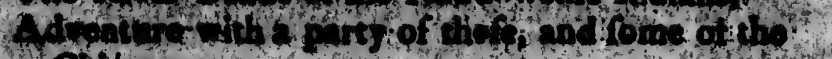

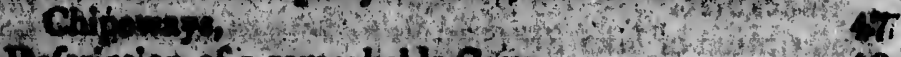

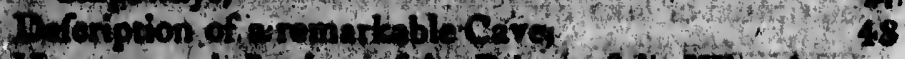

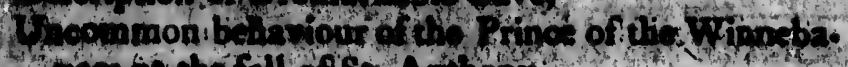

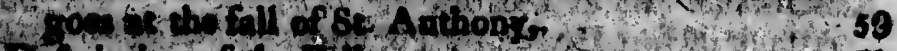

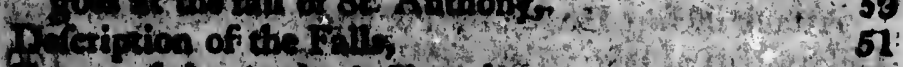

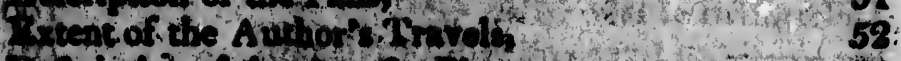

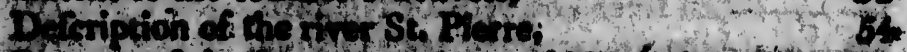

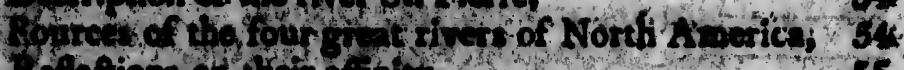

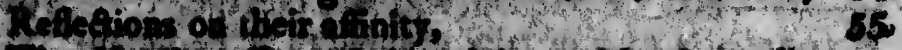

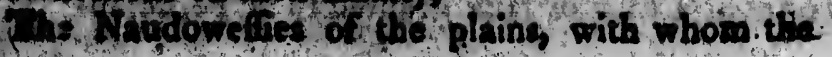


viit.

\section{contrents.}

\section{Author whicered in the yeer 1766,}

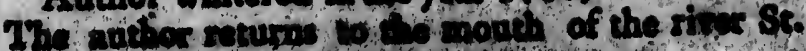

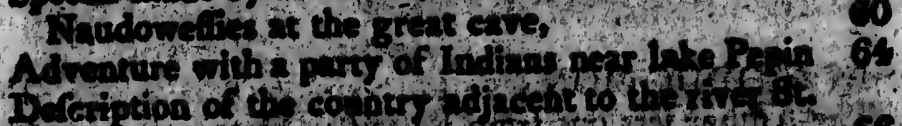

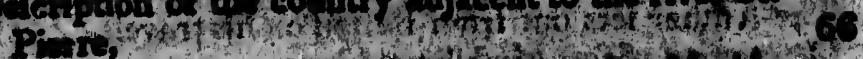

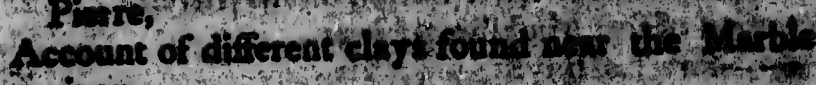
river,

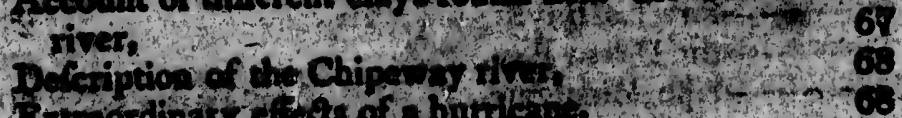

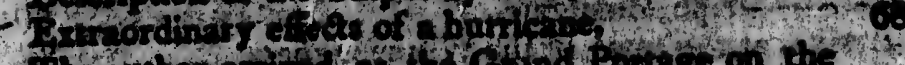

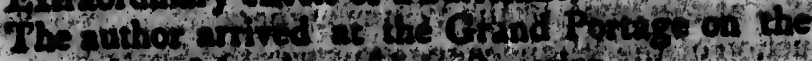

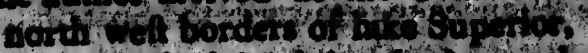

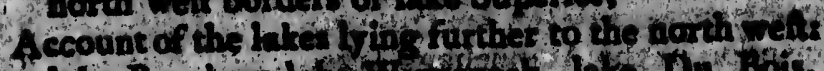
The Bonbon to the Whe la Pi

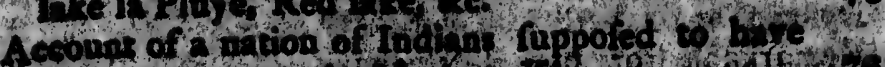

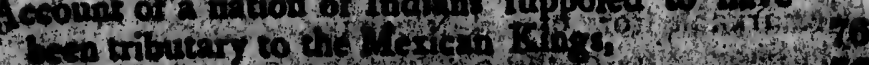
4.

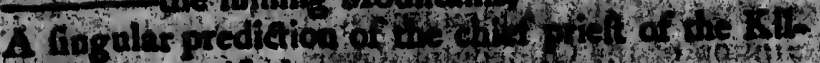

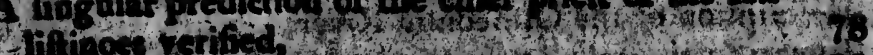
Decin or ont

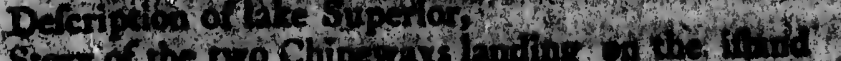

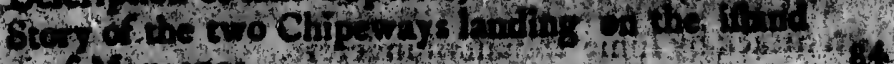

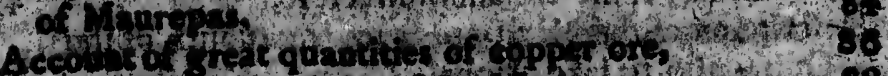

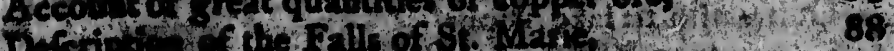

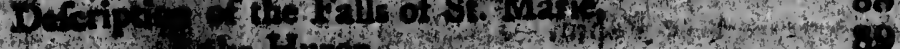

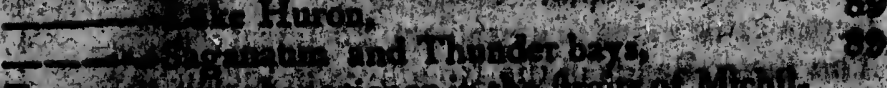
W.

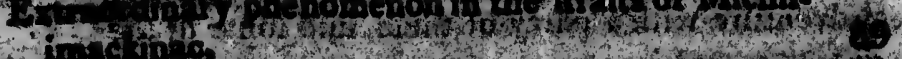

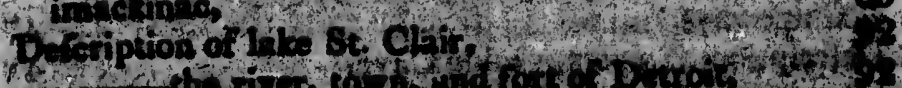

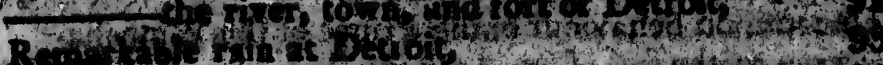

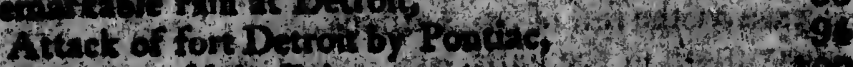
Dachiption of hls brie.

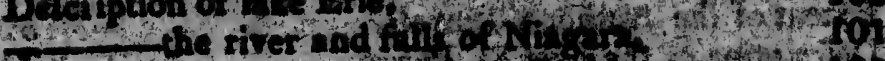

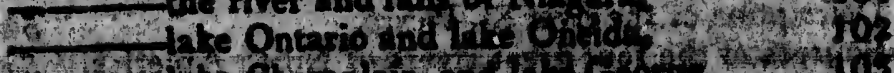

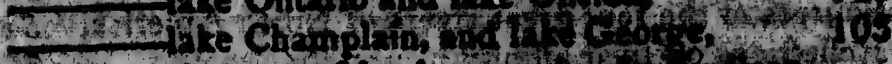

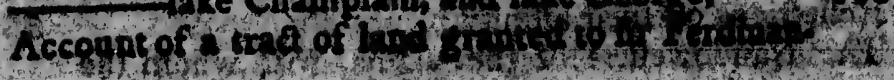




\section{cotnuns:}

if.

to Gorres and Caphin John Maron, $10 \%$

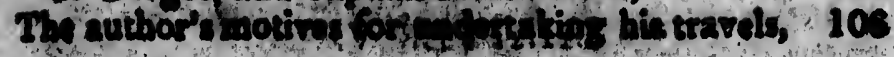

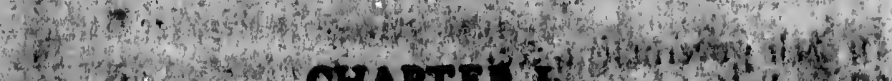

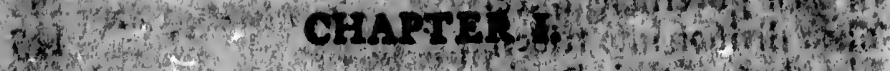

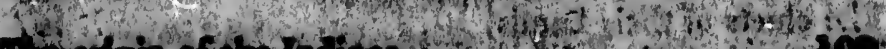

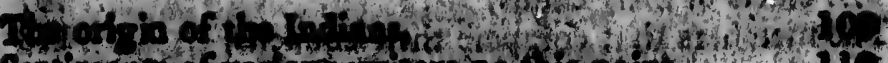

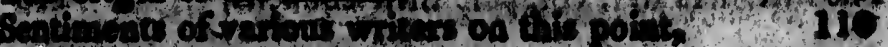

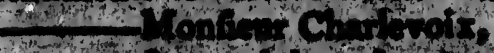

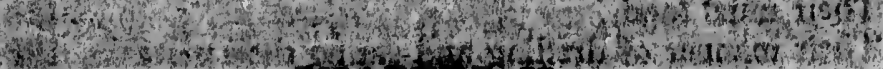
Ge

Qf

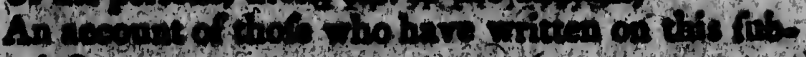

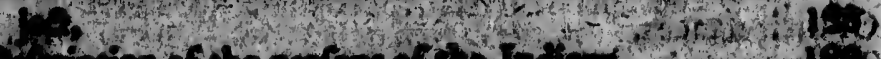

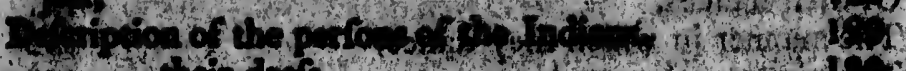

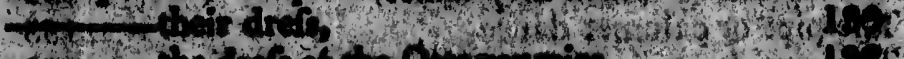

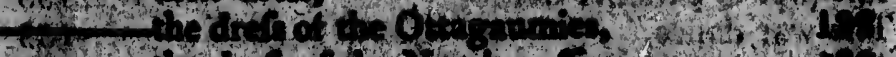

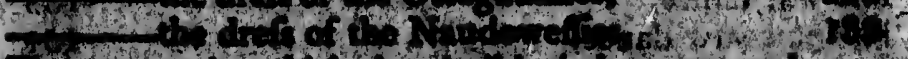
$+\infty$

1. 2.7.

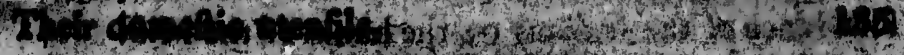

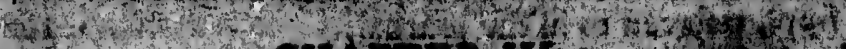

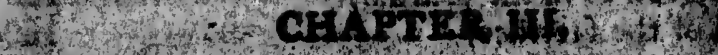

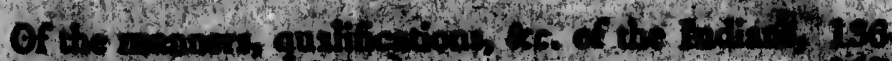

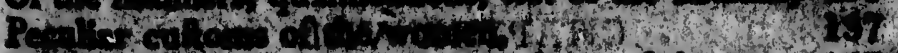

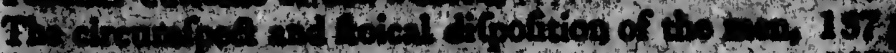

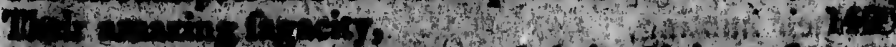

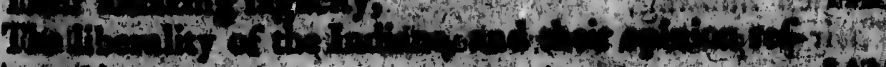

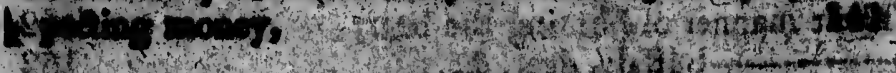
. 640 ath

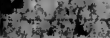

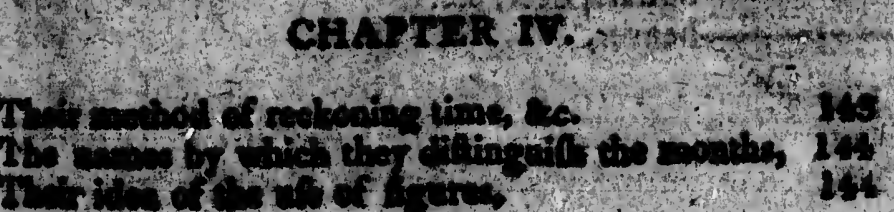


a

\section{cosingistos}

$4: 4$

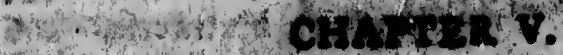

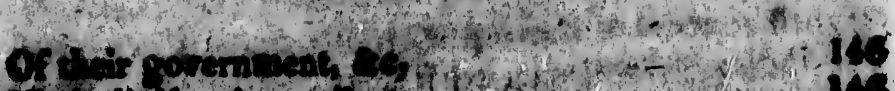

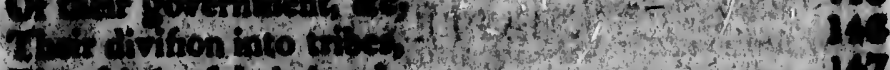

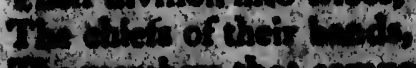

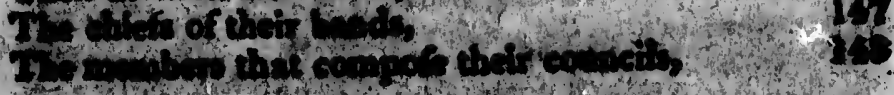

$-125$

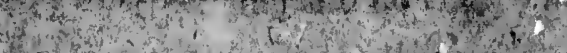

\section{chaptise VI.}

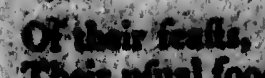

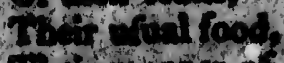

$2 y+m, y$

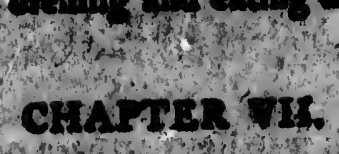

ertingthen 25 man $n$

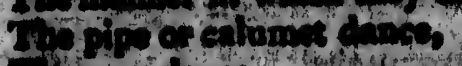
ois dones?

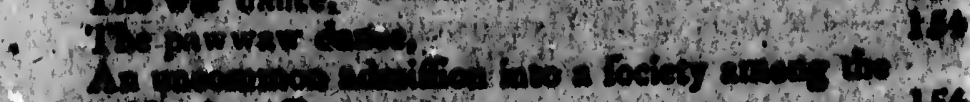
(3)

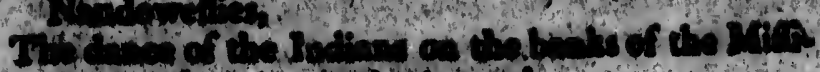

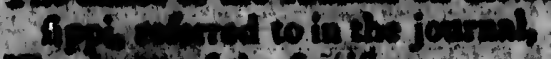

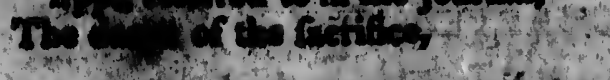

\section{crartas vel.}

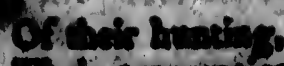

$$
\begin{aligned}
& \text { Iy }
\end{aligned}
$$

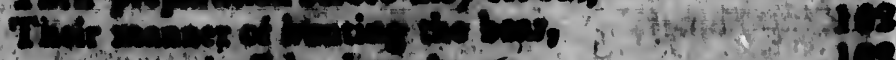

$$
\begin{aligned}
& \text { - }
\end{aligned}
$$

kis $t^{2}$

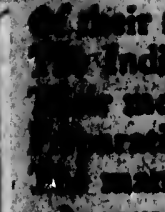

at

$x+5$,

An bila

contion

samine

ur syes

Atowingef

finte

15ivis

$2 x^{2} x^{2}$

Whation?

$\frac{1}{2}+2$

tring

that

19

sints?

hit

(entas

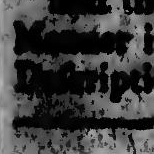




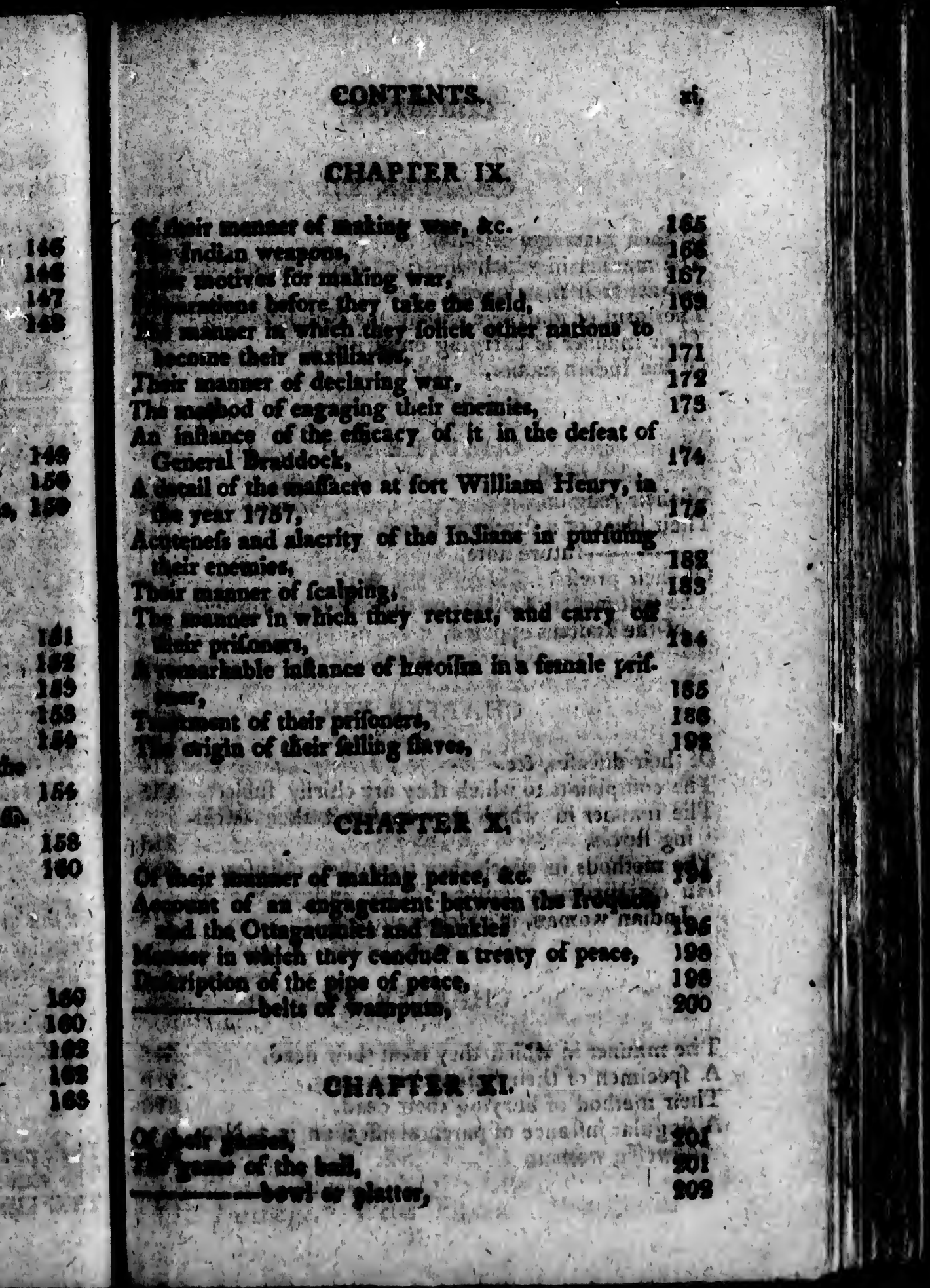




\section{chtality 4 st.}

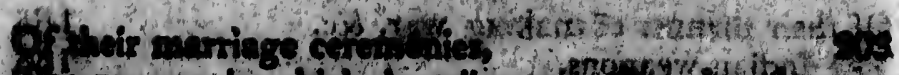

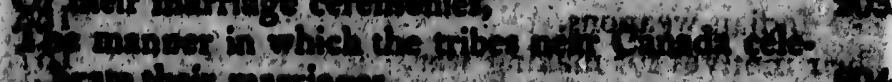

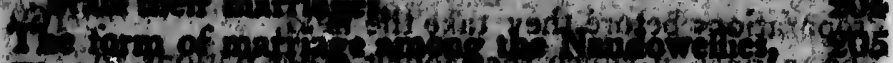

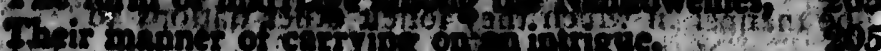
Co the Indian naver

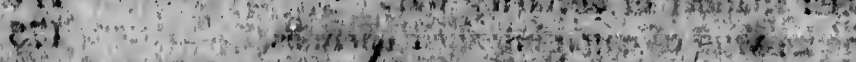

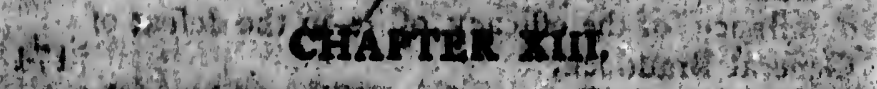

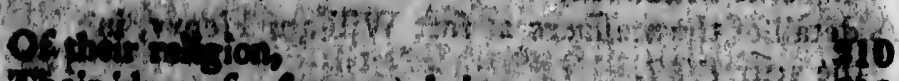

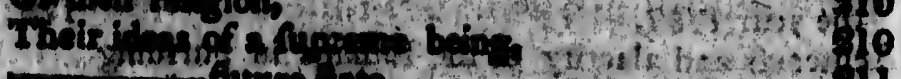

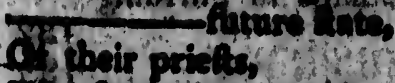

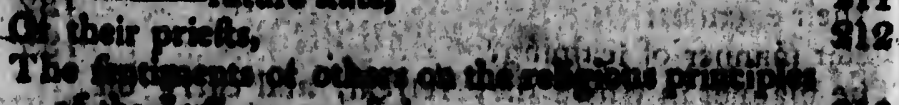

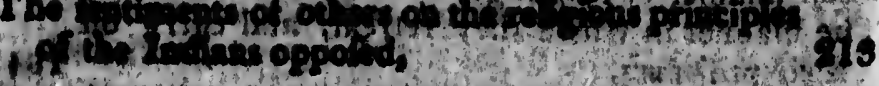

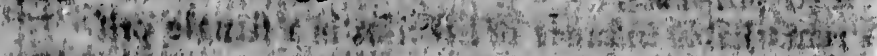

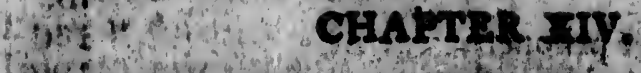

Q

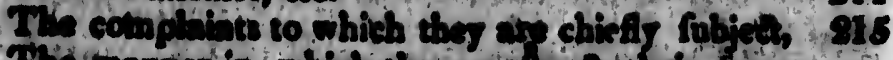

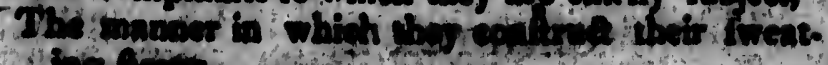
2 lon cou 210

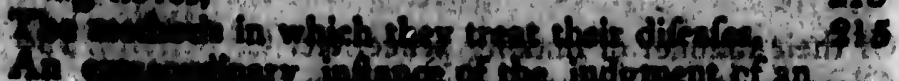
An

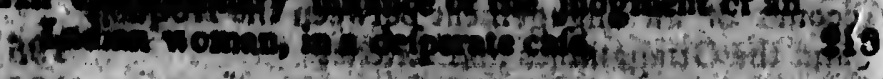

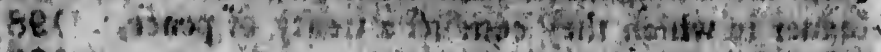
ast is:

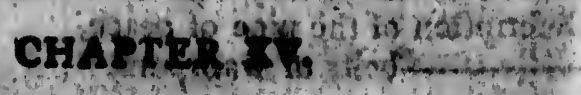

The wanter in wbick wey wat their deed,

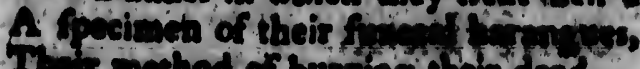
The mothod of bur ing ofhtr dewe,

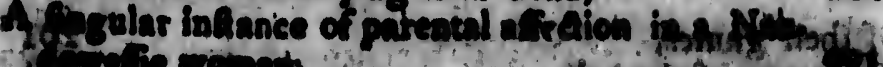
bovirife womats sot

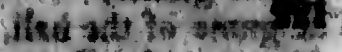

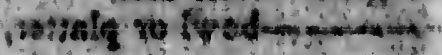

A concil Their pe Their p xions<smiles>C1=C[As]2C[As]1[As]2</smiles>

Of their Of the $C$ Duprip

tof the 1 which Aneri

The TI: The Wo Cat of t Itw 패 The 7 Th vo The Moi The Ben ( The Oth 


\section{CHAPTER IVI.}

$\cos 27$

1) 54 Iton 1 in

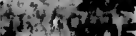
hen $\operatorname{xin} 23$ $+4$

sit

(3)

sinitis

atsits

I) th

$\therefore 26$

11

1. 12

,

240

tsestint

(undint

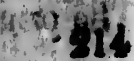

is $\$ 918$

ante.

210

sistizes

mpos

1 robists.

dextint

ing

819

819

280

modis

ntronts

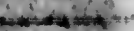

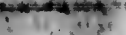


tiv.

Blue Jay. Wakon Birk,

The Black Bird Sed Bird,

The Whetrive The Bird, Llumming Bird;

The Sturgeon

The Cat fll. Carp. Cheb,

The Bu

Ithe til

\section{SERRENTE}

The Routh Snake,

The Lon's Black Snake. Strifed or Garter Snake.

- Water Eanke. Ittong Sanke. Green Sanke, 250

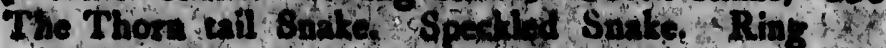

Sathe Two heddat Salk Tottoif or had Tinh

21

IzARDS.

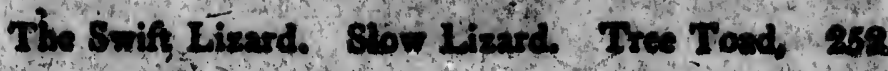
mezcts of th thot 16

ats?

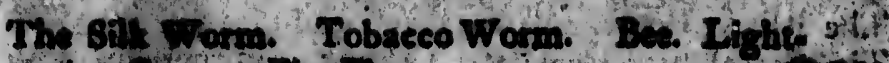

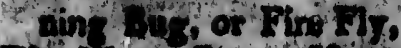

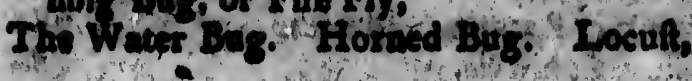

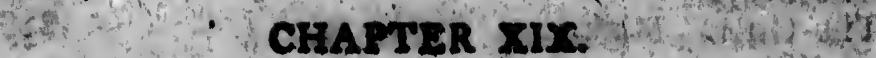

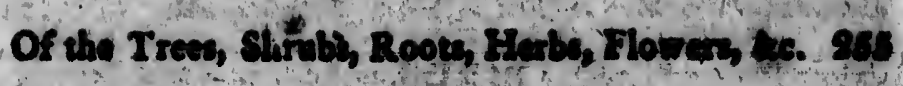

Spikens Sartup Solomic

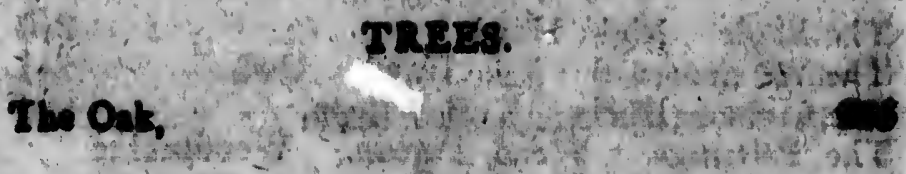

The w

The P. tolde

The sh The. Gie Crinbe Anting

Sanicl Inome 
The Pine Tree, Maple. Aft, 256 The Hemlock Tree. Bafs or White Wood Wick-, pick, or suckwict Butron Wood;

\section{Ner TRITS}

The Butter, or Oil Nat. Beech Nat. Psean Nut, 258 The thekeryi.

TRUIT TRDES.

The Vine, +43, whis

The Mulbur Tre Crab Apple Tree PAro

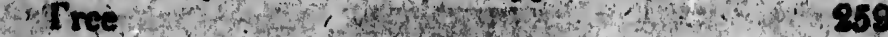

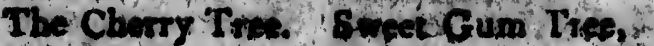
201

a

280

The Willows Bhis thad surafies.

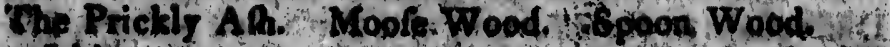

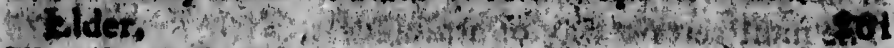

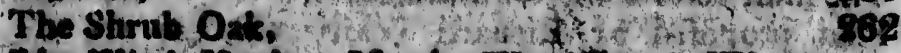
The Wich flate. Mrule Wat tree Wiater Greva. Tever Buda,

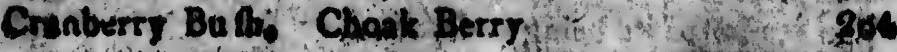

\section{RoOTS AND BUANIS.}

Evilounar.

Saripprilla. Ginfang. Goldthread. 265 Solomoa's Seal. Devil's Bits Bloud Root, - 256 


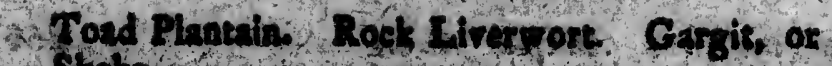

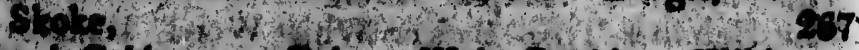

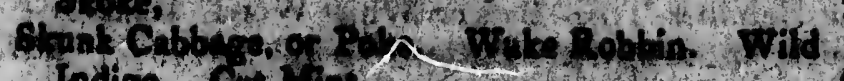

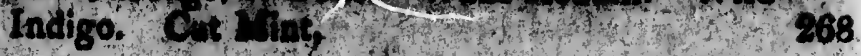

\section{WOWERS.}

W.

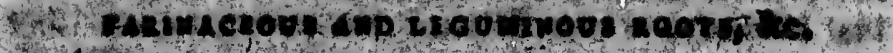

\section{Aty ar Itdime Cora.}

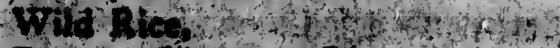

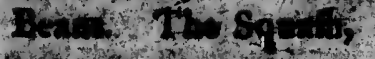

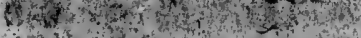

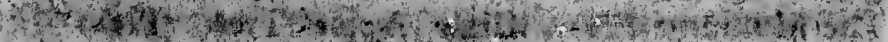

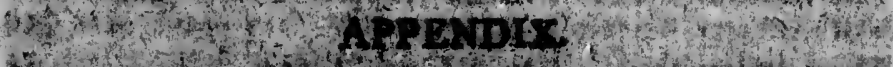

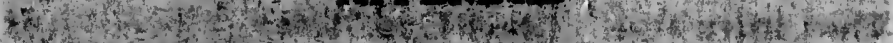

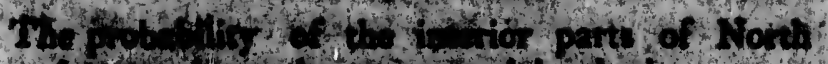

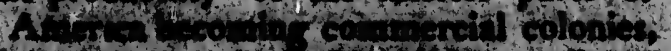

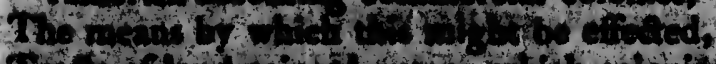

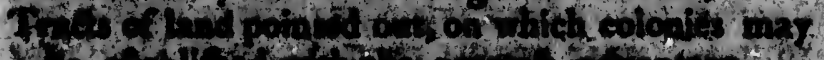

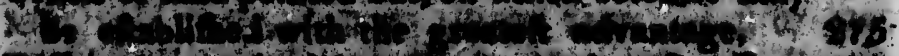

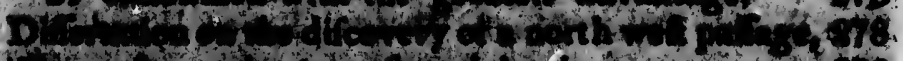
H.m.

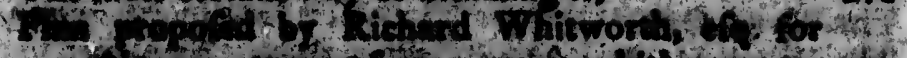

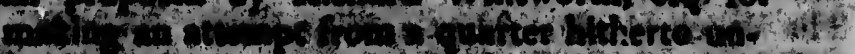

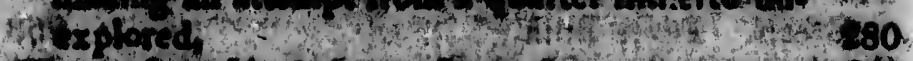

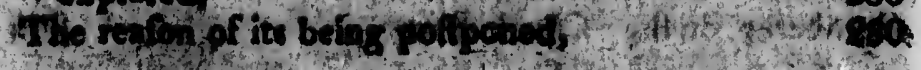

ait.

$$
13+2+\frac{a}{2}+2+x+1
$$

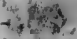

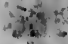




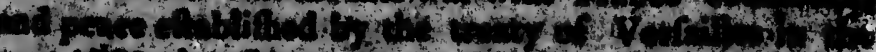

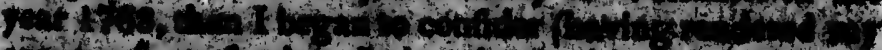

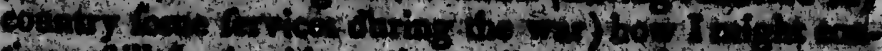

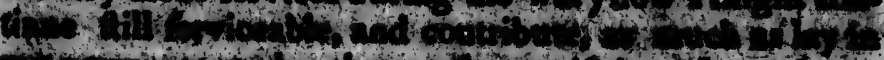

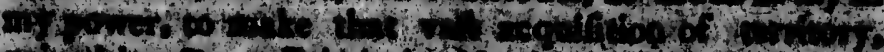

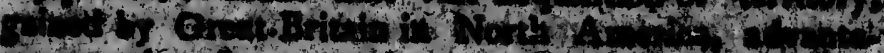

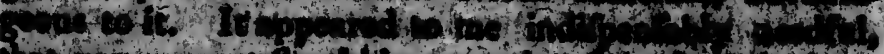

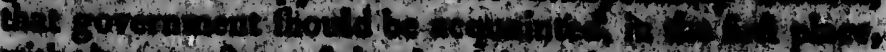

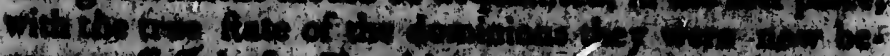

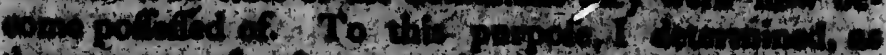

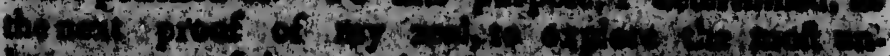

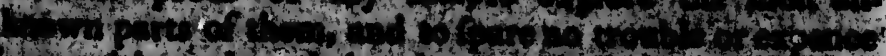

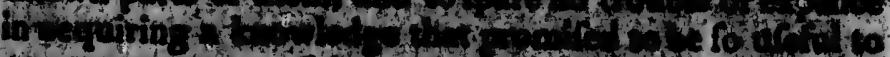

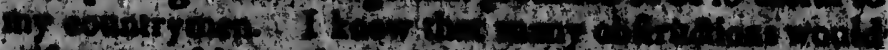

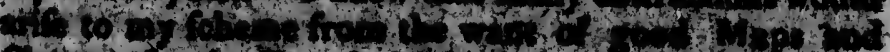
A t

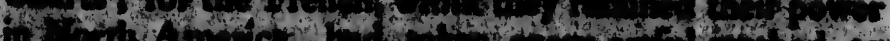

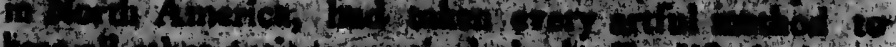

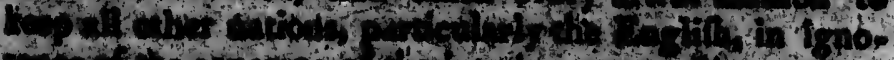

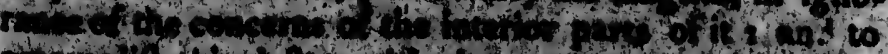

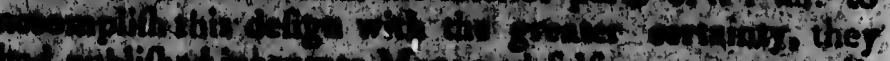

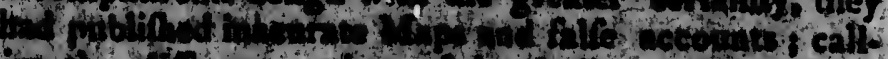

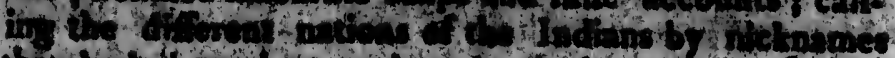

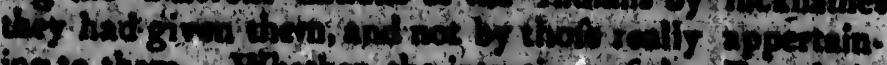

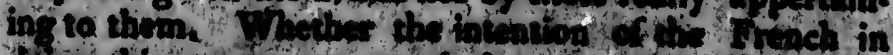

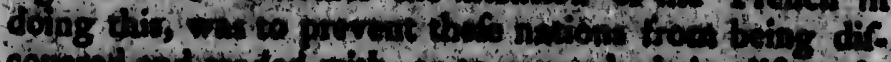

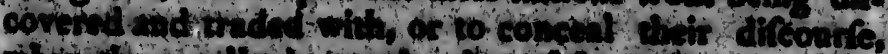

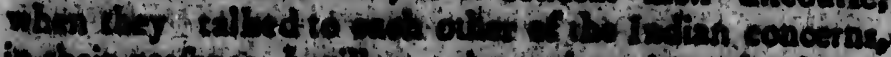

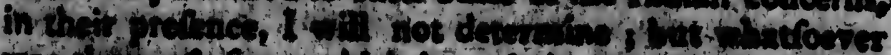

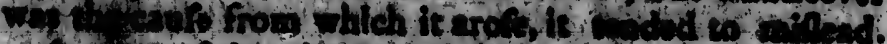

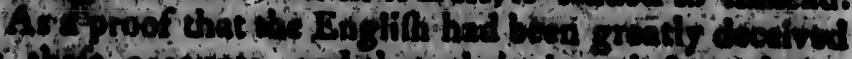

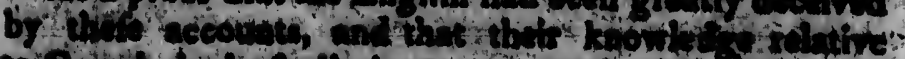

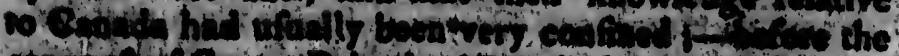

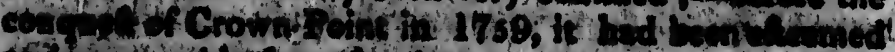

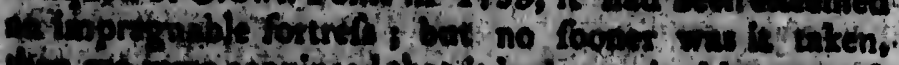

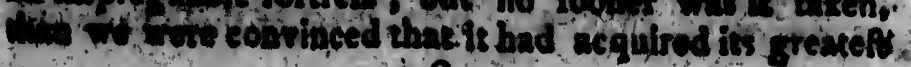
- 2 
fecurity from fulcerepors, given ous by its polteflors and ungle ha $\mathrm{r}$ beth bothed dow with a few four

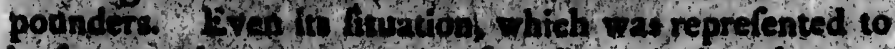
be fo ver d d pht 8 thes was faund to owe its advants.

(5) ges to the fine fource, It canvot be detied but that

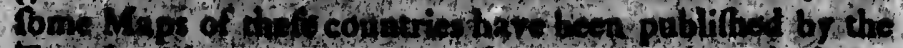

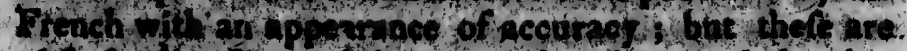

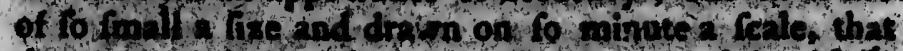

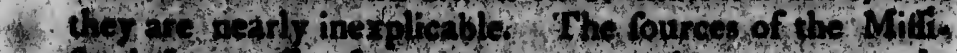

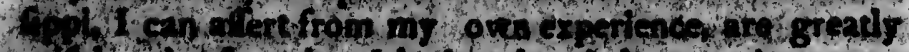

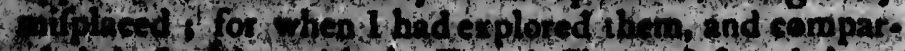

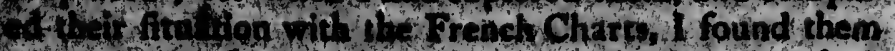

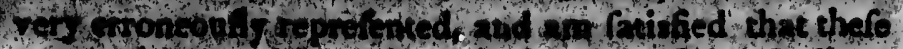
wero o 1 copied tom the rude Retches of the Inclions.

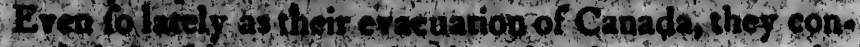
unued bat fohem to dective leaviog no traces by

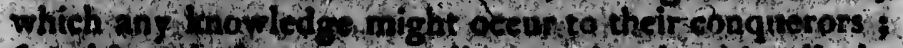
for lithor th thes were mell arquainsed with all the

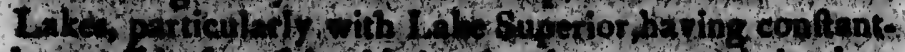

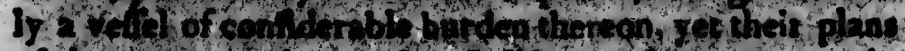

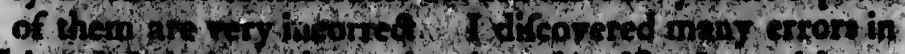

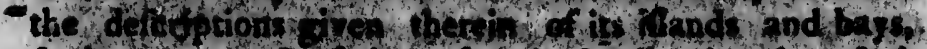

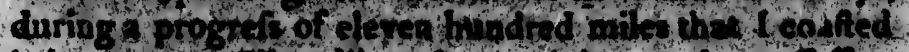

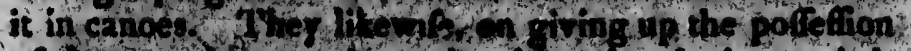

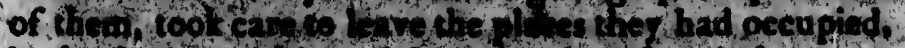

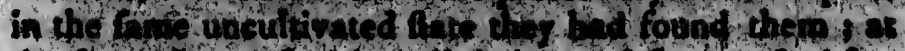

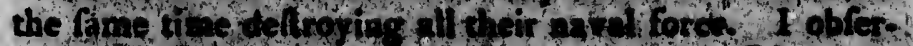

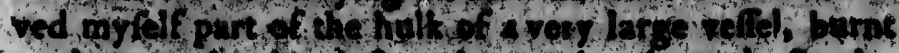

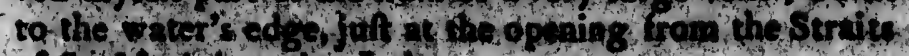
of Str Mateinto th Ink.

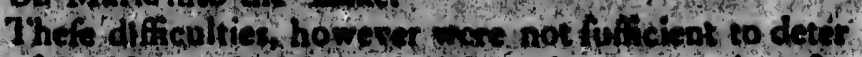
me frow the uderth thes and I made prophations for

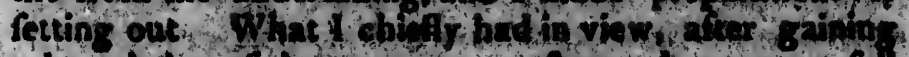

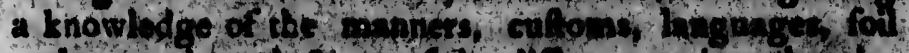

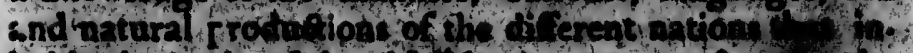

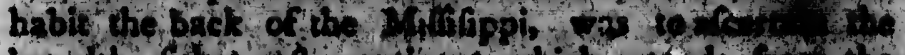

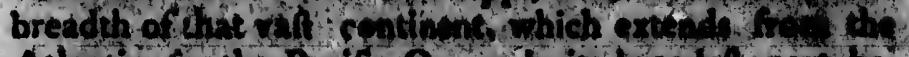

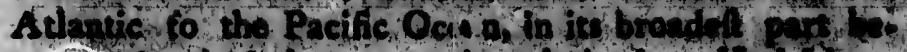

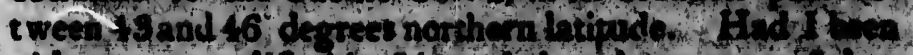
able to secomplis thin I intended to hve propold to soremment to efablib a pal in fome of the pord a

bot the covered Bitiliti cheilifio tion bots etentice fort bot: Setlopiner mans 30 Hill tonent difclarer diftertin in telligence Eaf thd ageth th elian wint

How pires ming ableconc phetion of and enten makeno protoys will robs edichas on with ceed till bat woult expetithio fuceers $\mathrm{P}$ dations an to shem 5 penct or To com culd of

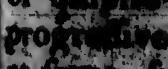
a f of (n) the anderi 
(air): four. ed 10 intsthat rins inte. that vilif ents dpar. them. thato. ling. con: esbs. ors 1. the Bants. plana: ora in 1ess. bied. efiron: ried. atas ither: anat trite.

datert fot ing

Wot die Straits of Annian, rhich, baving been frd dis. covered by sit 3rencit Drake of coth fe blong to the

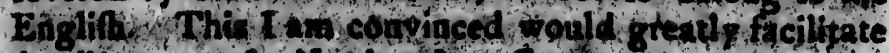
the lif co very of a Northwat patug or a communich.

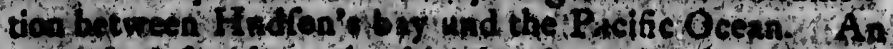

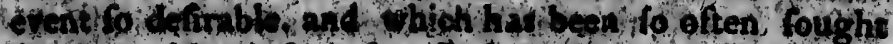

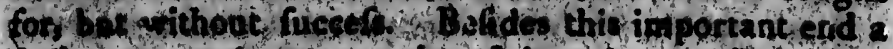

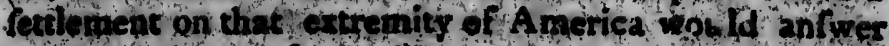

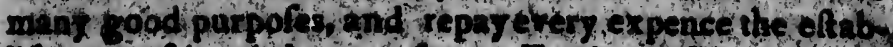

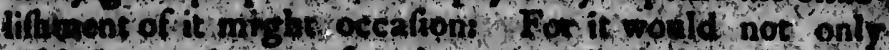

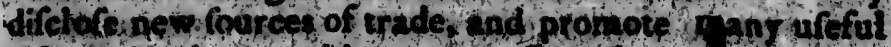
difor ties bus wopld opent paffes for to tresing in

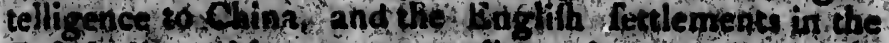
Eaf Ind w the greater expedition tha 2 bediols ro ageth the Cup of Good Wope or the straits of Mageling willation of

To far the advatages arifing frou luch on enter.

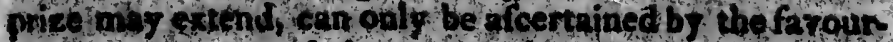
able concupend of future conth. But that the com.

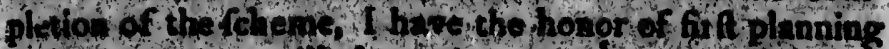

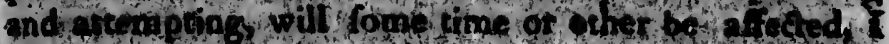

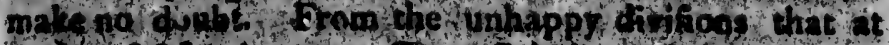

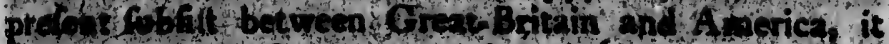
will pobably te fome jour before the attorpe in repeat

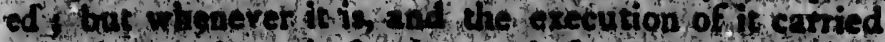
an with to riaty ghofe who are fo fortanese to to fuc-

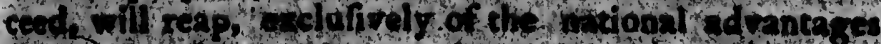

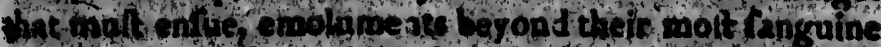

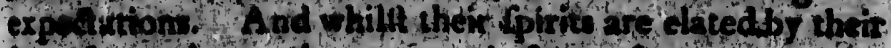
fuseds, perhaps thos mil befor forts commendatomerid blertose on the perfos who fint pointed ont

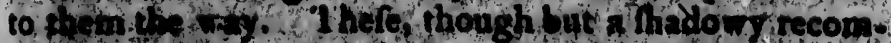

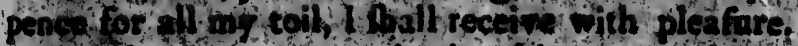

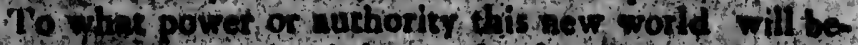

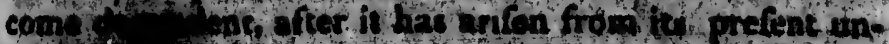

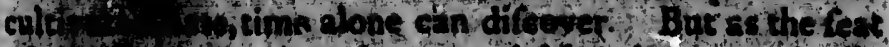

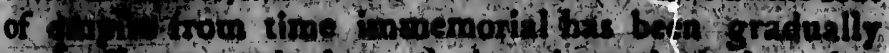

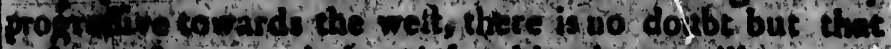

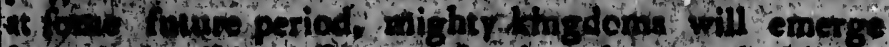

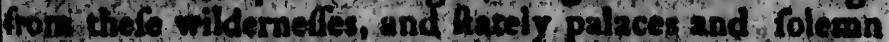

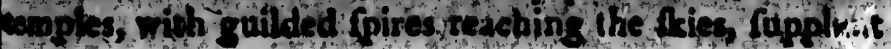

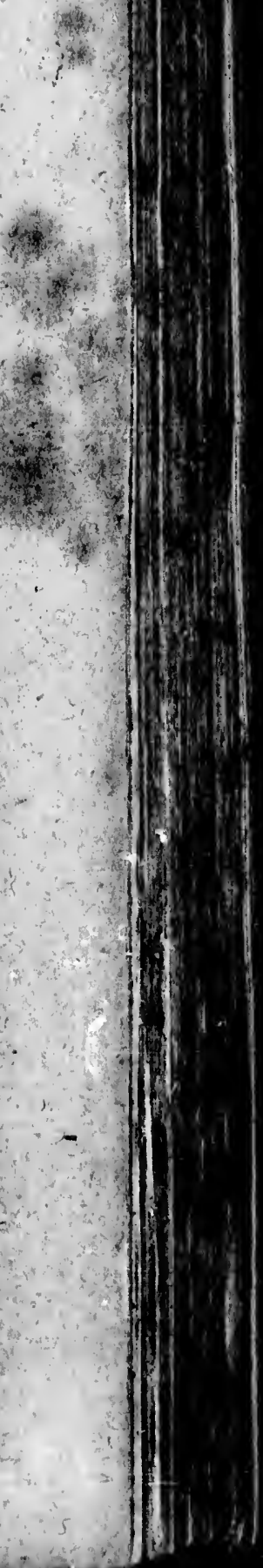




\section{so - ninlogverros.}

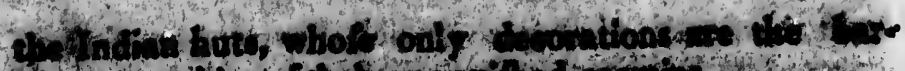

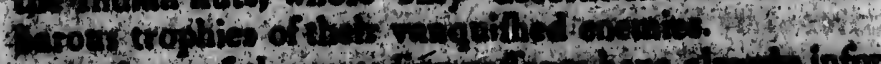

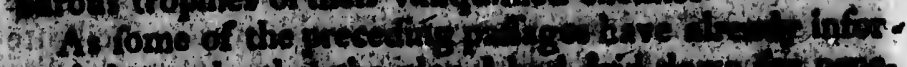

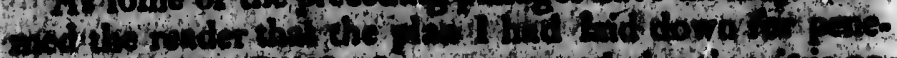

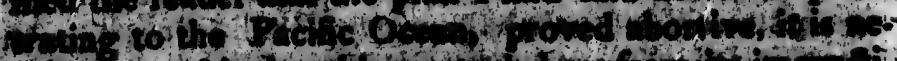

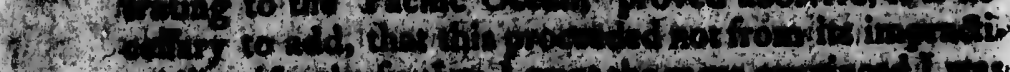

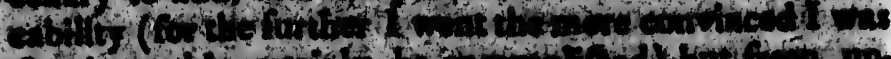

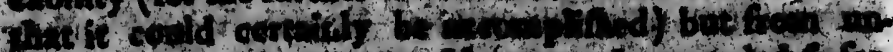

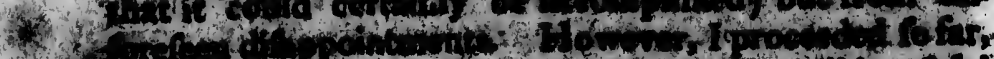

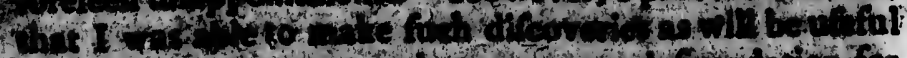

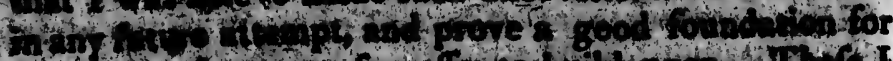

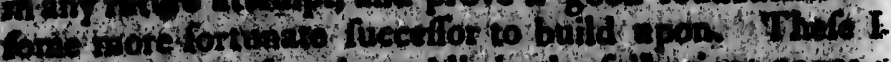

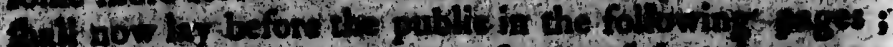

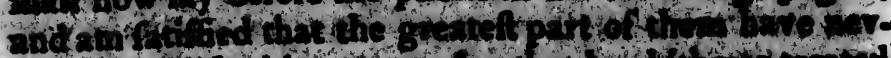

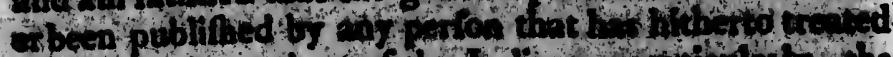

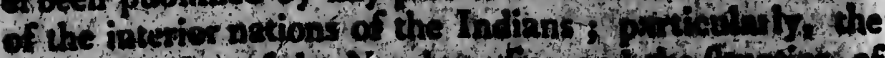

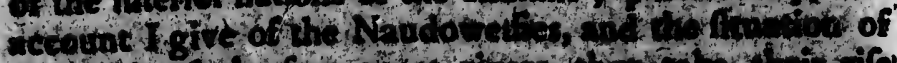

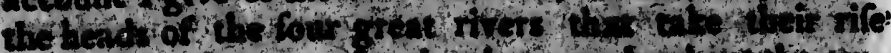

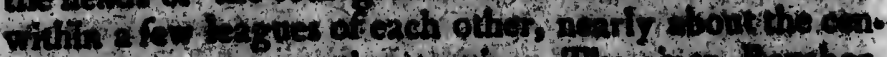

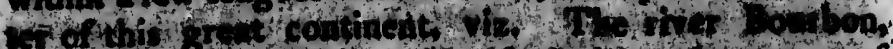

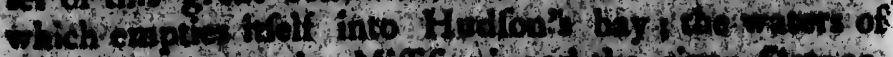

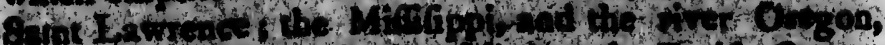

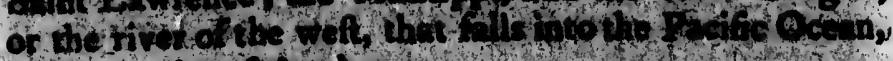

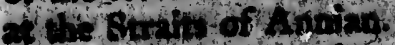

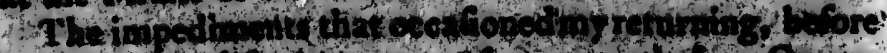

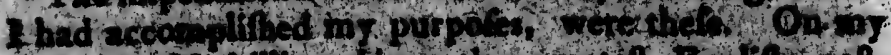

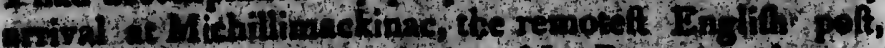

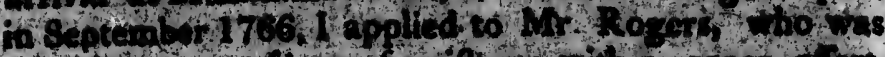
then Cownos dith to burnifi me vith a prop- itort-

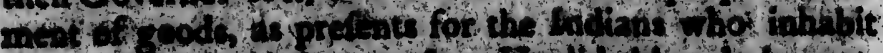

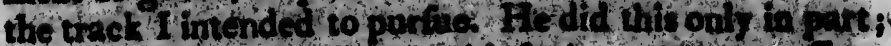

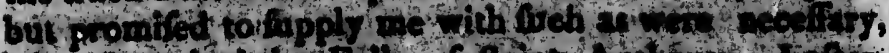

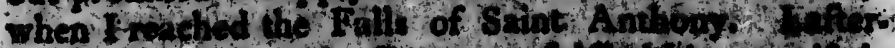

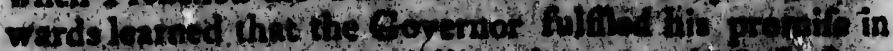

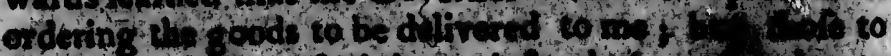

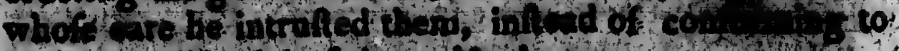
hic order difpored of them dis when

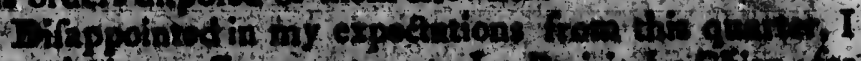

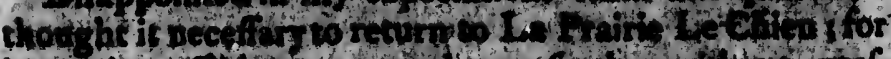

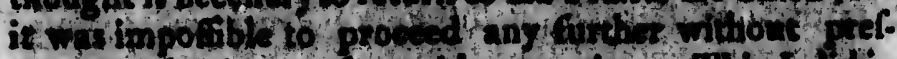

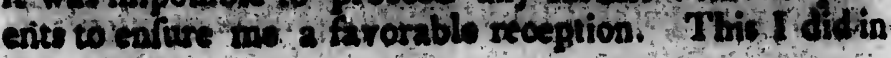

the begi tothe w cumisin $\cos 20$ itito Lal thea arially: Of chere (a) 45 du Put inciaft the sini pragers Ifecen reachis! thedist 1 6005 to. Efforost

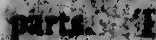
crobits Dht chatedos. plocing diat A. nterte intent Amaries, ridhate Dints? $x^{2}-4$ o. bitand thof of No itistist chon tetc crace ot

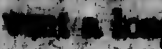




\section{mTRODECTION.}

the begining of the year 1767 ond anjling my progrefs

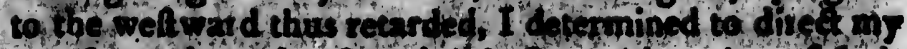
cumbs northward I took ibis Bep with a viow of findins a dem inniention from the the of the Mifinfippi

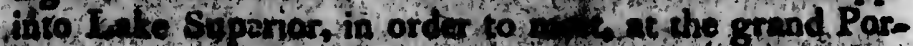

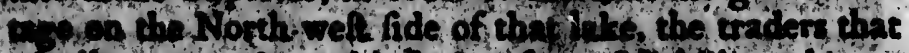

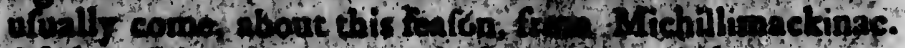

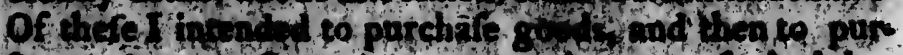

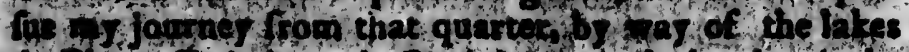
dit Fur Dobeis, and Ounipigus to the hends of the

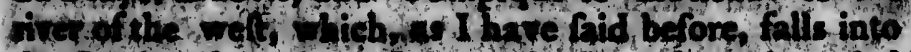
the fthiti of Annian, the stwinurion of mo intended pagento 3

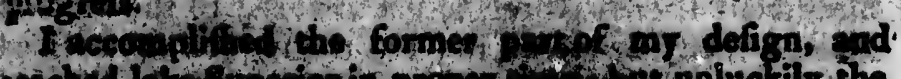

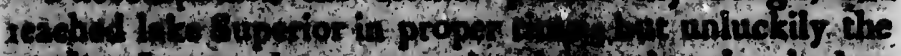

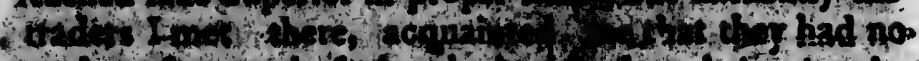

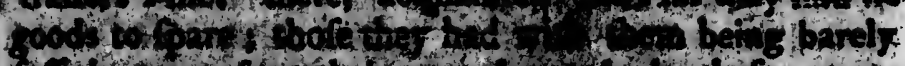

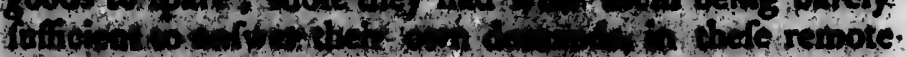

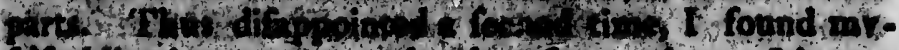

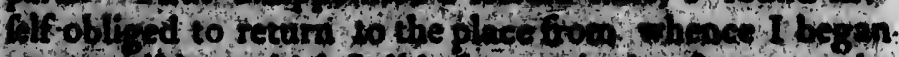

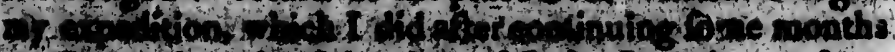

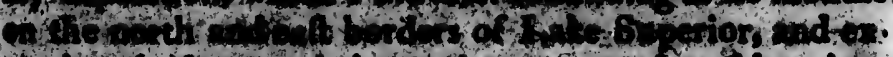

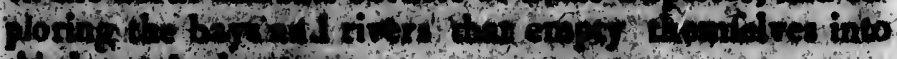

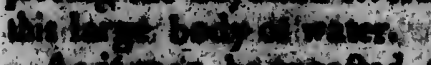

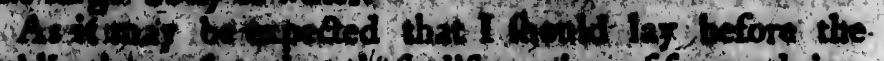

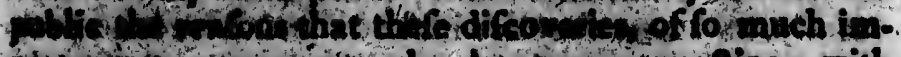

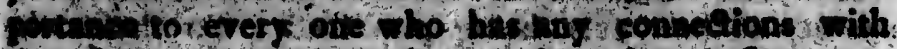

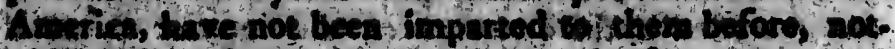

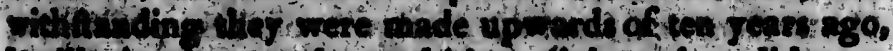

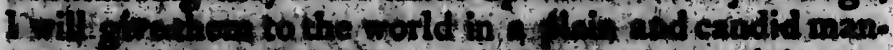

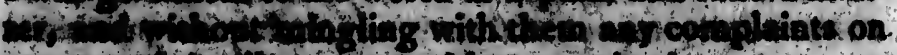

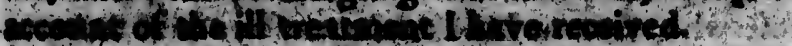

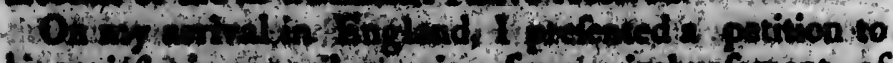

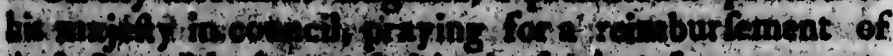

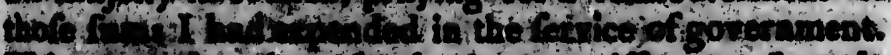

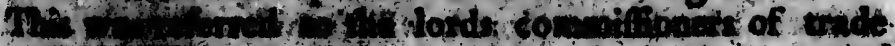

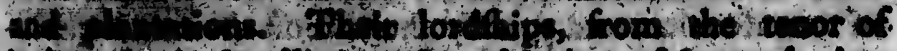

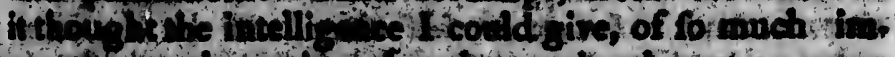

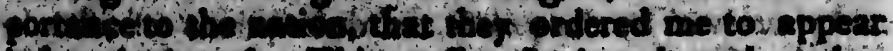

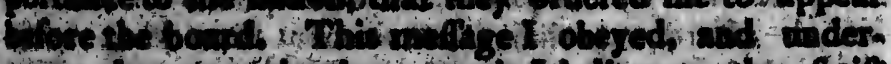

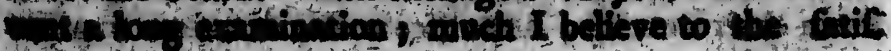


fration of every tord prefent. When it wits finithed, I tequonter to thow wat 1 hould do with wy papers; Whour hefitation dite for lord riplied that I might pub. Iith then whesioner I pletred. In conlequence of this

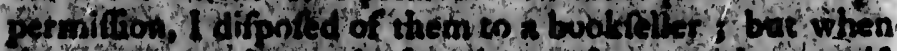

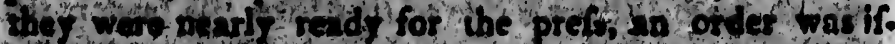
Tod froth the council board requirios to to deliver,

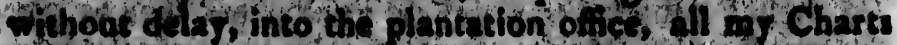

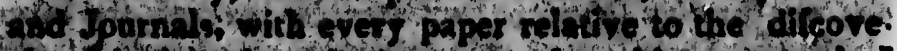

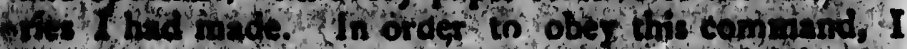
was obliged to repurchate the phot the bookfles at a very grent expen and detiver them up. This fieft dir. burfement I endes ror d to get annexed to the tecount

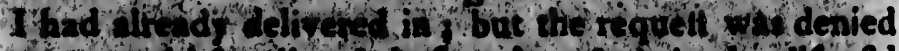

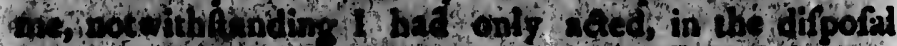

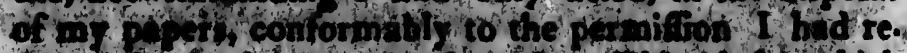

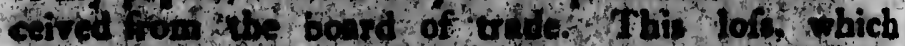

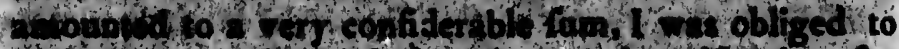

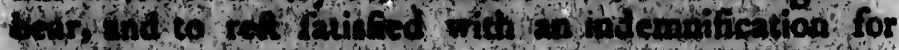
In olhet prpetas

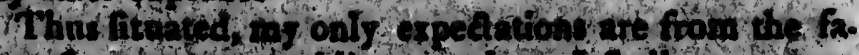

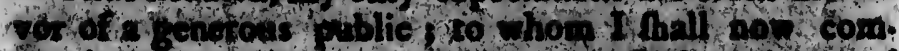

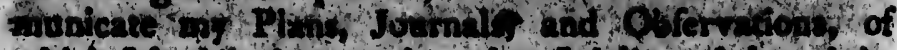
which I fuctily bopt copies, when I alivend th origin-

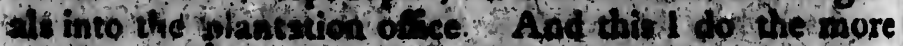

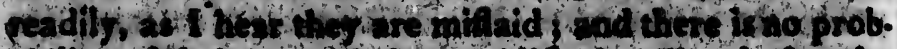
Wbility of thit over teing publiakd, To thorg whe

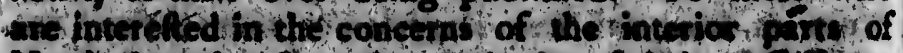

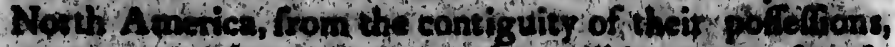

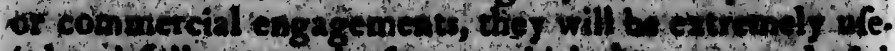

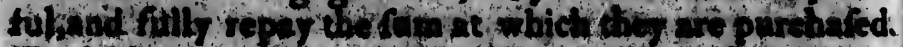

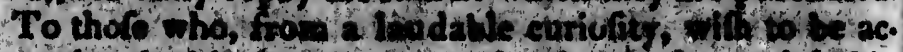

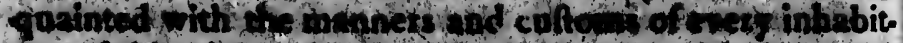

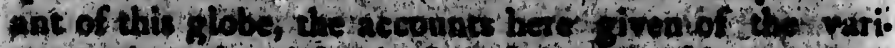

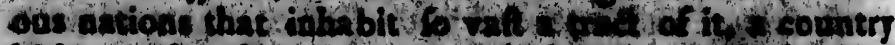

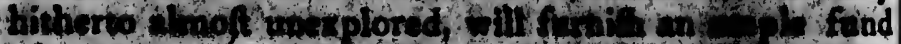

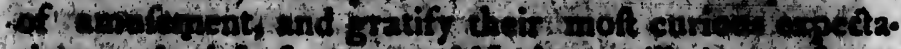

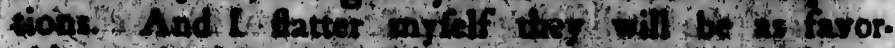
ably received ty the public as defriphtonst of intinds

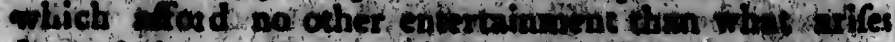

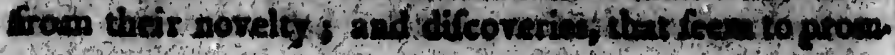

ife vant 1

ad ex in

To ms

asertain

Beconot :

dicent, ar

Ainter the duations?

(4) diting

singer of

lad $h_{1}$

karised ip

Cie prodo

Cons to 1

not nzami

Nofure

Noyed o: popiles, : Dince of 1 t to pofte oif the

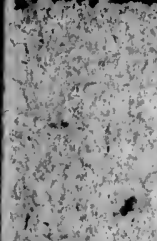


Thed, I apers; it pub. of utits twhen tras if: Wliver, Charts tifsove. and I I Destat a wili dir. decoult denied itifiofor hod te. s a bich ustod to Hon for

ang?

n com: bond of botginthe wore coproly. apsisho yint of Pefturins, binfe. wrothed. to se ac. inthabit 5 se pario teountr L ifond $t^{2}+420$ xo Etror. Brands - to arfes Hontom
Ife ren ter adrantages to this country, tuough acquit: od at un imments expence.

To make the following work 2 compreheafibe and containing as pollible, I Thall firtt give my readers ad theopiot of the rotite I purfbed over this immenfe conthont, and as I pare on, defcribe the number of inhab. Wints, the fituition of the rivere and lakes, and the pro. dudions of the country. I I ving done this I thall ureat, 4 dininet chapters, of the mannets, cuftoms and lansuctor of the Indians.

Ald here it is vereflary w befpeak the candor of the latind part of wy readers in the pervifal of it, 25 it it Wie prodinction of a perfon onnfed. from oppofite avocatops to literary purnuik. He therefore beg they fould

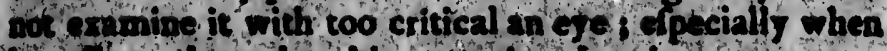
Whares them dhat his titthtion has been more $\mathrm{em}$. tofd on giving a juf defcription of a country that popiles, in lome future period to be an inexhaurtible Dirce of richer to that people who fiall be fo fortuneto to polfers it, than on the file of cotypolition, and a nerefil to render his langiage intelligibio and ez. Hoth Hifn Imoosh and florid 


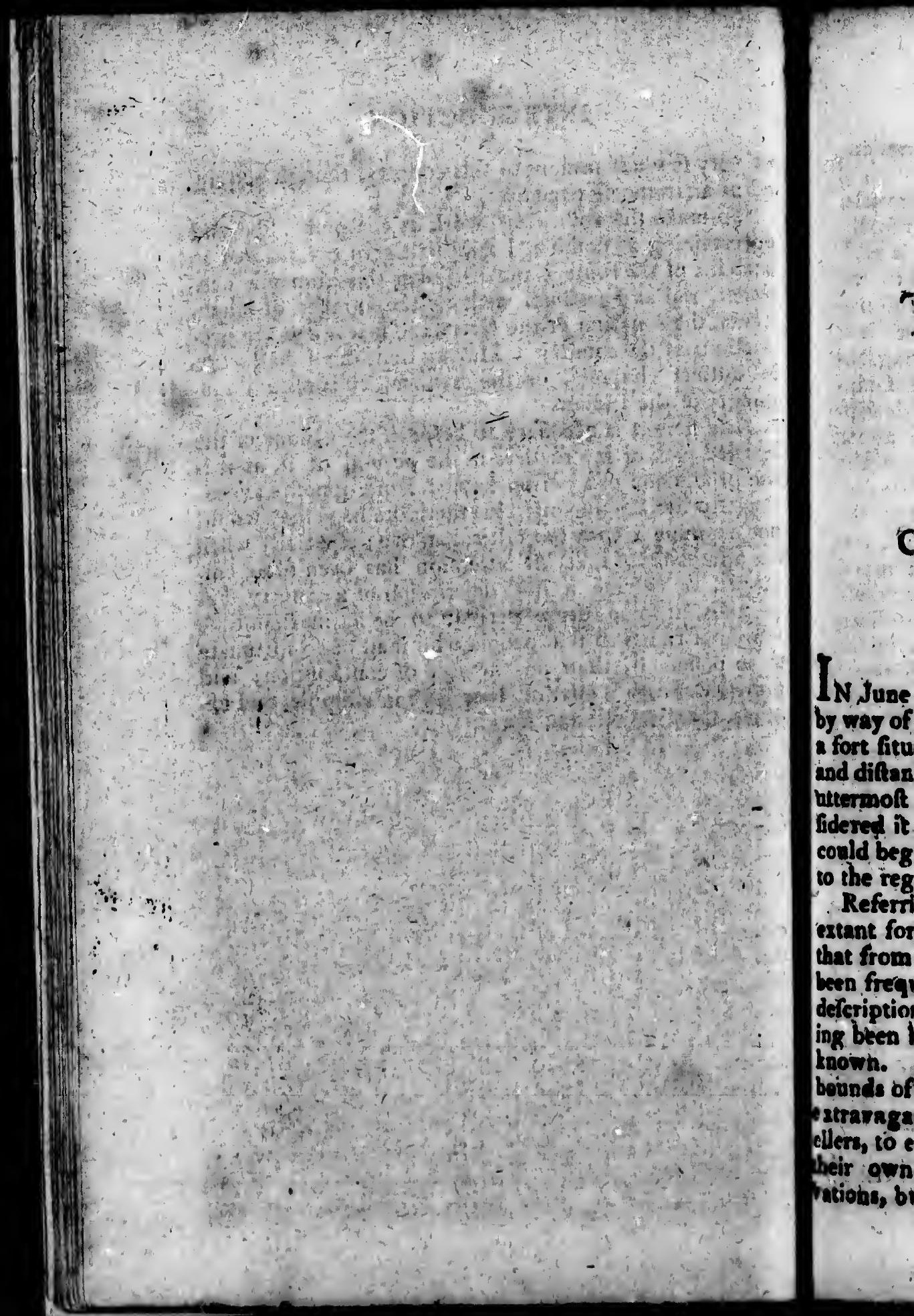




\section{$\mathbf{A}$ \\ JOURNAL \\ of TuL \\ T R A V E LS,}

พxTH

DESCRIPTION.

or TuE

\section{COUNTRY, LAKES, \&C.}

IN June 1766, I tet oot from Boflon, and proceeded by was of Albany and Niagara, io Michillimecktinac, a fort fituated between the lakes Huron and Miehigats und diftant from Bofton 1300 miles. This being the thtermoft of our fatiories towards the north welt, P cont fidered it as the moft converient place frotw whence I conld begia thy intended progreff, and enter at once into the regions 1 deligned to explore.

- Referring my readers to the publications alreads oztant for an account of thofe parts of North America, that from lying adjacent to the back fettlements, have been frequentl deleribed, I thall conline mrfelf to deteription of the more intetibr parts of it, which, hatr. ing been but feldotn vifited, are conféquently but litelie. knowh. In doing this, I thall in no inftance exceed the bounds of truth, or have recourfe to thofe ufelefs and estranagant exagerations too often made ufe of by tray ellern, to excite the curief fity of the public, or to increafe their awn importance: Nor Mall I infert any obfer. watiohs, but fuch as I l have maide my telf, or fitom the 
eredibility of thofe by whom they were related, am ex. abled to vouch for thipir authenticity.

Michillimackirac, from whence I bejan my travels, is a fort compofed of a frong ftockade, and is ufually defended by a garrifon of one hundred men. It contains about thirty houles, one of which belongs to the governor, and another to the commiffary, Several tra. ders alfo dwell within its fortifications, who find it a convenient fituation to traffic with the neighboring na. tions. Michillimackinac; in the language of the Chipeway Indian, fignifies a tortoife; and the place is fuppofed to receive its vame froth an Ifland, Jying about fix or feven miles to the north eaf, within fight of the fort, which has the appearance of that animal.

During the Indian war that followed foon after the conqueft of Canada in the year 17.63, and which was carried on by an army of confederate nations, compofed of the Hurons, Miamies, Chipeways, Ottowaws, Pontowattimies: Milfifaliges, and fome other tribes, under the direction of Pontiac, a celebrated Indian warrior, who had always been in the French interelt, it was taken by furprize in the following manner's the Indian's having fettled their plat, drew netar the pot, and began a game at ball, a paftine much ufed among them, and not unlike tentis: In the height of their game, at which forne of the tnglift officets, not frit. pecting any deceit, Alood tooking on, they Aruck the ball, as if by arcident, over the ftockade this they tet peated two or three timet, to matte the deception mote complete, till as length, having by this means Julled every fufpicion of the fentry at the fouth gate, a pas. ty rufhed by him s and the reft foop following, they took polfeltion of the fort, without meeting with ainy

- oppofition. Having accomplifhed their defighi, the $\mathbf{m}$. dians bad the humanity to fpare the lives of the grteatcft part of the garrifon' and traders, but they thade them all prifonds and carried them ofi However, fome titrie aftcr they took them to Montreal, whete they wert redecmed at a good price. Tho fort alfo wat given up again to the Englin'at the peace made wh P'oritia, by the commander of Detroit the yeat following.

Ha: fuing ers, th ers, w ceived goods the for traders with fu Indian able to ide exte to depe fipply We artived fouther ed by al. the 2 Bg on this Green ed, is fro inse in not even around exceeded and veg mer.

This being $m$ arms. their tra quilh it : furrende coned w made pr prife of garriton libe b in its bre in others 
Having here made the necelrary difpolitions for purfuing $m \mathrm{r}$ trá vels, and obtained a credit from $\mathrm{Mr}$ Rog. ers, the governor, on fome Englifh and Canadian trad. ers, who were going to trade on the Miffifippi, and received allo from him a promife of a freft fupply of goods when I reached the falls of St. Antt ony. I left the fort on the $3 \mathrm{~d}$ of September, in company with thele traders. It was agreed that they Thould furuilh to with fuch goods as I might want, for prefents to the Indian chiefs, during my continuaince with them, agrec. able to the governor's order. But when I arrived at the extent of their route, I was to find other guides, and to depend on the goods the governor had promifed to fipply me with.

We accordingty fet out togecher, and on the 18 th arrived tort $\mathrm{L}_{2}$ bay This ourt is fituated on the fouthern extremity of a bay in the Gake Michigan, termed by tl.e Frencli, the bay of Puants ; but which fince the Englith have gained polfefroh of all the fettlemenits on this part of the continent, is called by them, the Green Bay. The reafon of its being thus denominated, is from its appearance, for on leaving Michillimack. inac in the fpring feafon, though the trees there have not even put forth their buds, yet you find the country around La Bay, nutwithltanding the paffage has not exceeded fourteen days, covered with the fineft verdure, and vegetation as forward as it could be were it fum. mer.

This fort is alfo only furrounded by a flockade, and being much decayed, is fcarcely defenfible againtt tivall arms. It was built by the French for the protection of their trade, fometime before they were forced to relin. quilh it ; and whlien Canada and its dependencies were furrtindered to the Englilh, it was immediately garriConed with an officer and thirty men. Thele were made prifoners by the Menomonies foon after the fur. prife of Michillimackinac, and the fort has neither been garriloned or kept in tepair fince.

The bay is about nicety miles long, but differs much in its breadth $;$ being in fome places only fifteen miles, in others from twenty to thirty. It lies nearly from 
north eaft to fouth wef. At the entrance of it from the lake are a fring of Iflinds, extending froin poth to fouth, called the Grand Travers. Thele ars 20 o't thirty miles in length, and ferve fo facilitate the par. fage of canoes, as they thelter them from the winds, which fometimes chme, with violence acrols the bise. On the fide that lies to the fouth eafl is the nearel and beti navigation.

The Ihads of the Grand Travere are mollty fhall and rocky. Many of the rocks are of an amazins lye, and a ppear as if the had been falticined by the hilds of artifs." On the largef and beft of ther I ands tands a town of the Ottowaw, at which I found one of the molt confiderable chiefs of that nation, who reciled

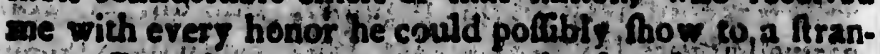
ger. But what appered extemaly lingular to to at The time, and muld do fo to every perfon unccuainted with the culforis of the Indians, we the reception I met with on landing. As our eanoes approached the thore, abd had reached within about thret foose rodf of it the Indians began a fue de.joy in which they fred cheir pieces loaded with ballis, but at the fame time they took care to difcharge them in fuch a mouner as to fy a fen yards sbove our heads : during this they stin from one tree or fiump to another, Pouting and be: having as if they were in the heat of battle. At firl I wh greatly furprifed, and was on the point of ordering ar aftendants to return their fre, conelording that theis intentions were hoftile; but being undeceired by fome of the traders, who informed me that this was their uf nal method of receiving the chiefs of other nations, I confidered it in its true light, and was pleafed with the refpect thus paid mo.

I remained here one night. Among the prefents I made the chiefs, were fome fpirituons liguore, with which they made themfelves merry, and all joined inia dance, that lafted the greatelf part of the night. In the morning when I departed, the chief attended note to the Thore, and, as foon as I had embarked, offered up; in an sudible voice, and with greac folerwnity, a fervent praj. or in ay bebalf." He prayed "thiat the Great Spirit

would would by day er blan dreams tion un he cont them.

I mi itants $c$ the fur ceived the mol convinc ple, an bors, if tuward their en of the $f$ them; ed the deep ro Ano of brea this nut they ter flice of and $\mathrm{kn}$ to dow that flo parcel i of the $t$ they ar er eat i:

This twenty found $x$

The bos 70 grewth 
it from

on north

are alsotit

the par.

he winds, the like. zarell and

ati finall zing ble, the hifids ndst tin ids one of the receithd 50. a Aranto zte at iequainted sception I rached the see rodif of they fired fane time manner as this they ng and be. At Girl I fordering that their 1 by fome is their uf. natioas, I 1 with the prefents I ore i with joined in a it. In the we to the dup, in an vent pray: seat spirit would favor me with a profpereus royage; that he would give me an unclouded $\mathrm{Ak}$, and fmuoth waters by day, and that I might lie down by night, on a beaver blanket, enjoying uninterrupted Beep, and pleafant dreams; and alfo that I might find continual protection under the great pipe of peace." In this manner he continued his petitions till I could no longer hear them.

I mult here obferve, that notwithtanding the inhab. itants of Europe are apt to entertain horrid ideas of the furocity of thefe favages, as they are termed, I received from every tribe of them in the interior parts, the moft hofpitable and courteous treatment; and am convinced, that till they are contaminated by the example, and fpirituous liquors of their more retined neigh. bors, they retain this friendly and inoffenfive conduct towards Arangers.: 'Their inveteracy and cruelty to their enemies, I acknowledge to be a great abatement of the favorable opinion I would wifh to entertain of them; but this failing is hereditary, and having received the fanction of immemoriul cufiom, has taken toa deep root in their minds to be eatily extirpated.

Among this people I eat of a very uncommon kind of bread The Indians, in general, ufe but little of this nutritious food: whitA their corn is in the milk, as they term it, that is, juß before it begins to ripen, they flice of the kernels from the cob to which thes grow. and knead them into a pafte this they are enabled to do withour the addition of any liquid, by the milk that flows from them; and when it is effected, they parcel it out into cakes, and enclofing them in leav's of the baffwood tree, place them in hot embers, wher: they are foon baked. And better tavored bread. I nev. er eat in any country.

This place is onls a fmall village containing atout twenty Give houfes and Guty or loventy warriors. I found nothing there worthy of further remark.

The land on the fouth ealt fide of the Green bay, is but very indifiereat, being orerfpread with a beavy orowth of hemlock, piac, Ipruce, and tis treee. The Chanication betwes lake Michigan and the Green c 8 
bay, has been reported by fome to be impracticable, for the palfage of any veffels larger than canoes or boats, or account of the thoals that lie between the Inands in the Grand Iraverfe: but on founding it I fcund fuflicient depth for a veffel of fixty tons, and the breadth proportionable.

The land adjoining to the tottom of this bay is very fertile, the country in general leve', and the perfpective view of it pleafing and extenfive.

A few families live in the fort, which lies on the weft fide of the Fox river, and oppolite to it, on the eaft fide of its entrance, are fome French fettlers who cultivate the land, and appear to live very comfortably.

The green bay or bay of Puants is one of thofe places to which the French, as I have mentioned in the introduotion, have given nicknames. It is termed by, the inhabitants of its coafts, the Menomonie Bay ; but why the French have denominatad it the Puant or Stinking bay, t tnow not. The reafon they themfelves give for it is, that it was not with a vie to millead ftrangers, but that by adopting this method, they could converfe with each other concerning the Indians, in their prefence without being underftood by them. For it was remarked by the perfons who firft traded among them, that When they were fpeaking to each other about them, and mertioned their proper names they inftartly grew fufpicious, and concluded that their vifitors were either fpedking ill of them, or plutting their deftruction. To remedy this they gave them fome nther name. The only bad confequences ariting from the practice then in. troduced is, that Englih und French geographers, in their plans of the interior parts of America, give differ. ent names to the fame penple, and thereby perplex thofe who have occafion to reter to them.

Lake Michigan, of which the Green Bay is a part, is divided on the north eaft from Iake Hurua by the Straits of Michillimackinac, and is fituated between forty two and forty fix degrees of latitude, and between eighty four and eithty feven degrees of weft longitude. Its greateft length is two hundred and eighty miles, its brezdch about losty, and its circumference vearly fis

hundre ands: $b_{1}$ about $t$ called i pleafan beautif On t bratich the nort Green ]

I'he v are clear navigati couniry ron, bel divides nearly n fouthern to Mich pạfies.

at the fac ions, at a

The ce of the la cept whe into it ; Near the fand cher manner They gro feet high, lie in cluf fand the bring the French, c of them but they a purpore of the Inke, danis of of the fine 
le, for boats, inds in d finfti. readth

is very pective

he weft aft fide ultivate

ofe plathe in. 1 by the sut why itinking give for ers, but rfe with prefence rémark$m$, that at them, y grew re either n. To 5. The then in. hers, in e differex thofe

a part; b) the between between ngitude. niles, its arity is

hundred. There is a remarkable ftring of fmall Inands: beginning over againt "Afkin's farm, and running about thirty miles foutu.welt into the lake. I'hele are called the Beaver Iflinds. Their fituation is very pleafant, but the foil is bare. However they afford a beautiful profpeet.

On the north weit parts of this lake the waters branch out into two bays. That which lies towards the north is the Bay of Noquets, and the other the Green Bay juft defcribed:

I'he waters of this as well as the other great lakes are clear and wholefome, and of fufthcient depth for the navigation of large thips. Half the fpace of the country that lies to the eaft, and extends to Lake $\mathrm{Hu}$ ron, belongs to the Oitawaw Indians. The line that divides their territories from the Chippeways, runs nearly notth and fouth, and reaches almoft from" the fouthern extremity of this lake; acrors, the high lands, to Michillimackinac, through the center of which it paifes. So that when thefe two tribes happen to meet at the factory, they each encamp on their own dominions, at a few yards diftance from the ftockade.

The country adjacent either to the eaft or welt fide of the lake, is compoled but of an indifferent foil, ex. cept where fmall broaks or rivers empty themfelves into it ; on the banks of thefe it is extremely' fertile. Near the borders of the lake grow a great number, of fand cherries; which ar e not lefs remarkable for their manner of growth, than for their exquilite flavor. They grow upon a fmall thrub, not more tinan four feet high, the boughs of which are fo loaded that they lie in clufters on the fand. As they grow only on the fand tbe warmth of which probably contributes to bring them to fuch perfeetion; they ar e called by the French, cherries de fable, or fand cherries. The fize of them does not exceed that of a fmall mulket ball, but they are reckoned fuperior to any other fort for the purpore of feeping in fpirits. There alfo grow around the lake, goofeberries, black currenti, and an abun. danes of juniper, bearing great quantities of berries of the finelitert. 
Sumack likewife grows here in great plenty; the leaf of which, gathered at Michaelmas, when it turns red is much efeemed by the natives. Thes mix about an equal quantity of it with their tobacco, which caufes it to imoke pleafantly. Near this lake, and in. deed about all the great lakes, is found a kind of wil. low, termed by the French bois rouge, in Englifh, red wood. Its bark when only of one year's growth, is of a fine fcarlet color, and appears very beautiful; but as it grows older; it changes into mixture of grey and red. The ftalks of this thrub grow many of them together, and rife to the height of fix or eight feet, the largeft not exceeding an inch diameter. The bark being fcraped from the Ricks, and dried and powdered, is alfo mixed by the Indians with their tobacco, and is held by them in the higheft eltimation, for their winter fmoaking. A weed that growi near the great lakes, in rocky places, they ufe in the fummer feason. It is called by the Indians Segockimac, and creeps like a vine on the ground, fornetimes extending to eight or ten feet, and bearing a leaf about the fize of a filver penny, nearly round; it is of the fubltance and color of the laurel, and is, like the tree it refembles, an evergreen. Thefe leaves, dried and powdered, they likewife mix with their tobaccos and as faid before, fmoke it only during the fummes. By thefe three fuccedaneums, the pipes of the Indians are well fup. plied through every feafon of the year; and as they are great fmokers, they are very careful in properly gathering and preparing 'tbem.

On the suth of September, I lett the Green Bay, and proceeded up For river; fill in company with the traders and fome Indians. On the 25th I arrived at the great town of the Winnebagoes, fituated un a fmall illand, juft as you enter the eaft end of the lake. Win. nebago. Here the queen who prefided over this tribe inflead of a Sachetr, received me with great civility, and entertained me in a very diflinguilhed manner, during the four dajs I cominued with her.'

The day after my arrival I held $x$ Council with the chiefs, of whom I afked permifion te pafs though 
ty; the

it turns ix about which and inof wil. lifh, red the is of ful ; but of grey of them feet, the The bark powderacco, and heir vinhe great I feason. eeps like e eight or $f$ a filver ance and refembles, ered, they id before, hefe three well fupas they properly

reen Bay, if with the arrived at un a fmall lake Win. this tribe at cirility; d manner,

with the ts though

thet country on my way to more remote nations ò bufines of importance. Ihis was readily granted me bie rovelt being elteemed by them as a great compli. meat paid to their tribe. The queer fat in the countit, but only alsed a fet queltions or gave fome trifling direaions in matters relative to the fate; for wonceth ate never allowed to fit in their councils, except they happen to be invelfed with the fupreme authority, and then it is hot cullomary for them to make any formal fpeeches as the chiets do. She was a very ancient wo. man, fmall in fature, and not much diftinguifhed bt her drels from feveral young women that attended her. Thele ber attendahts feemed gteatly pledfed whenever Illowed any tokens of refpec to their queen, particu. Irly when I fluted ber, which I frequenty did to acguire het fator. On there necafions the good old lady endearored to affume a juvenile gaiety, and by her fwiles thowed the was equally pleafed with the atten. tion I paid her.

The time I tarried here, I employed in making the beft obfervations poffible on the country and iti cols leting the molt certain intelligence I could, of the origin, language and cuftoms of this people. From thefe enquiries I have reafon to conclude, that th: Winnebagoes originally refided in fome of the provinces belonging to New Mexico; and beitug driven from their native country, either by inteltine divilions, or by the extenfrons of the Spanith conquelts; they took refuge in thefe more northern parts about a century ago.

Mr reafons for adopting this fuppofition, are, firlt; from their unalienabie attachment to the Naudoweffie Indians (who, they fay, gave them the carlielt fuccor during their emigration) notwithfanding their prefent refidence is more than fix hundred miles dif. tant from that people.

Secondly that their dialed totally differs from every ther Indian nation yet difcovered; it being a very theouth, guteral jargon, which none of their neighbor's will attempt to learn. They converfe with other na. Whis in the Chippeway tongue, which is the prevailing 
language larqughout all the tribes, from the Mohamks of Canada, to thofe who inhabit the bordsrlof the Miflifipi, and from the Horons and 1 linoik to fuch as dwell near Hudfons Bay:

Thirdly, from their infeterate hatred to the Spdniards. Some of them informed ine that thes hind many excurfions to the fouth weit, which took up feveral moons. An elder chief more particularly ecquainted me, that about forty fix wiliters $n g$ os he marched at the headic of fitty warrion, towards the fouth weft, for three mons. I'hat duxing shis expedition, whitit they

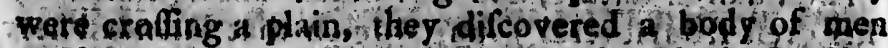
on horfe backs who belonged to the Black Psople; for fo the call the Spaniards As foop as the per. ceived them, they procesded with eaution, tis concealed themfelves till night rame on; when that drew fo near as to be able to difcern the number nad fituacion of their enemies. Finding they vere not able to cope with fo great a fuperiority by day light, they shaired till they had retined to reft o when they tuthed upon them, and, after having killed the great. ell part of the men, took eighty-horfes loaded with what thoy termed white ftove. I This I fupp ofe to have bech filver, as he told me the horfes were hod with $i$, and that their bridles were ornamented with the fame. When they had fatiated their revenges they carried of their fpoil, and being got fo far as to be out of the reach of the Spaniards that had efcaped their fury, they left the ufelers and ponderous burthen, and with which the horfes were loaded, in the woods, itnd mounting themfelies, in this manner returned to their friends. 'The party they had thus defeated, I copclude to be the caravan that annually convejs to Mexico, the filver which the Spaniards find in great quantities on the mountains lying hear the heads of the Coleredo River : and the plains where the attack was made, probably fome they were obliged to pafs over in their way to the heads of the river St. Fes or Rio del Nord, which falls into the Gulf of Mexich to the weft of the Miffifippi.

The Winnebagoes can raife about two hundred

wairiots. which ari on ritiel thists is is thie sivet, Thing bat $4 \mathrm{gen}$ at 400 W rajiat is: cantots: brekdthis batgo: Lal the land with bick The W frimton eafi cottice fortie of $t$ This I c of for havihg de from their tor.:

- The lat bounding grotit fp a great fquillies Lake itfel yearis with refort to and extrer thof that exdifinve ff to plentif Anvin: dd queen the Wintie towitos mi Fossive We juot 
Lohawiks Iof the to fuch

e Spln. ad many

feveral quainted dit the veft, for init they of men Popple; bey per. ist con. das drew ad fituannot able ht, they ien they great. ded with op ofe to ere thod ted with ges they ar as to i efcaped burthen, ie woods, turned to feated, I aveys to in great heads of he attack to pars Fes, or lexicgi to hundred watriory Theit town contains about fifty hbufes, which are ftrongly built with pallifadesgrand the ifland on wheh ft is ifuated, nearly fffy, acrés. It liès thirt for thiles, feckoning according to the coutfe of:

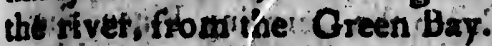

Thi iver for sbout four or fre miles from the bay; hat o gentle burrent; after that fpace, till jou arrive at to Winbebago Jake, it is full of rocks and very ratat Ar man places we were obliged to land our canotes abd curty theith a confiderable way. Its bredulth in generaly from the Green Bay to the. Winne. bafo Lake, is between feventy and a hundred yards : the land on its botders very good, and thinly wooded with hickêry, oak and hazel.

The Winnebago Lake is about fifteen miles long. frim tut to weff; and fix miles wide At its fouth eafteotfie, a river falls inco it that takes its rife near forter of the not thern branches of the Illinois River. This I called the Crocodile Kiver, in confequence. of a fory that prevails among the Indians, of their havithg deftroyed in fome part of it, an anitmal, which from their defcription mult be a crocodile or an alliga tor:

The land adjacent to the Lake is very fertile, $a$ : bounding with grapes; plums, and other fruite, which grow fpontarleully. The Winnebagoes raife on it a giteat quahity of Indian corn, beans; pumplins, fqualies and watermelions, with fome tobacco. Thi Lake itfelf abounds with fith, and in the fall of the yent, with geefe, ducks and teal. The latter, which refórt to it in great numbers are remarkably good and extremely fat, and are much better flavored than thof that are sound near the fear as they acquire their excerive frithefs by feeding on the wild rice which grows fo plemifally in thefe parts:

Ifuving made fome acceprable prefents to the good da iqueen, wid received her bleffing, I left the town of the Winnebagoes on the 29th of September, and about torivo miles from it, arrived at the place where ths Fox'River enters the Lake, on the north fide of it. Wh pocteded wp this triverjand on the 7 th of Oaber 
reached thel great Carrying Place, which divides it from the Ouikeonfin.

The For River, from the Green Bay to the cartyint places is about one hundred and eighty miles. From the Winnebago Lake to the Carrying Place the currentis gentle, and the depth confiderable, notwithAanding which, it is in fome places with difficulty that canoes can pafs through the obftruetions they meet with from the rice ftalks, which are very large and thick, and grow here in great abundance. The conn.

1 try around it is very fertile, and proper in the highell degree for cultivation; excepting in forme places near the river, where it is rather too low. It is in no part very woody, and yet-can fupply fofficient to anfwer the demands of any number of inhabitants. This river is the greateft refort for wild foml of every kind; that I met with in the whole courfe of $\mathrm{m}$ / travels i frequent. 1) the fun would be obfeured by them for fome minvites together.

About forty miles up this river, from the great town of the Winnebagoes, ftands 2 fmaller town be longing to that nation.

Deer and Bears are very numerous in thefe parts, and a great many beavers and other furs are taken ot the ftreams that empty themfelves into this tiver.

The river I am treating of, is remarkable for have ing been, about eighty years ago, the refidence of the united bands of the Ottigaumies and the Sapkies, whom the French had nicknamed, according to their wonted cuftom, Des Sacks, and Des Reynards, the Sacks and the Foxes, of whom the fellowing anecdote was trelated to me by an Indian.

About fixty years ago, the French Miflionaries and traders having received many infults from this people, a party of the French and Indians, under the command of Capt Morand marched to revenge their wrongs. The Captain fet ont from the Green Bay in the winter, when they rere unfufpicions of a vifie of :his kind, and purfuing his route oret the from to their villages, which lay about fifty miles up the Fox River, came upon thom by furprife, Uuprepared as thet

were, $h$

ly kille:

On the of the

2 confii

Atopped

his com onel of

The finds

heilloop and $h(1)$ the Chy vioble thers $p$ ed o wind of hen $f$ them in treated chiefess. femit bo and pert Abou Places! ded qui as molel the colo: my leav? miles, I The : is about the Cary orer, ex laket, th recolles except of galin in

The confin ? three 98 as 10 ap remort 
cartsmiles. ace : the otwith. lty that 7 meet ige anc - couno bighes ses near no part fwer the river is - that I requentne prin.

- great ow bo

Ce parts, atren on er. for hars ce of the Savities, to their Irds, the anecdote

1aries and is people, the comnge their en Bay in - vifie of w to their ox River, as thet were, he found them an eafy conqueft, and confequents. ly killed or took prifoners the greafel part of them. On the return of the Frinch to the Green Bay one of the Indien Chiofs in thanse with them, whr had 2 confiderable band of tu totiloners under his care, foppedito driak at a bioole in che man time his comp yone went on tw which being obforied by orie of the werten whom they had made captives.

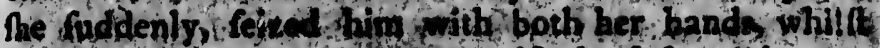
he flocped to drink by thexquifiely fufceptible part. and hnld him falt til 1 expind on the fpot $1 \mathrm{~s}$ the Chief from the extrume vorture he fuffered, was undble to collow to his friends or to give any alarm. ther pafled on without knowing what had happen. ed and the noman having cut therbands of chre of hen fellow pilfonere who vere, in the res, with then made bet eftape. This heroine was ever afteh thented by het nation as their deliveret, and made. chiefes in ber own right, with liberty 10 entail thy fomo bonor on ber defechdants lan nausual difinaion. ind perwitted only on exiraordingry occafions

About twelre miles before I reached the Carfying Plise, 1 observed fereralfinall mountains which extep. det quite to is 1 hefe inded vould only be effeened as molelills, when eompared with thore on the bock of the colonies, bur as the' were the firft I had scen thege my letving Niagares a track of near leven lyud ty mile, I could por leave them annoticed.

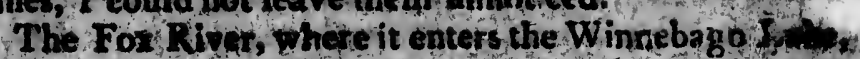
is about afty 5 ards vide, but it gredually decreafes to the Carrying Place, whete it is no more than five yards oper, except in a few places where it widens into tmall lakes, though ffill of a contiderable depth. I cannot recolled any thing elfe that is remarkable in this river, except that it is fo ferpentine for five miles, as cnly to galn in that place one quarter of $a$ mile.

The Carrying Place betreen the Fox and the Ovis confin Rivers is in breadth riot more than 2 trile und three gparters, though in forre maps it is fo delineared as to eppear 10 be ten miles. Ard here I Cand help

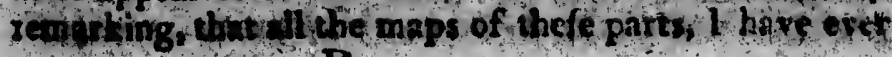


feen, are very erroneous. The rivers in general are defcribed as running in different diretions from what they really do, and many branches of them, particularly the Millfippi, omitted the difareces of places, likewife, are greatly mifreprefented. Whether this is done by the French geographers (for the Englith maps are all copied from theirs) through defign, of for want of a juft knowledge of the country, I cannot lay, $\mathrm{I}$ but I am fatinfed that travellers who depend apon them in the parts I rifited, will find themfelives much at a lors. Nearlone half of the way, between the rivers, is a morals overg rown with a kind of long graft, the reft of it plain with lome fewoak and pine trees zrowing thereon. I obferved here a great number of ratujefanke. Monf. Pinnifance, a French trader, told me a remaikable ftory concerning one of thefe reptiles, of thich be fald be was eye witnets. An Indian belong. (ing 10 "the Monomonie nation, having taken one of them, found means to tame it s and when he had done this, treated it as a Deit's ; calling it his Creat Father, and carrying it with him in a box, wherever ho vent. This the Indian had done for feveral fummers, when Monf. Pinnifance accidentally met with him at thit Carrying Place, juft as he was fetting of for a winters hunt. The French genteman was furprifed, one diy, to fee the Indian place the box which containod his God, on the gtound, and opening the door, gere - This liberty, telling him whill he did it, to be fure. tud zeturn by the sime he himfelf thould be back, which was to be in the month of May following. As this was but in Osiobet Monfieur cold the Indian, whofe fimplicity aftunithed him, that be fancied he might vait long enough when May urrived for the as. rivil of his great fatber. Ihe Indian was fo confident of his creature's obedicnce, that ho ofrered to lay the Frenchman a wnger of two gallons of rum, that at the lime appointed le would comie and crawl into the box. - This Wus agreed on, and the fecond reek in May fol. low ing, fiscd for the duter mination of the wager. "At shat puriod they both nist thete agains uhen the Inp dian dit divo his box, ard called for his great facher. 
are defhat they icularly places, this is fith maps Cor want ay, but them in t 2 lots. rers; is a the reft growing ff ratuie. told me ptiles, of 4 belong1 one of had done E Father, bo vear. rs, when at thit - a wina ifed, ons sontained or, gavé o be fore be back, ing. As Indian, ncied the or the as. confideut lay the uat at the the box. May fol. ger- As! the lnp it forbert.
The Inake heard him not; and the time being now expired, he acknowledged that he bad lolt. However, withvit feeming to be difcotarged, he offerc d to double the bet, if his great father came not within two dajs mure. This was further agreed on then be. hold on the second day about one o clock, the fnake atrived, and of his own accord crawled into the binx, which was placed reaty for him. The French Gentle. man viuched for the truth of this fory, and from the accounts I have often received of the docility of those ereatüres, I fee no reafon to doubt his veracity.

I obferved that the main hody of the Fos river cane from the fouth than that of the Ouilconfin from the north ealf $;$ and alfo that forme of the fmall branches of thefe two rivers, in defcending into them, doubled wits. in a fow feet of each other, a little to the fouth of the Carrying Place. That two fuch rivers flould talie their rif to near each other, and after running fuch dife ferent courles, empty thechfelves into the fea at a dis. tance fo amazing (for the former having paffed through feveral great lakot, and rin upwards of two thoufand miles, falls into the Gult of St. Lawrence, and the othex, after joining the Miflitippi, and having run an equal number of miles, difembogues itfelf into the Guif of Mexico) is an inftance (carcely to be met in the exten. fre continent of North Imerica. I had an opportu. nity the fear following, of making the famo obferviltions on the aftinity of feveral head branches of the waters of the St: Lawrence and the Mifflippi to each other and now bring them as a proof, that the opin. ios of thofe geographers, who affert, that rivers taking their rife fo near each othet. unult fpring from the fame fource, is erroneous. For I preceived a vifibly diftina feparation is all of them, notwithlunding, in fome places, thoy approached fo near, chat I could have Repped from one io the other.

On the sth of Oetober vie got our canoes into the Ouifconfin River, which at this place is more than 2 bundred yus ds wides and the next day arrived at the great town of the Saukies. This is the largelt and helt buili Indien town I ever faw. It containsahout aincty 
houfes ench large enough for feveral families. These are built of hewn plank, ticutly jointed and covered with bark fo compedely as to keep out the trolt pene. trating rains. Before the doors dte placed comfortable Aledi, in which the inhabitants fit when the weather will permit; and fmoke their pipes. The treets are regular and fpacious if fo that it appeart more like a civitized tovin, than the abode of favagea. l'he land near the town is verry good. In theit planthtionis, which iif adjacent to their houfes, and which, are neats, lid out, the s taife great quantities of ladiah corn, bens,

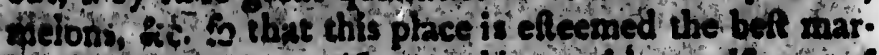

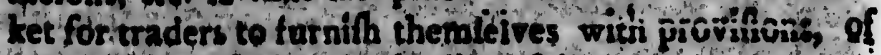
shy within eight humdred miles of it.

19 The' Sauktes can rail about threchundred warriors, Who ure generally employed every futhmer in making Theurfions ineo the cerritories of the lllinals and Pav. Dee nations, from whence thef return, with a groat number of Aaves But thot people frequenth ratad. fitd wndr in their turn, deftroy many of the saupies, Thich t jodge to be the reded that they increate no Ealter.

Whild I laid here I conk a view of fome mountains that lis about fitcen miles to the fouthward, and abound in lead ore. I afcended on one of the highelt of thert, hid htd an extenfive view of the country. For many miles nothing was to be fen but toler mobntains, Which appeared at a dillance like hajcocks, they being fre from ties. Onlt a fow groves of hickory, and livinted onks corensd lome of the vallies so plenti. fulfs lead here, that I faw large quantitios of it, Iying doout the direts in the town balonging to the Saukies. and it levmed to ko as good as the prodvice of other couptries.

On the loth of Oelobet we proceded dowt the riv. $a_{1}$ and the next day reached the fril toim of the Otti.

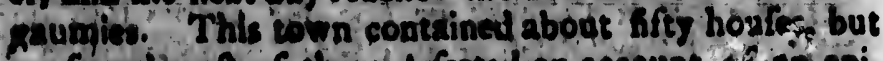

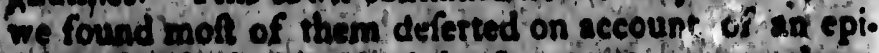

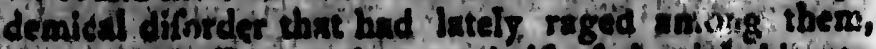

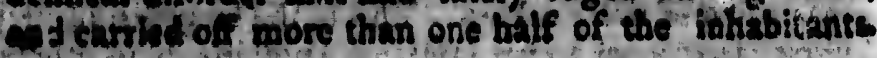

The 8 into th

On 1 hifppi. the par Imooth ingly $c$ fandy $t$ iflands, (omew) ed to b very fo lead $m$ Abo ferved ation.

it than yeane a - prta cowand tions : to biris who 8 ith be atels of addref The It mirnou we the mays afom vow I hoo Thi an the ifrown? Chien and co an Chunb rg naver 
These covered bit pene. sfortable weather iects are 'like a I'he land is which atis Jiid b. beens, teit thar. fficitio of tarriors, making ad Par.

is gritat tht retal. Srulfits, teafe no

ountains dabound of therte, or many obntains, ey being ory nand 30. plenti. it, Jying Saukier, of other

$n$ the rit. the Otriinto bue ax epiig there, abitantes

The greater part of thofe who furvived, had retired into the woods to aroid the contagion.

On the 15 th we entered that extenifive river the Mis. fifppi. The Ouifconfin, from the Carrying Place to the part where it falls into the Miffifipi, flows with a Imooth, but ftrong current; the water of it t exceedingly clear, and through it jou muy percieve a fine and fandy bottom tolerably free from rocks. In it are a few iflands, the foil of which appeared to be good, though forewhat woody. The land near the river alfo feem. ad to be, in general, excellent \& but that at a diftance is very full of mourtains, where it is flid there are many lead mines.

About five miles, from the junaion of the rivers, 1 ob ferved the ruins of a large to wh, in a very pleafing fituation On enquiring of the neighboring Indians, why it was thes deferted, I ons informod, that about thirty reare age, the Great Spirit had a ppeared on the tog of - pytamidiof rocks, which lay at a litte dilance from its cowardo the wel, and watned them to quis their habits. tions if for the laad on which they were built belonged to hisu, and be bad occalion for it As a proof that he, who gave them thele orders, was really the Great Spirit he further told them, that the graft thould immediatels fpring up on wote rery rock from whence be naw addrefied thine. which tho knew to be bare and berrea. The Indians obeyed and $100 \mathrm{n}$ after diffovered that this mirreculocis alserntion had taten plape. 1 hes thewed we the fpot but the gromth of the grafe appeared nnimays fupertutural. I uppreticad this to tiave been a fir,t-

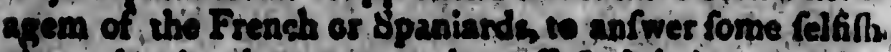
Yow I but in what mannar they effotad their purpofes. 1 thos not.

This people, foon after their remord, built - cown. ca the bant of the Mitelspis near the month of the Ou.

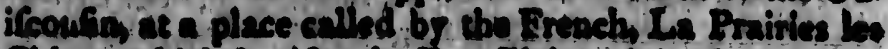

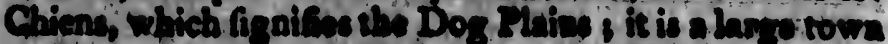
and contuins about thros budered fanilions the boufer.

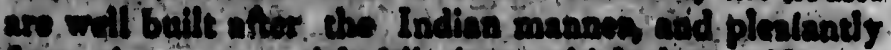

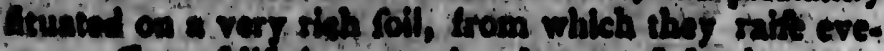

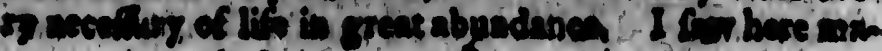
. 2 
ay horles of a good fize and thape. This town is the great mart where all tice adjacent tribes and even thofe

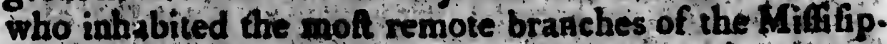
pi, annually affermble about the latter end of May, bring. ing with them their furn to difpofe of to the traders. But it is not alway that the conclude the fale here, this is determined by general council of the chiefs, who contht whether it urould te bore conducive to their intereff tó fell theirgoods at this place or carry them on to Louiliana, or Michilimackinac. According to the decifion of this council, they either proced furtlier, or return to theit different bortes.

The Miflifppi, at the eatrance of the Duifcantin, neat which fands 2 mountain of conflderable hoight, is about half a mile over, but oppofite to the taf mentioned town it appears to be more thas a mile wise, and fulf of Iflands, the foll of which is extraterdinary rich, and but thithly wooded.

A little furtbert to the welt, on the conta ury fide; a mall rive falls into the Miffifippi, which the Trench call Ite Jauh Riviere, or the Yellow River. here the tradere who had accompanied me hitherto, took up their ivefs dence for the winter, I tien bought a cance, and with two lerrante, one a French Canudian, and the otties a Mohawk of Canada, os the loih proceded op the the Gfippi.

A bout ten days fuet 1 had panted from the tredend $\mathrm{I}$ landed as I vraally didietery everning, and haviag piuched in tent, I orderted my mea, whed nighe come on, to Jay themiletice down to Deep. By a lighe quat I keppi

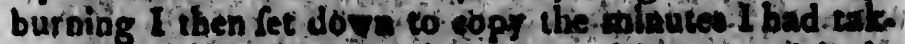

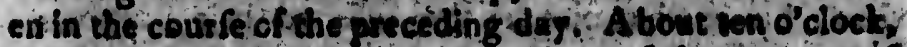
baving juff flnithed iny memprandoms, I fiep ped one of

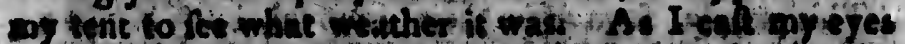

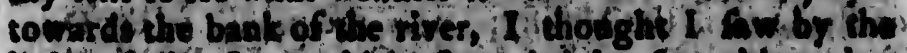

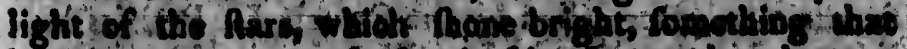

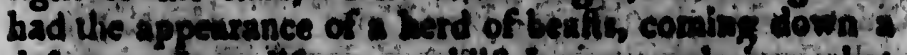
defcew at to

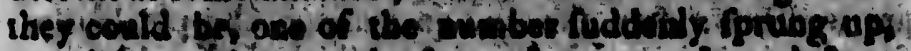

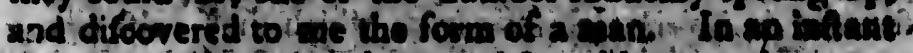

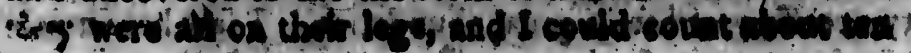

or tweln reehterer deried atis firlt aph ter's fide difconte Beforct 1 till Ihad tilities on ly advan fpears, th hanger, 9 ed lnthe vere lits and preci adjacenit of themin ed alcorm sert das. and carne hid ingly be eftem ameogict terminod when ons this they to griard Indiand w wards fou witigy be thicti the thenelive conbliven

an Indtits

indibefor

berifintich thole buf

Odith Mtele is of aboshy: nding 
a is the. an thofe. riefifipibring: s. Bue this is confetit etefts to uitiana, of this to theit

Sth near te, is arention. le, and. ich, and

is frall call Ite tradore sir viva ad with ottivet a be the int raden: I: sivel. on, to It telept ad :at

ocelock $10 \mathrm{cos}$ of

mpieses aby the atisen dowa notint iogopis ing the

or twelve of them rumning towards me. I impediately reebtered the teot, and haviog awakened my men, ordered atiem to take their atms and follow me. As my. firft apprehesflons were for my canoe, I ran to the was ter's fide, and found a party of Indians (for fuch I now difconeted them to be) on the point of plundering it. Before I reached thern; I commanded my men hot to fire till Illad given the word being unwilling to begin hof: tilities unless oteafion absolutely required I according: ly advanced with refolution, clofe to the poitse of aheir fpears, they bat so other wexpons, and brandifting tiny hanger, afked them with artern voice, what hey want: ed t They were taggered av thit, and perceiving they were like to mét with a frare reception, turned a bout and precipiately retreated $\mathrm{We}$ purthed them to at adjacent wood which they entered, and we faw no move. of themal Howevery for fear of theis retus as we watchit ed altionately during tbig retnainder of thenght $T$ the

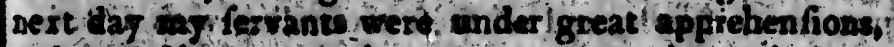
and earnelly entubied pe ta return to the traders iwe had levelgiteft Boc I told them, that if thej would not

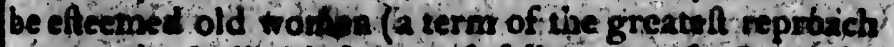

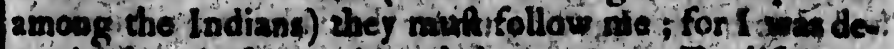

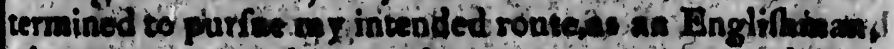
When once engaged in wa adveature te er nétreared. On. this the y got into the eaves god I walkedion the there

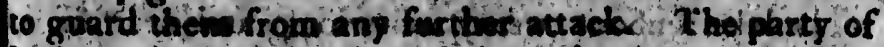
Indiens whor had thus intended to plunder me, I vifien wards found to be fogne on tho ff ftragglints bands that hivitig been dsiven from dinong the differeme tribes to.

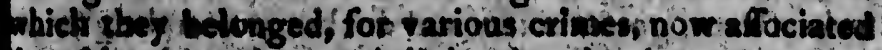

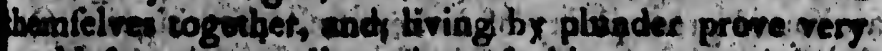

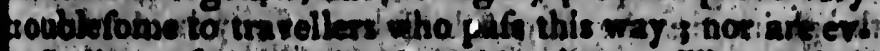

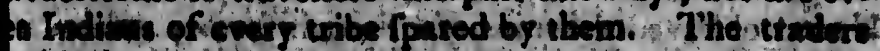

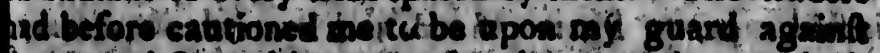

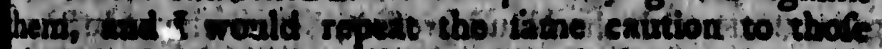

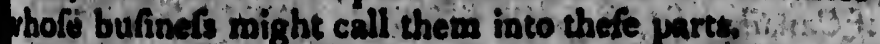

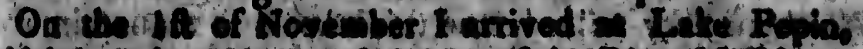

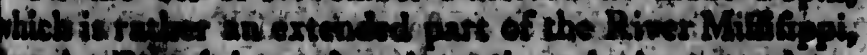

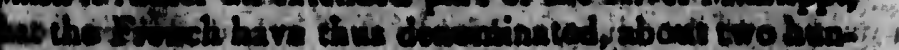

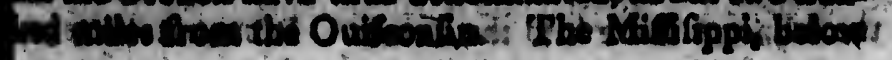

\section{(1)}


this lake, lows with a gentle current, but the breadth of it is ver uncertain, in fome places it being upirards of a mile, in others not more than 2 quarter. This river has a range of mountains on each fide throaghout the whole of the way ; which in particular parts approach near to it, in others lie at a greater diftance. The land betwist the mountains, and on their fides, is generally covered with grafs, with a fer groves of trees interfperf. ed, near which large droves of deer and elt are frequentIj feen feeding:

In many places pyramids of rocks ap peared, refeanb. ling old ruibous towers; ut others amasing precipices; and what is very remarkable, whill this fcene prefented itferf on one fide, the oppofite fude of the fame mountain was covered with the frefel lerbage, which gradually afconded to its fommit. From thence the mof beatiful and extenfive profpeet that imagination can form, opens to rout view. Verdant plains, fruleful meadows, numerous iflands, and all thefe abounding with a rarie. tr of tres that yield amaning quantities of fruit without care of cultivation fuch as the nut tree the maple. which produces fugar, wines load d with rich grapes. and plomb trees bending under their blooming burdens, but thova all, the fine friter fowing sendly beneath, and rechitas as for os the ore can entend, by turne atuad. your ad wiration and excite jon tonden

The like is about tweaty. villestong and near. fx in breadth $g$ in fome placss it is rery deep, and abounds with various kinds of $6 \mathrm{fH}$. Creat turibers of forl frequent alfo this lake and the riversiadjacent $y$ fach at forks, fwane, geefs, brans and ducks 8 and in the groves are found great pleaty of turliey and partwid ges. On the phins are che largell buifalos of ary in America. Hetl 1 obferred the ruins of a Fench fuctory, where it is fid capt st Pierre refided and carried on 2 rery Hen ton with the Nandoweffen before the reduction ef Cunad

Alon faty milo telow this lake is a monstein re

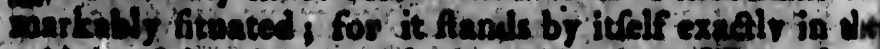

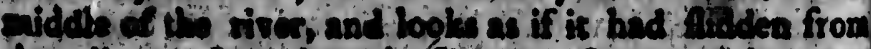

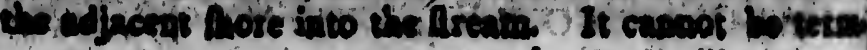

ed an the wa and the

One fome m ptepari the adj fore I c ceired o appeara I had 8 intender it wasin that it is beigtht, If capac fornewh Though gallinb as much The dib more cu been one it mult: the coun was liser comrnar teen nea crols it: depth 0 I way $a$ ? quit): great at not exet? of it. of a bea takes tre Mons 8 tintersite havie ifo Salder eto 
readth of ivards of his river hout the approach The land generally iterfperf. frequent-

, refemb. ecipices: prefented. motntain zradually if beautican form, meadors, h a varieit without he maple: h grapes. burdens, neath, and ins autrad.

near $6 x$ in d'abounds if forlifreit y fach as. the groves. dget. On America. 7. where it on 8 rety reduction

shatr in die des from of twiterta ad an if and, as it rifes immediately from the brink of the water to a confiderable height. Both the Indians and the Freach call it the Mouncain in the Rirer.

One day having landed on the fho re of the Mifrfippi, fome miles below Lake Pepin, whilt my attendants were pteparing my dinner. I walked out to take a nie of of the adjacent country. I had not proceeded far bsfore I came ta a fine, level, open plain, on which I perceived at a little diftance a pertial elevation that had the appearace of an intrenchment. On a nearct in peation I had greater reafon to fuppofe that it had reall been intended for this many centuries ggo Notwithfonding it was nowicovered with grafs, I could plainls difceng

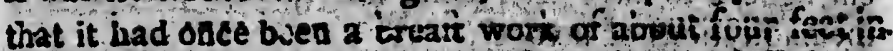
beigtit, extending the befl part of a mith and furfigicht-

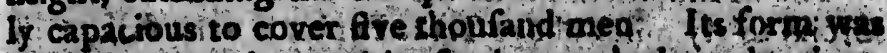
tomewhat circular, and its flanks reashed to do sivats Though thich defaced by time, etery angle was, difin gaithible, andiapposred us regalar, and fahioned vith as muck milicary flatls as if plenned by Vauban himfels: The ditch was not vifible, but I thought on exaphinth more curioufly, that $I$ could perceive there certainhly hot been one. From its fituation alfo, f am coarinced the it mult have been defigned for this, purpofor I I frouted the country, and the reac was cavered by the rives 3 , nor was tiere any rifing ground for a conliderable way, that commanded it ; 12 few Araggling oals were alone to be feen near ic In many places imall irages were wom acrofs it: by the leet of the elks and deer, and from the depth of the bed of earti by which it was covered. I wio able $w$ draw centain conclnfions of its great antiquit). I examined all the angles, and every part with great attention, and have oftea blamed my felf fince, for not eneamping ot the fputi and draving an exa 4 plan of it. To the that this defeription is not the of pring of a beated imarination, or the chimerisal tale of a maif. takes travillen I find on enquiry fence my retura, that Mons St Pierre, and fefreral traders, have, at differeyt titice, tratien wotice of fimilar appearaneses on which thet havel formed the fame conjectures bue miphout exp's. Wath them fo minutily as I did. How a wetk like this 
kind couldexilt in a country that has hithorto (zecording to the general tecsived opinion) been the feat of war to untutored Indians alone, whofe whole fock of military tnowlestge has only, till within two centaries, amount. ad to drawing the bow, and whule only breafwork, crea at prefent, is the thicket I know not I have given as exat an accotnt as folible, of this fing uler appearance; and leave to future explorers of thefe diltant regions, to difcover whether it is a production of nature or art.

Perhaps the hints I have hore given, might lead to a more prrfet invelfgation of it, and give us very aifor. chit idens of the ancient ftate of realms that we at pref ont beligve to have been from the earlief period only the habitations of favegea

The Mifipppi, ws far as the entrance of the River St. Croix, thirt mile above lake Pepin is ver full of in ands, come of which one of a confiderable length. On thecelis, grow great numbers of the maple or fugar tues and around them rines loaded with grapes criep. ing 6 their rery tops. From the Lale upwaids, few mountains an to 60 feen and thote but finall: Neat the diver Sa Crois, rafide three bands of the Navidowat. Se Indians, elled tho River Bands.

This nation is cowpofod, at prefent of eleven bands. Tey were osjguals twelve, but the Afinipoils fome yetre ago, revolting, and coparatiag themfeloes from the othese there remein onh at this time eleven. Thofe I met hene are vermod the kiver Baods ; becaufe thes chielly dwell near the bxhts of this river: the oth. et eight are genenally diltinguithed by the title, Na udo repres of the Plains, and inhabit a country that lies more to the weft ward. The names of the former ate the Ne. hogatejoinahs, the Mawtawbauntowahs, and the Shulis. weertorwahicand confift of about four hundred wartions.

A titule before I met with thefe three bands. I fell in With a party of the Maw taw batntowahe amounting to forty uarriors, and their families. With thefe 1 refided a das or two, dúring which time five or fis of their Wuibar who had boep ont onan excurfion, returned in Sreat batt and acquainted thuit companions that a firge party of Chippewas warriorts "epough" ag they

exprefie dole at littie cas rould: $\mathrm{p}$ oppofe liag to how to: ne. $H$ Láve dra Chipewa that: nol io have twre occe verity of middle a ciffer me thir fur raded botween $t$ Thling thoir lang Chiporre during th ed them chiefs co If merone interprete which va form nee ont acsor difcourfe thet thy armed wi Hain cod thing pould in (4. tovis difor had They ac 1) pespot Hothis, 
ccording $f$ war to military amóunt. prk, even given as earance; gions, to art.

ead to a t) aifior. e at prefiod only

River St. ill of if: gth. On or fygar pest crivep. ards, fev lail: Near Jaudowef.

en bands. Afinipoils herifelves oe eleven. - becaufe : the oth. e, Nauda t lies more ire the Ne. the Shulis. 1 wartions. is I fell in ounting to E. Irefided $z$ of their cturned is ons that a h." an thes
Coptefed themielves, "to fwallow them all up" wers dofe at their beels, and on the point of at tacking their litte camp. The chiefs applied to me and defired I hould put myfelf at their head, and ad them out to oppole their enemies. As I was a utianger, and unvil. liag to éxcite the anger of either nation, I keew not bow to act; and never found my felf in a greater dilem. 12. Had I refufed to affit she Naudoweffes I Alould have drawnon mirfelf their difpleafure, or had 1 met the Chipeways with hootile intentions, I hould have made that pople my foes, and had I been fortunate enough to have efcaped their arrows at this cime, on, fome fil. ture occafion Dhould probably have experienced the fe verity of their revenge. In this extremity I chole the middle courfe, and defired that the Naudnweffies would fiffer me to meet them, that 1 might endeavor to avert their fory. To this they reluatantly affented; being per. fraded from the inveteracy which had long prevailed botween them, that my remonftrances would be in rain. Tuing mi Frenchman with me, who could fpeal their language, I halfened towards the place where the Chipewajs were fuppoled to be. The Naudorieffes, during this, kept at a diftance behind. As I approach cod them rith the pipe of peace, a fmall party of their chiefs confifting of about eight or ilen, came in s friendIf menner towards me, with whow, by the uneans of my inverpreter, I leld a long converfition the refule of which was, that their sancor being by my porfuafions in fom meafure mollified they agreed to turn back, with. ont accomplithing their favage purpores. Daring ons difcourfe 1 could percéive, af the las feattered about, Chat the party was very numetous, and many of thom arued with mulkets.

Having hapily fucceeded in my undertaling. I return. ed thikout delay to the Naudopeflies, and defired thes yould infant r remote their camp to fome otper part of

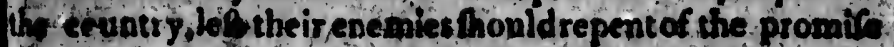
Wh had givent, and put their intentions into execption. They accordingly followed my advice, and ingmediate. 1) piepared to lrite that tente whila they we doA this, theg loadad me with thanks, and when I but 


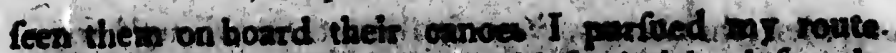

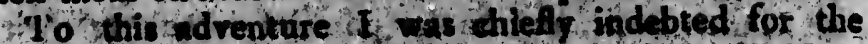
friendl the teption I afterwards met with from the Nau. doweffes of he pleins, ahd for therefpes and honors I received during my abode aroing them.

Arid when Itwed math month ifter at the Chip. pewey village near the ofongtr lates I found that wh fame had teadred thas lolace it fore ane. The chiefs received mo wh igreat cordiality and the el. derpart of them athled the for the drifchief ihad

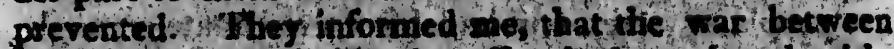

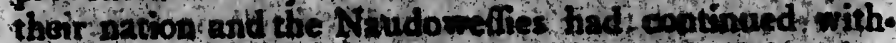

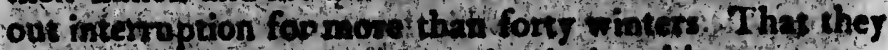
thed low withed ro pot an end to it bet this was gecer.

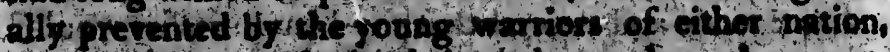

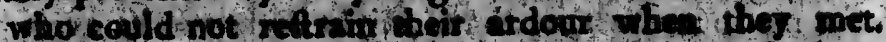

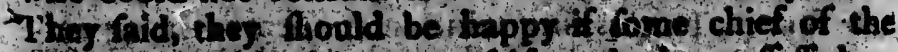

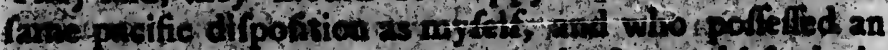

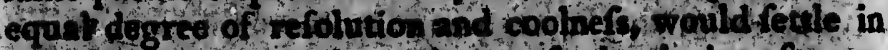

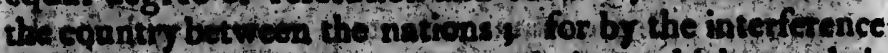
oftuche potha, w accimmodation which on their

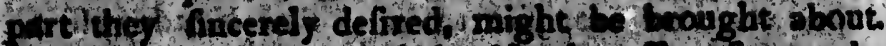

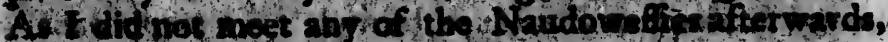

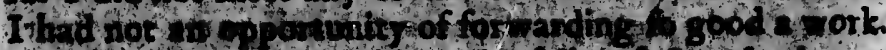

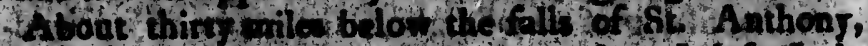

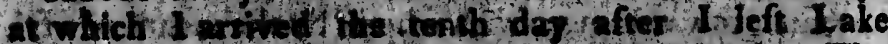

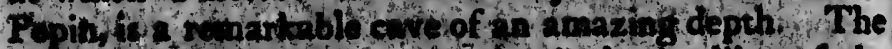
Ind:

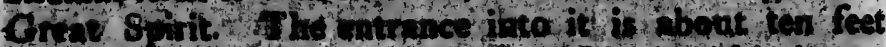

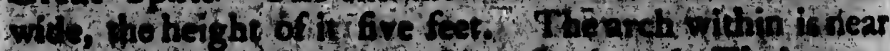

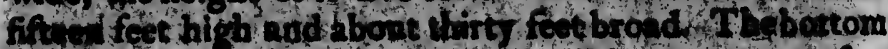

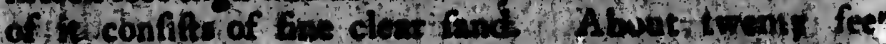
from the entrance betins a late, the nterso twheh is

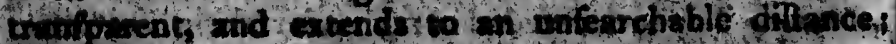

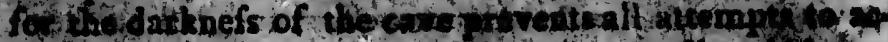

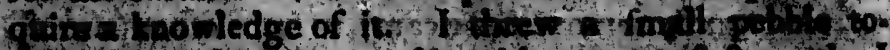

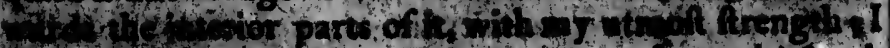

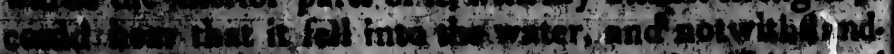

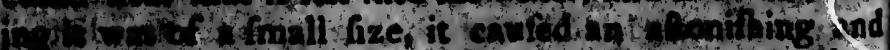

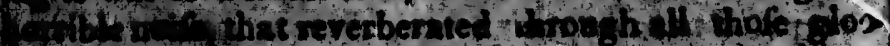
Dearly:co fieulty I. mannerist pofed ic penetrate found ne: bs afcend brink of

At a li rring-pla though $t$ Mtents and they alwo which the miget to Eitiof for 1

Ten mi 5t. J-ierm efotor, fal mentiand rive 8 thi from a fm by which heve dife niew, whe oppofite.

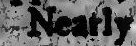
ar a now to Falls of Noven this place fyinit: Before the $\mathrm{A}^{2}+1$ Linte waccoth ad by the chiefs : b - Notrir 


\section{CARVERS TRAVEES.}

7 toule. for the he Nau. honors I

Chip. undithat 1e. The dhe el. of lhad betricen ad with. inether a geaer. inpriton, aej: met. efiof the artad an Wethe in eference an their betoput etwerds. darork. Anthons, eft Iake

th. The a) thef the ten feet initiviear Droteom cint feet wheh is antaces 7 thon $-15+10$ $4+1,+61$ itst thand hine tend ingrion 2.

Aphics which appented vesy meiens for time had Dearly covered them with mols, to that it was with dif. ficults I could trace them. They were cut in a rudo manner, upon the infide of che walls, which were com. pofed of a fone fo -xtremely foft that it might eafly be penetrated with a knife: a fone every where to be fourd neat the Mififippi. The care is onl - accefible b) afcending a narros, feep paffage, that lies near the brink of the river.

At a little dillance from this dreary cavern, is the bu. tring-place of feveral bands of the Naudoweflie Indians ? though there poople have no fixedrefidence, living in rents and abiding but a for months on one fpot, yet ther always bring the bones of their dead wa this place: thich thes take the opportunity of doing when the chiefs met to hold theiv icouncils, and to fettle all public af Eifr for the enfuing fummer.

Ten mile below the Falls of St, Anthons, the rive it. JEterre, called by the natives the Waddapavmen. efotor, fallsinto the Miffippi from the Welt. It is not mentiondd by tather. Hennipen, alchougli a large fais Hrea this omifion I conclude, mult hav procesded from a mall illand that is fitunted exactly at its entrance, by which the fight of it is intercepted. I fhould not he difcavered this river my felf had 1 not taken a riew, when I was fearching for it, frow the high lands Qppofite, which rife 20 a great height.

Weatly aver againh this river, I was obliged to leaje ar anoe, on account of the ice and ravel by land to th Falle of 84 Anthony, where I errited on the 17 th of November. The Miffifippi from the St. Pierre to this place, is rather more rappid than I had hitherto fert it; and without ilands of any confideration.

Before I. left my canoe 1 overtook a young prince of the tnebago Indians, who was going on an embac (t) of the bands of the Naudowefties Finding intended to take $a$ view of the Falls, he agreed to recenting me, his curiolity having been often exciitd by the accounts he had receired from enve of his chiefs : he accordingl, left his family (for the Indiar

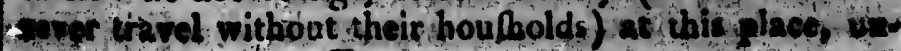
4. $\mathbf{2}$ 
Ger the eare of my Mohawk fervant, and we proceeder rogether by land, attended only by my Frenchman, to chis celebrated place.

We could diftinaty hear the noife of the water full fiften miles before we reached the falls; and $1 \mathrm{wa}$ greatly pleafed and furprifed, when I approacbed thi aftonilhing work of nature ; but I was not long at lib orts to indulge there emotions, my attention being cal led off by the behaviour of $m y$ companion.

- Thie prince had no foonet gained the point that over looks this wonderful cafeade, than he began with an 20 dible roice to addrefs the Great Spirit; one of whof places of refidence he imagined this to be He toll him that he bad come a long wäy to pay his adore tions to him, and now would make him the beft offen ings in his powet. He accordingly firt threw his pip into the fream s then the roll that contanied his tobacco after thefe, the bracelets he wore on his arms and wrifts next in ormament that encircled his neck, coithpofed d beads and wires; and at lat the enrorings from his ears in thort he prefented to his god, every part of his dref that was valuable ; during this he frequetly friote $h$ brealt with great violence threw his arms about and appeared to be much agitated.

All this while he continued his adorations and 2 length concluded them with fervent petitions that the Great Spirit would contantly afford us his protectio in our travels, giving us a bright fun, a blue $R, \mathrm{y}$ an clear, untroubled waters, nor would he leave the place till we had fmoked together in honor of the Great spit? it.

I was greatl. furprifed at beholding an inflance $d$ fo ch elevated devotion in fo young an Indian, and b fead of ridiculing the ceremonies attending it, as $I$ ob ferved m) fervant tacitly did, I looked on the pring With a greater degree of refpect for thefe fincere pof he gave of his piety; and 1 doubs not but that his of ferings and prajers were as acceptable to the uvikerfal Parent of markind as if they had been mads with greater pomp ar in a confecrated place.

Indeed, the whole condua of this youns pribes

we were to

ployed in

veren in fo

of the mol

on our ret

Whild I b

his unpol

parrifon b

mabitants.

var of the

'We Fal

ather Lo

Hed into

irt Eurap oody of mof ple out thire 300 yards 6. that $x$ puch hig traveller has made Falls of hereas $f$ known th: father If accounts, In the $\mathrm{x}$ fort feet 2 few cra half way rock, lyin pofition, $t$ and thirt ifl the ot then wit The co onos ezo bit comp fonnes 
proceeded iehmian, to

water full and 1 war oasbed thi ong at lib. being cal

that over. with an 20 of whor

He told his adore beft offer ow his pip vis tobacco: and writs othpoled d in his ears: of his dref frnose $\mathrm{h}$ about and

ions and ns that the proteptio ie for, and ke the plac Great spit

inflanse 0

an, and io it, as $I$ ob tho prine cere 2 bof hat hit of e uniterfal made with

sne amazed and charmed me. During the few dats we vere together, his attention feemed totally to be em. bloyed in yielding me every affittance in his power, 4 and tven in fo thort a time, he gave me invumerable proots of the molt generous and difinterefted friendship; fo that on our return I parted from him with $g$ reat reluciance. Whilt I beheld the artlefs, yet engaging manneis of this unpoliftied favage, I could not help drawing a cum. partilon berween him and fome of the more relined inabitants of civilized countries, not much, I own, in toor of the latter.

The Falls of St. Anthony received their tiame from ather Louis Hennipen, a Erench miffionary, who trap. alled into thefe parts about the year 1680 , and was the inft European ever feen by the natives. This amazing body of waters, which are above 250 yards over, form moft pleafing cattarat; they fall perpendiculariy a. bout thirty teet, and the rapids below, in the fpace of 300 yards mote, render the defcent conliderably greater 3 6. that when viewed at a diftance, they appear to be much higher than they teally are. The above mentioned travelles bas laid them down at above fixty feet; but he has made a greater error in calculating the height of the Falls of Niagara, which he afferts to be boll feet Whereas from ligter obferrations accuratel y made, it is well known that it does not exceed 140 seet. But the good Frther I fear too often had no other frundation for his accounts, than report, or, at beft, a light infpection.

In the middle of the Falls fards a fmall ifland, about forty feet broad and fomewhat longer, on which grow $a$ few cragged hemlock and fpruce trees, hnd about half way between this ifland and the eaftern fhore is a rock, lyin $\mathrm{g}$ at the very edge of the Fall, in $4 n$ oblique pofition, that appeared to be about five or fix feet broad, and thirt or forty long. Thefe Falls vary much from Ill the others I have foen, as you may approach clofe to then without any intervening hill or precipice.

The country around them is extremely beautiful. It - not an uninterrupsed plain, where the eye finds no relief, bit compoled of many gentle afeents, which in the Cinpmer are covered with the fineft rerdure, aind iate. 
Sperfed whit little groves, that give a pleaftng ratriets co the profpet. On the wholo, when the Falls are if. cluded, which may be feer at the diffince of forr miles, a more pleafing and piêturef cue view cannot, $f$ believ, be found throug the univer 5 , I could bave wilhed that I had happened to enjoy this glorieu fight at a more feafonatile time of the jear, whill the trees and hillocks were clad in nature's gayeft livery, as this mult have greatly added to the pleafure I received 3 bowever even then it exceeded my warmelt expectations. I have endeavored to give the reader as juft an idea of this en. chinting fpot, as pefible s but all defcrpition, whether of the pencil or pon, muft fall infinitely thot of the origivit:

At a little difance below the Falls fands a fmall il: and of about an acre and $a n$ half, on which grow a reat . Wimber of odk trees, every branch of which able to fupport the weight, whs full of exfle's nelts. The rea. Soa that buis kind of bitds refort in fuch numbers to this foot is, that ther are here fecure from the attacks cicher of man or leaf, their retreat being guarded by the rapids, which the Indians never autempt to pafs, Another rearon is that ther find a confant fupply of food for themfelves and their young, from the animats and fif which are dathed to pices by the lalls and crivtun on the adjucent thore.

Having futiffed my curiofity, as far as she eje of man can be fitisfied, I proceeded on, ftill accompanied by my Joung friend, till I had reached the river Si, Francis, netr fixty miles above the falls. To this rives father Heonipen gave the name of St. Francis, and this was the zrent of his travels gs well as minestowards the north welt. As the ferion wae fo advanced, and the weather fo extremely cold, I was not able to make fo many abfervations on there parts as 1 otherwife. Pould liave done.

It mighe lowever, perhaps, be, neceftary to obferve diat in the little tour 1 udade about the falls, after travel Uthy fourtecn miles,by the fode of the Mifrfippi, l cime to a river neariy twenty gards wile, which ran froin the norch eal, called Ruse Kliver. And the on soth of Nov.

ember

itielve

Francis irifitip. ninety) of fmali the dep

The

large in ferved $h$ bundanc above th lakes ca whic, mant $m$ turning!

The

thari the

pon and to the In relative rot 4 avi bie butrth and evet ins $80 \mathrm{c}$ the river interios ibatuc time the lo conve ite curre the Guils ifts in fre wid in er Goined 1 af ibe la pundred bes the crui mil thation 4 
variets is are in. or milles, a believ, be thed that t a more d hillocks huf have ever cién have enE this en. whether of the ori-

fradl ill: ch grow a hich able The rea. imbers to né artacks varded by tt to pafs, fupply of ic animals Talls and

he eye of ompanied. river St. this river incis, and restowards ed, and the i make 10 ife pould

to obcerve fier travel id, came to a froin the Soriof itor.

ember came to another termed Goofe River, abnut twelve yards wide. On the glt I arrived at the St. Francis, which is about thirty yards wide. Here the viffifippi itfelf grows narrow, being not more than ninety yards over, and appears to be chiefly corripoled of friali bsanches. The ice prevented me from noticing the depth of any of thefe three rivers.

The country in fome places is hilly, but without lange mouniains and the land is tolerably good: I ób. ferved here many deer and carriboos, fome ell, with a. bundance of beavers, otters, and other furs. A little above this, to the north eat, are a number of rnall lakes called the Thoufand Lakes, the parts about whick, though but little frequented, are the beft within ront miles, for hunting . as the hunter never fails of returning loaded beyond his expectations

The Mififippi has never becn explored higher ap than the the river St. Francis; and only by father Itennipen and myrelf thus fur. So that we are obliged folely to the Indians, for all the intelligence we are able to give relative to the more northern parts. As this river is not navigable from the fea for veffels of any confiderable burthen, much higher up than the furks of the Ohio, and oven that is accomplithed with great difficulty, ow. ins 80 the rapidity of the current, and the windiugs of the river thof fettements that may be made on the interio branches of it, mulf be indifputahly fecure from the attacks of any maritime power. But at tle fame time sle fettlers will have tlie advantage of beiny able to convey their produce to the feaports, with great facitity. the current of the river from its fource to its entrance into the Gulf of Mexico, being extremely favorable for doing dis in Imall craft " this might alfo in time be facilitz. ad in canials or fhorter cuts, and a comrinnication quined by water with New. York, Canada, stc. by war af the lakes. The forks of the Ohio are about nine huadred miles from the moth of the Miffifippi, follow: ang the courte of the river $i$ ind the Mifouri yro hum ched miles above thefe. From the latter it if abous twing rilas to the Illinois River, and from thit to the 18 
Ouifconflin which I have given an account of, about eight huindred more.

On the 25 thi I retnrned to $\mathrm{m}$ y canoes, which I had left at the mouth of the river St. Pierre; and here I parted with regret from my joung friend thie prince of the Winnebagues. This river being clear of ise, bF seafon of its louthern fituation, I found nothing to ob. Atruct my paflage. On the 28th, being advanced abnut forty milen, I arrived at a fmall branch that fell in to it from the north i to whichoas it had no name that I could diftinguifh it by, I gave my own. About forty miles. higher up I came to Forks of Verd and Red Matble. Rivere, which join at fome litule diftance before ther encet the St. Pierre,

The River St. Pierre, at its junction with the Miffifip. pi, is about a hunred yards broad, and continues that breadth nearly all the way I failed upon it It has a great depth of water, and In lome places runi very brift. ly. Abouc fifty miles from its mouth are fome rapids, and much uf

1 procesded up this river about two hupdred miles to. the country of the Naudowrefles of the plains, which lies a litile abore the Fork formed by the Verd and Marble Rivers; jnl mentioned, where a branch from thie fouth nearly foins the Miffouri River. By tho ace counts I recired from the Indians, I have reafon to be. lieve that the Biver St. Pierre and Millburi, though they enter the Milifippi treive hundred Miles from each. other, take their rife in the fame neighborhood 3 and: this within the fpace of $n$ mile.

The River St. Pierve's norchern branch rifes from sumber of lakes near the Mining monntains 8 and it is from fome of thefe. alfo, that a capital branch of the River Bourbon, which runs into.Hudfou's Bay, has in. fources:

Frnen the intelligence I gained from the. Naudowerlic Insiany, among whom I arrived on the $7 \mathrm{th}$ of De. cunber, ayd whoce languago I perfetly acquired dur. infs a refidence of five months, and alfo from the acecounts I afcerwards obtained from the Aftinipoils, who fireak the fume tongue, being a rovolied band of the

Mnutdo the At inhabit thefe of bive le contine Mlemfip giver of their foi the thre the latti

This

North led on $t$ rivers 9 and eac waters thoofian from th Bay of the Bay verfe up

It that red to a and hac of it $; t$ tainty w

It is. of New the time continue more int marica." I found Miffilap Woving 2testhen And the carons. fres the cins of 
of, about

ch I had 1 here I prince of. ice, by ig to obsed abont: 1 in to it et I could prty miles. 1 Marble. thej en.

Miffifip. bues that It has a ery brift. ie rapida,

miles to 1si which lerd and ch from The ace Con to be. though com each. odis and:

from and it is of the bas in.

ludower. of Dered dur. the uce. bite, who. of the
Muldowedies, and from the Killiftinoes, neighbors of the Atrinipoils, who fpeak the Chipewar language, and iphabit the beads of the river Bourbon i I fay from thefe nations, together with my own obfervations, I hite learned that the four moll capital rivers on the continent of North America, viz, the St. Lawreare, the Niffifippi, the river Bourbou, and the Oregon or the rive of the Wel (as I hinted in my Introduction) have their faurces in the fame neighborhood. The waters of the three former are within thirty miles of each vither: the latter, however is rather farther weft.

This thews that thefe parts are the higher lands in North A merica, andit is an inflance not to be parallel. led on the othor three quarters of the globe, that four rivers of fuch magnitude thould take their rife together, and each, after running fepatate courfes, difcharge theit. waters into different oceans at the diltance of two thoufand in les from their lources. For in their pafage from this 10 the Bay of sit Lawrence, ealt it to the Bay of M .j... outh ; to Hudfons Bay, north ; and to the Bay at the Straits of A nnian wefl, each of thefe tra verfe upwerds of two thoufand miles.

I thall here give $\mathrm{m}$ y readers fuch refledions as occur. red to me, when I receired this interefting information and had my numberlefs enquiries, afcertained the truta of it ; that is, as far sas it was poffible to arrive at a cer. tainty without a perfonal inveltigation.

It is well known that the colonies, particularly thuif of New England and Canada, are greatly affeeted, about the time their winter fets in, by a north weft wind, which continues for feveral moaths, and renders the cold much more intenfe there than it is in th: interior parts of A. merica. This I can, from my own knowledge, affertins I found the winter, that I paffed to the weitward of the Miffilippi, far from fevere; and the north weft wind Woving on thefe countries confiderable more tewper. 2to than I have often experienced it to be nearer the coaft. And that this did not arife from an uncertainty of the Corons, but was annually the cafe, I conelade, both frea the froll quantity of fnow that fell, and a toeal

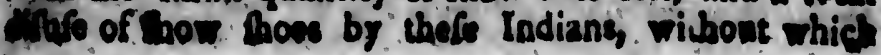


none of the more eafern nations can poffibly travel dura ing the winter.

As naturalifis obferve, that air refembles trater in $\mathrm{ma}_{2}$. ny refpeqs, particularly by often flowing in a compat body $;$ and that this is generally remarked to be with the current of large Areams, and feldom acrofs them, may not the winds that fet violently into the Bay of Mexico about the latter end of the jeat, take their courfe over the continent in the fame direction as the Mirmlfppi does s till meering with the notth winds (that from a fimilar caufe blow up the Bourbon from Hud(on's Bay) ther are forced acrofs the great lakes, down the current of the waters of the St. Lawrence, and united, commit thoferavages and occafion thofe fevere, winters, experi. enced in the before mentioned countries? During their progrefs over the lakes they become expanded, and conSéquently affeet a gieater traet of land than they other. wife would do.

According to iny feanty knowledge of natural phils. Cophy, this does not appear improbable. Whether it is agreeable to the lav s eltablifhed by naturalits to account for the operations of that element, I knot not. How. ever, the defeription here given of the fituation of thefe valt bodies of waiter, and their near approach to each other, with my own undigefted tuppofitions of their effet on the winds, may prove pethips, in abler hands, the means of leading to many ufefal difcoveries.

Un the 7th of December, I arrived (as I faid before) at the utmoit extent of $\mathrm{my}$ travels towards the wefl; where I met with a large party of the Naudoweflic In. diann, among whom $I$ relided feren months. Thefe conflituted a part of the eight bands of the Naudowesfies of the Plains, and are termed the Wawpeento ir. ahs, the Tintone, the Afrahcootans, the Muwhaws, and the Schians. The other three bands, whole names are, the Schianefe, the Chongoufceton, and the Waddapaw. jeltin, dwell higher up, to the welt of the river St. Pi. erre, on plains that, according to their account, are unbounded and probably terminate on the coalt of the Thelfic ocean. The Naudoweffe uation, when united, soing of more than two thoufand wartiog. The Af

Gaipoil

hundre continv

As 1

If reacl

Iobfer

but no

difleove

leaping

float as

perceiv

fight, $f$ country

Inoi

and the

that on

Aill cor

which ? glin co my feci in turni and $m o$ from th ofdered to cons folne of As 1 prefent tonither white? accordi every I Wo ha both ar of bein the pia commo they in Fror holpita wa fo 
drel dura

or in ma. compat be with is them, Bay of ir courfe Virifippi froma n's Bay) e current commit experiing their and con. e) other.

ral phils. ther it is oaccount Hor. 1 of thefe h to each their ef: ands, the

d Dafore). the voelt; welle" In. There audo wetpeentoir. saws, and atres are, addapaw. G St. Pi. t) are un. alf of the n" united, The Af:
Givipoils, who revolted from them; amount to about thros hundred, and league with the Killiftinoes, who live in a continual fiate of enmity with the other eleven bands.

As I proceedéd up the river St. Pierre, and had nearIf reached the place where thele people were encamped. I obferved two or three cances coming down the Arean; but no fooner had the Indians that were on board them, difcovered us, than they rowed toward the land, and leaping athore with precipitation, -left their canoes to. foat af the curtent drove them In a fev minutes 1 perceived foine others, who, as foon as they camo in fight, followed with equal fpeed, the example of their countrymen.

I how thought, it neceffiary to proceed with caution and therefore kept on the fide of the river oppofite to that on which the Indiams had landed. Howrever, I Atill continued my courfe, fatisfied that the pipe of pesce, which was fixed at the head of $\mathrm{my}$ canoe, and the $\mathrm{In}$ glin colors that were Alyiog at the fteras, would prove my fecurity. After rowing about half i mile furthes, in turning 2 point, 1 difcovered 2 great number of tents. and more-than a thoufund Indians, at a litile ditance from the fiore. Being now nearly oppofite to them, I ofdered my men to pull direelly over, as 1 was willing to convince the Indians by fuch a lep, that I placed: folne confidence in them

As foon as 1 had reached the land, two of the chiefs prefented their hands to me, and led me, amida the aftonilhed mujtitude, who had molt of them never feen a white man before, to a tent. Into this we entered, and according to the cuftom that univerfally prevails among every Indian nation, began to finoke the pipe of perce. We had not fat long before the crowd became fo great, boch around, and upon the, tent, that we were in dangor of being eruthed by in fall. On this we returned to the plain, where, having gratified the curiofity of the common people, their wonder abated, and ever after. thoy treated me with great reiped.

Ftom the chiefs I met with the moft friendly and bofpitable reception; which induced me, as the feifon - is fo far edvanced, to take up my refidence among 
then during the winter. To render any fay as come fortáble as polfible I firf endestored to learn their lan. guage. This I foon did fo as to make mycelf perfecty intolligible, having before asquired fome light know. edge of the langtage of thofe Indians that live on the back of the fettlements and in confenuence met with every accommodation their manaer of liviog would af. ford Nor did I vant, for fuch amurements as tended to male 10 long a period pals chectully away. I fin quently hunted with the $y$ and at other times beheld with pleafure theis resreations and paltimes, which I Thall defcribe bereafier.

Sometimes I fat with the chiefs, and whilt we fmol. ed the friendly pipe, ntertained them, in return for the accounte the gave me of their wars and excurfions; with a narative of my own adrentures, and a defoription of all tha battles fought between the. Englilh and French in A merice in mapy of which L had a perfonal thare Ther atways paid great attention to $m y$ decails and alsed many pertinent queftions relative to the Europern methods of making war.

I held diefe converfations with them in a great mear ure to prosure from them fome information relative so the chief puint I had conlantly in view, that of gaining 2 khoviledge of the fituation and produce, both of their own country, and thofe that lay to the weftward of thet. Nor was I difappoipted in my defigns, for 1 procured frot them much ufeful intelligence They likewif drew for me plans of all the countries with which thes - vere-acquainted b but as I entertained no great opinion of their geographical koowledge, I placed not mnch dependence on them, and therefore think it unneceflary to give them to the public. They draw yith a piece of burnt coal, taken from the hearth, upon the infide bark of the birch tree: which is finooth as paper, and anfwers the fame purpofes, gotwithftanding it is of a tellow call. Their fretches are made in a rude manner, but they feem to give us as juft an idea of a county, altiough the plan is not fo exas, as more experienced drafticmen could do.

- Iff the labitation of thete bofpitabie Indians the 
cone ir lan. reetiy. nowl. on the twith uld af: cended If fro. bebold hich I

fmol. for the irfions: ription French 1 Diare ls, and uropenin

it mear ative so. gaining of their. of then. rocured likewif ich the opinion te much beceltary -piece of de bark and ana yellow ber but. dithough. rafifmen inon the

titter end of A pril 1767 ; but did not part fiom them fos fovtal days, as I was accompanied on my journey if ne three hundred of them, among whom were ma. if elt, s, to the mouth of St. Pierte. At this feafon, thete binds annually go to the Great Cave, before What toned, to hold 2 grand council with all the other hands $f$ wherein they fettle their operations for the enfuitit year. At the fame tinse they carry with them their doad, for interment, botind up in buffaloes fins. Befides thole that ace wr ad me, others wem mocs before, and the relt $\mathbf{W}$. to t iv.

Never did I travel with fo cheerful and happy 2 con. pany. But their mirth met with a fudden and tempo. rary alloy from a violent form the orertook us one day on our paflage. We had juft landed, and were prepar. ing to fet up our tents for the night, when a heavy cleud overfpread the heavebs, and the molt dreadful thundors lightring, and rain iffued from it, that ever I beheld.

The Indisins viere greatly terrified, and tan to fuch fhelter as they could find; for only a few tents were as Jet erected. Apprehenfive of the danger that might chifu from fanding near anj thing which could ferve Sor a conduetor, as the cloud appeared to contain fuch añ uncommon quantity of electrical fluid, I took $\mathrm{mr}$ Aland as far as potible from any covering i chufing rathy to to be expofed to the peltings of the form, than to rective a fatal ftroke. At this the Indians were greatly fur. prifed,and drew conclufions from it not unfarorableto the opinion they already entertained of my refolution. Yet I acknowledge that I was never more affected in my life: for nothing carcely could exceed the terrife fcene. The pails of thunder were fo loud that they thook the eard: ad the lightning flathed along the ground in Areams of fulphur; to that the Indian chiefs themfliven although thetr courage in war is ufually invineible, could not belp trembling at the hotrid combuftion. As foon as the form was over, they flocked around me, and informed me that it was a proof of the anger of the evil fpirits, whom they were apprehenfive that they bad bighly of fended:

When we drrived at the Crent Cavenad the Indians 
had depolited the remains of their deceafed friends in the burial place that ftands adjacent 20 it; they held their great council, into which I was admitted,and at the fame time had the bonor to be inftalled or adopted a chief of their bands On this occation I made the following Ifeech, which I infert, to give my readers a fpecimen of the language and manner is which it is necellary to ad drefs the Indians, fo as to engage their attention, and to render the fpeaker's expreflion confonant to their ideas. It was delivered on the frft day of May 1767.

a My brothers, chiefs of the numerous and powerful Naudovreffies I rejoice that through my long abode with you, I can row fpeak to you (though after an im. perfét manner) in your own tongue, like one of your own children. I rejoice alfo, that I have had an opportunity fo frequently to inform you of the glory and povier of the Great King that teigns over the Englith and oth. er nations s who is defcended from a rerj ancient race of lovereigns, old as the earth and waters; whole fept fand on two great iflands, larger than any of you have ever fren, amidf the greateit waters in the world; whofe bead reaches to the fung and whofe urms eacircle the whole earth : the number of whole warriors arep. qual to the tices in the vallies, the fallis of rice in jon. der marfies, or the blades of grafs on your great plains: who hes hyridred's of canoes of his own, of fuch mazing bignets, thas all the waters in your coumtry vould not fuffice for one of them to fwim in s each of which have guns, not fmall like mine, which you fec e. fore jou, but of fuch magnitude, that a hund: ed of your loutelt young men Would with difficulty be able to car. if one. And thefe are equally furprifing in their ope. ration againt the great king's enemies when engaged in battle; the terror they carry with them, your language wants words to exprefs. You may remember the other day when we were encamping at. Wadawpaw. menefotor, the black clouds, the wind, the fire, the Atupendous noife, the horrible cracks, and the trembling of the earch, which then alarmed you, and gave you reafon so think your gods were angry with you is not unlike

Thêce at they are StPi me, in $t$ that thes dren anc remerib agatin to your goc that you mong 50 Bein return to I again fame mit ter, and who cam the fung, I aik you edge yout of the En opportun intentions

"i I cha Lere are boring $n$ ars again on you truth. "stid Ilimackin inte, $a$ ? hes mas eft fecur reat troe Tothis the mout? "Good jith the $x$ and of elieve an 
iends in eld their the fame chitef of ollowing cimen of ury tond. $n$, and to eir ideas.

powerful og abode er an im. e of your opportu. ad powts and oth ient race thole feet you have le world; is excircle iors aree. ce in yon. our great on, of fuch it country 11 each of you fee e. ed of your ible to cars. their ope. hen eaga. hem, your remember radautpaw. re, the Atu. embling of you reafon not unlike

thele are the warlike implements of the Englim, when the are fighting the battles of their great ling.

"Several of the chiefs of your bands have often told me, in times paft, when I dwelt with you in your tents, that they much withed to be counted among the chil dren and allies of the great king my mafter You may remember how of ten you have defired me, when I return again to my own country, to acquaint the great king of your good difpofition towards him and his fubjects, and that jou wifhed for traders from the Englifh to conie a. mong rou.

is Being now about to take my leave of you, and to return to $m y$ country, a long way towards the rifir $\mathrm{g}$ fun, I again do jou to tell me whether you continue of the fame mind as when I fRoke to you in council lafl-winter; and as the re are now feveral of rour chiefs here, Who care from the great plains towards the feting of the fun whom I haye nerer folke with in council before, I aik you to let me krow if you are villing to acknowl edge yourfelves the chlldren of my great mafter the king of the Englith and other nations, as I fhall take the firlt opportunity to acquaint him of your delires and good intentions.

is I charge you not to give heed to bad recorts, for there, at wicked birds Hing about nmong the neighboring nations, who may whifpor evil things in your. ars againf the Englifh, contrary 10 what I have told foi Jou mul not believe them, for I have told you the truth.

"And as $\mathrm{pr}$ the chiefs that are about to go to Mich. illimackinac, 1 toll take care to make for them and their Wite, a nrait road, fmcoth yates s, and 2 clear $\mathrm{ky}_{\mathrm{y}}$, that thet may $g 0$ there, and fmoke the pipe of peace, and eff fecure on a beaver blanket under the thace of the treat trce of peace. Tarewell !"?

To this fpeech I received the followir $g$ anfwer, from the mouth of the principal chief.

"Good hruther I I am now alcut to fp ": to jou ith the mouths of thefe my brother, chiefs of the eight and of the poverful naticn of the Naudomeflies. We lieve and are well fatisficd in the tsuth of every thing I 
you have told us about ycur great nation, and the great king our grcateft father f for whom we fpread this bed ver blanket, that his fatherly protection may ever reft ead fy and fate amongt is his children : your culors and your atms agtee with the accounts you have given us 2 bout your great nation. We defire that when you re turn, you will acquaint the great king how much the Naudowefles wilh tó be connted among his good chil. drea.

"You may beliere us when we tell gou that we will not open our ears to any who may dare to fpeak evil of our great father the king of the Englith and other na tions.

-We thank you for what you have done for us in making feace between the Naudoweffies and the Chip eways, and hope when you return to us again, that you will coriplete this good work, and quite difpelling the clonds that interrene, open the blue $\mathbf{k y}$ of peace, and caufe the bloody hatchet to be deep buried under the roots of the great tree of peace.

"We wifh you to remember to reprefent to our great father how much defic that traders may be fent to abide among us with fuch things as we need, that the hearts of ous young men, our wives and children maj be made glad. And may peace fublift betwen us, fo long as the fun, the moon, the earth, and the water thall endrite "Farewell I"

I thought it neceffary to caution the Indians againt giving heed to any bad repore that may reach them from the neighboring nations, to the difadyantage of the Englith, as I had heard, at different pkices through which l paffed, that emiffaries were fill employed by the French to detach thoo who were friendly to the Englifh, from their intere?. And I faw, myfelf, feveral belts of Wampum that had been delivered for this purpofe to fome of the tribes I was imong. On the delivery of each of thefe, a talk was held, wherein the Indians were cold dhat the Englifh, who were but a petty people, had Aplen that councry from their great father the king $d$ France, whilt he was afleep; but that he would foon awake, and take them again under his protection. Thef

I found ed to, b: which th

Whilt witis the gence $w$ of $S t$. A had recei mackina by in the thad not thoughts route, ac turned to ny good year, as it

As tite to renew make $m$ Lake'Su tage on $t$ from Mi doubted enough through Annian. find 1 en, as Is ment I $h$ conclufic

Burin them ent ed forme they sroo ing the my coun furnilhed or and voyage. In icon twenty 
the great d this tea. rer reft ea. colors and given us 2 . en you re. mach the good chil.

at we will eak evil of otber na

for us in the Chip. a, that you pelling the peace, and under the

our great be fent to ed, that the iildren maj ween us; $f_{0}$ the waters

ians againt reach them ntage of the es through loyed by the the Englib, eral belts of s purpore to delivery of ndians were people, had the king of would foon alion. Thet
I found were fent from Canada, by perfons who appzared to, $6 \mathrm{e}$ well affected towards the government under which they lived.

Whilf I tarried at the mouth o the rivar St. Pierre, witi there friendly Iridians, I endeavored to gain intelligence whether any goods had been fent towards the falls of St. Anthony for my ule, agreeable to the premife I had rereived from the governor, when I left Micibilli. mackinac. But finding from fome Indians, who palfed by in their return from thole parts, that this agreement had not been fuifilled, I was obliged to give up all thoughts of proceeding further to the north weft by this route, according to my on iginal plan I therefore re. turnet to La Prairie le Chien, where I procured as ma: nf goods from the traders I left there the precceding jeat, as they could fpare.

As thefe, hovever, vere not fufficient to enable me to renew my firt defign, 1 determined to endeavar to make my way acrofs the conntry of the Chipeways to Lake Superior; in hopo of meeting at the $\mathrm{G}_{1}$ and $\mathrm{Por}$ tage on the north fide of it, the tradets that annually $\mathrm{g}$ \% from Michillimackinac to the north welt: of whom doubted not but that I Thould be able to procure good enough to anfiver my purpole, and alfo to penetrate through thole more northern parts to the Straits of Annian.

And I the more readily returned to La Prairie le Chi. en, as I could by that means the better fultil the engagement I had made to the Naudoweffies mentioned at the conclufion of $\mathrm{my}$ fpeech.

Buring my abode with this people, withing to fecure them entirely in the interelt of the Englith, 1 had alvifed fore of the chiefs to go to Michillimackinac, where they would have an opportunity of trading, and of liear. ing the aocounts that I had entertained them with of my countrymen, confirmed. At the fame time 1 had furnilhed them with a recommendation to the governor and given them every direction neceffary for their voyage.

In confequence of this, one of the principal chiefs, and twenty fire of an inferior rank, agreed to go to the en. 
fuing fummer- This they took an uppurtunity of do. ing, when they came with the ref of their band to attend the grand council st the mouth of the river St Pierre. Being obliged, on account of the difappomtment I had jult been informed of to return fo far down the Mitk. lippi, $\mathrm{I}$ could from thence the more eafily it then on their journey.

As the intermediate parts of this river are much fre. quented by the Chipeways, with whom the Naudow, effes are continually at war, they thought it more pru. dent, being but a fmall party, to tal s the zdvantage of the hight than to travel with me by day, accordingly ro fooner was the grand council broke up than 1 took a friendly leave of thefe people, from whom I had re ceived innumeralle civilities, and purfued once more my voyage.

I reached the eaftera fide of Lake Pepin the fame night, wheie I rent athure and encamped as ufual, The naxt morning, when I had proceeded fome wiles further I perceived at a dítance before me, a fmoke, Which dengied wid lume dadians were near $z$ and in a

thort time difcovered tell or tweive tents not tar from the bink of the river. As I was apprehentive that this Was 2 party of the Kovers I had before met withi I knew. not what courfe to purfue $\mathrm{My}$ attendants purfuaded me to endeavor to pafs by them on the oppofite fide of the river o but as I had hithcrto found that the belt $w_{\text {as }}$ to enfure a friently reception from the Inding is to meet them boldty und without howing aty tokens of fear, I would by no means confent to their proporal. Infterd of this I croffed direç's over, and laveded in clie midh of them, for $b$, this time the greateft part of them vere Aanding on the Onore.

The firlt I accolfed were Chipeways inhabiting near the Ottowaw Lakes ; who received me with great cor diality, and gook me by the hand in token of friend. Ohip. At fome little diftance behind thefe food a chief remarkably tall and well made, but of fo fern an af pect, that the molf undaunted perfon could not behold him without feeling fome degree of terror. He feem. ed to have paffed the meridian of life, and by the mode

in whic that he bim in? with th ers : be and 100 tongue, Englifh hand I been fol pittol fri paffed c him.

I leat this was or the 8 Chipew: had alw when th on their fwotn t? its new is built

Find Atraty not fop up my forne d myfele fervast dian on he bebic in an $\mathrm{e}$ trich 6 any fut which the Ib

The fote ni the of long a 
$y$ - of do.

to aitend t. Pièrre. int I had the Mitr. them on

much fre. Naudow, pore pru. antage of cordiagly. an 1 took I had re. ince more

the fame as ufual, bme wiles is fmoke, and in 2

far from e that this ith, I knew. purfuaded lite fide of e belt was? ins, is to tolens of propofal. lavided in ef part of

iting sear great cor. of friend. od a chief in an af. not bekold He feem. 7 the mode in which he was painted and tatowed, I difcovered that he was of high rank. However, I approached him in a courteous manner, and expeeted to have met with the fame reception I had done from tie oth ars 3 but to my great furprife, he withheld his hund, and looking fiercely at me, faid, in the Chipeway. tongue, "Cawin nithilhin faganolh," that is, "The Englifl are no good." As he had his tomahawk in his hand I expected that this laconic fentence would have been followed by a blow i to prevent which, I drew a pittol from my belt, and holding it in a carelefs polition; paffed clofe by bim, to let him fee I was not afraid of him.is

I learned foon after from the other Indians, inat this was a chief, called by the French the giand Sauter, or the great Chipeway Chiet, for they denominate the Chipeways, Sauters. They likewife told no that lie had alvays been a fteady friend to that people, and when they deliyered op Michillimackinac to the Engith on their evacuation of Canada, the grand Sauter liad fworn that he would ever remain the avowed enemy of its new poffeffors, as the territories on which the fort is built belonged to him,

Finditg him thus difpofed, I took care to be cunfantly on nit guard whilt I ttaid, but that he might not fuppofe I was driven away by his frowns, I took up my abode there for the night. I pitched my tent at foune diftance from the Indiuns, and lad no focner laid myfle down to relt, than I was awaked by my French fervat. Having been alarmed by the found of Indian mufic, he had run to the outlide of the tent where he bebeld a party of young lavages dan cing tew $\mathrm{d}_{\mathrm{d}}$ us in an extraordinary manner, each carrying in his hand a torch fixed on the top of a long pole. But l hatl defer any furthet nccount of this uncommon entertaininent, which at once furprifed and alarmed ne, till I treat of the Indian dances:

The next morning I continued my voyage, and be. fote night reached La Prairie le Chien ; at which pláce the party of Naudowefies foon overtook me. Not long after, the Grand Sautor alfo arsived, and befor - 2 
the Naudoweffies left that place to continue their jour. ney to Michillimackinac, he found means, in conjunc. tion with fome French traders from Louifiana, to draw from ra about ten of the Naudoweffie chiefs, whom he prevailed upor to go toward thofe parts.

The remainder proceeded, according to $m y$ direc. tions, to the Englin fort; from whence I afterwards heard that they returned to their own country without any unfortunate accident befalling them, and greatly pleafed with the reception they had met with. Whilit not more than half of thole who went to the fouth. vard, through the difference of that fouthern climate from their own, lived to reach their abode. And fince I came to England I have becn informed, that the grand Sautor having rendeied himfelf more and inore dif. guifful to the Englifh, by his inveterate enmity towards ihem, was at length Ptabbed in his tent. as he encamped near Michillimackinac, by a trader, to whom I had re. lated the foregoing ftory.

I Thould have remarked, that whatever Indians hap. pen.to meet at La Prairie le Chien, the great mart to Which all who inlabit the adjacent countries refort, though the nations to which they belong are at war with each each other, yet they are ciliged to reftrain their ermity, and to forbear all holile asts luring their Aliy there. This regulation has been long eltabliphed 2 . mong them for their muktual contenirnce, as wistiout it ro trade could be carried on $I$ he fame rule is obferved alfo at the Red Mpuntain (atterwards difcribed) from whence ther get the ftone of which they make their pipes; thefe being indifpenfiule to the accommodation fievery neighboring tribe, a fimilar reftriction becomes nicedful, and is of /public utility.

'The river St. Ficrie, which runs through the territosicis of the Naudowetfies, flows through a inot delightiul country, abounding with all the neceffaries of life, Uhit grow fpontan:oufly; and with a little, cultivation it might be made to produce cren the luxuries of life. Wild rice grows hero is great abundance; and every purt is thlled with trees bending under their loads of fruits, fucl astplams, grapes, and applos the mead.

ows are bles; $v$ angelic: eggs. are emi be exce already and fu wovild $p$ habitan!

A lit: north fic towards Atone, of cribed: But wh as white was cru fand, of or, I an ftone itfe noble eff Near. is a mo? ftone, of In fome rather 's family u milk wh equal in clay that contrive, themfelv blue clisy with it: Sports an of peace with the Speeches When th 
beir jour. conjunc. to draw whom he

a) direc. fterwards without d greatly Whilit he fouth. climate And fince the grand inore 'dif. $y$ towards encarsped 1 had re.

ians hap. it mart to iés refort, c at war - reltrain ring tlicir blifued $x$. wistiout it s obferved ed) from rake their modation a becomes.

he territodelightiul $s$ of life, ultivation es of life. and every $r$ loads of he mead. ows are covered with hops, and many forts of vegita. bles; whilt the ground is ftored with aleful roats; with angelica, fpikenard, and ground nuts as large as hen's eggs. At a little ditance from the fides of the river are eminences, from which you have vieks that cannot be exceeded, even by the mott bentutiful of thofe I have already defcribed; amidn thefe are delightful gioves, and fuch amazing quantities of maples, that ther would produce fugar lufficient for any number of inhabitants.

A little way from the mouth of the river, on the north fide of it, Aands a hill, one part of which, that towards the Miffifippi, is compofed entirely of white Aone, of the fame foft nature as that $I$ have before def: cribed ; for fuch, indeed is all the ftone in this country. But what appears remarkable, is, that the color of it is as white as the driven fnow. The outwald part of it was crumbled by the wind and weather into heaps of fand, of which a bieautiful compofition might be made; or, I am of opinion that when properly treated, the tone itfelf would grow harder by time, and hive a very noble effect in architecture.

Near that branch which is termed the Marble River, is a monntain, from whence the Indjais get a fort of Atone, out of which they he' the bowls of their pipes. In lome of thefe parts is found a black, hard clay, or rather none; out of which the Naudowefles make the is fumily utenfils. This country likewife abounds with a milk white clay, of which china ware might be made equal in gonduefs to the Afiatic ; and alo with a blue clay that ferves the Indians for paint, with this latt they contrive, by mixing it with red iton: powdered, to paint themfelves of different colurs: IThole that can' get the blie cliy here mentioned, paint themfelves very much with it : particularly when ihey are about to begin their fports and paltimes. It is allo elteemed by them a nark of peace, as it has a refemblance of a blife $\mathrm{Asy}$, which with them is a fymbol of it, and made ufe of io their ipeeches as a figurative expretion to denote peace. When they with to thow that their inclinations are pa. 
cific towards other rribes, they greatly ornament both thernfelves and their belts with it.

Having concluded ny bufirefs at La Prairic le Chein, I proceeded once more up the Miffifippi, as far as the place where the Chipeway River enters it, a little be. low Iake Pupin. Here, having engaged an Indian pi. Iot, I diveficd him to fieer towards the Ottowaw Lakes, which lie wear the head of this river. This he did, and 1 arrived at them the beginning of Ju. 18::

The Chipeway River,at its junction with the Mifflip. pi, is about eighty yards wide, but is much wider as you advance into it. Near thirty miles up, it feparates into two branches, and l took my courfe through that which lies to the eaf wrard.

The country adjoining to the river, for about fixty miles is very level, and on its banks lie fine meadows, where larger droves of buffaloes and elks were feeding, than I obferved in any other part of my travels. The track between the two branches of this river is termed, the road of war butween the Chipeway and Naudowef. fie Indians.

The country to the Falls is almof without any tim. ber, and above that very uneven and rugged, and clpfels wooded with pines, beach, maple, and birch. Here a moft remarkable and afonifaing fight prefented itfelf to $\mathrm{my}$ visw. In a wood on the ealt of clue river, which was about three quarters of a mile in length, and its dipth further than my eye could reach, I obferved that every tree, many of which were more than fix feet in circumference, was lying flat on the ground, torn up by the roots. "This appeared to have beell done by fome extraordinury hurricane, that came from the weft fome years ago; but how muny I could not learn, as I found no inhabitunts near it, of whom 1 could gain informa. tion. The country on the welt lide of the river from being lef woody, had efcaped in a great meatupe this havoc as only a few trees were blown doin

Whar the heads of this liver, is a lown of the Chife. vays from whence it take its aname. It is fituated os

each fi fiderab fmall l. can fes ny of: of it ar plantati feemed I obleri felves in gree, th cording cate nat eating $\mathrm{t}$

In Ju of fmall to a hea I defcen fource: of virgin any othe

Here thon'ight would a ivas fo ? in it: $b$ which h abled to a few b In a tho which y This i accomp the curs

Iot crnpties from th and flas

'Ilie perios, with $w$ 
nt both

Chein, as the little be. ndian pi. w Lakes, This he of Ju.

Miflifip. er as you rates into at which

jout fixty meadows, feeding, is. The is termed, Jaudowef.

it any tim. gged, and ind birch. iprefented the river, ength, and I obferved tan fix feet nd, corn up ne by forme weft fome as I found $n$ informa. $f$ the river a a grext were blown

the Chife. fitualed on

aach fide of the river (which at this place is of no con. fiderable breadth) and lies adjacent to the banks of ira imall take Ihis town contains about forty houfes, and can fend ous upwards of one hundred warriors, ma; ny of whom were fine, lout soung men. The houfes of it are buil: after the Indian manner, and have neat plantations behiod them; but the inhabitants, in general feemed to be the naftieft people I had ever been among. I obferved that the women and children indulged them: felves in a cuftom, which though common, in fome de? gree, throughout every Indian aation, appears to be, according to our ideas, of the molt naufeous and indelicate nature ; that of fearching each other's head's and eating the prey caught therein.

In July I left this town, and having croffed a number of fmall lakes and carrying places that intenvened, came to a head branch of the river $8 t$. Croix. This branch I defcended to 2 fork, and then afcended another to its. fource Un woth thefe rivers I difcovered fereral mines of virgin copper, which was as pure as that found in. any other county.

Here 1 che to a fmall brook, which niy guide tho "ugt might te joined at fome diftance by freams that rould at length render it navigable The water at firft was fo fcanty, that my canoe would by no means fwim in it; but having ftopped up feveral old beaver dims, which had been broken down by the hunters, I was en. abled to proseed to me miles, rill by the conjunction of a few brooks, thefe aids beeame no longer neceffary. In a fhort time the water increafed to a mol rapid river, which we defcended till it entered into L ike Supericr. This river I named after a gentleman that delired to accompany me from the town of the Ottagaumies to the currjitig place on Lake Superior, Goddard's River.

To the $r$ eft of this is : nuther fmall river, which als crnpties into the tako. Ihis I termed Strawbstry River, from the great number of Arawberries of a good fize and Ravor that grew on its binks.

The counery from the Oitowaw Lakes to Inke Su. perior, is in gencrul very uneven and thickly covered with woods. The soil in tome pláces is tolerably good, 
in othen butindifferent. In the herds of the St. Croix and thd Ghipetwy Birets are exceeding fine Aurgebn. All the wiik etnes bat ween the Miffifppi and Lake su. perior is called by the Indians the Morchetto countfy, add k thought it moa juith named f forl' it being then

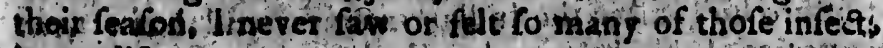
in my life:

Tha licter end of July I arrived, after having coafted throogh Well Bay, at the Grand Portage, which lies onithe north well border of Lake Superior. Here thofe who go on the north wet trade, to the Laker De Pluye, Dubpis ece carry over their canoes and baggage about aine nites, till tho' come to a number, of rmall takes, the waters of fome of which delcepd into Lake Stuperior, and athera into the river Bourbon. Lake Superior from Whet Bay to this place is bounded by toeks, except to. vards the foutli well part of the Baj where I firf enter. ad it thate it was tolerably invel.

At the Grand Poralge is a tmall baf, before the en. tranc of which lies in Il and that inter cepts the dreary and unnmeri uptar viec over the lake, which otherwif wauld have prefented nself, and males the bay ferenc and phealum fere I mict a large party of dhe Killilt. noe and A froipoil Indians, with thsir refpecive kings and their families Thos were come to this place in order to meet the tradera from Uichillimaktinas, who mate this their toad to whe noth wefl from them I feceired the following ascount of the tiakes that lio to the nontli well of Late Suparion.

Like Bourbon, the molf northern of thos yet difcor. oted, rucojudite name from forme. French traders tho accompanied a party of Indians to Hudfon's Bay fome years ago, and was this dohomihated by them in honor of the royal family of Prunce. It is compored of the waters of the Bourbou kiver, which as lave before obleryed, rifes a great way to the fouthwatd, not far from the northern heads of the Mifflippl.

This lake is abourteighty miles in letgth, dorth and fouth, and is nearly circular It his no rew large il. ands on it. The land on the ewlom fods is vert good, and to the foutb wat there art fome moantains, is wo

or othe

affes.

degrees

ofis: $B$ er then foind : me but or fithes fize, wh mer, wi delicien to betio timber Come mi I.ake Quinipi pofed of hundred been pro one hup fin of tude.

in whic

The 3 ron; the in? it The efpecial Miver $\mathrm{B}$ bis riv etilled

munck

lingor country dilo to Indian ather a lound 0 tak nins. esiloge 
Croix argeon. Le 3 : ountry, is then infect;

coafted iich lies. are thofe e Pluye, ge abbut all takes, Supêrior, ior from zeept to. oftenter-

the en. be dreary otherwifo

5 ference

Killiti. ve kings place in anc, who in them I iat lic to et difcor. iders who Bay fome a in honor ed of the ve before , not far

dorth and large in. eri good; avi is mat or oher parts thete are barren plains, bogs and mofl

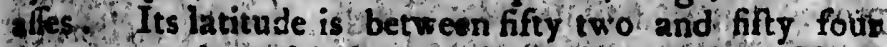
degrees north, ahd it lies nearly fouth weft from HudE $6 n^{2}$ ' Bay. As through is northern fituation the wieath. er ther is extremely cold, only a few anitnals are to bo foind in the country that borders on! it. The gave me but an irdifferent'socount bither of the beafts, birds. or fithes. There are indeed, fome buffalces of d f trith fize, which ate fat and 8 Qod about the latter end of fompher, with a fer moole and carriboo deer : howeter, this debijency is made up by the furs of every fort that are to be thet with in great pleaty round the lake. The tumber growing bere is chiolly fir, cedar, fprace, and fome maple.

At ake Winnepeek, on as the French write it, Lac Quinipiqne, which lies neareft to the foregoing, is compoled of the famie traters. It is in length absut two hundred miles north and fovith y tis breadth has nevies beor properly afcertaibed, but it is luppofed to be about oge hundred miles in its widef part. This lake is very firl of ilands o thefe are, however of no groat magnitude. Many confidorable riverf empty themfelves into

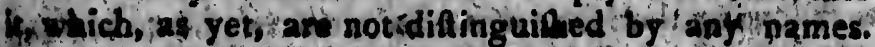
Thei maters are Rored with fill, fuch bs trout and ftir. roon, and allo with others of a imaller kind pectiliar to thes inkes.

The land on the fouth weft part of it is vety good, efpecially about the entravice of a large branch of the River Bourbon, which flowi from the fouth weft. $\mathrm{O}_{\mathbf{n}}$ this river there is a faetory that was built by the Ftench, called Fort la Raine, to which the traders from Michil, Hinactinac, refort to trade with the Affinipoils andk Kit: Hinnes To this place the Mabahs, who inhabit a conatry tiro huadred abd fifty miles fouth weft, come ilb to trade with thern, and bring great gintivilies of Indian corn, to exchange for knives, to th a thawky, tund ather articles. These people are fuppoled to dwell of fone of the brawehes of the River of the Weft.

Lake. Wianepiek has on the worth eift forne moup. thing and on the ealt twan r barred plains. The raple

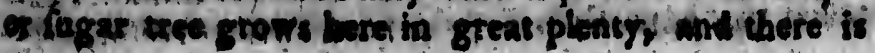


likewife gachered an umaring quantity of rice, thich proves that grain will flonith in thefe northern climtes as well as in warmer. Buffaloes, carriboo, and noofe déer, are numerous in there parts. The buffaloes of this coun. try differ from thofe that are found more to the fouth only in fize, the former being much finaller i juft as the black cattle of the northern parts of Great Britain differ trom Englifh oxen.

Op the waters that fall into this lake, the neighboring nations take great numbers of excellent furs. Soine of the fe they carry to the facteries and fettlements belong: ing to the Hudron's Bay Company, fituated above the entrance of the Bourbon Rives 3 but this they do with relustance on feveral accounts, for forme of the A finini. poils and Killiftinces, who tefualh traded with the company's fervants, told me, that if the could be fure of a conftant fupply of goods from Michillimackinac, they would not trade any whet ellet I bey thewed ine foste cloth and other articles tha the had purchired at Fud. fon's Bay, with which they rere much dilfatisfied, thinking they had beep greatly impoled upon th the barter.

Alloping that their accounts tere true, $I$ could not help joining in their opinion But this diffatisfaction might nrotably proceed in agreat weafure, from the ins trigues of the Chadian traders s for whilf the Hench vere in poffeflion of Michillimackinac, having acquired a thorough knowledge of the tride of the north welt countries, they were emplojed on that account; after the reduction of Canada, by tie Englith traders there, in the eftablifment of a trade with whiclwho' vere them: felves quite unacquainted Ore of the thetheds thicy took to withdraw thefe Indians from theit altactiment to the Hudfon's Bay Company, and to engage tha: gopd opinion in bebalf of their nevi employete, was is depreciacing on all occalions the Company tgoods, and magnifying the advantages that tould aris to them from trafticking entirely with the Canzdtan traders. In this they tow wall ouccesdedjand from this, coobilefs; did the diffatisfaction A A frapolls and Killatives ex.

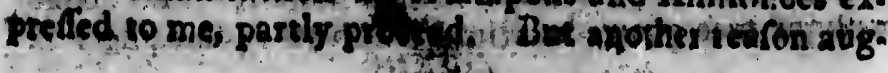

bented it the Hudf cook thei to go an noes they beaversit that thiel refide a: habit are tories 1 of wink dians $y$ mong th ders tha to trade which is by othe where $t$ baqt co Lac: their bin: fo caller banks: Lake li boul at anpeck. from ed breadib thefe of tupeds of the dlans fo bune.

This Superic vaters other 1 tom.

Lat Kaiay frotin : 
ice, thich $n$ clinates. noofe déer, this coun. o the Touth juft as the itain differ

eighboring Solne of ats belong: above the or do with the Aftini. th the com. e fure of a kinat, the ad me rothe red at Hiud: difitisfied, pon th the

could not Clatisfaction rom the in: he Herach $g$ ecquired worth wett t5; after the there, in vere them: hees ilicy ulactrmient gage tha

Bo, was is coodr, and to thend traders. coobitefs; (ivitoses ex. aronatig: nented it ; and this was the length of their journey to the Hodfcn's Bay faciories, which, they infurmed mo; sook them up three months, duing the fummer heats to go and return, and from the fmallnefs of their ca. noes they could not carry more than a third of the beavers they killed. So that it is not to be wondered at, that thele Indians thould wifl to have traders eome to refide among them. It is true that the parts they inhabit are within the limits of the Hudfon's Bay texritories but the Company muft be under the neceffity of winking at an encroachpoent of this tind, as the In. dians would without doubt proted the traders when a. mong them. Befides, the palfports granted to the tra. ders that go from Michilliadackinac give them liberty to trade to the north weft about Laks Superior, by which is meant Fort La Reine, Lake Winnepeek, or 2. hy other parts of the waters of the Bourbon River; where the Couriers de Boin; or Traders, may make it maq $\mathrm{f}$ convenient to refiad.

Lac du Bois as comtinotis termed by the French in their inaps, of in the Englith the Lake of the Wood, is to called from the mitliplicity of rood growing on its banks ; thech as oakei, pines, firs fpruce, erc. This Iake lies fill higher tpon a branch of tho River Bour. boly, and noarly tall from the touth end of Lake Win. appet. It is of great depth in forne places. Its length from caft to weft abolit ferenty miles, and its greaten breadth about forty miles. It has but few illands and thefe of no great magnitude. The flies, fowls, and quad tupeds that the foind near it; vary but little from thore of the other ttio lakes. A fer of the Killiftince Ine dians fome cime encemp on the borders of it to fifh and hune:

This Lake liet in the communication between Labe Superior, and the Lake Wirnetpeek and Bourbon. Ite paters are not effeemed quite fo pure is thofe of the oher lakes, it bavings in many places a muddy bot: com.

Lae La Pluye, fo called by the French, in Englioh the Kainy Lake, is fuppored to have acquired this name

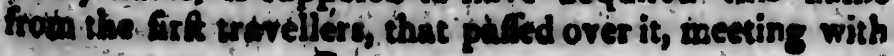
e. 
an uncommon deal of rain or, as fome have afirmed, from a milt like rain, occafioned by a perpendicular inater falt that empties itfelf into a river which ties to the fouth welt

This teate appears to be divided by an ittmalt, near the middle, into-two parts t the wef partis called the Great Rainy Lake, the eaf, the Litile Rainy Lake, as being the leat ditifion. It lies a few miles further to the eaftward, on the famie branch of the Bourbon; than the lest metitioned Lake In It io in genetal very Aredlow in it's depth. The brodedapart of it is mot midre than twenty miles; its leagth sinelviding böth telsout three hundred mile. In the thef part,tho witer indodi yzclear and good, and fone cetcellont fifh are taken in lt. $A$ grexit many, fowlis refort here in the fatt of the ycar. Hoofe deet are to befound in greate plenty rand lik wile the cartiboo, thole knin for bteeches or gloves ex. ceeds 'by fat any other 10 bo met with in North A meric2. Thethod on the borders of this Liakeis efteemed, in come placę, very good, but rather to a thic hly soler. ed with wood. Hete tefides a confiderabie, brand ot

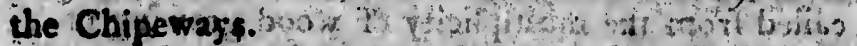

Lafivard from this thake lies feveral fmalt ones, which extend in a ftring to the great/car yirg place, and from thence tato Lake Supetios. Between thefelitcle Iake are feveral carrying places - shich render the trade to

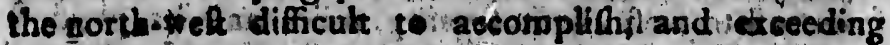

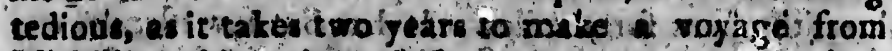

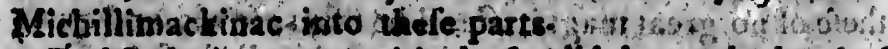

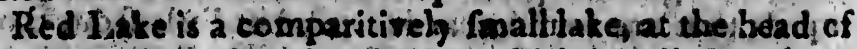
a branch of the Bourbon River, which is calted by fomo Red Kiver. Ii Ito form is reariy pound, and about fuxty miles in circumference. On one fide of it is a tolerable large ifanit, clofe by which ftalt ristr, innters lt

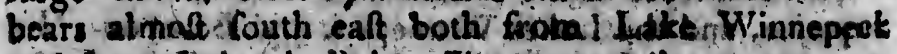

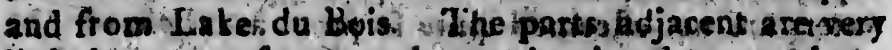

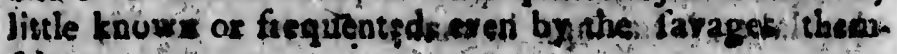
folves.

Not fur fromithic Loke, allute to the fopth tread is another, called White Bent Iuaksum hish is nedrit abour the fige of the lalt mentibed it The rintern thas com?

pore this the Miff remote 1 rather lo

A fev number ten miles Lakes: hinting. who hin canpes I

Havi molt no: ther ren Merico; thanthr north to foportsten is (Thef) Hakw fipacel defcribe it appea ine, that ur brok Hudfor Ocean. Then more a Mififin ipeek, b either dians, Nhe (ind be be $\mathrm{x}$ except And: they upon: carie? 
affirmed, sendicular b ties 10 $23<$ aft, neas alled the Lake, as further to bon; than 7 Aradlow giore than sout three odiyzelear infit. $A$ f the year. and lik: gloves ex. thi: Ameriefleemed, bly coler. el band of it bisitis?

ones, which and from lititle lakes 2 trade to etceeding affolf from oft is $b^{5}+x^{3}$ helbeladi of ad by tome chaut fixty 2 tolerabid intex a It Nimneppot itaresery at themp. 1. treks is urit abour baticom pafe this Lake are the moft nothern of any that fupply the Minfifippi and may be called with propriety is molt remote foutce. It is fed by two or three cmall sivers, or rather large broolis.

A few miles from it, to the fouth eaft, are a great number of Imall fakes, pone of which are, more than ten mileg in circumference, that are called the Thoufand Lakes- In the adjacent country is reckoned the fineft hanting for furs of any on this cortinent; the Indians who huit here, feldom returning without having their canpes loaded as deep as they ean frim.

Having juft before obferved that this Lake is the uto moft northern fource of the Militippi, I thill here further remark, that before this river eriters the Gulf of Mesico, it has run not lefs, through all its meanderings, than three thoufand miles, or, in a fraight line from north to fouth, about twenty degrees, which is nearly fporteen hustred Englith miles.

The If Iodians informed mor that to the norti wett of Lake Wingepere lies a nother, whofe circumfereace vak. J) etceede't any they had given nze an account of. They defcribe it as mu ch larger thin Iake Superior. But as it appears to be fo far to the north weft, I lhould imag: ine that it was nog a lates bat rather the Archipelago, Ut broken waters that form the com munication between Hudfon's Bay and the northern parts of the Pacific Ocean.

There are an in Guite number of Imall lakes, on the wore weftern pats of the weftern head branches of the Miffifppi as well as between thefe and Lake fwinneipeek, but nope of them are large enough to fuppore either of them to be the lake or waters mathe by the lo: dians,

The likerife informed me, that fome of the norti? era tranchis of the Miffouri and outhern branches of the St Piefre haves commustication with each other, except for a mile, pver which they carry their cinoes. And by what could leara from them, this is the road they take when their war parties make their excurfions uponthe Pawnes and Pawnownoes, nations inhabiting

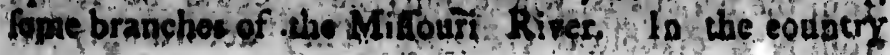


bolonging to thete penple it it fald that Mandrakes aro frequently found, a pecies of Koot folembling homan be ings of both fetes, and that thefe wre moite perfed than fuch as are difeovered about the Nile in Nether. Ethiopia.

$\Lambda$ little to the north weit of the herds of the Mifouri and St. Pierre, the Indians further told we, that there was a nation rather fmaller and whiter than the neighboring tribes, tho cultivate their ground, and (as far as I conld gather from their expretrons) in fome meafure the arts. To this account the r added that fome of the nations wh inhabit thofe parts that lie to the weft of the Shin. ing Mountains, have gold fo plenty among theth that they make their moft common utenfils of it: Thefe mpantaios (which I thall defcribe more particularly heteafter (diride the waters that fall into the South Sea from thofe that run into the Aithatic.

The people drelling near them are fippofed to be fome of the diferent tribes that were tributary to the Mexican kings, and who fled from thelr native country, to feek an affylum in thefe parts, about the time of the conqueft of Mexico by the Spaniards, more than two centuries 280 .

As fome confrmation of this fuppofition, it is remark. ed, that they have cholen the moft interior paits for their, retreat being Qill prepolfeffed with the notion that the fea coafts have been infelted ever fince with mon: llers romiting fire, and husling about thunder and light. ning 3 from whole bowets iffied men, who with unleen inftruments, or by the power of magic, killed the harm. lefs Indians at an afonilhing diftance. From fuch as thefe, their forefiaticrs (according to a tradition among them that (tili remaios unimpaired) fled to the retired avodes they now inhabit. For as they found that the floating-monfters, which had thus terrified them could not approach the land, and that thofe tho had defcend. ed from their tides did not care to malie excurfions to any confiderable diftance from them, they formed a ret. olution ta betake themfalres ro fome cpuntry, that lay from the fea coatts, where nily, they could he fecure fom fuch diabolied enemiss. Thet accordingly fet

wat with fettled $\mathrm{x}$ cluded

The: I Thave: fome Ar they are origina! great wi to tals

ore entiz it is rath their ap grants, tion.

There for the I rious alt they ate fible to: ation of

That thins ar ward, o the wat the $\mathrm{Cul}$ thence the fous the Sou or forts bet of $x$ South? compre

Ang the Kir from 2 ing fize. the fun ivery

This co be 
ales aro diman be per fea Nether.

Mifouri there was ghboring is. I conld $c$ the arts. o nations the Shin. hem that t. Thele rticularly South Sea

ed to be arf to the - country. ime of the than two

is renark. parts for otion that with mon: and lighi. ith undeen the harm. Jich as on among he retired d that the em could 1 defcendurfions to ned a rel. , that lay be fecure lingly fet wet with their fimilies, and after a long peregrination, fettled thencelves near there mountains, where they concluded they had found a place of perfect fecurity.

The Winnebagoes, dwelling on the Fux River (whom Thave already trented of) are likewife fuppofed to be fome Arolling band from the Mexican countries. But they are able to give only an imperfect account of their original, fridence. Ther fay they formetl came a great way Lom the wetward, and were drivon by wars to take refuge among the Naudorieffes; but as they ere entirely igoorant of the urts, of of the value of gold, it is rather to be fuppofed, that they were driven from their ancient fettlements by the above mentioned emigrants, as they palfed on towards their prefent habita. tion.

Thefo fuppofitions however, may want confirmation; for the Imaller tribes of Indians are fubject to fuch vatious alterations in their places of abode, frim the wars they are continuall r engaged in. that it is almolt impor: fible to a fertin, after half a century, the original fituetion of anj of them.

That range of muluntains, of which the Shining Mountains are a part, begins at Mexico, and continuing northward, on the back or to the ealt of California, feparate the waters of thofe numerous rivers that fall either into the Gulf of Mexico, or the Gulf of California. From thence continying their courfe Bill north, ward, between the fources of the Miflifippl and the rivers that run inte the Sourh Sea, they appear to cad in ubout forts foren or forty eiglit degrees of porth latitude; where a number of rivers arife, and empty themfelves either into the South Sea, inco Hudfon's Bay, or into the vaters that communicate between thefe two feas.

Among thefe mountains, thofe that lie to the wel of the Kiser St. Pierre, are called the Shininy Mountains. from an infinite number of chrytial ftones, of an ama:ing fize, vith which they are covered, and which, when the fun thines full upon them, fpartle fo as to be feen at - ver s great diftance.

This extraordinary range of mountains is calculated is be mere than three chouland rilles in length, withpat o 8 
any vet confierable intervals, which I believe forvales any thing of the kidut it the other quarters of th ythis: Probably in future ages they may be found to contain more riches in their bbwels, than thofe of livdoftat and Malabar, or that are prodiced on the golden codt of Guinea, nor will I excopt event the Perivian mithes. To the weft of thefe mountains, whet explored by fu. ture Columbufes or $\mathbf{R}$ aleighs, may be fotind other lakes; tivers, and countries, full traught with alr the nectfaries or luxuries of life ; and where future genetations maj

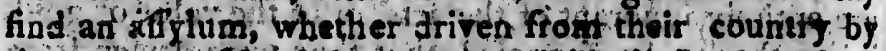
the ravages of tawless ttrants-ortof rellgibus? perfecu.

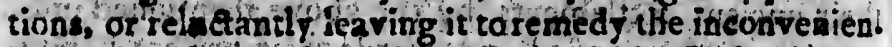
ces ariling fron a fuperabuindant increaf of inliabitants; whether, I lay, impolled by thefe, or allured by hopes of commercial advankes, there is little doubt but their expetations witl be fully gratted in thefe rich and un. exhaulfed climes.

But tó return to the Stinipoils and Killiftinocs, whom Ileft at the Grand Portage, ard from thom I received the forcgoing account of the lakes that lie to the north réft of this pláce.

I'he traders we expected being later this feafon than whal, and our numbers rery confiderable, for there were more than three hundred of us, the liock of provifions we had brought with to was tearly exhauled, and we waited with iampatrence for their arrival.

One day, whill we were all exprefling our willes for this utelirabevent, and looking from in eminence in ilapes of feeing them come over the lake, the chief priet belonging to the band of Kitliftinoes, old th, that be wauld endeavor to obrain a conferetee with the Great Spirit, and know from him when the traders would arrive. I paid little attention to this declaration, flippofing that it would be prodictive of fome jurggling I. ju jut fiffictently covered to deceive the ignurant Gdints. Wut the kifg of that tribe telling me that this wa chietty uhdertaken by the prielt, to alleviate no tarizWety, and at the fame time to convince me hour minch in. terel he wad with the Great Spirit, I thought it necelo

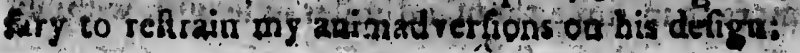


Crpirtes ado ghos: contaia oftat and codtit of in mities? ¿d by fu. her lakes; ociceffaries toris maj ouritis by 3. perfecu. sớnveäien. Labitants: hopes of but their arand un.

os, whom I receited che north ins:

dfon than for there of pro. oxhanked, al:

willes for jinence in triê prien that bo with the e traders claration, jungling. iguverant ethat this: my ât. thuch in. it neceltits
The following evening fas fixed upon for this fpiritat conference. When every isthing had been properly prepared, the kvig cante to-me andled me to a cipacious tent, the coverng iof wizch was drawir top, : $\{0$ as tu render what was tranfating within, vilible to thofe, who

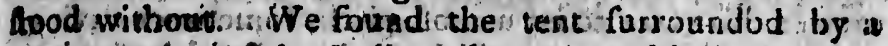
great numborl of the lindiaris, but we readily giaiged adw miff in, and feated ontelves on 1kims lad on the ground for that parpole.

- In tho centre I Iobferved that there was a place of an oblong Thape, iwhich was compofed of fakes luck in the ground, with intervals betweeil, fo asto form a kind of ebeft or coffin; hargo enough to contain the body of z man Thefe were of a middle fize, and placed at fich 2 diftance from ouch ouluer, that whatever las within thing was readily difcerned. The tent was perfeety il laminated by a great number of torches made of iplint. ers cut from the pine or birch tree, which the Indians leld in their hancts.

In fet minutes the prief entored; then an amaz. ing large elk's Akin heing fpread on the ground, jult at $m$ foet he laid himfelf down upoh it, after having fript himfelf of every gamment except that which he wore clofe about his middle. Being now proftrate on his back, he artet luid hold on one fide of the foid, and folded ir over bin; and then the other, leaving only nit head uncoter d. This was no founer done, than two bef the young men who foodr by, trok about fort yards of Arong cordi made alfo of an elk's liide, and rolled it tight round his body fo that he was complese. H, fwathed within the okint Being thus bound up like an Egyptian Murmmy, one tor $k$ him by the heels, and the other by the herd, and lifted him over the pales into the enclofure. 1 could ald now discern him as plain as I had hitherito donej and I luok care not to tuan my eyes d thotherit front the object before me, that I wight the more teadlly detect the a itifice; for fuch I doubted not but ifut it would tuta ont co be.

The pricfthad nut iahi in this fituation more than $\alpha$

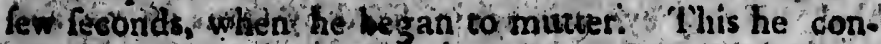

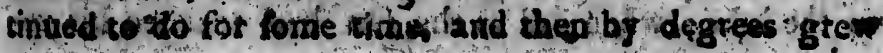


louder and louder, till at length he fpoke articulately, however, what he uttered was in fuch a mixed jargon of the Chipeway, Ottowaw, and Killiftinoe languages, that I could underftand but vety little of it. Having continued in this tone for a confiderable while, he at lait exerted his voice to its u molt pitch, fometimes raving, and fometimes praying, till be had worked himfolt into iuch an agitation, that lie foamed at bis mouth.

After having remained neat three quarters of an bour in the place, and continued his vociferation with unaba. ted vigor, he féemed to be quitc exhaufted, and remain. ed fpeechlefs. Bnt in an inftant he fprung upon his feet, notwithstanding at the time he was put in, it appeared im. politie for him to move either his legs or arms, and that king off his covering, as quick as if the bands with which it had been bound were burned afunder, he began to ad. drefs thofe who ftood around, in a tirm and audible voice. "My brothers," fai. 1 he, "the Great Spirit has deigned to hold a talk with his ferrant, at $m$ y earneft requef. He has not, indeed, told the when the perfons we expeet, will be here, but to morrow, foon after the fun has reached his higheft point in the heavens, a canoe will ar. rive, and the people in that will inform us when the tra. ders will come."

Having faid this he ftepped ont of the enclofure, and after he had put on his robes, difmiffed the alfembly. I own I was greatly aftonihed at what I had fren : but as I oblerved that every eye in the company was lixed on me with 2 vien to difcover my fentimeats, I carefulo Iy concealed every emotion.

The next day the fun thone bright, and long beford noon all the InJians were gathered together on the ems inence that overlooked the lake. The old king came to me and afked me, whether I had to auch confidence in what the prieft had toretold, as to join his people on the hill, and wait for the completion of it i I told him I was at a lof what opinion to form of the prediction, but that I would readily attend him. On this we walk. ad together to the place where the others were af bled. Every eye was again fixed by turns on me and on the lake; when jus as the iun had reached bin se.

aith, agr came aro Indians t thive, ar intereft $\mathrm{t}$ Spirit

In lefs I attends: on board ed all tor their inva we did, $n$ dings the the India However quired of traders? them a fe here the 1 Is arrived mire par by this e of their Aranger.

This A marks of tinclure cumftanc nature: from eith Self a ce thought $\mathrm{i}$ this Ido readers, 0 minds, bu they $p$ !e? I hine part of : Naudowe ed grier ancious o 
iculately d jargont anguages, Having he at lail es raving, mfelt into h. of an hour th unaba. id remain. on his feet; pesired im. s, and thas with which gan to ad. lible roice. as deigned t requet. we expect, he fun las 106. will ar. ion the tra.

lofure, and Jembly. I foen : but was ifixed , I careful.

ong beford on the ems ig came to confidence people on told bim prediction, is we walk. rere alem. on me and bed his seo aith, agreable to what the prieft had foretold, a canoe came around a point of tand about a leage dif ant. "The Indians no fooner bcheld it than they fot up an univerfal thrut, and by their looks feemed to triumph in tho intereft their prief thus evidently had with the Great Spirit

In lefs than an hour the canoe reached the fhore, when I attended the king and chiefs to receive thofe who vere on board. As foon as the men wero linded, we walked all together to the king's ter, when, according to their invariable cuftom, we bogan to Imoke; and this we did, notwithltanding our impatience to know the tidings they brought, without alking any queltions ; for the Indians are the molt deliberate people in the world. However, after fone trivial converfation, the ling enquired of them, whether they had feen any thing of the traders? The men roplied, that they had parted frow them a few days bofore, and that they propofed being here the fecond day from the prefont. They according. is arrived at that time greatly to on fatiofadion, but mire particularly fo to that of the Indians, who found by this event the impurtance both of their priel and of theis nation, greatly augmented in the light of a Aranger.

This fory 1 ackoowlejge appears to carry with it marks of credulity in the relator. But no one is lefs tinclure 1 with that weakne's than myfelf. The cir: cumftances of it I own are of a very extraordinary nature i however as I can vouch for their being free from either exaggeration or mifreprefentation being $m y$ : felf a cool and difpalfiraate obferver of them all, I thought it neceffiry to give them to the public. And this I do without wilhing to millead the judgment of my. readers, or to make any fuperRitious impreflions on their minds, but leaving them- 10 draw from it what conclufions they pleafé.

I have already obferved that the A finipoils with a part of whom I met here, are a revolted band of the Naudowetities, who on account of fome redl or imaigin. ed grievances, for the Indians in general are very te. ancious of their libetty, had feparated themfelves from 
their cauntrymen, and fought for freedom at the ex. porice of their eafe. For the country they now inhabit about the borders of Ijake Winnepeek, being much further north, is not fo fertile or agreeable as that they. - have relinquifhed: They Rill retain the language and manners of their former affociates.

'The Killitinoes, now the neighbors and allies of the Atfinippits, for the alfo dwell near the fame lake, and on the waters of the River Bnurbon, appear to rave been qriginally a tribe of the Chipiways, as they fpeak their I gunge, though in a different dialect. Their na. tion contifs or about three or four hundred warriors, and they ftem to be a hardy, brave people. I have al. ready gived an account of their country when I treated of Lrike. Winnepeek.'As they refide within the lim. its of Hudfor's Bay they generally trade at the fatto. nies which belong to that compatiy, but for the reafopi mentiosed betore, the $\mathrm{f}$ frequenily come to the place whete Ihanperited toijoint thein, in order to mset the traders frnm iMichillimackinac.

If The andiets I that felt on account of ithe traders' de. lay, was not mucb alleviated by their arrival. I again fotind my expestations difappninted, for. I was not able to procure tlie goods I wanted from any of them.. I was therefore obliged to give over my defigns, and rc. tuin to the place from whence I firft began my extenfive citcuit: I accordingly took leave of the old king of the Killittinoes, with the chiefs of both batids, and de. parted. This prince was upwards of fixty years of age, tall and flightly made; but he castied himfelf very cich He was of a courteoughiaffable difpofition, and treatled pmeri as did bll the chiefs, with great civility.

Tobferved that this people Aill continued a cultom, thest upprared to hare bcen univerfis before any uf them became acquainted with the manners of the. Europeans, that of coimpliminting Arangers with the company of their wites $f$ and this is not only pradifed by the lower ranks, but by tho chite chemielvesy, who efecm is the greatalt proof of courtefy they can give a ftranger.

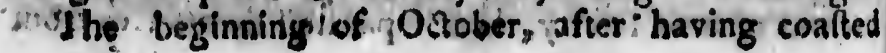

round th arrived a St. Mari of $i t$.

Lake from its $r$ being fuf valt cort: of Amer freh wivat! to the $F_{\mathbf{r}}$ I believe. extent of: dredi:

After I Bay. I co. and eal in of that ex ten igroui 3 bed of 1 in ight, I Fards of fone: at $\mathrm{t}$ ppeaned ras as py das if it polfible to ththe rocl were elap b) eito be I difcon onperiy he mourb of the wa riggoated Lown $\mathbf{a}_{\text {il }}$ pater dra ad the fa ces:

The fis: rom thel 
t the es. w inhabit ing : much that they. uage and

lies of the lake, and $r$ to rave they fpeak Their na. 1 warriors, I have al. n I itreated the lim: the facto. be reafoni the place mest the

raders' de. l.i. I again is not able f them. . I ins and rc. by extenfive d king of is, and de. ty years of imlelf very difpofition, th great ci.

1. cuftom, any of them Europeans, company of y the lower n eleem is a-Aranger: ing coalted round the north and eait borders of Lake Superior, I arrived at Cadot's Fort which adjoins to the Fulls of: St. Marie, and is fituated near the fouth weft corner of it:

Lake Superior, formerly termed the Upper Iake, from its northern fituation, is fo called on account of its being fuperior in magnitude to any of the l.akes on that vaft cortinent It might jultly be termend the Cafpian of America, and is fuppuled to be the larget body of frefh water on the globe. Its circumference, according to the French charts, is about fifieen ihundred $\mathrm{m}$; but 1 believe that if it was corlted round, and the atmoft dxtent of eveny bay taken, it would exceed fixtee hun-: dredis

After I entered it from Goddard's River on the ateft Bay, I coalted near twelve hundred miles of the north and ealt fhores of it; and ubferved that the greateft part of that extealive tract was bounded by rocks and uneren igraund Il 1 be water in general appleared to lie an abed of rocks. When it was calor anditbe fun thpue itighit, I could fit in ms canoes where the depth was up. vards of tix fathoma and plainty fee huge piles of ione at the battom of different Chapes, fome, of which

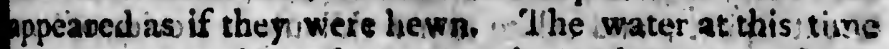
was as pure and tranfpatent as air gad $m$ y canoe fegms ad as if it hung furpended in that element. It was inepolfible to look attentively through this limpid medium. tothe rocks belon, withoux finding, before many minutics were elapfed, you wead fwim and jour eyer no long is: ble to behold the dazaling fcene.

l difconeredialfo byj accident unother extraoxdisaxy. poperify in the waters of this lake though ir was in the month of . July thas I palfed ovevitt, and the turface of the water frum the heat of the fuperambieot air, imgregeated withino:Imall degree of wumth, yet on.jelting lown a cup to the depih of abouk a facho min the pater drawnifrom thence, wis fo exçeftively cold, that it had the fame effes when recelved into the asoush is

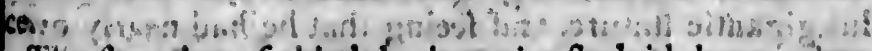

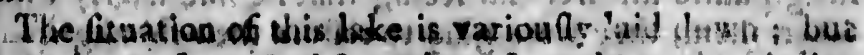
rom the moll oxpat obforvations I cousk laidke, it lies. 
Detween forty fix and fifty degrees of nonth lattitudy and between eighty four and ninety three degrees of well longitude, trom the meridian of London.

There are many illands in this fake, two of which ate very large; and if the land of them is proper for cultio vation, there appeari to be fufficient to form on each cosfiderable province; efpecially on Ifle Reyal, which cannot be lefs than an hundred miles long, and in many place forty broad. But there is no way at prefent of accertining the exact length or breadth of either. Even the $\mathrm{f}$ ch, who always kept a fmall fchooner on this lake, whilt they were in poffelfion of Canada; by which they could have made this diffovery, have only acquired a flight knowledge of the external parts of thefe illands; at leat they have never publithed any account of the ioternal parts of bein, that I could get any intelli: igence of.

Nor was I able to difcoter from any of the converf: tions which I hald with the neighboring Indians, that they had ever thade apj futtoments on tbem; or evell Ianded there in their humting excurfions. From what I could garber by their difcoburfe, they. fuppofe them to have betn, from the firf formation, the refidence of the Great Spirif i and relate thany ridiculous ftories of en. chantment and thagical tricks that had been experienced by fuch as were obliged tivough frefis of weather to taks Delter on them.

-: One of the Chipeway chiefs told the, that fome of their yeople being once driven on an iland of Maurz pas, which lies towards the north ealt part of the lake, found on is large quavtities of a heary, thining, yellow fand; thac from their defeription mul have been gold doff. Being fructs with the beatiful appearance of it ib the morning, whon they reentered their canoc; thes) attempled os bring fome away is bot a fpirit of an amaz ing fize, accerding to their account, fixty feet in height Arode in the water after them, and cocoser nded the $m$ bo deliver buck what thio had roken awn p. Territied a his gigantic lature, and feeing that he had nearly over? taken them, they were slad to reflone thalr fhining treaf

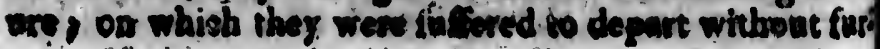

her mole as evèr 1 coatt.

Lories of

The co perior is being inte but little Iuw : an its thore. abundanc ine flavo aring 9 in the fat But th refemblin lighter $\mathrm{r}$ cious tha ing that : 2 thrub c that of $t$ planted is prove a in Tro lake, on Nipegon nipegon. habiting ed the $M$ vated to thor: cain that bay, by this $p$ mackinad reign of their for in them thefe we prefent ti ortune, tere. 
lattitude, zes of well

which are - for cultion each 1 al, which dd in many prefent of her. Even ner on thit b) by which Is acquired se iflands; buint of the any intelli:

te converfas idians, that $x$, or evetil rom what I ife them to ence of the ories of enexperienced ther to :ake

lat fome $\alpha$ of Maura: of the lake, ing, yellow - been gold arance of $i t$ cancee, they of an amax. et in height ideo ithem id Terrified a: nearly overo aining treaf withoout furs

ther moleftation. Siace this incident, no Indian that has ever heard of it, will venture near the fame haunted coaft. Befides this, they recounied to me many other hories of thele illands, equally tabulinus.

The country oin the north and ealt parts of Lake Su. perior is very mountainous ald barren. The weather being intenfely cold in the ivinter, and the fun liaving but little power in the fummer, vegetation there is very Juw : and confequently but little fruit is to be found on its thore. It howevel produces forre few fpecies in great abundance. Whortieberries, of an uncommon $f$ and ine flavor, grow on the mountains near the la.e in a. mazing quantities; as do black currants and gockerrics in the fame luxuriant manner.

But the fruit which exceeds all the others, is a bery refembling a raberry in its manner of growth, but of a lighter red, and much larger; its talte is far more deli. cious than the fruit I have compared it to. notwithatind. ing that it is fo bighly elteemed in Europe : it grcus on 2 thrub of the nature of a vire, with leaves fimilar to that of the grape and I am perfuaded that was it tranf. planted into a warner and more kindly climate, it would prove a moft rare and delicioul fruit.

Two very large rivers empty themfelves inte this lake, on the nortli and north ealt fide; one is called the Nipegon River, or, as the French proncunce it, Aliznipegon. which leads to a band of the Chipevays in. habiting a lake of the fame name, and the orher is term. ed the Michipiconton Kiver, the fource of which is fit. uated towards Jam 'Bay, from whence there is but a thor: carriage to another river, which empties itfeif into that bay, at a fort belonging to the company. It was by this paffage that a party of French from Michilli. mackinac, invaded the fettlensents of that fociety in the reign of y'ueen Anne. Having taken and deltrosed their forts, they brought the cunnon which they four:d in them to the fortrefs from whence they had iffued; thefe were fmall brals pieces, and remain there to the prefent time; having. through the ufial revolutions of cortune, relurned to the poffiffion of their forner niaf.' iere. 
Not far from the Nipegon is a fmall river, that juh before it enters the lake, has a perpendicular fall from the top of a mountain, of more than fix hundred feet. Being very narrow, it'appears at a diltance like a white garter fufpended in the air.

A fer "Indians inhabit round the eaftern borders of this lake, fuppofed to be the remains of the Algonkins, who formerly poffelled this country, but who have been nearly extirpated by the Iroquois of Canada. Lake Su. perior has rear forty rivers that fall into it, fome of whid Ae of confiderable fize. On the fouth fide of it is a resuarkable point or cape, of about fixty miles in length, cal!ed Point Chegomegan. It might as prop. erly be termed a peninfulit, as it is nearly feparated from the continent, on the eaft fide, by a narrow bay that ex. tends from ealt to welt. Canoes have but a fhort por. tage acrofs the ifthmus, whereas if they coaft it round, the voyage is more than an huridred miles.

About that dittance to the welt of the cape juft de fcribed, a confiderable river falls into the lake, the head of which is compofed of a'great affertolinge of fmall freams. This river is remarkable for the abundance of virgin copper that is found on and near its banks. A metal which is met with alfo in feveral other places of this coaft. I obferped that many of the fmall iflands, particularly thofe on the eaftern thores, were covered with copper ore. They appeared like beds of copperal, of which many tons lay in a fmalt fpace.

- A company of adventurers from England began, foon afrer the conquelt of Canada, to'ring away fome of this : metal, but the difracted fituation of affairs in A merica has nbliged them in relinquith their fcheme. It might in future timrs be'rande a very advantageons trade, as the nictal, which colts nothing on the fpot, and requires but little experiee to get it on Loard, could be convejed in boats or canues ils ough the falls of St. Marie, to the lith of St: Jofeph, which lies at the bntcom of the Straits vear the entrance into Lake Huron; from thence is might be put on board larger iveffels, and in them tranf. portud acrofs that 'ake to the falls of Niagasa 8 then being carried by land acrols the portage, it might bo

converes The chea may be $\mathrm{f}$ that is ne coalt, ani markets: other cou Lake : principal be caugh ance. 'I'h but fome a fpecies that refer thicker, a each, and catching be taken wife man which m: refemblin a bait for half a cro Michizar

I'his lantic $\mathrm{Oc}$ as dinge the fnuth At the u ceives its dot, a Fr foil, is $\mathrm{Ai}$ fort is a imponfiub! careful p Thoug fupplicd erable on of the $w$ are carri bundanc 
$x$, that juf fall from dred feet. ke a white

borders of Algonkins, have been Láke Su. it, fome of In fide of it ty miles in ht as prop. rated from bay that ex. a thort por. eft it round,

pe juft de. se, the head e of Imall abuindance 5 banks. A $x$ places on all iflands, re covered ff copperas,

began, foon a) fome of irs.in Amer. ie It might as trade, at ind requires conveyed in e, to the $1 \mathrm{fl}$ f the Straits $m$ thence is them trans. gara, then it might bo conveyed without much more obftrustion to Quebec. The cheapnefs and eafe with which any quantity of it may be procuied, wiil make up for the length of way that is neceffary to tranfport it bèfore it reaches the fea coat, and enable the proprietors to fend it to foreign markets on as good terms as it can be exported from other countries.

Lake Superior abounds with a variety of the, the principal and beft are the trout and furgeon, which may. be caught, at almolt any feafon in the greateft abund. ance. The trouts in general weigh aboitt twelve opunds, but fome are caught that exceed fifty. Befidto thefe, a Species of white fith is taken in great quantities here, that refemble a thad in their foape, but they are rather thicker, and lefs bony; they weigh about four pounds each, and are of a delicious tafe: The beft way of catching thefe filh is with a net; but the trout might be taken at all times with the hook. There are. likewife many forts of fmaller fin in great plenty here, and which may be taken with eafe; among thefe is a fort refembling a herring, thrat are generally made ufe of as a hait for the trout . Very fmall crabs, -not larger than half a crown piece, are found botit in this and Lakk Michigan.

l'his Lako is as much affected by fortns as the Atlantic Ocean; the wives run as high, and are equaily as dingerous to hips. It difcharges its waters fro:n the fnuth eaft corner, through the straits of St. Marie. At the upper end of tiefe Sitraits finds a fort that se. ceives its nime from them, comnanded by Mons. Ca. dot, a French Canadian, who being nreprictor of the foil, is Gill permitted to leep polte (fion of it. . Near this fort is a very A rong rapid, againft which though it is impnffible for anoe; to afcend, yet when conduced by careful pilots, they might pafs duwn without danger.

Though Lake Superior, as 1 lave before obferved, is fupplicd by near forty rivers, rnany of which are confid. erable ones; yet it does not appear that one tenth part of the waters which are convejed into it by thefe rivers, are carried of at thi, evacuaticn fow fuch a fupera. bundance of waters can be difpofed of as it mun cern 
exinly be by fome means or other : without which the circumference of the lake would be continually enlarg. ing, I know not : that it does not empty itfelf, as the Mejiterranean fea is fuppofed to do, by an under cur. - rent, which perpeiually counteracts thit near the furface, is certain ; for the ttream which falls over the rock is nut more than five or fix feer in depth, and the whole of it paffes on through the Straits into the adjacent lake; nor is it probable that fo great a quantity can be abforb. ed by exhalations ; confequently they mult find a pafo lage though fome fubterranean cavities, deep, untutt. omable, and never to be explored.

The falls of St. Marie, do nut defcend perpendicular. Iy as thore of Niagara or St. Anthony do, but confif of a rapid which continues near three quarters of a mile, over which canoes well piloted might pafs.

At the bottom of thefe falls, nature has formed a mott

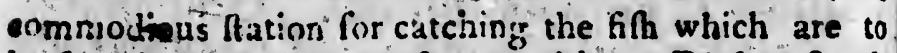
be found there in immenfe quantities. Perfons ftand. ing on the rorks that lie adjicent to it, may take with dipping nits, about the months of September and Octo. her, the white fith before mentioned; at that feafon, to. getler with feveral other fpecies, they crowd up to this fpot in fuch amaxing flioals, that enough may be taken to fipplo, when properly cured, thoufands of inhabit. anis throughout the year

I lie straits of St. Marie are about forty miles long, bearing fouth eaft, but varying much in their breadth. The current betweon the talls and Lake Huron is not to rapid as might be expected, nor do they prevent the nar. igation of thips of burden 25 far up as the Ifland of St. Jofeph.

It has been obferved by trayellers that the entrance into Lale Superior, from thefe straits, affords one of the mof pleafing profpeets in the world. 'The p'ace in whicn this might be viewed to the grecteft advantage, is juft at the opening of the lake, from whence may be feen. on the left, many beautiful little iflinds that exțend a confiderable way bclore you; and on the right, an a. greeable fucceffori of frnall poists of land, that prcjeet a little way iuto the water, and contribute, with the if.

ands, to termed) peltuous troubled

I.ake Araits of perior. of north grees of and its.ci

On thi ble for be more tha the name its, and is ready $\mathrm{me}$

Abuut is Sagana from the er i near illards, w noes and without $t$ acroors to woold im: about eig eighteen Nearly north we vermed. querited Europear imoufly a continual bay is ab and whil twenty fo the great There I could d b. thund? 
which the ly enlarg. if, as the ander cur. de furface, t,e rock is he whole cent lake; be abforb. ind a pafo $p$, untutt.

endicular. but confift of a mile,

ned a molt

ch are to cons fand. take with and Octo. féafon, to. up to this y be taken of inhabit.

niles long, ir breadth. on is not io int the nav. land of St.

ce cntrance one of the e p'ace in vantage, is nay be fcell. $t$ extend a ght, an a. hat project with the it. ands, to render this delightful bafon (as it might be termed) calm and fecure from the ravages of thofe tem. pettuous winds by which the adjoining lake is frequently troubled.

I,ake Huron, into which you now enter from the Atraits of St. Marie, is the next in magnitude to lake Superior. It lies between forty :wo and forty fix degrees, of north latitude, and feventy, nine and eighty five degrees of weft longitude. Its thape is nearly triangular, and its circumference about one thoufund miles.

On the north fide of it lies an ifland that is remarka. ble for being near an hundred miles in length, and no more than eight miles broad. This ifland is known by the name of Manataulin, which fignifies a place of fpirits, and is confidered by the Indians as facred as thofe al. ready mentioned in Lake Superior.

About the midale of the fouth weft fide of this lake, is Saganaum bay. The capes that feparate this bay. from the lake, are eighteen miles diftant from tach other; near the middle of the intermediate fpace ltand two iilards, which greatly terd to facilitate the paffage of canoes and fmall veffels, by affording them thelter, as without this fecurity it would not be prudent to venture acrofs fo wide a fea; and the coalting round the bay would make the royage long and tedious. I his bay is about eighty miles in length, and in general about eighteen or twenty miles broad.

Nearls half way between Saganaum Bay and the north weft corner of the Lake, lies another, which is wrmed 'l'burider Bay. The Indians, who have frequented thefe parts from time immemorial, and every European traveller that has paflëd through it, have unanimoully agreed to call it by this name, onjeccount of the continual thunder they have always obferved here. The bay is about niae miles broad, and the fame in length, and whilk I was paffung over it, which took me up near twenty four hours, it thundered and lightened during: the greateft past of the time to an excefise degree.

There appeared to be no vifible realon for this, that 1 could difcover, nor is the country in general fubject to thuader s the hills that food asound were not of a H. 2 
tema:kable height, neither did the external pates of them feem to be covered with any fulphurious fubflance. But as this phenomenon mult originate from fome nat. ural caule, I conjecture that the fhores of the bay, or the adjacent mountains, are either impregnated with an uncommon quantity of fulphurious matter, or contain fume metal or mineral apt to attr $x$ eी in a great degree, the eleatrical particles that are hourly borne over them by the palfant clouds. But the folution of this, and tliofe other philofophical remarks which cafually occur throughout thefe pages, I leave to the difcuftion of abler ireads.

The fith in Lake Huron are much the fame as thofe in Lake supericr. Some of the land on its banks is very fertile, and proper for cultivation, but in other parts it is fandy and barren. 'The promontory that feparates this lake frum Lake Michigan, is compofed of -a vat plain ${ }_{2}$ p pwards of a hundred miles long, but varying in its breadth, being from ten to fifteen miles broad. This trast, I have before obferved, is divided into alo mot an equal portion between the Ottowaw and Chip. eivay Indians. At the north eaft corner, this lake has a comnivication with Lake Michigan,by the Straits of Michillimackinac, already defcribed.

1 had like to have omitted a very extraordinary cir cunftancis, relaive to thefe ftraits. Ascording to nb. fervation, mace by the French, whillt they were in pof. feltion of the fort, although there was no diurnal finod or ebb to be perceived in thefe waters, yet, from an ex. act atterition to their ftate, a periodical alteration in them has been difciovered. It was obferved that they at ofe by gradual, but almolt imperceptible degrees till they had reached the height of about three feet. This was accomplifted in feven years and a half; and in the fame fpace they gently decreafed, till they had reached their former fituation ; fo that in fifteen years they had completed this inexplicable revolution.

At the time I was there; the truith of thefe obferva. tions could not be confirmed by the Englith,as they had been only a few years in poffeffinn of the fort but they all agreed that fome alteration in the limits of the Atraits 
ernal patts of rious fubltance. from fome nat. of the bay, or gnated with an tter, or contain a great degree, porne over them po of this, and cafually occur fcuftion of abler

- fame as thale on its banks is but in other omontory that is compofed of $s$ long, but vary. een miles broad. divided into alo waw and Chip. rner, this lake in,by the Straits

traordinary ciro cording to $\mathrm{nb}$. hey were in por. - diurnal finod yet, from an ex. teration in them thiat they asofe legrees till they feet. This was if ; and in the 1ey had reached years they had

thefe obferva. lith,as they had fort But they its of the Atraits was xppareht. All thele lakes are fo affeeted by winds, as foretimes to have the appearance of a tide, accor. ding as they happen to blow, but this is only tempo. raryi and partial:

A great humber of the Chipeway Indianslive fcattered around this lake, particularly near Siggandum Bay. On its banks are found an amazing quantity of fand cher. ries, and in the adjacent country nearly the fause truit as thofe that grow about the other lakes.

From the falls of St: Marie I leafurly proceeded back to Michillimachinac, and arrived there the beginning of November 1767, having been fourteen months $\mathrm{C}$. this extenfive tour, travelled near four thoufand miles, and vifited twelvenations of Indians lying to the weft . n rorth of this place 7 he winter fetting in foon afte

at. rival, I was obliged to tarry there till June following, the navigation over Lake Huron for large veffeis not be. ing open, on account of the ice, till that time Meeting here with fociable company, I paffed thefe monih very agreeably, and without finding the hours tedions.

One of $\mathrm{my}$ chief amufements was that of filning fot trouts. 'Though the Straits were covered with ice,' we found means to make holes through it,and letting down frong lines of fifteen y arcis in length, to which were fix. ed three or fotr-hooks baited with the fmall filh before defcribed, we freequently caught two at 2 time of forty pounds weight each; but the common fize is from ten to twenty pounds. Thefe are molt delicious ford. The method of preferving them during the three months the winter generally lafts, is by hanging them up in the air and in one night they will be frozen fo hard, that they will keep as well as if they were cured with falt.'

I have only pointed o:l in the plan of $m y$ travels the circuit I made from leaving Michillimackinac till I ar: rived again at the fort. "Thofe countries that lie nearer the colonies have been fo often and fo minutely deferib. ed, that any further account of them would be ufelefs. I thall therefore only give my readers in the remainider. of my journal, as I at tirlt propofed, a deficription of the other great lakes of Canada, many of which I have 


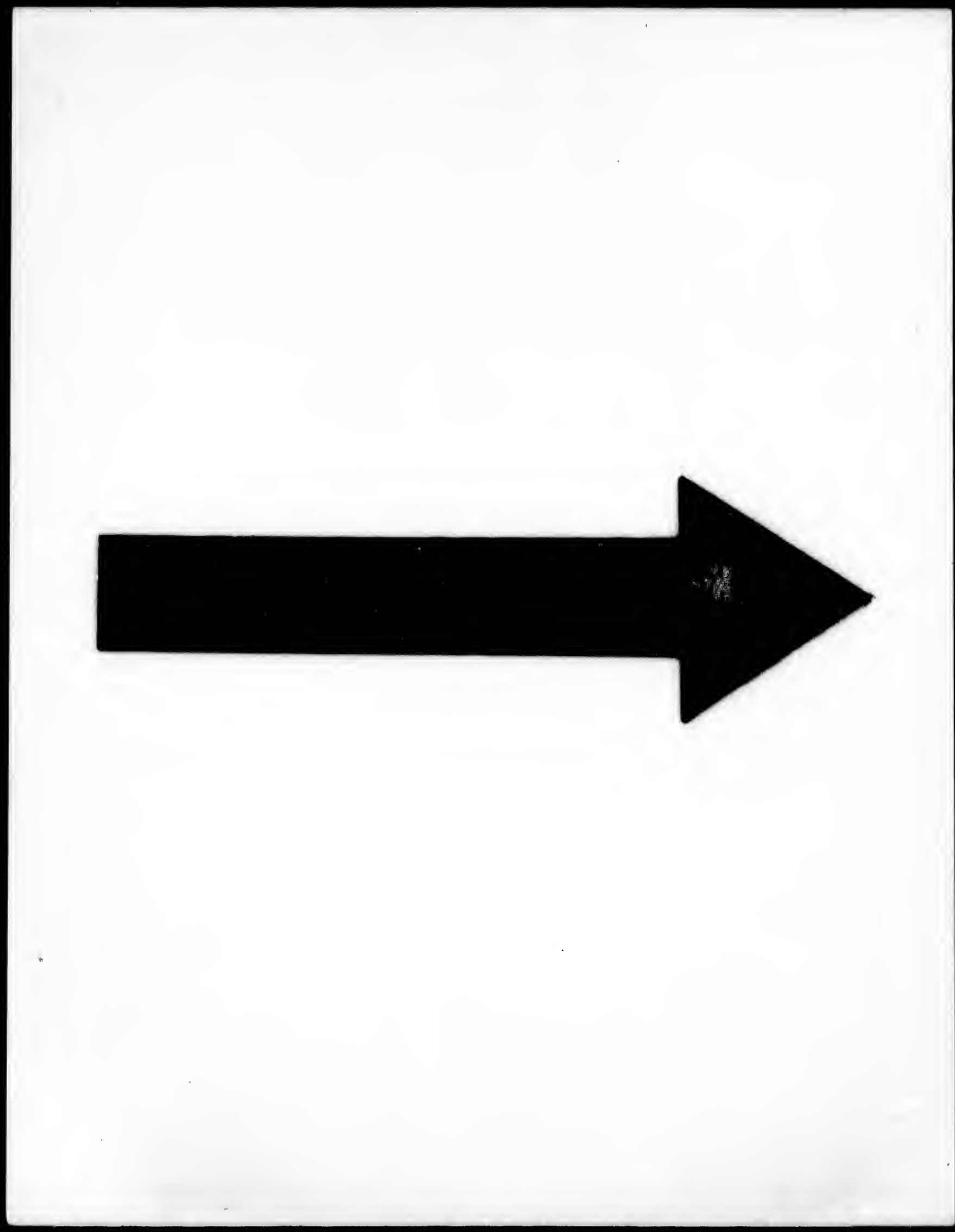




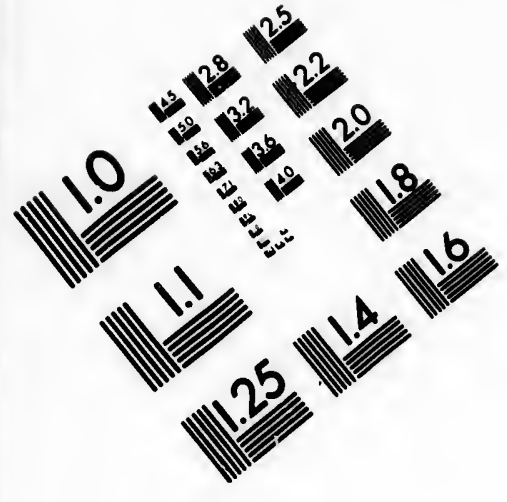

IMAGE EVALUATION

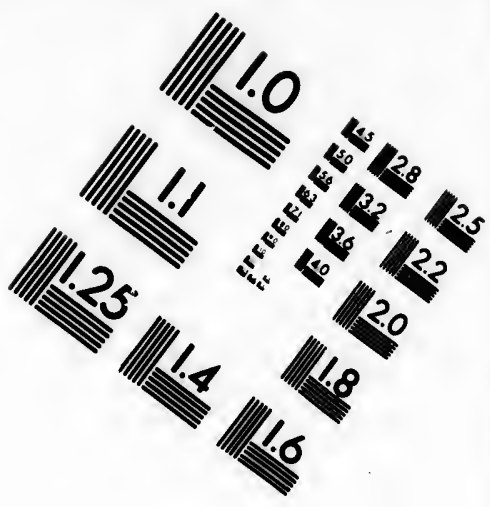

TEST TARGET (MT-3)
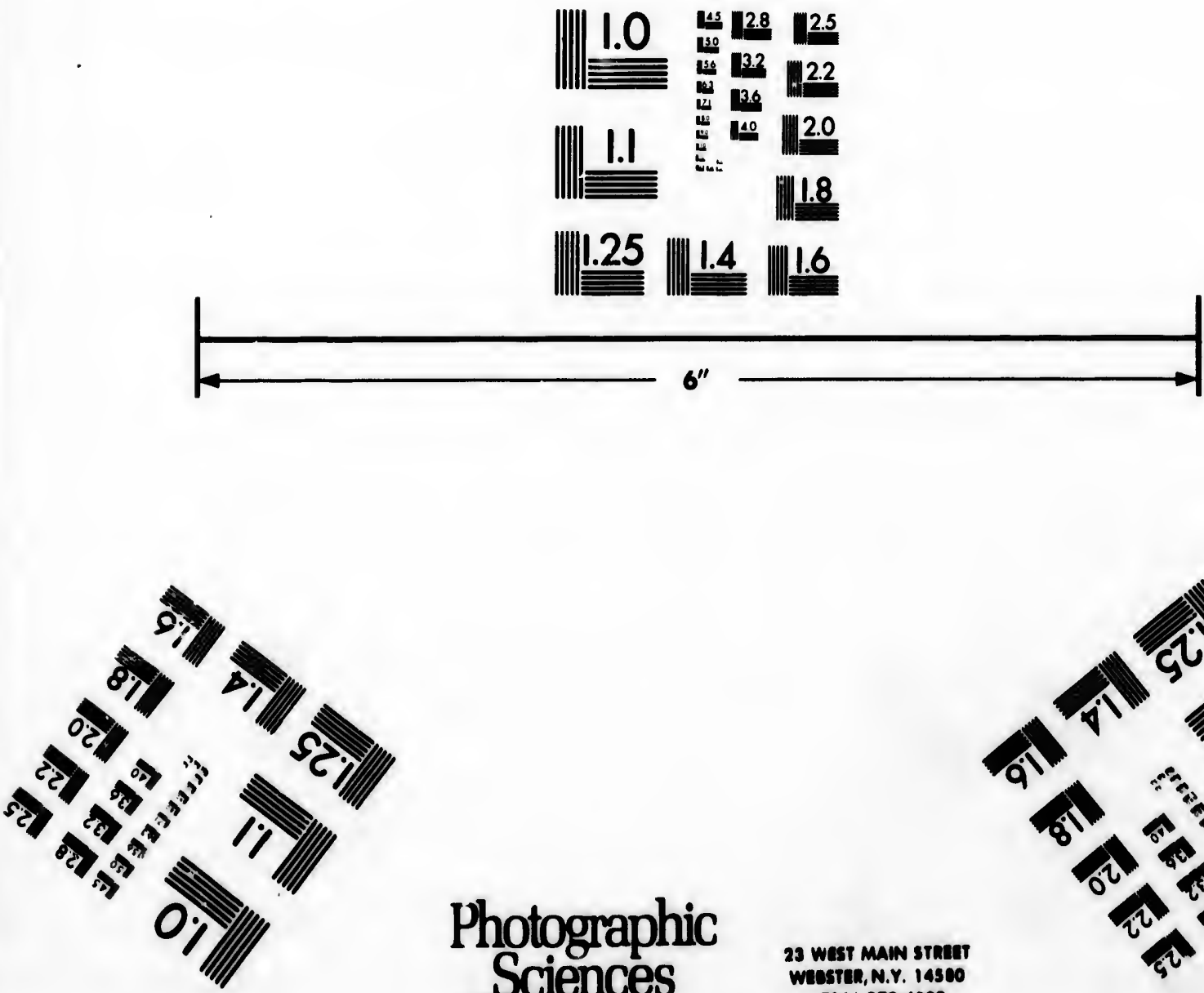

Photographic Sciences

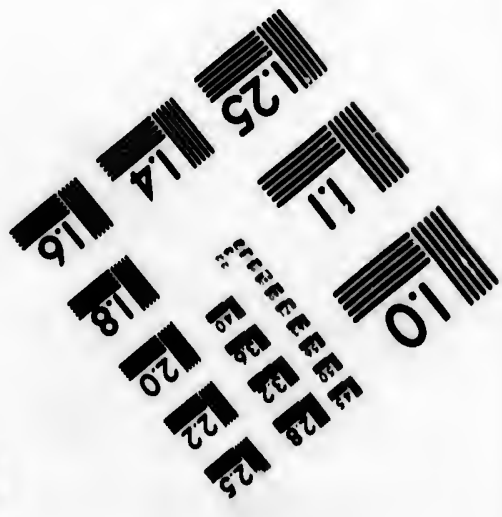
Corporation 
navigated over, and relate at the fame time a fev partic. ular incictents that I trult will not be found inapplicable. or uninterefting.

In June 1768 I left Michillimackinac, and returned in the Gladvira Sohooner, a veffel of about cighty tons burthen, over Lake Huron to . Lake St. Claire, where we left the thip, and proceeded in boats to Detroit. This lake is boout ninety miles in circumference, and by. the way of Huron River, which runs from the fouth corner of Lake Huron, reteives the water's of the three great lakes, Superjor, Michigan, and Huron. Its form is rather roprad, and in fome places it is deep enongh for. the riavigation of large veffels, but towards the middle of it there is a bar of fand, which prevents thofe that are tuaded from pafling over it. Such as are in ballaft only may find water to carry them quite through ; the cargoes, bowever, of fuch as are freighted mul be taken out, and after being tranfported acrofs the bar in boats re. fhipped again.

The river that runs from Lake St. Claire to Lake E. ric (or rather Strait, for thus it might be termed from its name) is called Detroit, which is in French, the Strait. It runs noparly fouth, has a gentle current, and depth of water fufficient for thips of confiderable bus. then. The town of Detroit is fituated on the weftein banks of this tiver, about nine milos below 'Lake Sto Claire.

Almuft oppofite on the eaftern thore, is the village of the ancient Hurons: a tribe of Indians which have been treated of by fo many, writers, that adhering to the reftrictions I have laid myfelf under of only. defcribing places and people little known, or incidents that have paffed unnoticed by others, I thall omit giving a defcrip. tion of them. A miftionary of the order of Carthu. fan Friars, by permiffion of the bilhop of Canada, refictes. amony them.

The banks of the River Detroit, both above and be. low thefe towns, are covered with fettlemsnts that ex. tend more than twenty miles; the country being excee. dingly fruitful, and proper for cultivation of wheat, In. dian corn, onts, and peas, Is has alio many Ipots of

fire palto

French th ter the are more it is bad

the to dred hou have a ra with 2 fp fide lies which is The forti ade, mad and lined Imall ball cannion of defence a with artil

l'he ga drẹd men chief $\mathrm{ma}$ Turnhu:! icans, wa This gen bnth by $t$ of his con of thins $\mathrm{p}$ for the ci

In tive this town of the col collested ly intellig of that already 1 not to $\mathrm{fa}$ withlarintefted in before ex molt ever the circu 


\section{CARVER'S TRAVELS.}

particplicable.

returned hty tons , where Detroit. and by theorner. ae great form is ough for middle ofe that n ballatt gh : the be taken in boats

Lake E. ed froin. ich, the ent, and. ble bur. weftein. ake St.

illage of. ch have. ng to the efcribing lat have. defcrip. Carthu. lajrefidus.

and be. ithat ex. is excee. hrat, In. fpots of fire palturage; but as the inhabitants, who are chiefly French that fubmitted to the Englifh government, after the conqueft of thefe parts by General A mberf, are more attentive to the Indian trade than to farming, it is badly cultivated.

The town of Petroit contains upwards of one hundred houfes. The fireets are fomewhat regulir, and have a range of very convenient and hanufome barracks. with 2 fpacious parade at the fouth end. On the weft fide lies the king's garden, belonging to the goverrior, which is very weil laid out, and kept in good order. The fortifications of the town confift of a ftrong ftack. ade, made of $z$ onnd piles, fixed firmly in the gtound; and lined with palifades. Thefe are defended by fome Imall baltions, on which are mounted a few indifferent cannon of an inconfiderable fize, juit fufficient for its defence againit the Indians, or an enemy not provided with artiliery

'The garrifon in time of peace, ennits of two hun dred men, commanded by a tietd officer, who aets as. chief magittrate under the governor of Canada. $\mathrm{Mr}$. Turnhu:l, captain of the 6th regiment; or Royal A mericans, was commandant when 1 happened to be there: This zentieman was defervedly efteemed and refpected; brich by the inhabitants and traders, tor the propriety of his conduct; and I am happy to have an opportunity of thas publicly making my acknowledyements to him for the civilitie. I received from him during my Atay.

In the year 1762, in the month of July, it rained on this lown and the parts idjacent,' a fulphure ous water of the color and confiftence of ink ; fome of which being cillecred into bottles, and wrote with, appeared perfeet. ty iritelligible on the paper and anfwered every purpofe of that ufeful liquid soon after, the Indian ware already tpoken of, broke out in theie parts. I mean not to fay that this incident was ominons of them, not. withlaning it is well known that innumerable well attefted infances of extraordinary phensmena happening before extraorilinary events, have been recorded in al. molt every age by hillorians of veracity ; I only - relate the circumitance as afad, of which if was informed by 
many perfons of undoubted probity, and leave my read. ors, as I have hitherto done, to draw their own conclu. Gins from it.

Pantiac, under whom the party that farprifed Fort Michillimackinac, as related in the former part of this work, akted, was an enterprifing chief or head-warrior of the Miamies. During the late war between the Eng. lith and the French, he had been a Aeady friend to the latter, and continued his inveteracy to the former, even after peace had been concluded between thefe two nations. Unwilling to put an ead to the depredations. he had been fo long angaged in, he colleated an army of corfederate Indians, confliting of the nations before enumerated, with an intention to renew the war. How. exer,inftead of openly attacking the Englith fettlements, he laid a fcheme for taking by furprife thofe forts on the extremities which they had lately gained poffeftion of.

How irell the patty be detached to take Fort Michil. limackinac fucceded, the reader already knows. 'Io get into his binds Detroit, a place of. greater confequence,and much better guarded, required greater refo. lintion, and more confumate art. He of courfe wok the managentent of this expedition on himfelf, and drew near it with the principal body of his troops. He was. howozer, prevented from carrying his defign into execu. tion, by an apparently trivial and unforefeen circum. fince. On' fuch does the fate of mighty limpires fre. quently depend !

- The town of Deiroit, when Pontiac formed his plan, was garritoned by about three hupdred roen command. et by Major Gladwy "gallant offiçer. As at that time every appearance. ar was at an end, and the In. dians feemed to be on friendly footing. Pomiac approach. ed the Fort, without excitiug any furpicions in the breal of the governor or the inhabitants. He encamped at a litele diftancefrom it, and fent to let thecommandant know thet he was come to trade; and being defirous of brightoing the chain of peace between the Englifh and his nation, defired that he and his chiefs might be -ad. mitted to hold a council with him. The governor Aill anfufpicious, and nos in the leaf doubting the fincerity

of the fixed on Thee been em of India home. ding the take the bitinfelf. thofe the went to the there viels on $v$ beri, and however

Some and engt Not bein the wom prefence' Joitering were 'thu he' had is tation. if defs:tow: remainde upon it 8 cilf to te reluetant the form id; that 1

His cu difclofin: in her bo prounife lhould ne to bouben formed i dians thé to murde endiohat 
ny read. conclu.

ed Fort of this -warrior he Eng. to the ex, even sefe two iedations.

in army 18. before How. tlements, ts on the ion of.

t Michilws. 'To er confe. ater sefo. cook the nd drew He was. nto execu. circumpires fre.

his plan, ommand. Is at that d the In. approach. the breall inped at 2 dantknow efirous of hglith and it be-ad. rernor fill . fincerity of the Indians, granted their general's requen, and fixed on the next morning for their reception

The evening of that day, an I Itian woman who had been émployed by major Glaidwyn, to make him a pait of Indian thoes, out of curious elk fkin, brnught them home. The major was fo pleased with them that inten. ding thefe as a prefent for a friend, he ordered her to take the remainder back, and make it into others for himfelf. He then directed his fervant to pay her for thofe the had done, and difmifled her. The woman went to the door that led to the Atreet but no further; the there loitered about as if the had not finilhed the buffdefs on which the came. A fervant at length obferved bij, and atked ber why the ftaid there ; the gave him, bowerer, ng anfurer.

Some thott time after, the governor himfelf faw her, and enquilred of his fervant what occafioned her ftaj. Not being able to get a fatiffuetory anfwer, he ordered the woman to be called in. When the came into his prefence'he defired to know what was the reafon of her loitering about, and not haftning home before the gate were thut, that, the might complete in due time the wort he had given her to dr. She told him after mueh hefitation. that as be had always behaved with great good. aefs towardsher, the was unwilling to take wway the remainder of the fkin, becaufe he put fo great a value upon it $;$ and yet had not beets uble to prevail upon hero aff to tell him fo. He then afked her, why ifne was more reluetant to do fo now; thitri the had been when 'the made the former pair. With increafed reluetance five anfwerad; that the never : thould be able to bring them baek.

His curiolity being now exoited, the infifted on hit difclofing to him the fecret that feemed to be Arugling in her bofom for utterance. At lalt on peckiving'a proinife that the intelligence the was'about to give him thoukd not curn ton her prejudice, and that if it appeared to be beneficial, the thould be rowarded tor 'it;' the in. formed bim, that at the council to be held with the In. dians the following day, Pontiac and his chiefs intended 10 murder him s and efter baving maffacted the garrifon adrinhabitante, to plunder the cown That for thie 
purpole all the chiefs who were to be admitted into the council-room, had cut their guas thort, fo that the could conceal them under their blankets; with which at a I gnal given by their general, on delivering the belt, they were all to rife up, and inftantly to fire on him and his attendants. Having effected this, they were immediately to rufh into the town, whe:e they would find them. telves fapported by a greal number of their warriors, that were to cume into it during the fitting of the coun. cil, under pretence of rrading, tut privately asmed in the fume manner. Having gained from the woman ev. ery necefiary particular velative to the plot and al.o of the menns by which the acquired a knowledge of them, he difruffed her with injunctions of fecrecy, and 2 promile of tulfilling on his part with punctuality, the ed gagements he had enteted into.

1. The intelligence the governor had juf received, gave him great uneatinefs and he inumediately confulted the officer who was next to him in command, on the fubject. But that gentleman confidering the information as a Aory invented for forre artful purpofe,advifed him to pay no attention to it $\mathrm{l}$ his conclufion, however, bad happily no neight with him He thought it pru. dent to conclude it to be, true, till he was convinced that it was not fo; and thet efore, withont revealing his fufo picions so any other perfon, he took every needful precan. tion that the time would admit of. He walked round the fort during the whole night, and faw himfelf that evary fintinel was on duty, and evary veapon of defence in proper order.

As be traverfed the samparts, which las neareft to the Indien camp, he heard them in high feftivity, and, lit ice imaginiag that their plot was difcoveredaprobably p'eas. ing themfelves with the anticipution of their tuccefs. As tionas the morning diawned, he ordered all the garrifon under orme; and then imparting his appreheations to u fir of dle principal coficers, gave fuch ditedions as 14 thought neceflury.

- At tho fame time be fens round to all the traders co inform them, that as it was expeded a great number af Indian would entec the town that day, who

\section{(1) \\ (1) \\ (1)}

(2010

\section{(}

\section{.}

\section{,}


into the ae) could ich at a belt, they $n$ and his immediind them. warriors, the coun. armed in roman ev. nd alfo of of them, cy, and a ity, the eno

ived, gave confulited d, on the formation. Ivifed him however, ght it pru. convinced ing his fuf. ul precav. ked round lif that er. defence in

Ireft to the and, litice ably p'eass. is fucecfo. II the gar. rehentions redions as

c. traders to number day, who

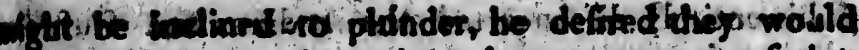
Give their ai mo ready, and inpel every attempt of thist

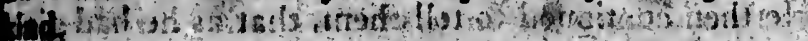

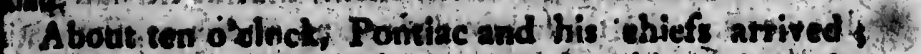

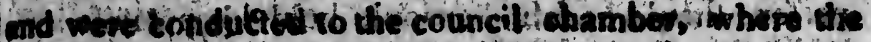

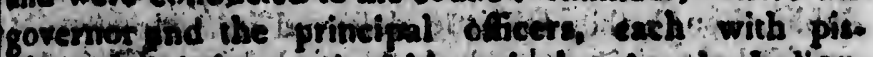

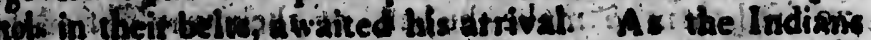

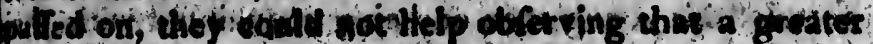

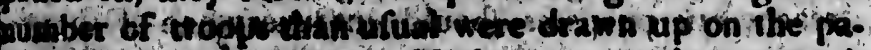
ade of marching about. No fooner were they onutred,

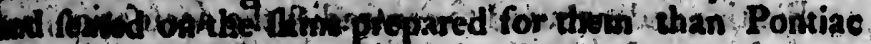

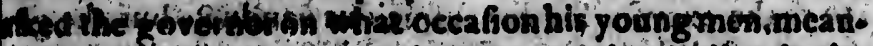

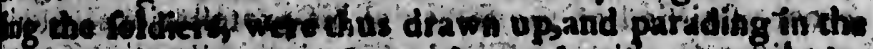

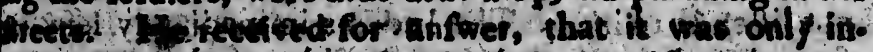

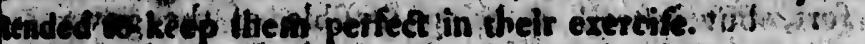

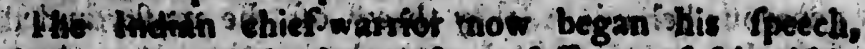

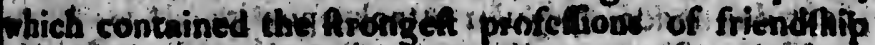

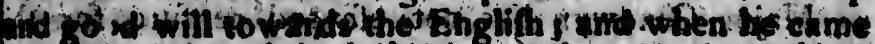

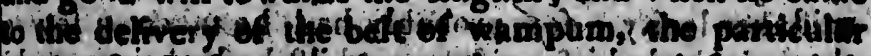

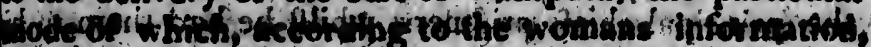

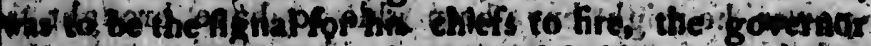

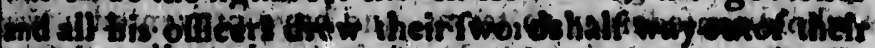

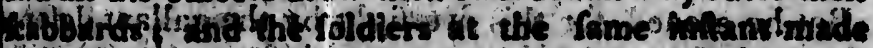

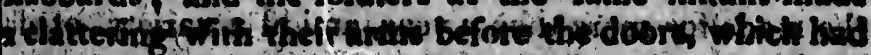

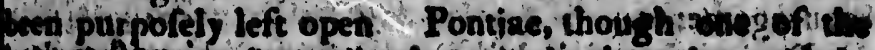

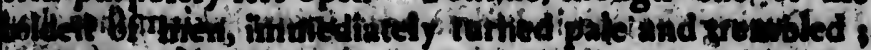

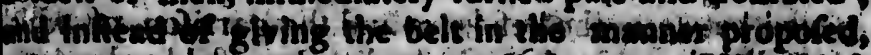

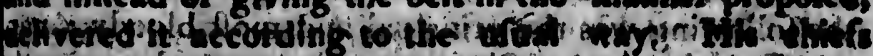

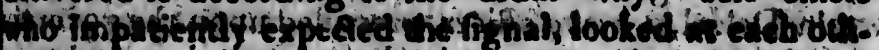

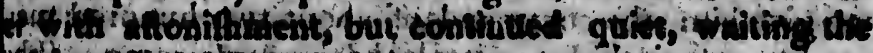

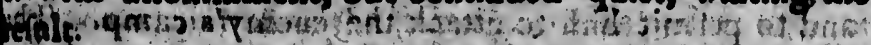

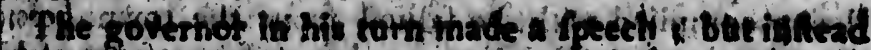

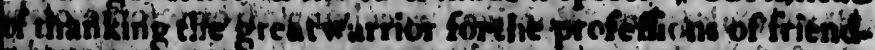

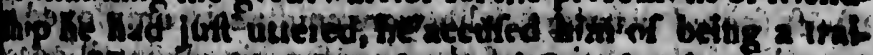

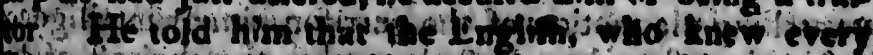

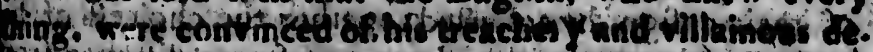

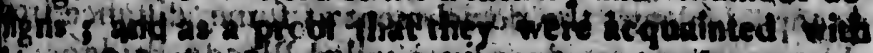

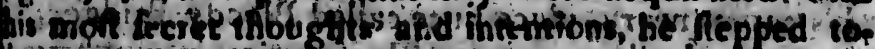

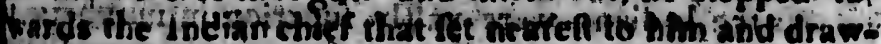

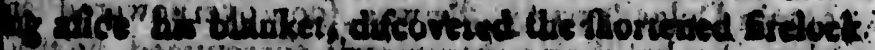

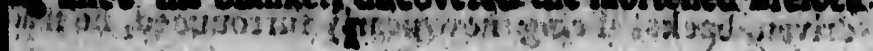




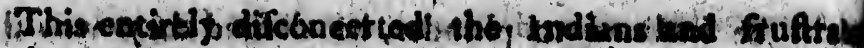

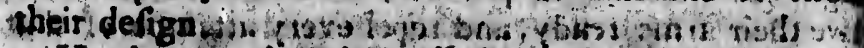

He then costinuld 10 tell them, that as he had giv

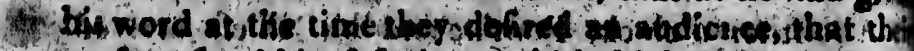

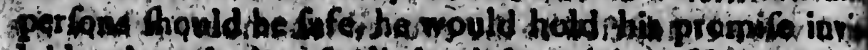

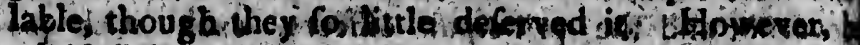

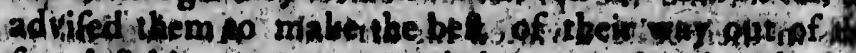

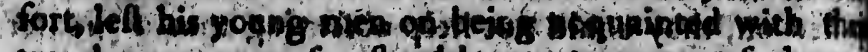

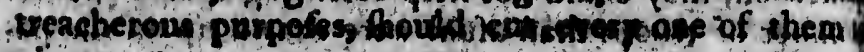

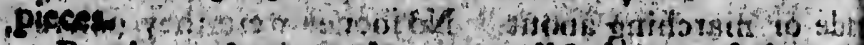

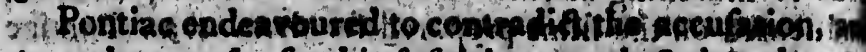

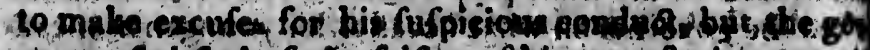

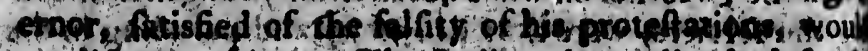

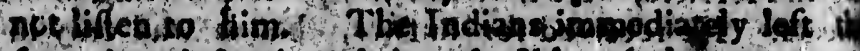

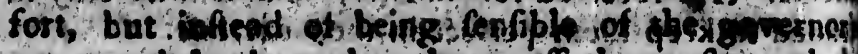

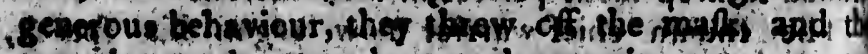

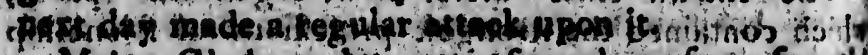

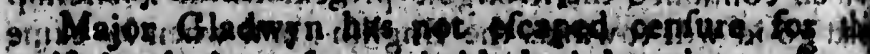

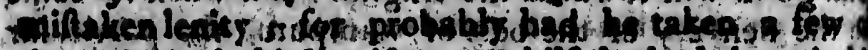
1)

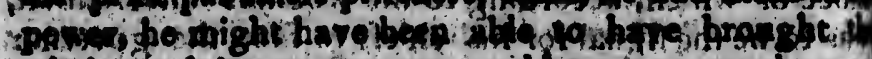

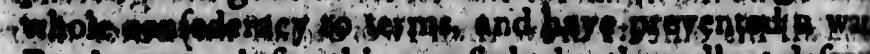

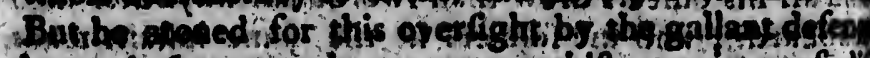

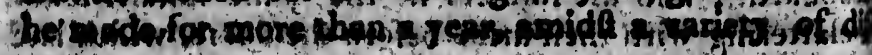

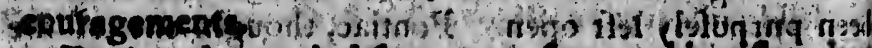

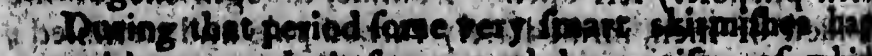

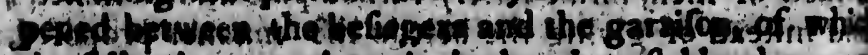

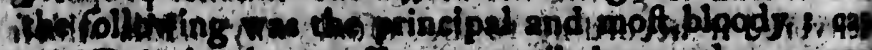

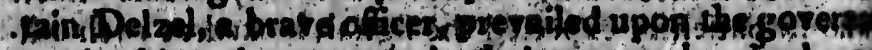

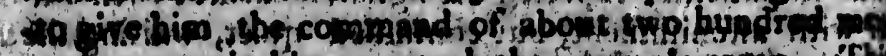
and to permit bim to atrect the etroting's camp. $j$ if

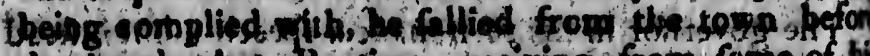

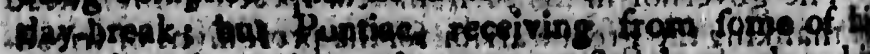

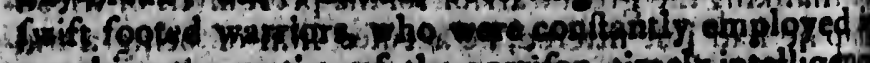

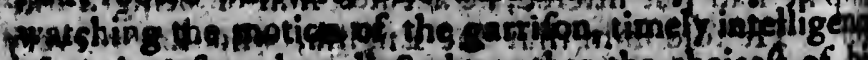

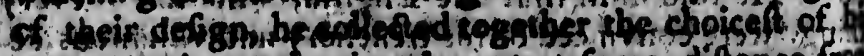

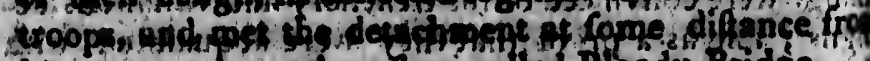

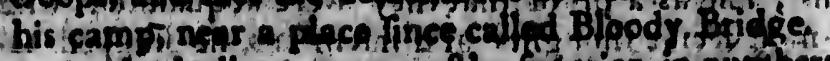

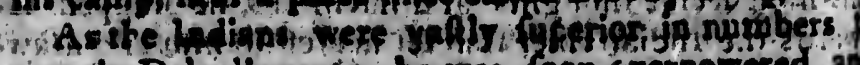

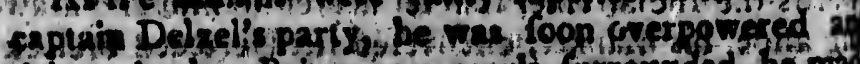
driven bact. Reipg now neay f urrouodad be wat

Digstols

ifotrola

aivider ostoney kintily $a^{2}, 2,2$ antrerd: Anatinto Sithicice theteon betield ou (t) Afvertiti Siscic cl inktwits? mitivitis Linclitin could not arrived bb venctin ins? asuld reac amuif Theindia reat have Atrieng rable nus binining the lientet 4. and w Kould nol is alternat det room the point : rens, who Whis frie seiving th (iides of an far tron dincel and arriv pown.

This $\mathrm{Se}$ 
fitultar rists le had giv" wishat theil omicétiprie. Iowerent restutiof $x$ en dichich of thean sits 10 sht uffuion, int bytighegen (iomenouly ly lef risinmener. Alsi and th troos as

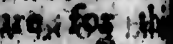
exigh fith theonjint hrowente in

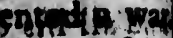
Haved dee tots di aptisntast turing ragl inutionitat boxpfrinthic modrisiag: thesegrextion

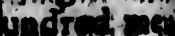
amporifin sozes shefor soping of th Qmpligned forfligen picest of $h^{2}$ iflance ro action Brida. ny.ipgers oninged an bed be wate

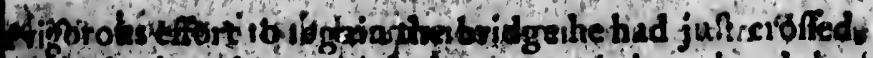

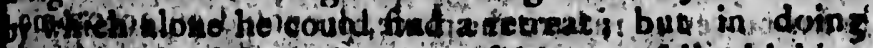

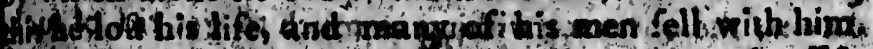

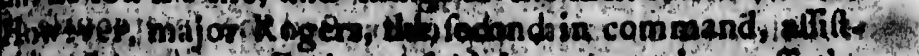

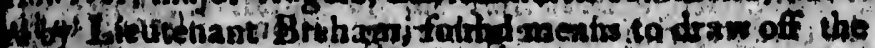

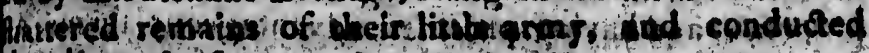

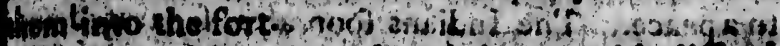

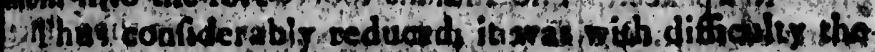

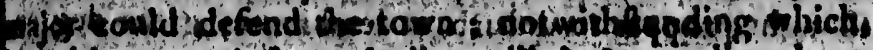

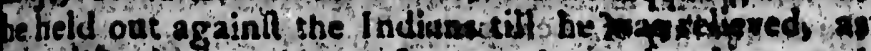

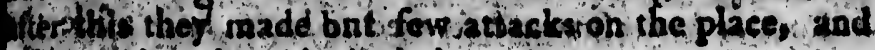

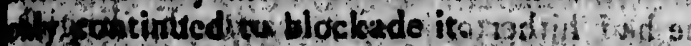

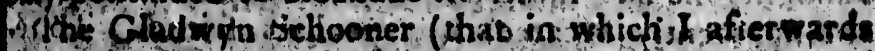

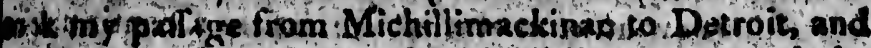

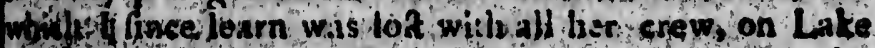

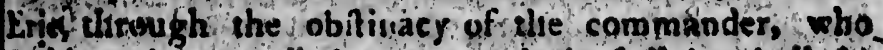
could not be prexailed upon to take in fuftisieni ballaft) urivad about this tine never tize town, willi a reinforce. aeno, thid trecefory fupplies. But betore the veffel cotid reach the place of its detination, it th moft vig ornufly atticked by a detachment from Pontiac's army. The Indiansfurrnunded it in their canoes and made great havoc anong the crew.

Fitjength the ciptain of the fchnoner, with a confls. stable number of his men being killed, and the favages beginuing to climb up the lides from every, quarter, the lieuteane (Mr. Jicobs, who ufterwards command. di and was loft in lif being determined that the ftory Arould not fall into the enemy's hands, and feing no othginlernative, ordered the gunner to set fire to the pow der roorip and blow the thip up. I bis order was on the point of being-executed, when a chief of the Hurong, who underftood the Englith language, gate out Whis frieodo the intention of the commander. On so. roiving this intelligence, the Indians hurried down the Gides of the thip with the greateft precipitation, and got a far trom it as pofible, whill the cocomander imme. diacely took the advantage of their conflemation. and arrived wichout any further ubfrustion at th nown.

This felonable fupply gave the garrifon freh spirity 


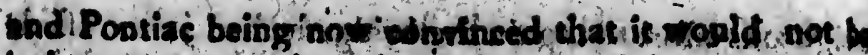

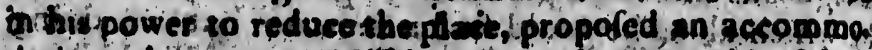
dation the govemot th in onumach to get tid of f 4 h

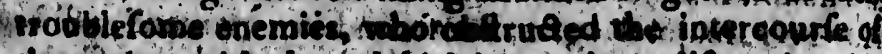

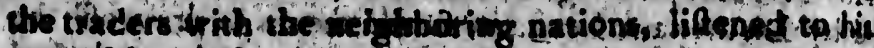

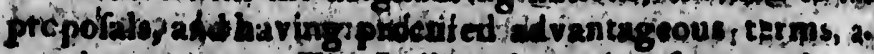
greed to apeace. The Indians foon utow feparatudand

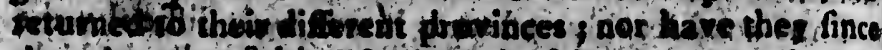

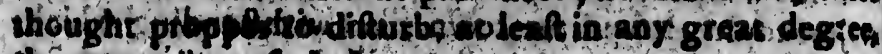

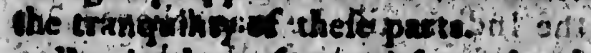

Pontiactheacefondent fetried to hbve lajd afite the animolity he had hithertolborne to atd the dingtilf

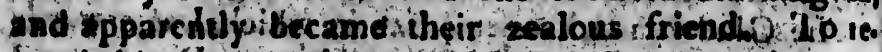

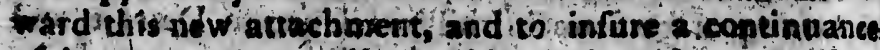
of it govefnment allowed him a bandfoque penfipu. Dur bis relltefs and tátrigueing fpirit would not fuffer him to be grateful for this allowance, and his conduct at leigth grew fufpicious s fo that going in the year 1 67 , to fiold a couricil in the country of the Hingois, a faithful Indian, who was either commifioned by one of the Englif governors, or infligated by the love he bofe the Englith nution,attended him as a fpy i and being convin: ced from the fpech Pontice made in the counitit at he Aill retained his former prejudices againlt thofe for whom he now profeffed a friendibip, be plunged his knife into bis heart, as foon as he had done fpeaking, and hid him dead on the fpot. But to return from this digrellion.

Lake Erie receives the waters by which it is. fupplied from the three great lakes, through the tiraits of Detroith that le at its north weft comer I bis like is fituated betreon forty ore and forty three degiees of north lat itude, and between fevent teight and eighty three degrees of wett longitude. Itis near three hundred miles long ti om eaf to vief, and about forty in its broadefl part: and a re markablelong narrov pointlies on its north fide, that pro jeets for feveral miles into the lake towards the fouth eatt.

There are feverul iflands near the weft end of it $f 0$ in. felled with rattefnaker, that it is very dangerous to Isud on them Ic is impotitble that any place can pro. duce a greater kind of all thefe inptiles than this does, particularly of the tater fólke. the lake is covered

cear the the leave as $10 \mathrm{cov}$ ench of $t$ ter fnake injriads. 1 The $n$ felt this peckled an) thine its fpots, brighter is mouth ad to be breath of 8 decline being no its banefi

The fil nofit of $t$ foots thai of $\mathrm{now}$ fixe of lie the linds

The in ous thin lands the maters in sether and boat them to

This 1 into the is about $t$ into thak its coller willes fur roind intrive of As th: Sirngu 
Id not in accompor ift of fuch reourfe of ind to his is tarms, as recisid, and the fince as degten thist

it aride the - idingtild thit tio 10 . mpeinuance: a penfipu. not ? fuffet - conduct 1) alle year Lllinois, a rone of the te bote the ing convin. wilitirat he for whom knife into id thid him digreflion. is. fupplied of Detroit, is fituated north lat. ireedegreet slongtion and a re Le, that pro fouth eatt. of it fo in. ngerous to - can pro. this does, is covered near the banks of the iflands with the large pond lilly; the leares which lie on the furface of the wrater fo thick, a no cover it entirely for many actes together 3 and on each of thele lay, when I palled orer it, wreaths of was ter fnakes, bafking in the fuo, which amounted to myriads.

1 The moft remarkeble of the different fpecies th $t$ infet this lake is the bifing frake, which is of the fmall fpeckled kind and is about eight incher long. When any thing approaches, it flattens itfelf in a moment, an $\rfloor$ its fpots, which are of rarions djes, become vifibly brighter through rage $;$ at the fame time it blows from is mouth, with great force, a fabtile wind, that is reportad to be of a naufeous fmell, and if drawn in vith the breath of the unwaty traveller, will infallibly bring on a decline, that in a faw months muf prote mortal there being no remedy yet difcoviced which can counteral its baneful influence.

The flones and pebbles on the fhores of this lake are moft of them tinged, in a greater of lefs clegree, with fots that refemble brafs in their color, but which are of 2 more filphoreous nature. Small pieces, about thefize of hazleriuts, of the fame kinds of ore, are found on the iands that lie on its banks, and under the water.

The na vigation of this lake is efteemed more danger. ous than any of the others on account of many high lands that lie on the borders of it and project into the water, in a perpendicular divedipa for many miles to. bether i fo that whenever fudden forms arife, canoes ind boats are frequently loo, as there is no place for them to find a fhelter.

This like discharges its waters at the north eaft end, into the river Niagak, which runs north and fouth, and Is about thirty fix miles it leng th, from whence it falle into take Ontario. At the entrance of this rivor, on its eqlera Phore, lies fort Niagara, and about eighteen wiles further up, thofe remarkable falls which are of coined one of the molt extreordinary productions of niture at prefene knowa.

As thefo have beep vilited by fo man travellers and Sifrequentls defcribed, I thall omit, giving a partic 18 
lar defcription of them, and oals obferve, that the ters by which they are fupplied, atter tutting their rill inear two thoufand willes, to the norch wel, and paffing through the lakes Superior, Michigan, Huron, and Elie, during which they have been receiviag conftant accu. mulations, at length rufh down a flupenduous precipice of one hundred and forty feet perpendicular, and in a ftrong thpid, that extends to the diftance of eight or nine - miles below, fall nearly as much more ? this river food after ecaptie itfelf into Lake Ontario.

The noite of thefe falls may be heard an amazing way. I could plainly dillinguifs them in a calm morn. ing more than iventy miles Others have faid that at particolar times, and when the vind fits fair, the found of them reaches ffficen leagues.

The lind about the falls is excedingly hilly and un. even, but the greatelt $p$ in of that on the Niggara tivet is very good, efpecially for grafs and pafturage.

Fort Niugara acids neatly at the entrance of the wet crid of lake Cnitario, and on the eal part of the fraits of Niagara. It was talien ti om the Tirench in the jear 1759, by the foi ces unuer the command of fir William Johnfor, and at prefext io defended by $a$ confiderable garrifon.

* Late Oritario is the next and leaf of the five great Whet of Canada. It fituation is between fort thice and fortv five degreas of laitude, and between Ceventy fix and feventy nino degrees of waft longitude The form of te is nearly atolits greatef length being from north eaf to fouth wet, and in circumference, abuut fix bundred miles. Near the fonth eaf part it receives the water of the Ofwego River, and on the north eaf - dícharges itfelf into the kiver Cataraquit Not far from the place where it iffues, forthroutenac formerly Aood, which was twken from the French during the lat Yas, in the year 1758 , by a fuall army of Provincialo ander col. Bradftreet:

At the entrance of Ofrego River fands a fort of the came name gartifoned onlt at prefent by an inconfid. - trable party. This fort ras tiken in tle year 1766 , by the Frevels when a great part of tha garrifon which

confite

were to

In 1 a

which:

meighin

fort cal

very ling and the

Onit

eafi of: ges, whe on whic cornitery. and eatt may ma

ithe $C$ Ofwego, its rife n fo adjace Huicesis mothth ol long fror country.

Lake which tie length, $n$ wen. It on all the

Lake I St Sucr: tioned Ial nocth ens country a lies the da When lnown b laker, 8 at parts, we rete callo of the fiv cda I In 
the that their rile ad paffing and Eric, tant accu. i precipice and in a hit or nine iver $f_{009}$

lamazing alm morn. id that at the lound

and ungara tive? je.

of the wet the Atraits n tlie jear William nfiderable

Gre great orts three a ferrenty de. The ing from ce, about trecuives horth eaft Not far formerly Ethe lat orincialo (t)

ort of the inconfid. 1766, by sin which watted of the Jate Shirley's and Pepperel's regiments, were maffacreed it cold blood by the lavages.

In lake Ontario are taken many forts of tifh. among which is the Ofwego bals, of an excellent flavor, and weighing about three or four pounds. There is alfo a fort called the cat head or pout, which are in generat very linge, forme of them weighing eight or ten pounds and they are efleemed a rare dith whep properly drefled.

On the north wet part of this lake, and to the fourh eafi of Jike Huron, is a tribe of Indians called Mifitiauges, whole town is denominated loronto, from the lake on which it lies s but they are not very numerons. The cointry about lake Untaxio efpecially the more north and eattern parts, is compofed of good land, and in time may nake very flourilhing fettlements

The Oneida lake fituated near the head of the river Olwego, receives the waters of Wood creek, which takes. its rife not far from the Mohawl's river. Thefe two lie fo adjacent to each otber, that a junction is effected br Huices at furt Stanwix, about twelve miles from the mouth of the former. lhis lake is ubout thirty miles long from eaft to wet, and near fifteen broad, Tho coutry eround it belongs to the Oneida Indians.

Lake Champlain, the next in fize to lake Ontario, and Whish lies nearly eat from it is about eight toiles in length, north and fouth, and in its broaden part four. wen It is well ftored with fint, and the lands that lic on all the borders of it, and about its rivers, tory good. Lake George, formexly called by the French, dake St Sacrament, lies to the foush welt of the laft men. tioned lake, and is about thirty five miles long from north eaft to fouth welt but of no great breadth I'ho country around it is rery gountainouy but in the val. Lies the land is tolerably good

When thefe tyolakes were fin difcovered, they were knowa bf no other name than that of the Iroquois lakes 3 and I believe in the Grit plans taked of thofo parts, were $f 0$ denominated. The Indians affo that were ealled the Iroquois iare fince known by the name of the five Mohawt nations, and the Moliawks of Can. ida In the late war, the former, which confin of the 
Onondagoes, the Oneidas, the Senecas, the Tufcarories, and Iroonducks; fought on the fide of the Englifh : the latter which are called the Cohnawaghas, and St. Francis Indians, joined the French.

A valt trae of land that lies between the two laft mentioned lakes and lake Ontario, was granted in the jear 1629, by the Plymouth cumpany, under a patent they had received by king Jamés I. to fir Ferdinando Gorges, and to captain John Mafon, the head of that family, afterwards diftinguithed from others of the fame name, by the Mafons of Connecticut. The countries fpecified is this grant are faid to begin ten miles from the heads of the rivers that run from the ealt and fouth into lake George and lake Champlain; and continuing from thefe in 2 diree line reftward, extend to the mid. dle of lake Ontario; from thence, being bounded, by the Cataraqui, oi river of the Iroquois, they take their courfe to Montreal, as far as fort Surrell, which lies at the junction of this river with the Richlieu and from that point are enclofed by the laft mentioned river till it returns back to the two lakes.

This immenfe fpace was granted by the name of the Province of Laconia, it the aforefaid gentlemen, on fpecified conditions and under certain penalties ; but none of thefe amounted in cafe of omiffion in the fulfil. ment of any part of thent, to forfeiture, a fne only could be exalted.

On account of the continual wars to which thele part have been fubject. from their fituation between the fettements of the Englilh, the French, and the Indians, this grant has been fuffered to lie dormant by the real proprietors. Notwithltanding which, foveral towns have been fettled fince the late war, on the borders of lake Champlain, and grants made to different people by the governor of $\mathrm{New}$ York, of part of there territories, which are now hecome annezed to that province.'

There are a great number of lakes on the north of Canada, between I abiador, lake' Supperior, and Hud. fon's Bay, but thefe are comparatively Imall. As they lie out of the track that I purfued, I Inall only give cummert account of them. $I$ be moll wellerly of thes 
ufcarories, iglifis : the and St.

le two lat nited in the er a patent Ferdinando tad of that of the fame e countries miles from $t$ and fouth continuing to the mid. ounded; by take their hich lies at and from river till it

name of tho tlemen, on palties ; but a the fulfil. only could

thele part een the fet. e Indianin, b) the real owns have ers of lats bple by the ories, which

north of and Hudo As the 1) give : Jy of ches

\section{CATVR NTRATRES}

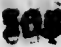

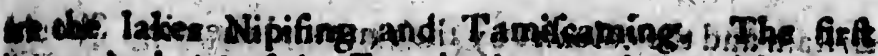

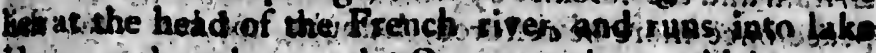

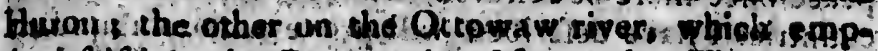

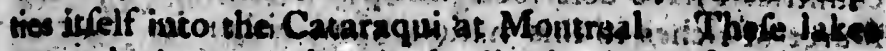

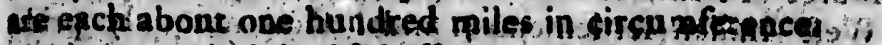

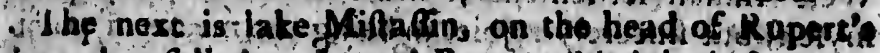
siver, that falls into Jumes' Bay olcthis lak is fo irres whar from thetarge poins of land by which in in inger.

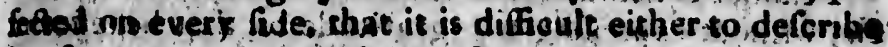

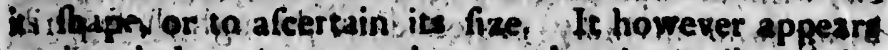
Qo the yhole to be more than two hurdrod miles in pir cumference.

Lake st Jobn, which is about eights malles round, and of a circular form, ties on the Saguegnay triver, di. realy north of Quebec, and falls into the St Lawrence, fomewhat norch eaft of that city. Lake Manikoulagone lies near the head of the Blact river whigh emplies its felf into the St Lawrence" to the eaftward of the lat meationed river, near the coall of Labrndor, and is a. biut fixty miles in circumference. Lake Rertibi, lake IVincktagan, lake. Etchelaugnn, and take Papenouigane, nith a number of other fmull lakes lie near the heade. of the Buttard river to the north of the St. Lawrence.

Many others which it is unneceffary to particularize bere, are also found between the lakes. Huron and $\mathrm{On}$. urio.

The whole of thofe I have enumerated, amounting to upwards of twenty, are within the limits of Canada : and from this accivunt it might be deduced, that the mitliern parts of North tmerica, through thefe numer. ous inland fe.ts, contain a greater quantity of water than. any other quarter of tlise glcbe.

In ()abober 1768 I arrived at Boflon, having been abfent two yeart and five monchs, and during that time. travelled near leven thoufarad miles. From thence, as foon as I had properit digefted my journal and charts, I fet out for Engind to communicate the dilcoveries I had made; and to render them beneficial to she king. dom. But the profecution of $\mathrm{my}$ plans for reaping thefe advantages have hitherto been obltructed by the unhap. pr divilions that have been fomentad between Greak 


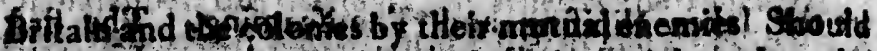

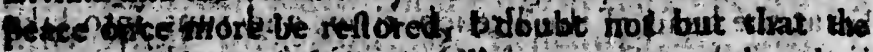

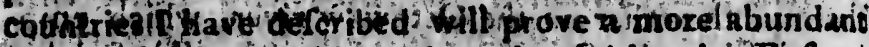

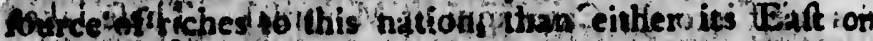

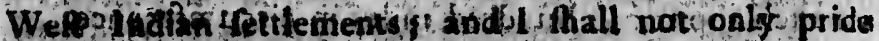

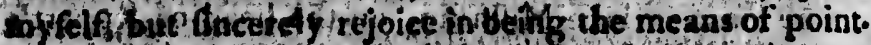

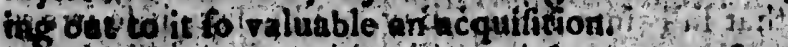
Th Niwithout exprelling my gratitude to duat benefoent

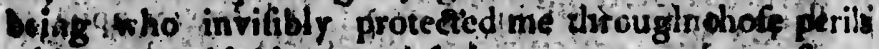
Whioh udabidably hecend fo long a tour antiong fierce and untutored favages.

a)rotition 4h Ac the the time let the notbe accufed of vanity or prefumption, if II declare hat the motives alledged in the introdlugion to f this work, were net the only anes that induoed me to engage in this arduous undertaking: Mr tew wert tho rotelt colfined to the advantages that aretue either to w f felf, or the commanity to which I belohged o but tobles par pofes contributed principal. If to uige me on

The confined Gate, hoth with regard to civil and re. ligions itmptovements, in which fo many of my fellow creatures remained, aroufed within my bofum an irre. tifible inctivation to explore the almoft anknown re. gions whiwh they inhubited; and as a preparatory ftep cowsicts the introduction of more polithed manners, and move hutmane fentiments, to gain a knowledge of their language, cuforms, and principles.

1 confess that the little benefit too many of the In. dian nations have hitherto received from their inter. courfs with thofe who denomiaale thenffelves Chrilians, did not tend to encourage $m y$ charitable purpoles : yet difmany, though not the generaliry, might receive fome benefit from the introduction among them of the polity and religion of the Europeans, without retaining only the orrors or vices that from the depravity and perver. Goo of their profeffors are unhappily attendant on thefe, I. determined to perfevere.

Nor could I flatter myfelf that is thould be able to accomplith alone this great defiga $;$ however, I was wil. Ning to coutribute as much as lay in my.power towards

it. In and fur what ft

It is of relig great cI tions wi but thei Jets as c opinioni lency in nine an pure an vine in that fup torality and ben their im banners -ffem $x$ of point may be but of $\mathrm{s}$

seg. 
4) Shoustd trthat the Inbundario as teart on oalts prids is of point. it it tom nfret travi benéfetnt thof perila rong fierce i) Evanity or illedged in fonly ones idertaking: advantages ty to which 1 principal.

ivil and re. fmy fellow im an irre. known re. ratory ftep anners, and Ige of their of the In. heir inter. Chrillians, poles ; jet ceive fome f the polity aining only and perver. at on thefe, be able to , 1. way wil. er tuwards it. In all public idertakings would every one do this, and furnifh with crity his particular thare towards it. what Atupenduovs works might not be completed.

It is true that the Indians are not without fome fenfe of religion, and fuch as proves that they norlhip the great creator with a degree of purity unknown to nations who have greater opportunities of improvement but their religious principles are far from being fo faultlets as deferibed by a learned writer, or anmixed with opinions and ceremonies that greatly leffen their excellency in this point. So that could the doctrines of genuine and vital clitiltianity be introduced among them, pure and untainted, as it flowed from the lips of its di. vine inftruetor, it would certainly tend to clear away that fupertitions or idolatrous drofs by which the rathomality of their religinis tenets are obfcured. Its mild and beneficent precept would likewife conduce to foften their implacable difpolitions, and to refine their farage manners; an event moft defirable; and happy thall I clecem myfelf, if this publication thall prove the means of pointing out the path by which falutary initructions may be conveyed to them, and the converfion, jhough. bat of a fev, be the confequence.

gencherron or The Jounus $L_{2}$ Eo. 
tote

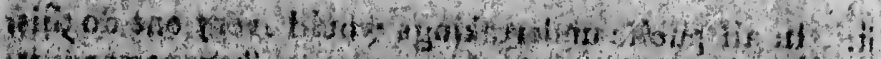

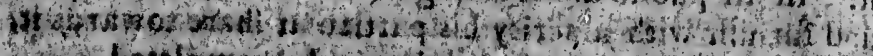

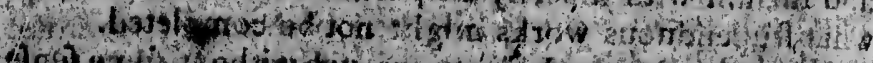

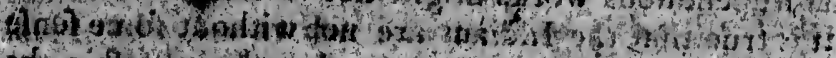

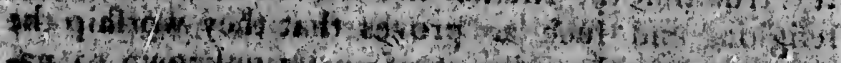

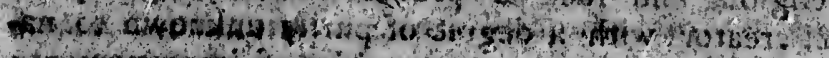

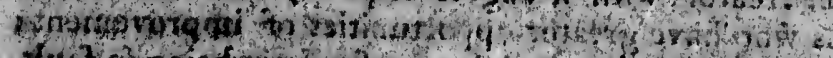

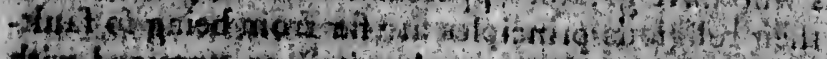

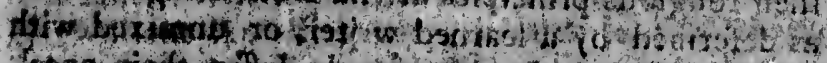

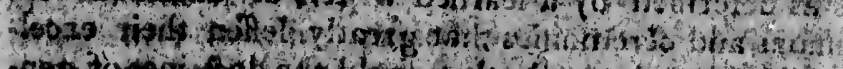

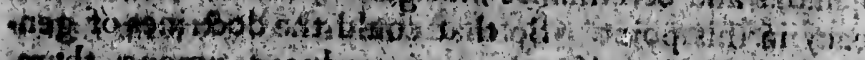

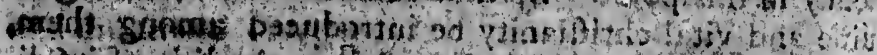

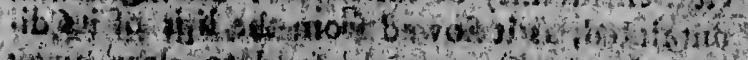

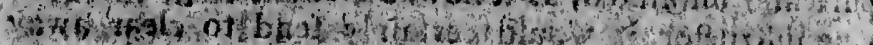

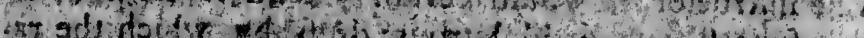
the

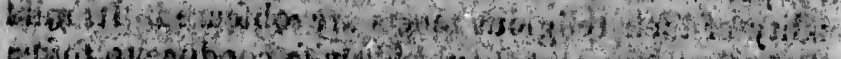

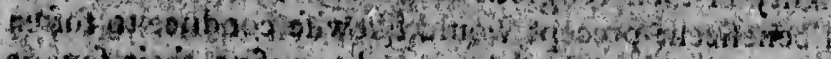

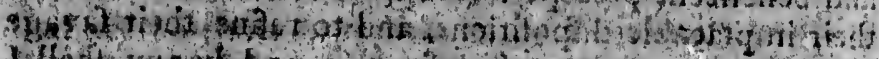

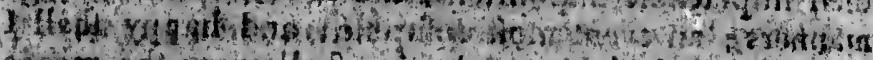

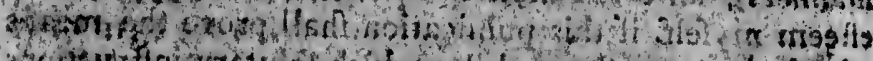

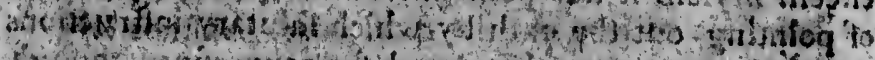

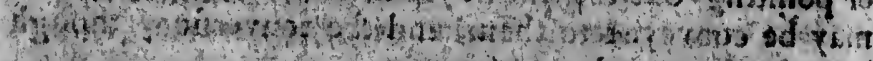

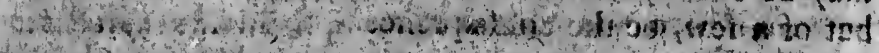

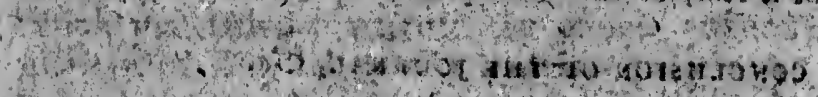
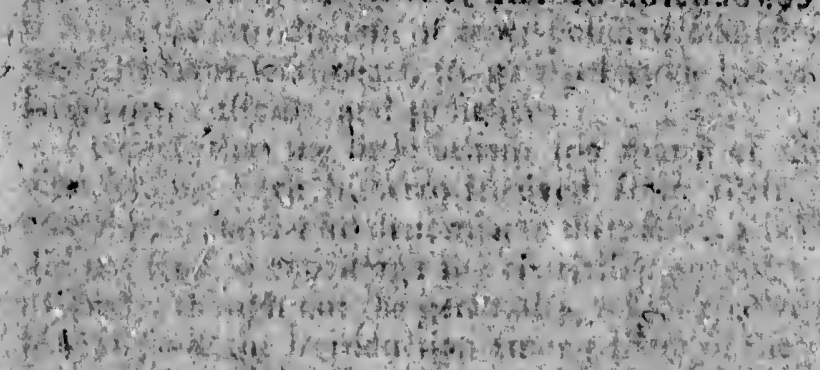
is $41+.3 i$ muntwy सी int? by 67. 3xt a ritidy test futshy

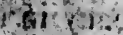
bis: Wit sth (ritist $9 x+5$ ini ies rrotin $\mathrm{xa}$ $\pi$ rriosts intiton to $2 d \sin$ azon

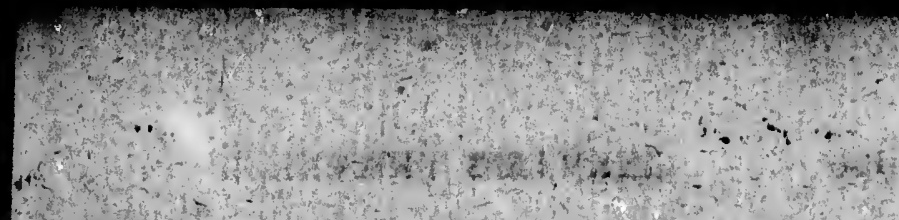

ot TuE

QRIGIN, MANNERS, CUSTOMS,

RLIGION AND LANGUAGE

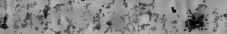

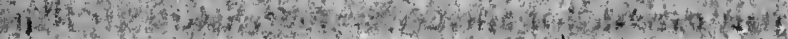

of Th:

\section{INDIA NS.}

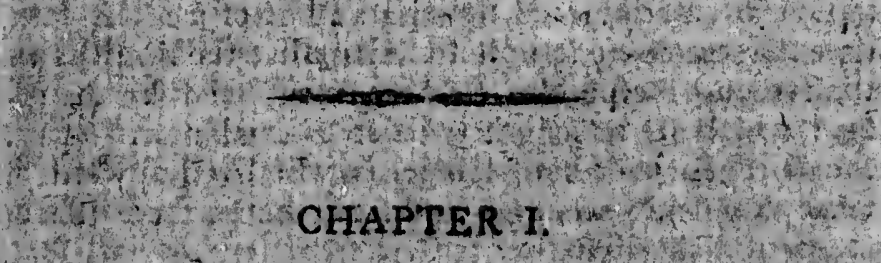

\section{W OE THETR ORTGINA}

$\mathrm{T}^{4}$

H. B mears by which America received in firn in habitants, have fince the lime of its dicovery by the Wuroperins, been the fubject of numberlefs difquititions. Whs 1 ro endeavor ta collect the different opininns and reafoning of the $y$ aricus w rlers that have taken up the pen in defence of their conjesturs, the enumeration would minch exceed the hounds 1 tave préreribed to myt falt, and oblige me to be lefs explicit on points of grent. ct motrent.

Trom the ob curty in which this debate is enveloped, through the total dilue ff letters anorite every natioh of Indians un this texterfive contment, and the ulicertaint of oral tradition at the diffance of fo twany ages, I feat, that even afted the mon minate inveftsation; we liail not be ablét fettle it yith ary g reat degre of certainty. And this appreheufion will isceire additional force.

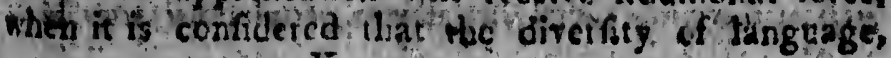


which is apparently diftinet between moft of the Indians, tends to afcertain that this population was not effected from one particular country, but from feveral neigh. boting ones, and completed at different periods.

Molt of the hiforians, or trayellets that have treated on the American Aburigines, difagree in their fentiments relative tothm. Many of the ancients are fup pofed to have known that this quarten of the globe not only exifted, but alfo that it was inhabited. Plato in his 7 Timeus has afferted, that beyond the ifland whtth be calls Atalnntis, and which, according to his defcription, was fituated in the veltein ocean, there were a great number of other illands, ahd behind thofe a vait conti. nent.

Oviedo, a elebrated Spanith author of a mach later. date, bas made no feruple to affirm that the Antilles are the famoug. Hefperides fo often mentioned by the po ets ; which are at length reftored to the kings of Spain, the defcendants of king Hefperus, who lived upwards of three thoufand years ago, and from whom thefe Iflando received their name.

Two cther Spgniards, the one, father Gregorio Gar. cin, a Dominican, the other father Jofeph De Acolta, a Jefuit, havewritten on the origin of the Americans.

The former, who had been emplayed in the niffion of Mexico and Peru, endeavored to prove from the tra ditions of the Mexicane; Peruvians, and others which he received on the fpot, and from the variety of charac. ters, cultams, languages, and religion obsrvable in the different countries of the new world, that difierent nations hed contributed to the peopling of it.

- Thelatter, father De Acula, in his eramination of the means by which the tirf Indians of A reerica might hove found a palfuge to that continent, differedits the conclufions of those who have fuppoled it to be by fea; becaufo no encient author bas made mention of the compafs and concludes, that it maft be eithet by the north of Afra and Europe, which adjoin to each other, or by thofe regions that lis to the fouthward of the Stroits of Magellan. Ile alfo rejects the uffertions of fuch as lave advanead that it was peopled by che Hoo brewe.

John d] ppinions Thohave he ences peopled tonathats difipertion thet the Gmblanc bat alfo: Bes Sogth oller nat theof the Norw land, and inowen th ost 8 and Chiobirmi He 4 ids radicion fors the the trigh Anotice could tee Groenlun Nitur $n$ fothe Chichimi Wha had - of Mexic liar to th pofidre Californi the mopt frome Ni D. I webiring tho int ation is vinum Coir en 
Indians, effected i) neigh.

8.

e treated ieir fenti. are fup lobe nos ato in his which be feription, great ift conti.

uch latet. ntilles are $y$ the po. of Spain, ?wards of Ce Itando rio Gar. Acolta, 2 cans.

million the tra which he f charac. le in the rent na

bation of ca might dits the by fea; $x$ of the abj the 3 other, 1 of the stions of the Ho.
Johr de Iaet, a Flemifh writer. has controverted the opinions of thefe Bponith fathers, and of many orbers thohare written on the fume fabject. The hyporhefis he endeavorn to efablih, is that i merica was certainly peoplad by the Sejthians or Teartars : and that the tratfuigration of thefe people happenod foon after the diperfion of Noath's grandfoxis. He nadertakes to thow that the moft nothern Ameriesh bave a greater reGomblences, nor only in the fentuset of thotrscountenances, but alfo in their complezion and manner of living, to

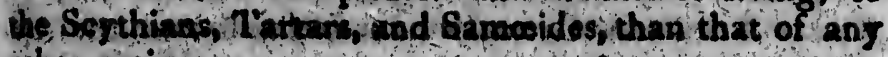
odier mations.

In onfuer to Grative, who had afferted that fome of the Norriegiana pafled into A merica by way of Groen. land, and over a vaft continent, he fare, that it is well thoosn that Greenland oas not difcolfexed sill the year

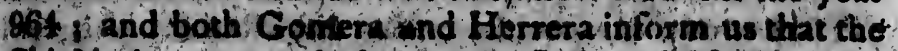
Chiobitmiques wero frutted on the Lake of Merico 721 . Ho dids that thes frvayes according to the uniform

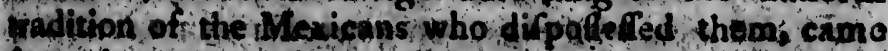
form the country ftnes called New Merich and from Ale Nighborhagd of Californin t confequentis North A perice wuth heve been whabited many ages before it could tective an t i habitants from Normay by wat of Greenlund.

Wi no lefs certains he abferves, that the veat Mexicans Found dhit empin in $20 \%$ after having fabduct the Chichiniques, she Ornwintand other barbanous nations. wha had cakes poffeffon of the couptry round the Lake -of Moxiea, and each of whom fpoke a inguage pecnliar to themfelves. The real Meticans nto like wife fup. pofed to como from forth of the countried that lie near California, add that ther performed heir journes for the moft pare by land of courf whey could not come from Normay.

D. Lnet further adds that loough fome of the in-

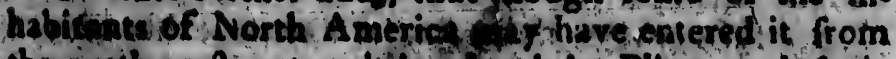

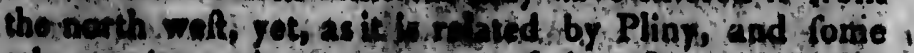

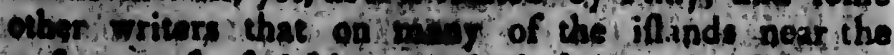

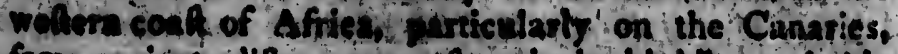

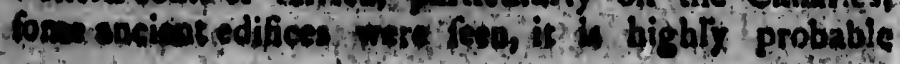


from their boing now delerted that the inhabithts may have paffed ofer to A merica, the palfage being neithet long, uo difficult this migration according to the calculation of thofe autlior,, nutit have happoed more than two thoughd yedrs ago, at a time vithen the span. iards vere much troubled by the Carthagenions 7 from whom laring obtribed 2 knowledge of navtgation; and the confruetion of thips, they might have retired to the Antiles, by the way of the weftera ifles, which were ox atly half way on their stojege.

He thinks that Great Britain, Jreland, and the 0 . - cades were extremely proper to admit of eftuikt con. jecture. As a proof, he intenta the following parage from the hiftory of Wales, writen by Dh Davidrowel, in the year 1170

This hiftoriun faje, that Madoc, one of the fons of Bince 0 wen Gw gunith being difuled atrithe civil Wurs whih brole out bet weentis brothern oftr the

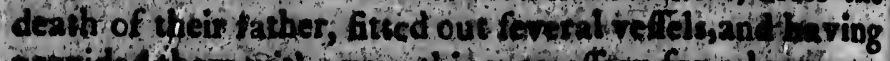

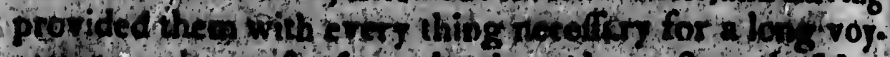

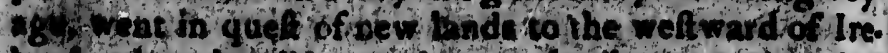

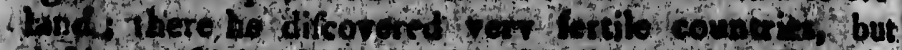

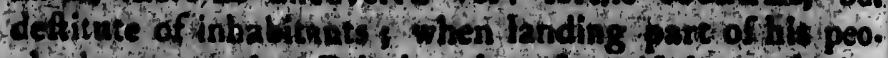

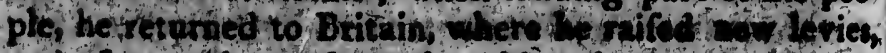
and after warde tranfported to this solony of th Aiv

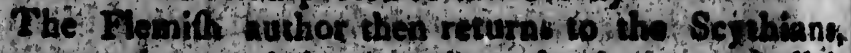

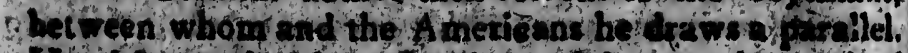

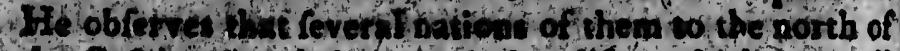

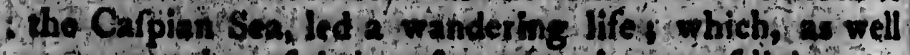

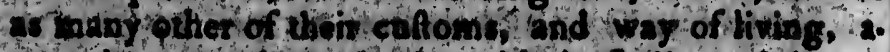

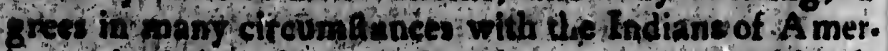
ica. Ald diough the refemblances ate not abolutely

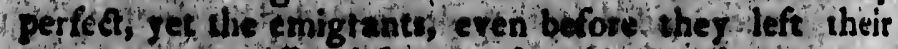
own country difsed ftom gach other, and weat not by the fame, name. Their change of abode efiefted what remained.

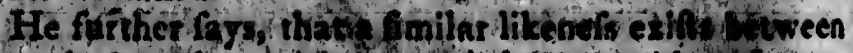

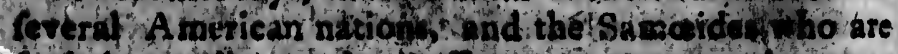
fetledaccotdingto the Keman accounts, on the great

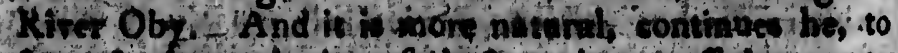

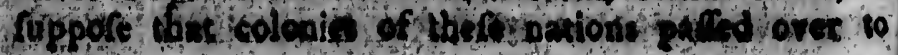

Amotic foritho marked This: qualbin termixer Emat Brazili, by the proofin knowint! of Afric by the de in the t all comn of many. As to thi circentracil tefemblai

Georg vife writ ing that haveliees fpace of world an hetéys is and other tro hoth and fome et by figt on the ro dcean.

if f가 furt a free palf horfes or phanct $\mathrm{c}$ kinds $)$ veredithe convenieńc Having hive ndm 


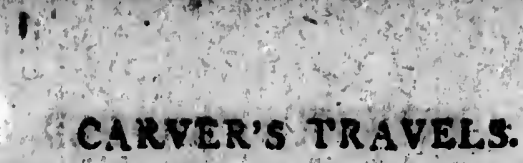

tats may 8 neither 3 it to the led more Span: is $y$ from tion, and ed to the weré $x$. the Or. ailat con. spaflage idreomel,

C fons of the civil offor the i) lowloo: wd o lre. $t+$ but Alitipeo. int isties. Whin

ichetions: spindel. courth of potevell iving, 2 . of A merbifolutely left their weat not - eficted

croween Wwho are ther great a the; 10 over 10
Amorica by cruffing thetict fea on their fledges, than for tho Norwogians to travel all the way Grotius has marked out for them

This writer males many other remarks that are e. qually rentible, and which appear to be juf, but he in: termixed with there fome that are not fo well founded. Emanuel ze'Moraez, a Pottuguefe, in his hiltory of Brazil, afferts that A merica has been wholly peopled by the Carthagenians and Ifraelites. He brings as a proof, of this affertion the difcoveries the former are knowin to have made at a great diftance beyond the coaft of Africa. The progrefs of which being put a ltop to by the fenate of Carthage; thofe who hapened to be then th the newly dilcovered countries, being cut off from all communication with their countr menen, and deflitute of many neceffaries of life, fell into a flate of barbarifm. As to the Irrelites, this author thinks that nothing but circetucifion is wanted in order $x$ conllitute a perfec refemblance between them and the Brazilians.

George De Hornn, a tearned Dutchman, las litewife written on this fubjed, He fets out with tectarthi, that he dues not believe it poffible America could bave been peopled before the food. cnnfidering the fhort Space of time which elapfed betwcen the creatin n of the world and that memorable event. In the rext place hellays it dowa as a principle, that after the delige, men ma other terteftrial animals penetrated into that countr both by foa and by land, foms throngtr accident, and come from a formed delign. What birds got thith. or by flight which thes were enabled to do by reltitg or the rocks and,ilands that are feattered about the ocean.

Fle further obTetves, that wild beals mag, have found 2 free paffage by land, and that if $v e$ do tot meet with horfes or cautle (to which he might have added elephants, carmels thinoceros, and bealty of many other binde) te is becaufe thole nations that pafied thither. ware cither not acquainted Ith theit ulf or had no convenience to tuppore therin.

Having totally excluded many nations that crlers thavendmitud as the probable Grit fetthro of Amedica
(a) 
104 THRYHETRAVELS.

for which he gives fubflantid teaforis he fupposes that Ait began to be peopled by the narch, and matains the primicive colonies fpread themfelves by the means of - the ithmus of $P$ anama through the oblole extent of the continent

He believes that the finf founders of the Indian col. onies were Scythians Mat she Plunicians end Car. chagenians afterwarda got footing in America acrofs the Allantic Ocean, and the Chinefe by way of the $P_{2}$. cific And that other nations might from time to time have landed there by one or orher of thefe ways, or might poffitly have been thrown on the coult by tempelts: fince, throgig the whole extent of that contingn, bath in its northern atud fouthern parts we meet with undoubted marks f 2 mixture of the northern nations with thof who have cotre from other places. And lafly, that fone Jews zed chriltians might have been carried there by fuch like events, but that this muff have happened at 2 time when the whole of the new Worbl was alteady peopled.

Thet all, he acknow edges that great diffculties at. tend the deter mination of the quelion. IJ befe, he fays, aie occafioned in the finf pla ce by the imperted knowl. edge we have of the extretnities of the globe, towarts the north and fot th pole, and in the rext place to the hivoc which the Spanjards, the firf difcoverers of the new wrld, made among its wolt ancient monuments; as withers the great double rond betwixt Quito and Cueco, oth undertaking to fupenduovs, that even the mof magnificens of thofe executed by the Romans can not be compared to it.

He fuppofes alfo another migration of the Phonicians, than thofo already mentioned, to have taken place, ond this was during a three years royage made by the 1 s rian fleet in the fervice of king solomon. He afferts un tho authority of Jolephus thet the port at which this embarkation was made, lay on the Medtartanean. The fiet he adds, went in quelt of elephant th and peacocks to the weftern coalt of A frica, which is lar fin, then to Ophir for gold, which is Haite, ot the ill atd or Etirpaniola $;$ in the lattet opinion to is fupport

ad ore chought? nas reño

To th era, he a nations, ! the friase writers 0 onlygivi

The, fir mani whi cxistoade the apini which he litter cal they are 1 that it req

He feel cadits firf This be c which wre thofe cov thathe Hexhen: Aory $1 \mathrm{~h}$ Grollon; fac:

This of mitions Qnedas ron wom Healied into 2 cor fuet, that dugted fro plice af

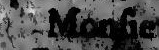
atro turinfrom of esspan taluen by 
tofes that atains the means of ent of the

Idian col. and Car. ca acrofs of the Pd. Deto.time or might iempelts: ant, bath with unnn nations es. And bave been this mutf the new

culties at. Revine fan, celknowl. towards ace to the ers of the numents; Quito and Eeven the mans can

he Phoniken placs due by the He'allerts at which rextanean. th and ch is l'ar. or the in. cupport ad oy Columbus, who, when be difcovered that illatid; thought heicauld trace the furnaces in which thi geld was refíaed.

To thete migrations whidh preceded the chriftin era, he adds many others of a later date from diffent nations, but thefe I hare not time to enumerate. For the Came reafon I a mo obliged to yafs over numbrlefs mrikets on this fubjef, and thall content m f felf with inly giving the fentiments of twa or three more.

The firf of thefe is Piorre De Charlevoix, a Frenchmans who, in his journal of a voyage to North A meticas toade folately as the year 1720 , has recapitulated the apinions of a variety of authors on this head, to Which he has fubjained his ovn conjectnres. But the latter cannot without fome difficulty be extracted as they are fo inter wanen with the paffages te has quorted, that it requires much attegtion to difcriminate them.

He feems to allow that A merice might have receir. cd it frft inbabitants from Tartar and $H$ rrcania. This he confitms, by oblerving that the lives and tiger. which we found ia the former, muf have cpmo fom thofe countries, and whofe paffage ferves for a proof Whe the two hemitpheres join to tha north ward of $\mathrm{Xfi}$. Howen drins a corroboration of this argument, from a flory be tays be has often heard relited by father Goullon; a French Jefuic as an unduubted patter of fae:

This father, after having labored fone time in the mitions of Nee Erance, paffed over to thofe of China. Que dar as he wes travelling in Tartary, he met a Hu. ron woman whot the had formerly known in Canada. He aljed beriby what adventure she had been carried into a counery fo diftant from her own. She made anfrer, that having been taken in wor, the had been conducted from nation to nation, till the bad reached the place af which the then was.

Nor feur Churlevoix fugs turther, that he had been afforf thother Jefuit, palling through Nantz, in his re: turn from Chin, had elated much fuch an other affair of a Spanilh wotnan from Florida. She alfo had been talen hy certain Indians and given to thofe of a more 
diflat conntry \& and by thefe again to anchet nation ill having thus been fucceflively paffed from country to country, and travelled through regions extrendy cold, the had at laf found herfelf in l'artary. Heie Ohe had married a lartar, who bad attended the cono querors in China, whert the was then retcled.

He acknowledges as an allay to the probability of thefe foris, that thote who had failed farthef to the eafty drd of $n$ lia, by purfuing the codil of Jeflo, or Kamichatka, bave pretended that they had perceived the extremity of this continent 3 and from thence fiar concluded hat there could not pofibly be any cotnmo nicatiun by land- But he adds that Francis Guella, 4. Spaniard, is faid to have aferted, that this feparation is no more than in frait, about one bundred miles over, and that fome late voyages of the Japanefe give grounds to think that this Arat is orly a bay, above which there is a paflage over land.

He goes on to obferve, that though there are few wila beffs to be met yith in Norch A mierica, excep A th of tigers without fpots, which are found in the coptry of the Iroquois, jet towards the tropics there ore lions snd real tigers, which, notwithltanding, might have come from Hycania and 7 artary t for as by ad. Yanging gradually fouthward the mot with climate nore agreeable to their natures, the bave io time 2 bandoned the northern countries.

He quotes both Solinus and Pliny to prove that the Scythian Anhropophagi once deponutated a great ex. cent of couytry, as far as the promontory Patip ; and ifo an author of later date, Mark Pat a Venetian; who lo fayg tels ns, thet to the north ent of China and Tartar tere are vaf uninlubited conatries which might be fiff cient to confirm an sonje dures concern. ing the retreat of a great number of Sorthians into America.

Io this he adds that we find in the ent nts the names of lonte of thefe nivions ofting lo at the Tabians Solinus mencions the Apuloan 3 , go had fo: ueighbors the Matfagetes, whom Rling fine bitures as 4 have entirely difupared Anminens Marcelliaus

Nothin tive finft.

diree athe tries ba plea deem (0., $1 \mathrm{hol}$ the defcen mankin o polople opled

Tobrin rificultios pres. We poptog the tran onfiderabl wer into $A$ How thin thef witoty boreah suresinte $k$ Nideriand tathe fo aricing

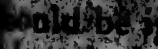
trobses $7 \mathrm{n} h \mathrm{f}$-m teatchat 
er nation a country extremely 7. Here d the con.

bability of eft to the Jeffo, or perceived ience tiare ry cotinmiv. Guella, Ceparaticn miles over, e grounds hich there

te are few icar except und in the opics there ing, night as by ad. h climates in time 2.

that the - great ex. hith and tian, who, china and es. which 3 concernhlans into

tonts the itof the Le had for Gltaresius arcellinus aprefsly tells us, that the fear of the Antropophazind. Wiged fereral of the inhabitants of thofe countries to take refuge elfewhe:e. From all thefe authoritio Hons. Charlevoix concludes, that there is at leatt room to conjectuie that mare than one nation in America had Scjthian or Tartarian original.

He finilbes his temarls on the author' he has quotd, br the following obfervations - It appears to me that this controverf una be reduced to the int following articles, At t hot the new porld might have been poopled, and fecondly by whom, and by what means it has been peopled :

Nothing te afferts, may be more eafily anfwered than Whe fint Amerien might have been peopled as the. three ather parts of the wortd have been M Many diff. mitics have bien formed on this fubjed. whigh have Wen decmed infolvables bue which are far from being (0. 1 he iahabitante of both hemifpheres are certainly the defcendant of the fame father; the common parent mankind received an exprefs comitund from bearen o pabluthe whale norld, and accordinglf it ha, 40 upledis nol

To bring this about it was neceliary to a trcoms all Hificlues that lay in the wat, and they bave been got ger. Were there diffeulties greater with refpet to opling the extrethives of Alf, Africas and latrope, the tranfporting wen wio the fiflends which lie at a onfuerable difance from thofe continents, than to pars Mer into A verica 1 cctainls not.

Whagation, which bas anrined at fo great perfection

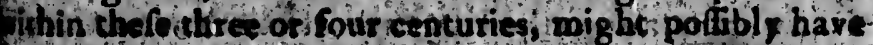
th thoto perfect in thote early ages than $n$ thits $12 y$. ho can beliere that Nha and his immoliater de. oudsint knew lers of this ant than we dot That the Mtor and pilot of the largeft thip that ever was, a fhip th the formed to thaverfe an unbounded ocean, and

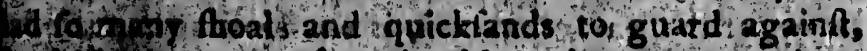

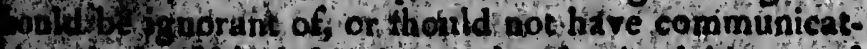
dth o o his defceadanis who furkiked bim and 7 wo - means he was ito gxecute the arder of the

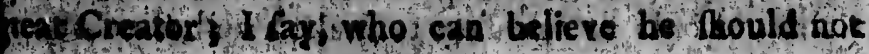


have communicated to them the art of failing upon an ocean, which was not only more calm and pacific, but at the fame time confined within its ancient limits?

Admitting this, how eafy it is to pafs, exclufive of the paflage atready deferibed, by land from the coalt of $A f$. rica to Brazil, from the Camaries to the weftern Ifland, and from them to the Antiles? from the Britifh Ifles, or the coaft of France, to Newfoundland, the paffage is neither long nor difficult; I might fay as much of that from China to Japan; or the Philippines; to the Ifles of Marianines and from thence to Mexico.

There are illands at a confiderable ways from the continent of Alia, where we have not been furprifed to find inhabitants, why then fhould we wonder to meet with people in America I nor can it be imaginedi that the grund fons of Noah, when they were obliged to fep. arate, and fpread themifelves in conformity to the defign -f God, over the whole earth, thould find it abfolutely impolible to people almo' one half of it.

I have heen nre copious in my extracts from this author then I intended, as his reafons appeas to be fol. id, and many of his obfervations jult. From this enco. mium, howrever, I nuft exclude the ftories he has intro. duced of the Huron and Floridan women, which I think I might venture to pronounce fäbulous.

I thall nuly add, to give iny readers a more compre. henfive view of Monfienr Charleroix's differtation, the method he propofes to come at the truth of what we are in fearch of.

The only metans by which this can be done, he fays is by comparing the language of the Americans with the dificreti nations; from whence ve imight fuppof they have peregrinated. If ve compare the forme with thofe words that are confidered as ptimitives, $i$ might podibly fet usippon fome happy difcovery. An this way of afcending to the original of natious, which is by far the leaft equivocal, is not fo difficult as might be imagined. We have had, and ftill have, traveller and millionaries who:have attained sthe languages the are fpoten in all the provinces of the ner world it riould only be neciffary, to make a colleation of thei

the dead pafs for. triced. iations mother to Anyes traditions means the A difquif of proiluc make us with cert? Ancien weither $h$ ont thofe in this fitu rents, and maditions, aifaced in ed, there $n$ cions; and

He cone many othe rrecks, ha table part bis, at per and manne atch otber. porder on 1. monum dige of $t i$ byowing a larknefs.

B) this hat prodig America, therer, whic nd entirels tho confeq America 
upon an acific, but mits ?

Give of the sat of $A$. in Iflands, itith Itles, paffage is ch of that the lifes

from the urprifed to er to meet ginedi that ged to sep. the defigns absolutely

from thiv as to be folo $a$ this enco. e has intro. hich I llink

pre compre. tation, the of what we

le, he fays, ricans with he fuppose the former timitives, i: rery. And ious, which It as might 3, travellers yuages that hein world ion of theil rammers and vocabularies, and to collate them with the dead and living languages of the old world, that pafs for originals, and the fimilitarity might eafily be treced. Even tle different dialects, in fpite of the al. trations they have undergune, Atill retain enough of the mother tongue to furnift confiderable lights.

Any enquiry into the manners, cuftoms, religion, or thaditions of the Aroericans, in order to difcover by that means their origin, te thinks would prove fallacious. A difquifition of that kind, he obferves, is only capable: of prorducing a falfe light, more likely to dazzle, and to make us wander from the right path, than to lead us vith certainty to the point propofed.

Ancient traditions are effaced from the minds of fuch deither have not, or for feveral ages have been with. wit thofe helps that are neceffary to preferve them. And th this fituation is full one half of the world. New ea rents, and a new arrangement of things, give rife to new taditions, which efface the former, and are themfelves af aced in turn. After one or two centuries have parf. did there no longer remain any traces of the firft tradi. lions; and thus we are involved in a ftate of uncertainty. He conclides with the following remarks, among many others. Unforefeen accidents, tempeits, and Thipwrecks, have certainly contributed to people every habtable part of the world : and ought we to wonder afser. this, at perceiving certain refemblances, buth of perfons and manners between nations that are molt remote from ach other, when we find tuch $\alpha$ difference in thofe that border on one another? As we are deftitute of hiftoric1 monuments, there is nothing. 1 repeat it, but a knowl. dige of the primitive languages that is capable of thowing any light upon thefe clouds of impenitrable tarknefs.

By this cnquiry we flould at leaft be fatisfied, aning that prodigious number of various nations inhiabiting America, and differing fo much in languag es tiom each ther, which are thrie who make ufe of words totally Wd entirely different from thofe of the old world, and tho confequently muft be reckoned to have paffed over America in the oarlieft ages, and thofe, who, from 
the analogy of their language with fuch as are at pref. ent ufed in the three other parts of the globe, leave room to judge that their migration has been more re. cent, and which ought to be attributed to thipwrecks, or to fome accident fimilar to thofe which have been spuken of in the courle of this treatife.

I Thall crity add the opinion of one author more, be. fore 1 give my own fentiments on the fubject, and that is of James A dair, ef q. who refided torty years among the Indians, atid publifhed the hiffory of them in the year 1772. In his learned and fy fiematical hiftory of thofe nations, inhabiting the weftern parts of the molf fouthern of the American colonies; this gentleman without hefitation piononnces that the American abo. rigines are defcended from the Ifraelites, cither whilt licy were a maritime power, or foon after their general captivity.

This defcent he endeavors to prove from their relig. icus tites, their civil and martial cuftoms; their mariag. es, their finetal ceremonies, their manners, language, traditions, and frem a variety of other particulars. And fo coniplete is his conviction on this head, that he fan. cies lie finds a perfeet and indifputable fintilitude in each. Throing all thefe 1 have not ima to follow him, and thall therefore only give a few cxtraets to fuow on what foundation he builos his conjectures, and what de. gree of credit he is entitled to on this point.

To hegins with obfeivig, that thongli fome have fupuocd the Asicticans fo be defended frrin" the Clinefe, yet reither their yeligh n, liws nor cultong agree in the lealt with thofe nt the Chinde, which inficiont.

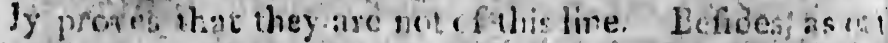

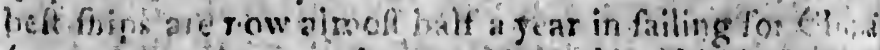

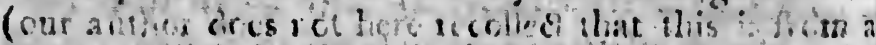

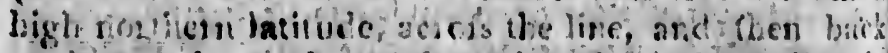

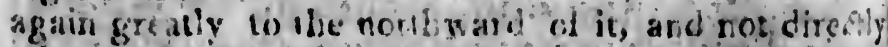

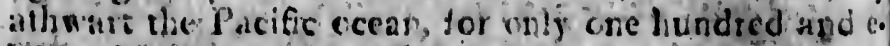
leyen degrees) a from liclice on Evinpe it is very un.

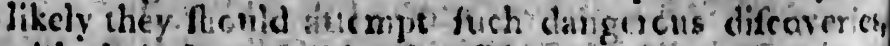

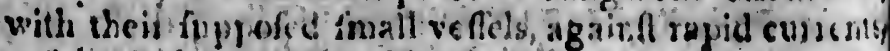
apd in daik ind lickly Moofoons. 
He turther remarks, that this is more particulaily

re at prefo be, leave more re. hipwrecks, have been

more, be. $t$, and that ars among. em in the I hiltory of of the molt gentleman erican abo. ither whill ieir general their relig. eir mariag. language, ulars: And iat he fan. trillitude in follow him, to fluow on d what de.

fone have me Clin. rons agec infficiont ibes: as 1 g ro: $<1, \ldots$ frim a When birk not diresty bied und e. is very un. difcareres, id cuisosily improbable, as there is reafon to believe that this nation was unacquainted with the ure of loafitone to direet their courie. China, he fays, is abont eight thoufand miles dillant from the American continent, which is twice as far as acrols the Atlantic Ocean. And we are not inturmed by the ancient writer of their maritime skilt, or fo much as any inclination that way, befides fmall coafting voyages. "The winds blew iikewife, with little variation from ealt to weft within the latitudes thirty and odd, north and fouth; and therefore these could not drive them on the A merican coaft; it ising di. rectly contrary to fuch a courfe.

Neither could perfons, according to this witer's account, fail to America from the north by the way of l'artary or ancient Scythia ; that, from its fituation, never having been or ean be a mariiime power; and it is utterly impracticab!e, he fays, for any to corre to $A$ merica by fea from that quarter. Befides, the remaining traces of their religious ceremonies and civil and niartial sulloms are quite oppolite to the like veftiges of the bld Scythians. Even in the moderate northern climates there is nut to be feen the leaf trace of any ancient Rately buildings, or any thick fettlements, as are faid to remain in the lefs healthy regions of Peru and Mex. ico. And fereral of the Indian nations a fiture us, that they croffed the Miffifippibefore they made their prefent northern fettlements; which connected with the for: mer arguments, he conclucies. will fufficieutly explode that weak opinion of the American Alorigines being lineally defcended from the 'lartars or aucient Scy. thians.

Mr. Aduir's reafons for fuppofing that the Americans derive their origin from the Jews are,

liirf, becaufe they are divided into tribes, and have chiefs over them' as the If raclites had.

Secondly, becaufe, as by a frict parmanent divine precept, the Hebrew nation were ordcred to wirhip,at. Jerufalem, Jehovah the true and living God, fo do the Indians, Ailing him Yohewah. The arcient Heathens, he adds, it is wcil know'n worniped a plurality of gady,- 
but the Indians pay their religious devoirs to the Great beneficent tupreme holy Spirit of Fire, who refides as they think above the clouds, and on earth alfo with un. polluted people They pay no adoration to images, of to dead perfons, neither to the celeftial luminaries, to evil fpirits, nor to any created beings whatever,

Thirdiy, becaufe, agrceable to the theocracy or divine government of Ifrael, the Indizins think the deity to be the immediate head of their liate.

Fourthly, becaufe, as the Jews believe in the minis. tration of angels, the Indians alfo believe that the high. cr regions are inhabited by good ipirits.

Fifthly, becaufe the Indiun language and dialects ap. pear to have the very idium and genius of the Hebrew. 'Their words and fentences being expreffive, cencife, em. phatical, foriorous, and bold; and often; both in letters, and fignification, are fynonymous with the Hebrow language.

Sixthly, becaufc they court their time after the man. ner of the Hebrews.

Sevetitlily, becaufe in conformity to, or after the man. ner of the Jews, tliey have their prophets, high priefs, and other religious orders.

Eightlily, bccaute their feltivals, fals, and religious rites have a great refenblance to thofe of the $\mathrm{He}$. brews.

Ninthly, becaufe the Indians, jefore ney go to war, have many preparatory cercmonies of purification and fafting, like what is recorded of the Ifiactites.

Tenthiy, becaufe the jame tafte for ornaments, and the fime kiad are niade ufe of by the Irdians, as by the Fiebrews.

Thefe and many other arghanents of a timilar nature Mr. Adair brings in fippurt of his favorice fyltem; but 1 thould imagine, that if the Indians are really derived from the Hcbrews, among their religious ceremonies, on which he rhictly leems to build his hy pothelis, the prin. cipral that of circumcifion, would never bave been laid aficie, and its very icmembrance oblitciated.

"Thus numerous and diverfe are the opiuions of thofe who hate litiserto written con this fubject! I thail not

however out the fentimen founded guments own obfi to the $j u$ The b it is nece merics a proach $\mathbf{r}$

The $c$

fromall ? appears of the $w$ nearelt ti Seventy within to red on th corilt of $C$ aboutécis the Braz tends to 1 north eal Siboria, i wards wi fornia to welt, and tude.

Wheth ther nort of Afia, the ivrite have beet an archip continen

It bein fidernblo fo and 4 Land, B Thabirikd 
the Great refides as 0 with un. mages, or inaries, to $\mathrm{r}$,

or divine leity to be

he minis. the high.

ialects ap. Hebrew. ncife, em. in letters, ebrew lan.

the man.

the man.

h priefs,

seligious $f$ the $\mathrm{He}$.

- to war, ation and

pents, and , as by the

lar nature tem; but $y$ derived monies, on - the prinbeen laid is of thofe thall not however either endeavor to reconcile them, or to point out the errors of each, but proceed to give my own fentiments on tlit origin of the Americans ; which are founded on conclufions drawn from the moft rational arguments of the writers I have mentioned, and from my own obfervations; the confiftency of thefe I thall leave to the judgment of my readers.

The better tointruduce my conjectures on this head, it is neceflars firf to afcertain the diftance between $A$. merica and thofe parts of the habitable globe that ap. proach neareft to it.

The continent of America, as tar as we can judge fromall the refearches that have been made near the poles, appears to be entirely feparated from the other quarters of the world. That part of Europe which approaches nearelt to it, is the coaft of Greenland, lying in about feventy degrees of north latitude; and which reaches within twelve degrees of the coaft of Labrador, ficun. ted on the north ealt borders of this continent. The coilt of Guinea is the neareft part of $\lambda$ frica ; which lies about eighteen luundred and fixty miles north eaft from the Brazils. 'The, mott eattern coaft of Afia, which ex. tends to the Korean Sea on the north of China projects north eaf through eaftern I'artary and Kamfchatka to Siberia, in about fixty degrees of north Jatitude.' 'I'iowards which the weftern coalts of America, from California to the Straits of Annian, extend nearly north weß, and lie in about forty fix degrens of the fame latitude.

Whether the co , inent of America Rreaches any further north than thele ftraits,and joins to the eaftern parts of Afia, agreeable to what has been afferted by fome of the iwriters I have quoted, or : whether the lands that have been dilcovered in the intermediate parts are only an archipelago of ifands, verging towards the oppofite continent, is not yet alcertained.

It being, however, certaip that there are many confiderable iflands which lie between the extremities of $A$. Ga and America, viz. Japan, Yefo or Jedfo;. Gamn's Land, Behring,s I Ie, with many others difcovered by Tsshirikow, and befides thefe, from fitty degrees north 
there appearing to be a cluter of iflunds that reach as far as Siberia, it is probalile from their proximity to America, that it received its firft inhabitants from them.

This conclufion is the mof rational I $\mathrm{am}$ able to draw, fuppofing that fince the Aborigines got footing on this continent, no estraordinary or fudden change in the po. fition or furface of it has taken place, from inundations, carthquakes, or any revclutions of the earth that.we are at prefent unacquninted with.

i'o me it appears highly improbable that it fhould have been peopled from different quarters, acrofs the Ocean, as others have alferted. From the fize of the fbips'niade ule of in thofe early ages, and the want of the compafs, it cannot be fuppoled that any maritime nation would by choice venture over the unfa:homable ocean, in fearch of diltant continents. Had this liowev. er been attempied, or had A merica been firt acridental. Iy peopled trom thins freighted with paffengers of both fexes; which were driven by ftrong eatterly winds acrofs the Atlantic, thefu fettlers mul bave retained fome traces of the language of the country from whence they migrated; and this finge the difcovery of it by the Europeans mult have been made out. It ulfo appears extrzordinary that feveral if thefe accidental migrations, as allowed by fome, and thêfe from different parts, thould have taken place.

Upon the whole, after the moft critical enquiries, and the maturelt deliberation, I am of opinion, that A mer. iea received its firt inhabitants frors the north eal, by way of the great Archipelago juit mentioned, and from thefe alone, But this might have been affected at differ. ent times and from various parts : from Tartary, Chi. na, Japan, or Kamfchatka, the inhabitants of thefe pla. ces refembling each other in colour, features,and thape, and who, before foms of them acquired a knrwledge of the arts and fciences, might hare likewife refembled each other in their manners, cultoms, religion, and Janguage

The only difference between the Chinefe nation and the l'artars lies in the cultivated fate of the one, and

the unpol become a ed into re in tents, fixed abo two natic hereditar nefe $\mathbf{E m}$ were not fo numer dominion

It is ve toms of $t$ Tartars ; eta, and ed to a ce the -Tarta of the noi country, iz tioned an At differe and the ce and from 10 all thes ireen fo:

It appe tween the ricular cu leaving or This mod rian Empi and confer in ufe amc nefe, the A Many dians, whi ly in their call a Aay whofelan European: Ihe form 
reach as ximity to ints from

eto draw, ig on this in the po. indations, aatowe are

it Ahould crols the ze. of the e. want of maritime lihomable is liower. cridental. ingers of rly winds e retained m whence fit by the 0 appears igrations, ent parts,

hiries, and at inmer. h eal, by and from at differ. tary, Chi. thefe pla. ind thape, nrwlejge refembled gion, and

tion and one, and
Whe unpolithed fituation of others The furmer have become a commercial people, and dwell in houfes form. ed into regular towns and cities : the latter live chiefly in tents, and rove abuut in different hordes wi:hout any. fixed ubode. Nor can the long and bloody wars thefe two nations have been engaged to, exterminate their hereditary fimilitude the prefent family of Chinefe Emperors is of Tartarian extraction; and if they were not fenfible of fome claim betide that of conquelt, fo numerous a people would fearcely lit quiet under the dominion of itrangers.

It is very evident that fome of the manners and cuftoms of the American Indians refemble thofe of the Tartars : and I make no doubs but that in some future era, and this not a very far diftant one, it will be reduced to a certainty, that during fome of the wars between the-Tartars and the Chinefe, a part of the inhobitants of the northern provinces were driven $f_{1}$ om their native country, and toot refuge in fome of the ifles before men. tioned and from thence found their wap into America. At different periods each nation might prove vietorious. and the conquered by curns ty tefore their conquerors; and from hence might arife the fimilitude of the Indians to all thefe penple. and that animolity which exilts beiween fo many of their tribes.

It appears plainly to ve that a great-finitarity be. tween the Indians and Chicefe is confpicusus in that par. ricular cuftom of Thaving or plucking off the hair, and: leaving only a fmall tutt on the crown of the head. This mode is faid to have been enjnined by the I'arta. rian Emperors on their acceflion to the throne of China, and confequently is a farther proof that this cuifom was in ufe zmong the l'artars, to whnn as well as the Chinefe, the Americans might be indebted for it.

Many words alfo are ufed bonth by the Chinele and Indians, which have a refemblance is each other not on. If in their found, but their ingnification. I be Crinele call a Aave, thungo, and the Naudowefie Indians, whofe language from their little intercourfe with the Europeans, is the lealt corrupted, term a dog, thungulh. Ihe former denominate one fpecies of their tea, thou 2 
Iony ; the latter call their tobacco. froufaflau, Many other words ufed by the Indians contain the fyllables che, chaw, and chew, after the dialeet of the Chinefe.

There probably might be found a fimilar connection between the language of the Tartars and the American Aborigines, were we as well acquainted with it as we are, from our commercial intercourfe, with that of the Chinge.

I am confirmed in thefe cunjectures, by the account of Kamfchatka, publifhed a few years ago by order of the Emprefs of Ruflia. The anthor of which fays, that the lea which divides that peninfula from America is full of iflands, arid that the difance between Tfchukotiki. Nofs a promontory which lies at the eaftern extremity of that country, and the chaft of A mertica is not more than two detgroes and 2 haif of a great circle. $H e^{\text {further }}$ fays, that there is the greatelt reafon to fuppofe that $A$. fia and A merica once joined at this place, as the coafts of both continents appear to have been broken into capes and bays, which anfwer each other: more efpe. cially as the inhabitants of this part of both refemble each other in their perfons, habits cuRoms and food. Their language, indeed. lie nbferves, does not appear to be the fame, buitheh the inhabitants of each dittriat in Kamfchatka fpeck a language as different from each other, as from that fpoken on the oppotite coalt. Thefe obfervations, 10 which he adds, the fimilatity of the boats of the inhabitants of each coaft,and a remark that the natives of this part of America are wholly Arangers to wire and tobacco, which he looks upon as a proof that they have as yet had no communicatien with the na? tives of Lurope, he fays, amount to little lefs than a demonftration that America was peopled from this part of Afin.

The limits of $m y$ prefent undertaking will not permit me id diell any longer on this fubjec, or to enumerate any other proofe in favor of my hy pothefis. I am, how. ever, fo thuroughly convinced of the certainty of it, and fo defiroins have I been to obtain every teltimony which can be procured in its fupport that I once made an offer to a private Yociety of gentlemen, who were cu.

rious in cated $\mathrm{mj}$ take a jo fit; throl to the int England both on 1 whom I the doctri curiofity polativiras private fu I ato b clufións: of that le with him nature, is bate tras not indif them a $\mathrm{g}$ ? tions of $t b$ another $q$

One of Behring a about tise pears to $c$ conclufior Phaped t? land, whic can contir feems to welt coalt with the ir North Ap Calumet o thip unive and an ufe Ohe of fupport 0 judgrnent, Gás, ar ive 
uv, Many

f) llables hinefe.

onnection Aimerican it as we at of the

accounts order of fays, that rrica is full chukotiki. tremity of more than le further fe that $A$. the coafts oken into nore efpe. 1 réemble and food. iot appear ch diftriâ from each i. Thefe ty of the mark that Atrangers s a proof ith the na: is than 2 this part

not permit snứmèrate ram, how. inty of it, teflimiony rice made 6 there cul. rous in fuch refearches, and to whom I had communicated $m$ f fentiments on this point, that 1 would under. take a journey, on receiving fuch fupplies as were need. falt through the north eaft parts of Europe and Afia to the interios parts of America, and from thence to England, making as I proceeded, fuch obfervations both on the languages and manriers of the people with whom I thould be converfant, as might tend to illuftrate the doctrine I have here laid down, and to fatisfy the curiofity of the learned and inquifitive : but as this pro. polat was judged rather to require a national than a private fupport; it was not carried into execution.

$I$ ats happy to find fince $I$ - formed the foregoing conclufions, that they correfpond with the fentiments of that learned hiftorian, Doctor Robertfon s and tho" with him, I acknowledge tliat the invelligation, from its nature, is fo obfcure and intricate, that the conjectures I bave roade can only be confidered as conjectures, and not indifputable conclufions, yet they carrv with them a greater degree of probability than the fuppofitions of thofe who affert this continent was peopled from another quarter.

One of the Doctor's quotations from the journals of Behring and 'I'chirikow, who failed from Kamfchatkar about the year 17,41, in queit of the New World, ap. pears to carry great weight with it, and to afford our conclufions firm fupport: "thefe, commanders having thaped their courfe towards the ealt, difcovered iand, which to them appeared ts be part of the American continent; and according to their obfervations, it feems to be fituated within a few degrees of the north welt coalt of California they had there fome intercourfe with the inhabitants, who leemed to them to refemble the North Americans; as they prefented to the Rulfians the Calumet or Pipe of Peace, which is a fy.mbol of friendthip univerfal among the people of North America, and an whage of arbitrary inttitusion peculiar to them."

Ohe of this incomparabie writer's own arguments in fupport of his hypothefis is alfo urged with great judgment, and appears to be nearly conclufive. He Gays, "s we may iay it down as a certain principle in this 
eaquiry, that America was not peopled by any natiox of the ancient continent, which had made confiderable progrefs in civilization. The inhabitants of the New World were in a tate of fociety fo extremely rude, as is be unacquainted with thafe arts which are the firlt ellays of human ingenuity iu its advance, towards im. provement Even the moll cultiyated nations of $A$. merica were Atrangers to many of thafe fimple inven. tions, which yere almolt coeval, with fociety in othor parts of the worid, and wera known in the earlief peri. ods of civililife. From this it is manifeit that the tribes which originally migrated to America, came of from nations which mult have been no lefs barbarous than their polterity, at the time when they were thit difcor. ered by the Europeans. If ever the ufe of iron had been known to the Gaves of A merica, or to their pro. genitors, if ever theyltiad employed a plough, a lowm, or a forge, the utility of thefe inventions would have pre. ferved then, and it is impoffible that they hould have bein ubandoned or forgorten."

\section{CHAPTER II. \\ COF THEIR PERSONS, DRFSE, ÉE.}

F

ROM the firt fettlement of the Freach in Cariada to the conquet of it by the Englith in 1760 , feveral of that nation, who had travelled into the interior parts of North America, either to trade with the Indians; or to endeavor to make converts of them, have publifhed accounts of their cuftoms, manners, \&e.

The privicipal of thefe are father Louis Hennipen, Monf. Charlevoix, and the Baron Le Hontan the Grit, many years ago, publithed fome very judicious re. marks, which he was the better enabled to do by the afe Gifance he received from the maps and diaries of the onfortunate M Dio la Salle, who was aflaftinated whila

he was on gentlemar hand, he? ing parti retpects hi mas in his mong the obferved)e gence he l'be acs thofe of C icisl parts, mere delu Some 0 thefe parts few, if an Englifh Iai chitted by i would hav they have. gious pritu their conve Since th trymen wh their langu ever a; the terior pitrts iire nations of the genv ners of the them.

The fout Alant interc have prefer original pu vices with 1 and the frei the baneful ropeans, ba acters.

In fuch: 
be was on his travels; by fome of his own party. That gentleman's journals falling into father Hennipien's hand, he was enabled by them to publith many interes: ing particuiars relative to the Indians. But in fome relpects he fell very fliptr of that knowledge which it was in his power to have attained from his long refi dence anong them. Nor was he always (as has been already obferved) lexat in his calculations, or jult in the intelligence he has given us.

I'be accounts pyblithed by the other two, particularly thofe of Charlenoix, are very erroneous in the geograph. ietil parts, and many of the ftories told by the Baron are: mere delufions.

Some of the Jefuits, who heretofore travelled into thefe parts, have alfo written on this fubject ; but as few, if any, of their works have heen tranflated into the Englifh language, the generality of readers are not benclitted by them $;$ and, indeed, had this been done they would have reaped but feve advantages from them, as. they have chiefly confined their obfer vations to the religiolis priticiples of the lavages, and the fteps taken for: their converfion

Since the conquelt of Canada, fome of our own countrymen who have lixed among the Indians; and learned their language, have publifhed their oblervations; how. ever a; their travels have not extended to any ot the inturior purts I treat of, but have only been mide among (ii) nations that border on our fettlements, a nnowledge of the genuine and uncontaminated cuftoms and man. ners of the' Indians could not have been acquired by them.

o Catiadar feveral of rior parts nidians, or publifhed

Hennipen; an. I the dicious re. by the af: ies of the ted whill

The fouthern tribes, and liofe that have held a conflant intercourfe with the French or Englifh, cannot have preferved their manners or their cuttoms in theit original purity. They could not avoid acquiring the vices with the language of thafe the converfed with; and the frequent intoxications they experienced through the banteful juices, intruduced among them by the $\mathrm{Bu}$ ropeans, have completed a total alteration in their charaders.

In fuch as thefe, a confufedly medley of principles 
or ufages are only to be obferved; their real and unpo. luted cuftom, could be feetr among thofe nations alone that have held but little communication with the prov. inces. Ithefe $I$ found in the worthwelt parts, and there. fore flatter my felf that $1 \mathrm{am}$ able to giva a more jult accoune of the cultoms and manners of the Ihdians, in their ancient purity, than any that has been hitherto publifhed: I have made obfervatinns on thirty, nations, and though moll of thefe have differed in their langua. ges, there has appeared a great fimilarity in their man. ners, and from thefe I have endeavored to eztract the following remarks.

As I do not propofe to give a regular and connected fyftem of Indian concerns, but only to relate fuch par. ticulars of their maniners, cultoms, \&c. as I thuught molf worthy of notice, and which interfere as little as poff. ble with the accounts given by other writers, I muft beg my readers to excufe their not being arranged fy flemat. icalty, or treated of in a more copious manner.

The Indian nations do not appear to me to differ fo widely in their make, color, or conftitution from éach other, as reprefented by fome writers. 'They are in generd tlight made, rather tall and Atraight, and you Seldom fee any among them deformed, their Ain is of a reddifh or copper color : their ejes are large und black, and their hair of the fame hue, but very rarely is it curl. ed. they have good teeth, and their breath is as fweet as the air they draw in ; their cheek bones rather raifed, but more fo in the women than the men; and the for mer are not quite fo tall as the European women, how. ever you frequently meet with good faces and agreea ble perfonstamong them, although they are more in clined to be fat than the other fex.

I thall not enter into a particular enquiry whethes the Indians are indebted to nature, art or the tempera. ture of the climate for the color of their Akin, nor thall I quote any of the contradictory accounts I have read of this fuhieft I I fall only fay, that it appears to the to be the tineture they received originally froms the hands of their Creator but at what period the variation which is at prefent vifible, both in the complexion and feat 
and unpo. tions alone the prov. and there more jult Ltudians, in n hitherto ty, nations, eir langua. their man. extraes the

1 connected e fuch par. ought mol the as polfi. I muit beg id fy.femal. er.

to differ fo from each hey are in bt, and you Asin is of a and black, $y$ is it curl. is as fweet ther raifed, ind the for. men, how. ind agreea. e more in.

ry whether e tempera. 1. nor thall have read ears to time s.the hands ation which and fear.
Wh of many nations took place. at what time the Eu. rgean whitenefs, the jetty hue of the Ifrican, or the opper caft of the Anericain were given them; which - the original color of the fir it inliabitants of the earth, which inight be efteemed the moft perfect, I will not tend to determine.

Many writers have afferted, that the Indians, even at Ceithaijureft period of their exiftence, are only furniftswith hair on their heads, and that notwithftanding te profufion with whicn that part is covered, thole nts which among the inhabitants of other climates to ofually the feat of this excrefcence, remain evitirely tret from it.' Even Dr. Robertfon, through their mifo prefentations, has contributed to propagate the error; ind fuppoling the remark julty founded, has drawi averal conclufions from it relative to the habit and temperature of their bodies, which are confequently invaid But from minute enquiries, and a curious infpeclion, I im able to declare (however refpectable I may wild the auchority of thefe hiftorians in other poirts) hat their affertions are erroneous, and proceeding from hie want of a thorough knowledge of the cuftoins of the Indians.

After the age of puberty, their bodies, in their nat. tral thate, yre covered in the fame misner as trofe of the Europeans. The men, indeed, elieem a beard very anbecoraing, and take great pains to get rid of it, nor sthere ever any, to be perceitad on their faces, except then they grow old and become inatrentive to their ap. pearauce Every crinou etflarefcence on the c:ther parts If the borig is bild unformly by them, and both feres mploy much time in their extirpation:

The Handowefres and the renote so ito flack hem ont with bent pieces of hard wond, firged into a and of nippers selifet th ofe who have conmunication with Europans preave fiom them wire, which they wit irto a fcrew of sorm; applying this to the part, hey prels the riags wogether, and visth a fudden twitch Haw out all the hairs that are inciofed between them. The nen of exen nation siffer in their drefs very litte from each other, excaps: thofe wiko trade with tbe 
Europeans; thefe exchange their furs for blankets, thirts, and other apparel, which they wear 25 much for orna. ment as necetity. The latter fatten by a girdle around their wails abuut half a yard of broadcloth, which covers the middle purts of their bodies. Thofe who vieur thirts never make them falt either at the writ or collar; this would be a molt infufferable confinement to them They throw their blanket loofe upon their Moulders, and holding slie upper fide of it by the two corners, with a knife in one hand, and a tobacco pouch, pipe \&c, in the other: thus accnutred thes walk a. bout in their villages or camps : but in their dances they fldom wear this covering.

Thofe among the men who with to appeas gayes than the ref, pluck from their heads all the hair, except from a fpot on the top of it. about the fize of a crown piece, where it is permitted to grow to a confiderable length: on this are faftened plumes of feathers of various colore, with filver or irory quills. The manner of cutting and ornamenting this part of the head diftin. guithes different nations from each other.

They paint their faces red and black, which they ef. teem us greatly. ornamental. " They allo paint them. Clves when they go to war; but the method the j make uf of on this necafion differs from that wherein they uf it merely as decoration.

The joung Indians, who are defirous of excelling their companions in finery; thit the outward rim of both their ears; at the fame time they take eare not to fepa. rate them entirely, but leave the fieh thus cul, Aill un. touched at both the extremities, around this fpongy fubfance, from the upper to the lower part; they twilt brals wire, till the weight draws the amputated rim in a bns of five or fix inches diameter, and drags it almoft down : to the Thoulder. 2 his decuration is efterhed to be cxict. fively gay and becoming:

It is alfo a common cuftom among them to bote their nofes, and wear in them pendants of differen: forts. I obferved that fea thells were much worn by thofe of the interior parts, and reckoned very ornamen. tal; but how they procure them I could not leasn;

mobably Ex.

They: 8 that befo doth hail ifort of itued as 10. dinit , the itulf $c$ lothe tea haed, an the leg,is 8 curtimanic binds or i pine quill: mong the deal of fric than any "Itheit A or buffalo ding to th rematuing as to be c The'edges of brats" o lich tong, full tinklin The wo from the the Europ iffed by th ticoat:

alind of not the ar. er or cloth their leg. thented as They d their hedad find wo rh 
kets, thirts for orna: the around th, which Thofe who ie wrift or onfinement apon their the turo ceo pouch, os walk a. lances they

reas gayes 1air, except f a crown onfiderable ers of varimanner of ead diftin.

th they ef. aint them. they make lerein they

excelling im of both 10t to fepa. it, Atill un. pongy fub. twilt brais $\mathrm{a}$. in 2 bne molt dovin a be catel.

$n$ to bote different worn by - crnamen. not learn; rrobably by their traffic with other nations nearer the (3)?

They 80 without any covering for the thigh, except that before fpoken of, round the midale which reaches do $n$ balf way the thighs ; but they make for their legs Cort of ftucking either of thins or cloth; thefe are. itwed as near to the thape of the leg as poffible, fo. as 10 adtinit of being drann on and off the edges of the tuff of which they are compoled are left aunexed to the feam, and hang loofe for about the breadth of $a$ laed and this part which is placed on the outflde of the leg, is generally ornamented by thofe who have any cuthmunication with Europeans, if bf cloth with rit. fands r lace, if of leather, with embroidery and porcus pine quills curioufly colored. Strangers who liug os mong the Indians, in the parts where there is $a$ gteat deal of friow, find thefe Pockings much more cortvenient than any others.

Theit thoes are made of the Akin of the deer, ell. or buffaloe s thefe, after being fonetimes drefted accor. ding to the European manner, at others with the. hait remaining on them, are cut into thoes, and fathoned 10 as to be cafy to the feet, and convenient for walking. The'edges round the ancle are decofated with piec of brats or tib fixed around leather Atrings about fich tong, whien being placed rery thick, make th ch full tinkling noife, either when tliey, walk ur dance.

The womea wear a covering of fomie kind ot ot from the neck to the knees. Thole who trade with the European wear a linen garment, the farie is that tifed by tre met, the flaps of which thang over the pet. ticoat. Such as dress after theil ancient manner, matie athind of Mift trith leather, which covers the body but not the urins. I heir petrictonts are made either of leath. er of cloth, and reach frote the wailt to the knes. $\mathrm{O}_{\mathrm{B}}$ their legg they wear ltoskings and thoos, mide and ornas. thented as thof of the trean.

They differ frof ejch othet in the mode of arefing their heads each following the cuftom of the nation had to which ibet belong, ond adhefin to the forra 
mado ofe of by their ancoftors from time immema tial.

I remarked that moft of the females, who dwell on the ealt fide of the Miffifippi, decorate their beads by encloling their hair in ribbinds, or in plates of filver the lattet is only made ufe of by the higher ranks, as it if a colf $y$ ornament. The filver ther ufe on this occafion is formed into thin plates of about four inches broad. in feveral of which they cunfine their hair. That plat which is nearelt the head is of a confiderable wiath, the neat nisrower and made fo as ropals a little way under the other, and gtadually tapering, detcerd- to the waift The baix of the ladian wotnen being i general very long, this proves an expenlive method.

But the vomen that live to the wett of the Mitifip pi, viz. the Nandowefles, the Affinipoils, 3xc. divide their hair in the middle of the head, and form it into two tolls, one againft ench ear. There rolls are about three inches Jong, and as large as their writts The hoog in a perpendicular attutude at the front of each ear, and defcend as far as the lowet part of it.

The women of every nation geaerally place a fpot of mint about the fize of croitn piece, againit each 1 Come of them pat paint on their hair, and f petimes a finall fpot in the ruiddle of the fore $\therefore$ d.

The Indians, in general, pay a greater attention to thir drefs, and to the ornaments with which they decos rate their perfons, than to the accommodation of theil huts or tents. They conftruet the liter in the follow ing frimple and expeditious manner.

Being provided with poles of a proper length, they falten two of them acrofs, neas the ends, with baridi made of bark. Having done thin they raire them up and extend the botrom of cach as wide es they propises (i) make the area of the tent 8 they then erect others of un equal teight, and fis them to as to fupport the ivo crincipal onet. On the whole they $l+5$ the Isins of the elle or dser, fewed together, in quatity tulifieng to cover the poles, and by lapping over to form the chor. al gruat number of Akins are fometimes regraired

for thi cious.

vas at bodion

The

they ed venithe

Thy

inent

artge topt as Tho) ing thet then lat ande 0 pots. The? tere is toofs th this is: riolent? come.

The we plac not larg commo bout for younge Asith domefti formati fo ant's io form but the is tod of rueb The their vi ar jou woll tis 
se immema

tho dwell on

sir beads by es of liliver: ranks, as it if this occafion hes broad it

That plate rable width; s a little way delcend- 10 ien being it method.

the Mififipo divide their it into two - are about rsifts. They ront of each tt of it. ace a f pot of gainf each - hair, and of the fore.

attention to th they decos ion of theit the follow:

ength, they with baridi C. them up e) propise a others of bit the ino he Rins of Y. futficienf form the se required for this purpote, as forme of their tents are verz capa. givas That of the chief warrior of the Nandowefliet ras at leifl forty feet in circumference, and very comodious.

They obferve no regularity in fixing their tents whet they encampo but place them juit as it suits their con. waiener.

This huts alio, which thofe who ufe not cents, ored When they travel, for very feor tribes bave fited abncies, or roguhar towne, or villages, are equalty fimple, ard ai. iof as foon conftrulted.

They fie fmall pliable poles in the groust, and bend. ing then till the meet at the top and form a femil circles then laif thom rogechet. Thore the cover wilh mats ande of suthes platted of with birch bark, which Wey carry with them in thicir canoes for this pur. pose.

Thefe eablns have neither chimnies nor riadows; there is only a fmall aperture left in the middle of the rofs through - wich the finoke is dicktiarged, but as this is obliged to be topped when it sains or fnows violently, the fmoke then proves excedingly trouble. fome.

Ther lie on Rkins, generally thofe of the bear, whic" are placed in rows on the ground is and if the floor is not large enough to contain beds fufficient for the fo. commodatiun of the whole family, a frame is erefled a. bout four or five feet from the ground in which the younger part of it deeps

Af the habieations of the Indians are thus rude, their domettic utenfils are fer in number, and plain in their formation. The cools wherewith they falion thern are fo artwrard and defentive, that it is not only impolisble is form them with any dogree of neatnefs or eletgance, but the time required in the exectition is fo confiderabley - to deter them from engaging in the manufaeturo of fuch as are not abfolutely necertary.

The Naudoweffies make the pots in which they bois their viaualis of the Black clas or ftone mentioned in ay journal s which refifs the ceicets of lise, nearly as well as iros. Whea ther roat, if it is a large joints of 
a whole animal, fuch as a beaver, they fir it as the Fill ropeans do, on a fpit made of mood, and placing the erids on two forked prop', now and then vurn it. If the piece is frialler they fuit it as before, and fxing the fpit in an esed pofition, with the meat inclining towards the fre, frequently change the lides till every part is fuficiently roulted.

They make their dibes in which they ferve up theit, meat, ane tleir bowls and pans, out of the knotty exa crefences of the maple tree or any other wood They fathion their poons with a tolerable degree of neatnef. (as thefe require much lefs trouble than large utenfils) from a wood that is termed, in A merica, Spoon Wood. and which greatly refembles box wood.

- Every tribe are now poffeffed of knives, and feels ta frike fire with. There being fo effentially needful for the common ufes of life, thofe who have not an in. mediate communication with the Eusppean traders,pur chafe them of fuch of their reighbors as are fituated. nearex the fettlements, and give in exchange for them faves.

\section{!}

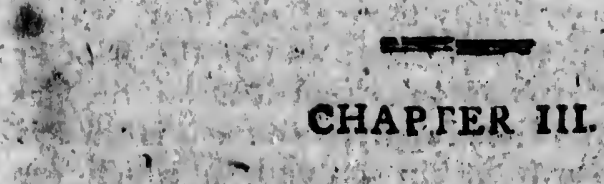

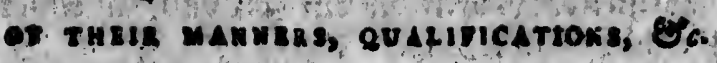

W

HEN the Indian tumen fit down, they plact themfelres in a decent attitude, with their knees clofe together but from being accoftumed to this polture, they walk badly, and appear to be lame.

They have oo midwives among them, their climate; or fome pecnliar happinefl in their conftitutions, render. ing any affltance at that time unneceftary. On. tliofe. occalions thas are confined but a fow hours from their ufual emplo, ments, which are commonly very laboti. ons, as the men, who are remarkably indolent, leave to them crees kind of drudgery 8 even ia their hunting.

pirties th gané bu eonfideral

The we born on' in morall back in on in fins. on fimall bent 'To the thing the trees at $\mathrm{h}$ they, trant the childr Len out, : are covere 1 Dort pe

The In dieir men more from Cer, \& c al they all w fume cult In ever proptiate. boch fing? with the $y$ ciety. ning Are mentis.

Ito holding as dowelfition. loferes ony ancefiny, the want ience. I pipellemen that the p bured fire 
as the Fith lacing the irn it. If tiexing the ag towards ry part is

e up theit, knotty ex. 2d. They if neatnefi. utenfils) son Wood. id Aeels ta. eedful for atot an int. aders, purs - fituared. for them

\%.

hey place nees clofe polture,

climate: 15, render. On thofe. rom their y laboli. int, leave $x$ bunting. purtes the former will not deign to bring home the game, but fend their wives for it, though it lies at a very confiderable diftance.

The women place their childien foon after they are born on boards liuffed with loft mors fuch as is found in morafea or meadowr. The child is laid on its back in one of this kind of cradles, and being wrapped in ftins or cloth to keep it warm, is fectired in it by fimall bent pieces of timber.

To thefe machines they faten Atrings, by which they. lang them to the braiches of trees; or if they find not trees at hand, falten them to a fump ot Tone, whilf they tranfact any needful buliners. In this pofiling are the children kept for fome months, when they are ta. Len out; the boys arefuffered to go naked and the girts are covered from the neck to the knees with a thitt and i Gort peticodt.

The Indian romea are remarkably desent during thir menitrual illnefs. Thofe nations that are molt reo more from the European fettlemenis, as the Nhudowef: fes, \&, c. are more partictularly attentive to this point i tho". they all without exception adhere in fome degree to the trone cuftom.

In trery camp or toint thete is at apartment ap. propriated for their retirement at this time, to which both fingle and married retreat, and feelude themfelves: with the utmolt Arietinefs during shis period from wl fu. ciety. Aftermarids they purify themfettes in run. ning Arcams and return to their different employ. ments.

The men an thefo occifions mol catefully aroid holding any communication with thetw, and the Nan. domelify art fo rigid in this obfervancesthat they will not

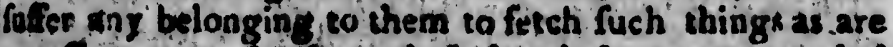
ateeflury, even tircifiom thefe fe male lunar retreats, tho" the want of them is attended with the utmoft inconven. ience. They are alfo So fuparfitious as to think, if a pipeflem cracks, which anong thom is made of woods thas the poffefitior bas either lighted it at one of thefe po. luted fret os bols form converte with a roman during

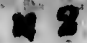


her retirement, which is efleemed by them molt difgrace. ful and wicked.

The Indians are extremely circumfpect and deliber. ate it every word and action $;$ there is nothing that hur. ries them into an intemperate warmet, but that inveter. acy to their enemies, which is rooted in overy Indian Veart, and never can be eradicated. In all other inftan. ots they are cobl, and remarkably cautious, taking care not to betray on any account whaterer their emotions. If an Indian bas difcovered that $\alpha$ friend is in danger cf being theercepted an 1 cut off by one to whom he has rendered himfelt obnoxious, he does not inform tim in plain and explicit terms of the danger he runs by pur. furing the track near which his enem y lies in wait for him, but he firt coolly ans him which way he is going that da) i and lidving reecived his anfwer, with the fame in. differeñre tells him that be has been informed that a dog Hes near the fpo, which might prohably do him a mifo chief. This hint proves fufficient, and liis frietrd avoids the danger with as much caution as if every defign and motion of his enemy had been pointed out to lim.

This apathy uften ftewrs itfelf on occegfions that would eal forth all the ferror of a fufceptible heart. If an Indian bas been ablent frott his family and friends many wouths, either on a war or houting party, when his wife and children theet bim at forme diftance from his habitation, infead of the uffectionate fenfations that would naturally arife tit the brealt of more refinged be. ings. and be productive of mutual congratulations, he continues his courfe without paying the leaft attention to thofe who furround bitn, till he arrives at his home.

He there fits down and with the Ame uncoucern as if he had not been ablent a day, fmoltes his pipe, thofe of his acquaintance who followed hing do the latme; and perhaps it is feveral hours before, he relates to them the incidents which have befallen him daring his ablerace, though perhaps he has left a futher brother, or fon on the field, whole lofs be oüght to have lamented, or has beta unfuecerfoul in the undertaking that balted him from bis home.

Has: ahale, or contiuute but or te immedi: fyomptom ger by w contente polure a perfealy This cuft elleetrin it vould men.

If 5.04 fignalized ny fealp. not ap pea ation ; makes te you itifor oners, he not fignif not how it

This fe from dite nolwithif: among 20 filial rend after allor tioned, th tion.

Anothe paying th lar peribo incended: to the oth conse neat the conves atin goes 
A difgrace.

id deliber. 3 that hur. at inveter. ry Indian her inftanaking care etriotions. in danger om he has orm tim in ns by par. it for him, going that le fame in. that a dog him a mifo end a voids cíy defign d out to

that would rt. if an onds many when his from his itoons that Atined be. tions, be attention his home. ovicervias pe; thofe the lame; 3 to them is ablence, - fon on d, or has thed him
Has an Indian been engaged for fereral days in the thafe, or any otber laborious expedítion, and by accident continued thus long without food, when he arrives at the but or teit of a friend where he knows his wants may be immediately fupplied, he takes care not to fhow the leaft fronptoris of impatinces or to betray the extreme hunger by which he is tortured, but on being invited in, fit contentedly down, and fmokes his pipe withrs much comb polure as if erery appetite was allayed, and he was perfecly at eafe; the does the fame if among Arangers. This cuftom is Atrially adhered to by every triber as they elledn it a proof of fortitude, and think the reverfo would entitie them to the appelation of old wo men.

If you tell an Indian that hís children haye greatly. fignalized themfel ves againt an enemy, have taken mas ny foalps, and brought home many prifoners, be doey not appeat to feel any extraordinary pleafure on this oto anfion, his affwer generally is "it is well, and the makes very little enquiry adoutit. On the contrary, if you idform him that his children are flain or taken prif

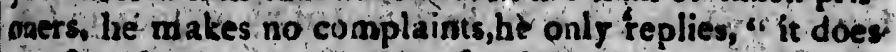
not fignify ;" and probably, for foune time atteant, aft; not how it happened.

This feeming thidfference, however, does not proceed from dit eritice fuppretifon of the natural affections if for notwithflanding they are eflecmed ravages, I never fint among ant other people greater pronfs of parental or filial iendervefs, and ulthough they meet their wivion after a long abfence with the tocial indifference jula menis tioned, the $\mathrm{y}$ are not, in general, void of conjugal affer. tion,

Another pecaliarity is obfervable in their manner of paying their vilits if an Indian goes to vilit a partiction lar perion in th fumily, he mentions to whom lar vist is. intended, and the ter of the family immediately resting to the othet end of the but or tent, are careful not to conse ntar enough to interrupt them during the whole of the converfation. "The faime method is parfued if a: wat goes to pay his refpets to one of the olter fezs 
but then bo munt ba carefnl not to let lore borthe fubjed

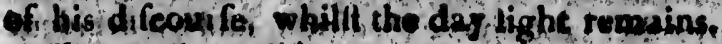

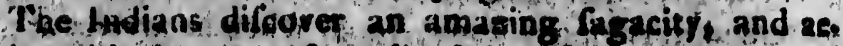
ouire with tho gredtef readiuefs any thing that depende

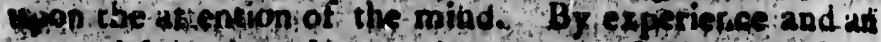
aeute abferwation tho attain many perfections to which the turopono ara lrangers. Hor initance thes will crplo a ford or a plan which in two hondred miles in breadus und reweh with great exactpers the point at Which they jacended to arriks, keping dnring the whole afthis fpows in a direa lipe, without any upartial devia

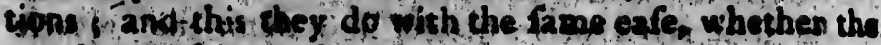
wonthor be fair or clouds.

With equal acutenels will thet point to that part of the heapens tho fun is in, thosgl it be intercepted by clonds of foge Fefdo this they are abie to purtua

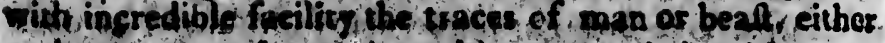

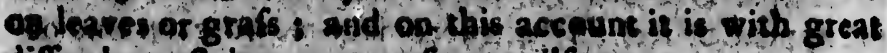
difenler a cyins enomy ersapes difcolery.

Thes are ind beted fon tive talents not only to nature, byt to in extruordinary sommand of the intellectual

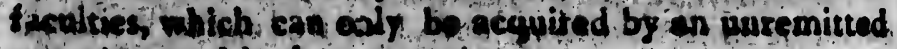
atrintiper and la lone exparienes.

Ther are in general tery bappy in a resplite mem.

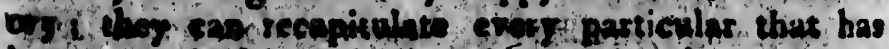

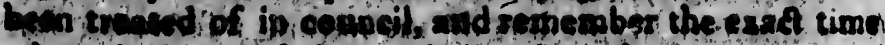

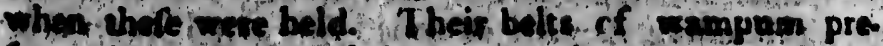
Sesme tha fablangs of the treatios thas heve copeluded with tha mighthering cribes for ages tacts to which

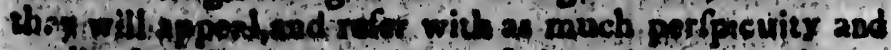

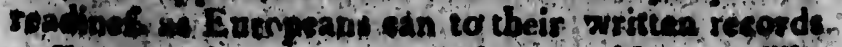

Every nation pare great refpee to old age. The ad

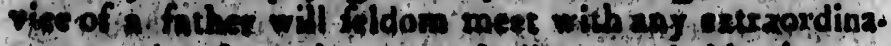

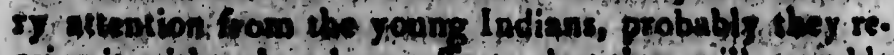

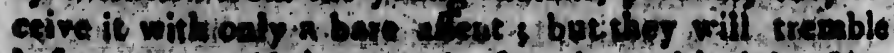

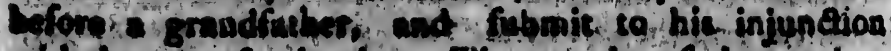

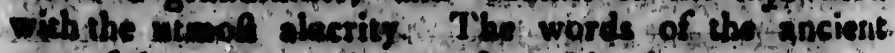

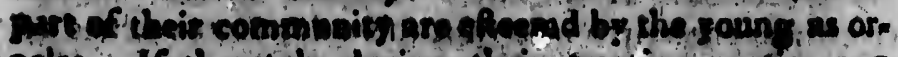

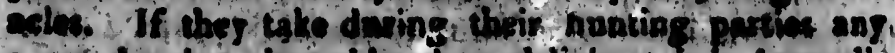

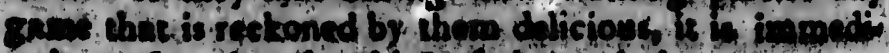

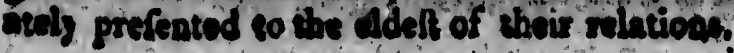

They with care cotiteriton jill rutio listie tró or take a ins thes? eftinábilo

Gatrin to fiblices' ing, that When 2 oppole an ate alert atuity, 0 oftiles The in Eroper. and otren thing they do tot fol for they - o efcapes th a phitoph Nhe $\mathrm{g}$ dípótíán inth ter dith are th warithey fim in w rorit ené thols wo - 13 e Itic polóf $y^{\prime}$ his vifes. thoton s $^{2}$ rifers itte thite oftet

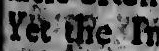
getnpertat Montivite 
ze fubjea

and ase depende andiat to which. Ley will miles in point at the whole rial devia acthen the

at part of eepted by to purtuc an either. vidh great

tonature, atelleciual aremitted.

ise mem. thint has riae timo

pup pres Sopeluded o which virity and sordan

The ad. racordina. ither re. trémble niuncion ancierse. ny or or. The ans ixomaty
They never fuffer themfelies to be overburdened with care, but live in a tated of perfee tranquility and cotiteritment beifg naturall adolent, if provifiod filf fufficient fof their fubliftence chn be procured with thite trouble, and rear at hand the 2 will not go far. or take any ertráordinary pains for it though $b /$ fo doWother uight tequire greate plenty, ans of a thore etimábleting

Hating much Teifure tibe the indalge thisindalence to Which the t are $\mathrm{ro}$ prones of eating, drinking or leep ing, and rambling about in their town or c5mpo But When necellity obliges the to take the field wither to oppole an enemy, ar to procure themlelve food, thes dite alert and indefatigable, Why inttance of their idvity, on thef occalons tril te giren when I treat oftheif ivars:

The infatuating fpirit of goming b hot confined to Etropes the Pojans alro fel the bewitching impulf tid often lonfe their arads, thet apparel, ond evers thing they are poffeffed of 1 in this cale, howeter, thes do tot follow the example of more refined gameltera; for thay neither murmef not fepine f not fretful word efcapes them, but the bear the owns of fortune with aptrito fophic compofuref

The greateft blemith in their chardact is that favd difoticion which inpels them to treat their enemios Wh a ferenity etty other nation fhudder at' 5 are this barthirous to thole with whom they ate at warthey are friendly, hofpitable, and hunda in pease It miy's with truth be faid of chem litit the are tho corft enemies, and the beft friends, of an y people in the Whaln world

- The Iridians in general are Atangers to the paffion of palow fy and brand a man with folly that is difruitutul of his the. Anong forie bands the very idea is not lhown f as the moit abaidoned of their young uneh very rivery tiempe the virtwe of tharried women, nor do Ahe oftet port themfelves in the way of rolicitation

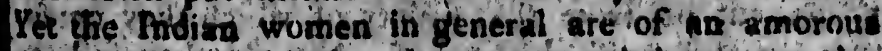
Complatare, did before they are married are not lie

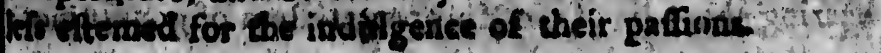


The, Indiups in their common. Aus, are Arangers of all diftinatipn of eronarty essept in the articles of do

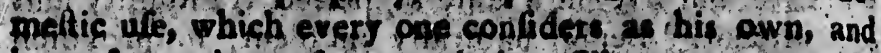
increales os circumlonces admis the are extremely

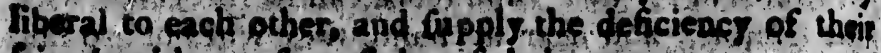
friends with ony fuperfinisy of their onp.

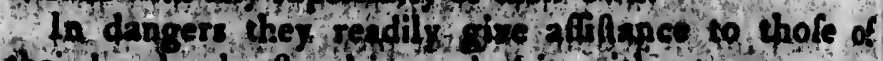
their band, who fand if need of it mithour ons expec

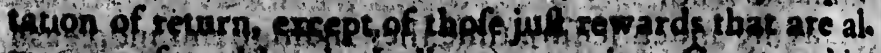
Warc conferm oby the Inding on meris. Governed by

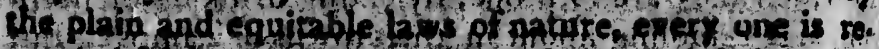

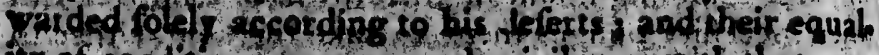

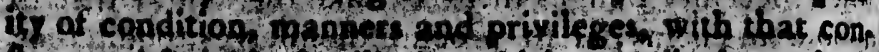

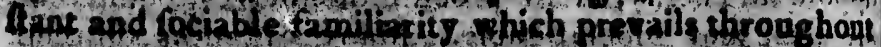

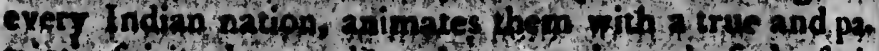
triotic fpirit, that tend to the general good of the foch Ot 9 which the thoth

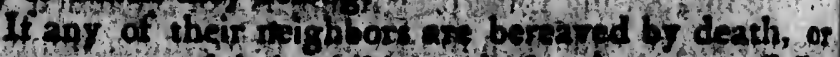
by an enemy of their chidren, thot who are poffeffed

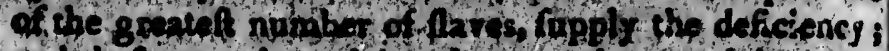
and thefe ane adopted b them and honed in evert

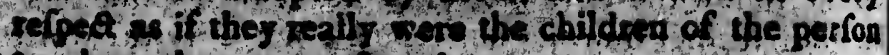
ta whow that wh or ing

The Indians, exegp thofe who line djoining to the

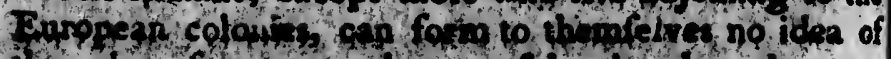

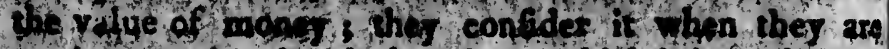
made acguaint d wish the ules ta which it is ap plied by

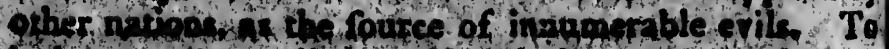
it of st sibut ot tha milchiof that are prevalent a.

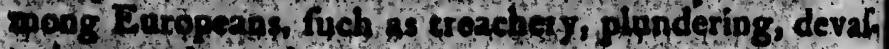
thich an purder.

The efferm it irrational that one wan thould be pof Grod of oteater quhntity than anowhes and are amaz. Id that ali henor flould be annexed to the poffefiog

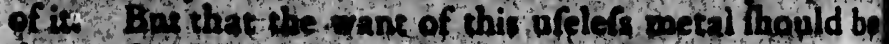
the cans of depriving perfone of their liberty and the - aecount of this partiol diftribution of A 352 num

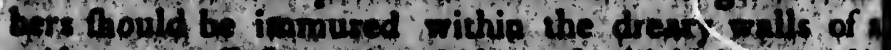

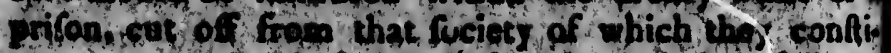

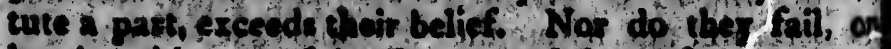

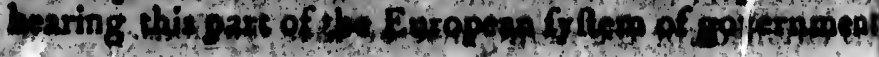

thitis

oNSI] the is very The inter Wlictiond the $e^{2}$ Some nat 100us, and Wur mont to add ! moon: Tagreat on the detiting th Whity ind 


\section{taketes reavets.}

angers to les of do awn, and extremels 7 of that

e thole of ins expeso but are al. veraned by une is ro. Geir equal ithas conp hrovighou is and par If the foch

deach, of - potefted toficiency: 1in ever: the porfon

sine to the no liche of a they are applied by vile $T O$ eralent a. log, devah

ild be polf are ama2. poffefinos i thopld bo sond then $35+1$ num Dallo of n) coalti Fivi of Whothes?

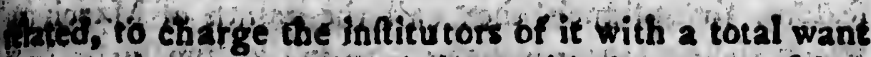

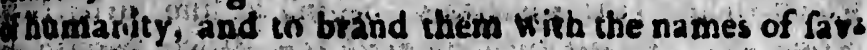
ces rad hrutes.

They thew atho of an etual degree of indifference for Whoductions of att. When any bt thefe are thewn tem, they fay, of th is pretty, I like to look at it, bit Went tiquititive about the conltruation of it; nether Whet forth proper conceptions of its ufe But if teit them of a perfon who is able to ruth thith great illity that is well silled tn Kunting can dired with wing, dith a gun, or berid with eate a bot, that can destroulf work a catho, tunderftatids the art of war, is squanced with the thation of a country and can Whe his way without a guide, through an indthethe fors foblthng dating ethe on a funtl quantity of protif

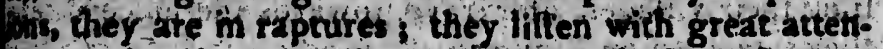
on to the pleafing tate, and butrow the hiphes chins ond ditus ob ulle hero of it.

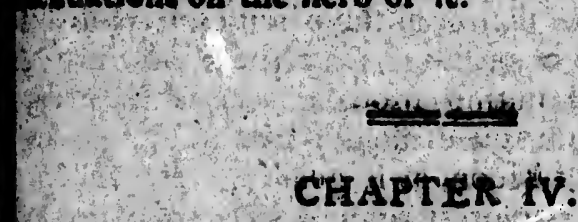

TÁEIR wRTHOD or RICrovina rimt, \&d.

ONSIDERING their ignorance of attrotolthy the is very rationally ditipled by the Htiens. Tlios Wie interior paites (atd of thote 1 would gendrally be

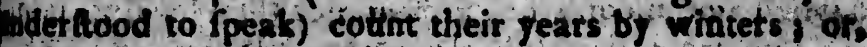

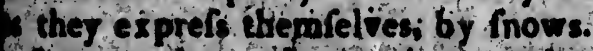

Some netions dhoth theth reckon thel seats bs Wous, and thake chem comilt of tretive fynodict of hat montlis, obferving, wheh thirty monns have wath

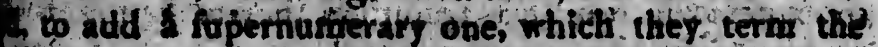
moon $s$ and then begin to count as before. They orgreatroterd to the firt appearance of every moon;

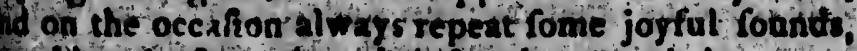
teting the folte tine their hands tovards it.

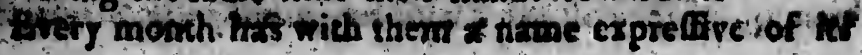


Keafon; for inftance, the $x$ call the month of March (th - bich their year generally begins at the firf New Moon after the vernal Equinor) the Worm Month of Moon, bécaule at this time the worms quit their retreats in the bark of the trees, wood, \&c, where they have Deltered themfel ves during the winter.

1 The month of d prii is termed by them the month of Planis. Nay, he month of Flowers June the tiot Moon July the Buck Moon. Their reafons for the denowinating thefe is obvious.

Auguit, the sturgeon Moon : becaufe in this month they catch great numbers of that fith

September, the Cotu Moon ; becaufe in that month they gather in their Indian corn

October, the Travelling Moon as they leave at this time their villages and travel towerds the place where they intend to hunt during the winter.

November, the Heaves Moon; for in this month the beavers begia to take thelter in their houles, having laid up a fufficient Aore of provifions for the winter leaion.

December, the Hunting Moon, becaufe they emploj this month in purfuit of theit game

January, the Cold Moon, as it geverally freezes har det, and the cold is more intenfe in this than in an' other month:

February, they call the Snow Moon, becaufe more fnow commonly falls during this nonth, than ong oth. ex in the wituter.

When the moon does not hine they fay the morn is dead and fome call the three lat days of if lle naked days. The moon's firt appearance they torm its cum. Ing to life again.

They make no divition bf weeks ; but days they count by feeps, half days by pointing to the fun at noond and fuarters by the rifing and the fetring of the fun: ta exprers which in their traditions they make ule of ve. xy fignificant hierogly phics.

The Indians are totally urmblled in geography as rell us al, the other fciences, and $y$ et, as 1 liave before hinted they draw on their hisch bark rery exact clart Us maps of the countries with which th yare acquaino

14. The 1 Sentole Their dile to po hile their They r keagues, $b$ beet calc iwenty I halves ar their mar ics juft $\mathbf{x}$ war parti

They h are able ters appiea prehentior

During hhiéfs obf moou, in $d$ iley defir pening to the leaves 7rs. Af tions relat ten $\mathrm{Co}^{\circ}$ the drawn frr ithout $\mathbf{c}$ meded it. They fe $6 g 8 \mathrm{ged}$ th: doing I held the and jult ob tots of $t$ liem.

This he ins which, (urprite, th larily ove hon, afte 
March (th Girt New Month of ir retreats they have

month of the tiol as for this

his month

hat month

ave at this lace where

month the having laid nter leajon. they em.

freezes har zan in' an'" aufe morè fin any oth.

he moon is the naked mins cums

they count at noon of the fun: e ulo of ve.

graphy as - ave before xact cliatt acquainis is The latitude and longitude is only wanting to makePentolerably cómíplete.

Their fole knowledge in altronomy confifts in being Wle to point out the pole Rar 3 by which they regu. ihe their courfe when they travel in the night.

"They reckon the difiance of places not by miles or kagues, but by a days journey, which, according to the beft calculations I cocld make, appears to be about. twenty Englifh miles. Thefe they alro divide into hilues and quarters, and will demoniftrate thep. in their maps with great exainefs; by the the hierogl $\mathrm{ph}$. ics jult mentioned, when they regulate in council their par parties, or their moft difant hunting excurtions.

They have no idea of anthmetic, and thougt they are able to count to any, uumber, figures as well as letlers appear my flerous to them, and above their comprehenlion.

During my abode with the Naudoweffies, fome of the thiefs obferving one day a draft of an eclipfe of the moon, in a book of aftronomy which I held in my band, they defired I would permit them lo look at it. Hap. pening to give them the book fout, the began to count the leaves till they came to the place where the plate 725. After they had viewed it, and afked many ques. tion relative to it, 1 told them they, need not to have ta. ten fo much pains to tind the heaf on which it was dewn, fr I could rot ony tell in an infant the place, Without counting the leaves, bet alfo how many pre. needed it.

They feemed greatly amazed at $\mathrm{my}$ affertion, and begged that I would demonfirate to them the poffibility of doing it. To this purpore I defired the chief that theld the book, to open it at any particular place, and jult fowing the the page ca refilly to conceal the Hos of the leaves, fo that I might not be able to count them.

This he did with the greatel caution; notwithfland. ing which, by looking at the folio, I told him, to his great (urprite, the number of leaves. He counted them reg. Garly over, and difcovered that $I$ tras exact. And When, after tepeated trials, the Thitians found I could N 
do it with great readinels, and without ever erring th my calculation, they all feemed as much aftonithed ats if I had raifed the dead. The onily way they could aco count for no krowledge, was by concluding that the book was a fpirit, and whifpered me anfwers to whit. ever I demanded of it.

This circumftance, trifling as it might appear to thofe who are lefs illiterate, contributed to increafe $\mathrm{mr}$. confeguence, and to aug anent the favorable opinion they alretuly entertained ot me.

\section{CHAPTER $\nabla$.}

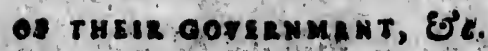

\section{H}

VERY feparate body of Indians is divided into bands or tribes; which band or tribe forms a litule com. munity with the nation to which it belongs. As the na. tion has fome particular fymbol by which it is dilind guithed from others, fo each tribe has a badge from which it is denominated s is that of the eagle, the pan ther, the tiger, ac. \&ic. One band of the Naudowetifes is reprefented by a snake, another a tortoife, a third a-fquir rel, a fourth a wolf, and a fifth a bufíalo. ITrough: out every uation ther particularice themfelves in the fame, manter, and the mednelt perfon among them wh renenber'his lineal defcent, and difinguith himfelt bf his refrestive family.

Did iog trary circumitances $t$ nd 16 confute the fup folition. Innulal be almof induced to conclide frox inis diltinction of tribes, and the particular attachment cf the Indians to them, that they derive their origin, at Itinc have afferted, from the Ifraelites.

Livides this, every ration difting uith themfelves by the manrer of confrueting their tents or huts. And to nill verfed are all the Indians in this dittinetion, thet Gicajba tiduse appeais to be no difference on the nicet ol

Corvatiog icaly dif ground, doniths

Ever: chief or ion at? x, to dir dit conce chief is 2 the greas toons, the creditar tent det propriet) 4ecelpit oilitesth

Miou: hand, anv ist the It bordinn opinion a his liberty tearance With fcor On thi Hidicreet iory itile thigg be on amon frith "int "of Wils litte Amon: Atablithed rate and adence 1 ramiat a Sor their a as füb" Git ends 
erring th conithed a" could 20 . 3 that the io what

appear 10 ncreafe $\mathrm{mr}$. pinion they

ivided into 2 little como As the na. it is diain: badge frovi le, the pan doweflies is bird i-fquir

Through. ves in the them vill himfelt b) ute the fup clive from attachment is origin, al

Slres by th And 10 helion, that he nicell ol:
Srvation uiade by an Furopeah, Jet they will immediciely difcorer, from the polition of a pole left in the ground, That nation bas eacimped on the fpot maty" donilis before.

Everf buid has a cbief who is termed the great chief or chief yartior, and who is cholen in confideraion of lis experience in war, and of his approved val$o$, to dires their military operations, and to regulate dit soncerns belonging to that department, But this chief is not confidered as the head of the ltate bisites the great warrior who is oleded for his warlike qualificitoons, there is another who enjoys a preminence as his Leredicary right, and has the more immediate manage tent of their civil affarts i' his chief might with greater propriety bo denominated the Sachem i whofe afront is 4 ceffir in all convey ances and treaties, to which he iilites the matk of the tribe or nation.

Though thefe two are confidered as the heads of the land, and the latter is ufually denominated their king, It tha It dians are Cenfible of neitber civil or military Cobrdination As every one of them entertains a high opinion of his confequence, and extremely tenasious of his liberty, all injunetions that carry with-them the ajs: Warance of a politive command are inltantly rejested With fcorn.

On this account, it is seldom that their leadets ase fo oidiferet as tó give out any of their orders in a peremp. tory tile $;$, bare hins from a chief that he thinks fucli thing beceffary to be done, infantly aronfes an emula. Won among the inferior ranks,and is inmediately execir. whith great alacrity: By this method the difgunful Int of the command is evaded, and an authority that alls litte thort of un abfolute fwhy inflituted in its room. A mons the thathns no vifible form of government is Rablithed: they allow of no Juch diltio stion as mages. ate and fubjes, every one appearing tu enjoy an inde. padence that cannot be controlled. The object of gnv. nmant anowing them is rather foreign than domeltic: Q their attention teens more to be employed in prefern s fúch an union among the members of their tribes a

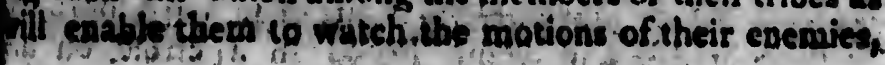


Ind act againt them with concert and rigor, than to maintain interior order by any pablic rugulations. If a fcheme that appears to be of fervice to the communi. ty is propofed by the chief, every one is at liberty to choofe whether he will affit in carrying it on, for they have no compulfory laws that lay them under any re. ftrictions. If violence is committed or blood thed, the right of revenging thef mildemeanors is teft to the fam. ily of the injured : the chiefs afluthe neither power of inticting or moderating the punithment.

Some nations, where the dignity is hereditary, limit the fucceffin to the female tine On the death of chief, his fifter's fon cometimes fucceeds him in pteffer ence to his niwn fon, and if he happens to have no fiftert the neareft female relation aflumes the dignity. This accounts for a woman being at the head of the Winne. bago nation, which, before $I$ was acquainted with theit laws, apjeared ltrange to me.

Eacl farity has a right to appoint one of jts chief to be an affitant to the ptincipal chief, who vatche over the inteteft of his family, and without whes con fent nurbing of a public nature can be cartied into exo

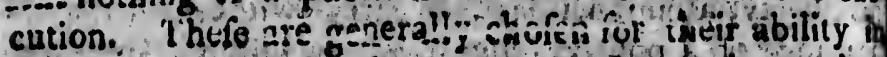
fpeaking $;$ and fuch only are permitted to take oration in their councils and general affeablips.

In this body, with the hereditary chief at fts head. the lupreme authority appears to be lodged as hy it determination every tranfaction relative to their hunting to their making war or peace, and to all their public con cerns are regulated. Next to thefe, the body of was riars which compiehends all that are able to bear arme hold their rank. This divifion las fometimes at its head the chief of the nation, if he has fignalized hithfeif $b$ any renowned action, if not, fome chief that hat render ed himale famous.

In their councils, which are held by the foregoins member, every affair of confequence ls dupatcd; an no enterprife of the leaf moment undertakep unlels there meete with the general approbation of the cbief The commonly affimble in a hut or tont oppropriate to this purpofo, and being feated in a cirde on th

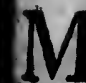

bread, falt, Gen or taft chár, have at tho wilk frirent parts at it alone Hill, withou Aance to al then they: 


\section{CARVER'S TRAVELS.}

7, than to ations. If communio liberty to , for they at any re. d thed, the to the fam. power of

ary, limit leath of: i in pteffer. e nó sit teet iify. This he winne. with theis (iis)

fjets chies io vatche when ion d' inio exe. tability in ke oration

if its head. as by its if hunting. public con dy' of war? bear arme at its head himseif b has render

foregoin ated, and 2. unleis i tive chiefs propriate Ste. on th ground the eldef chief rifes and ales a fpeech, When he has concluded, another gets up ; and thus their ail fpeak. if neceffary, by turne.

On this occafion their language is nervous, and their manner of exprefion emphatical. Their file is adorn. ed with images, comparifons, and frong metaphors, and is equal in allegories to that of apy of the eaftern antions. In all their fet fpeeches they exprefs them, Glves with muel rehemence, but in common difcourfe according to our ufual method of fpeech:

The young men are fuffered to be prefent at the councils, though they are not allowed to make a fpeech will they are regalarly admitied; they however litten with great attention, and to fhow that they both under. tand, and approve of the refolutions talien by the af Gmbled chiefs, they frequentiy exclaim, "That is right"? "That is good."

The c. tomary mode among all the ranks of expref fing the Teats and which they repeat at the end of almof el r period, is by uttering a kind of forcible af giration, which founds like an union of the letters OAH.

\section{CHAPTEK W.}

\section{or Trith Thasto}

M ANY of the Indian nations neither make ufe of Cread, falt, or fpices i and forme of them have never: Gen or tafted of eichers The Nandoweffies, in parice. ulár, bave no bread, nor any fubstiture for it. They at tho wild rice which grows in great quantities in diffrrent part of their territories, but ther boil it and at it alone. They alfo eat the fleth of the beafts they Lill, Githout baving neourfe to any fariaseceous is fis be Aance to abforb the groffer particles of it. And even

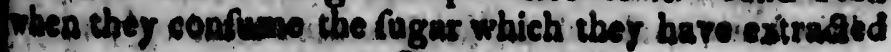
4. 8 
form the the ne tree the w we it not to rendet fom wher food palthila but generally eat it by itfelf.

Iveldige hove they any dea of the uff of milk. al Houghther wishteollea great quantities from the buffalo or els thog only confider it as propper far the nutriment of the joung of the fo beiflo duriog their tender fate. I could ant perceive that any inconveniency attended - total difufe of afticles eifemed fo neceltary and nu. tritious by the other nations, on the contrify, they are in genera healthy und vigorous

Q Ore dith however, which unfwers nearly tho fame parpole as bread, is in ufe among the Otrigaumies, the Savikes, and the more eaftern nations where I indian corn Gows, whith is not only much eftermed by hem, but r techongd evitrepely palatable by all the Europans who enter their dominions. This is sumpoled of their un. tipe corm as before deferibed, and beans in the fame Arte boiled together with beat's fleth, the fat of which thoiftens the pulfe, ana: renders it beyond comparifon delicipus. $T$ hes enll this food succutolh.

The Indians ore fat fopm being Cannibuls, is they are faid to be All their vianals are eithor roatted or boiled, and this in the extreme Their drink is gener. ally the broth in which it his betn boiled.

Their food confilts of the th the of the bear, the buffa. log, the elk, the deer, the betron and the racoon s which thes prepare in the thancar jut mentioned. They ufu. ally eat the fiefh of the detr which is raturally dry, with that of the beas which is fot and juics 8 and thougb obe latter is extremaly rich and lufcions, it is never known coloy.

In thefpring of the year the Nundowitifeseat the infide tark of a prub, that they gather in fome part of their

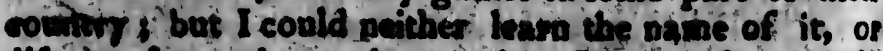

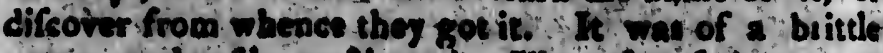
natrive and eafily malticuted. The cate of it was a

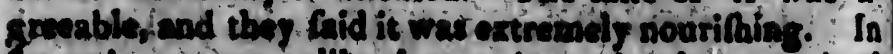
Lava it wis not ualite the turnip, and when received inco the mon sidernbled that root botti in its palpous ind frapgiblé natron:

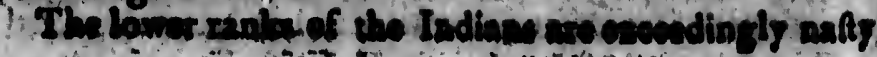

Wrefin ceat and Wirther: trits m without! bis ju? teits:?

They $\mathrm{x}$ and byith in to whe erery 800 ind unain Git apar ions, to pi bave f bu iom ne? No pso Indiarts. wibe the hofiof Ghil the comionon to prevale inon rend - When $t$ -y alwa ity and eh
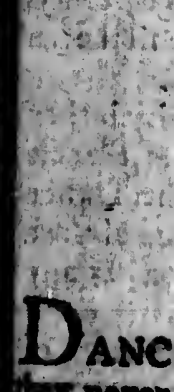

Why nover pars of thi nond in monefore 
ader fom itfelf.

milk. als the buffalu, nutriment ider Ante. attended $r y$ and nu. they are

the fame umies, the adian corn them, but peans who their un. the fame of which omparifon $+1$

4. As they roalted of $x$ is genes.

the buffo. pis which They ufu. erally dry, ad thougb ver known the inflide to of their of it, of a bittle it wae $2:$ labing. In seceived poilpous
Th dreffing their vietuals, bat fome of the chiefs are rery weat and cleanly in their apparel, tobts and to odd:

4. Ther commonly eat in large parties, fo that their trali may properly be termed feafts; and this they do withour being reftrieted to any fixed of i regular hourts (hit juh as their appetites require, and con venience thits:

They ufually dance either before or after every merals and by this cheerfulnefs probably render the Great S pirhi, to whom they confider the rorel ver as indebted for crery good a more acceptable facrifice than a formal ind namilnated thanks giving. The men and womeh feat apart and each fex invite by turns their compan fions, to partake with them of the food they happen to brve, but in their domeftic way of living the men and viomen eat together.

No people are more horpitableskindsand free than the Indianis They witl readily thare with any of their own. twibe the balt part of their provifions, and even with blof of $t$ different nation if they chanre to come in then they are eating. Though they do not keep one comolon flosk, yel that community of goods which is 60 prevalent among them, und their generous difpofiion, render it nearly of the fame effeet.

When the chiefs are convened un any putlic bufinerb they always conelude with a feaft, at whicts their feflivity and cheerfulnefs knows no limits.

a. $x^{5}, 3$

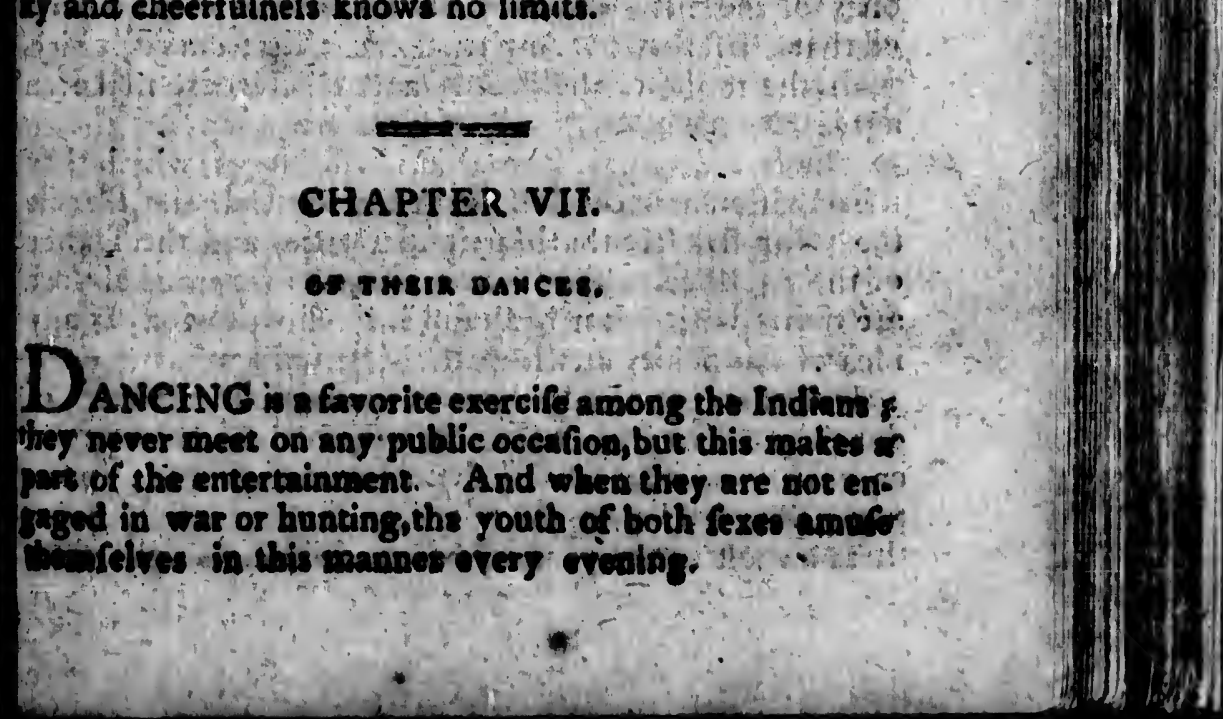


Whey alwaye dabcen at I have obferved, at theis feafs. In thefe as well as all other dances, every man tile's in his tutno end pnores about with great freedom and boldters of fingiag as he does fo, the exploits of his daceftorts During this the company who are feated on the ground in a circle around the dancer, join with him in making the cacenee, by -an odd tone, which they ut ter all trugether, and which founds, "Heh, heh, heh." Thefe notex, if they might be fo termed, are articulated with a hoxh eccent, and frained out with the utmof force of ithain lungs 8 fo that one would imagine their ftrength muit be loon exhaulted by it inftead of which; the r repeat it with the fame violence during the whole of their eatertainnent.

The women particularly thofe of the weftern aations, dance vert gracefully. They carry themfelves erea, and with thcir arms hanging down clofe to their fides, thone firft to the right, and then bad agait to the left. Thit movethent they perform without taling fepi as an Juropean would do, brit with thein feet conjoined; maring by curns theit toes and heels. In this mianner they glide with great agility to a certain diltance, and then return $f$ and let chofe who join in the dance be ev. er fo numerous, the) keep time fo exadly witli each oth. et that na interruption enfues During this at Aated perio twithey mingle their fhrill voices suth the hoarfer ones of the men, who fit anound (for, it is to be obferv. ed that the fexes neverintermix in the fame dance)' which, with the mulic of the drums and chichicoes; make an agreeabie harmony.

The Indians have feveral kind of dances, which they ufe on different occalions, as the Pipe or Calumet Dance, the War Dance, the Marriage Dance, and the Dance of the Sacrifice. Thes movements in every one of thefe are diffimilar; but it is almolt impoffible to convey any idea of the points in which they are unlike.

11)ifford inations tikewife varyin thoit manner of dancing The Chipeway throw themfel ves ipto a great ex variaty of altitiodes than any other poople i comea times thif hold thoir heads eree, at others they bend

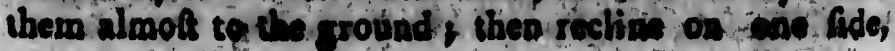

tofitelo

(uin, atri

the other?

fintint

onst the

inthealt ats thetere at do thith Nowe nitson $40, y$ hetatike? hranget th mernetut: What sant gationsy inting th itowitive

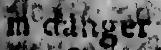
Wot fout Mity ifect iitend to find talke t to the ot in thite o them in as aflaydy froon de glade: X tus 
at their very man freedom its of his feated on with him b they ut ch, heh." rticulated e. utmolt tine their of which; luring the

neatione, nes erea, beir fides, to the left. Aeparasan: conjoined; is thanner ance, and nce be ev. each oth. at flated be hoarler be obferv. ce)'which, make an

Bicli they et Dance, he Dance he of thefe nvey any Dnner of oi great. 2. Jomea her bend now Ide'

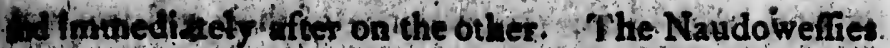
Wiry themfelves more upright, lep firmer, and move

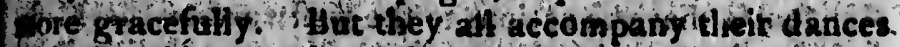

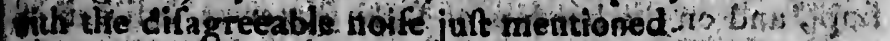

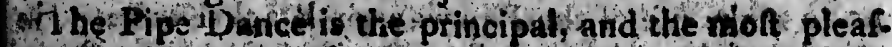

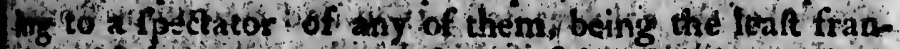

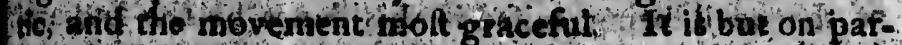

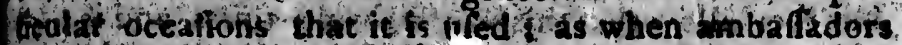

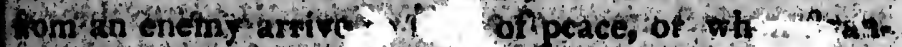

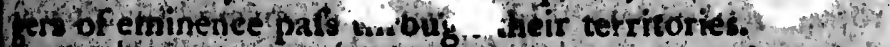

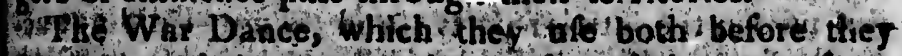

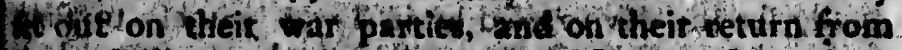

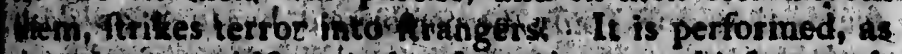

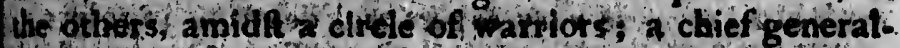

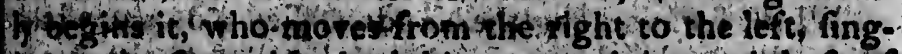

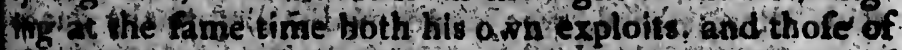

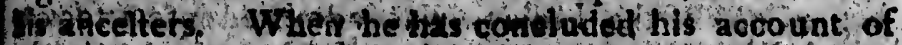

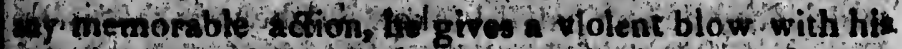

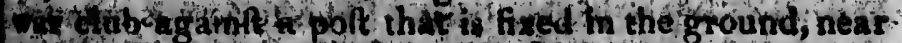

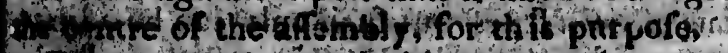

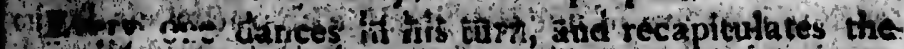

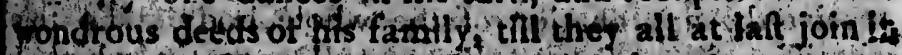
the dinter I PHente betomes truls alatibing to aty Winger that hapens to be ationg theth, as they throw

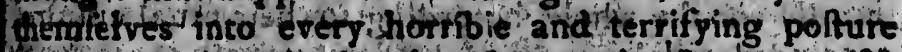
Whe can be imagined, rehearfing at the rame time the

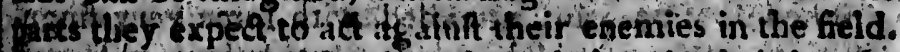
buting this the thold their that thives in theit hands,

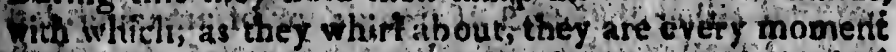

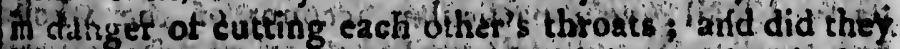
Wot nion the Itteatented mitchile with inconceivable dexWrity it could hbi be atolfed, bo thete motions thes Witend to teptefthe the rianner th which they kill, calp? Gid take theif prifoners. To beighteri the fone; the fet to the frime hideous yells, cries, and war whoops they ufe in the of atcion! fo that it is impoffible to confider them in any osher light than as an affembiy of dertions.

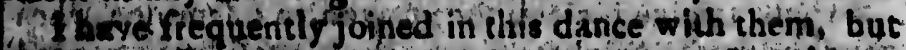

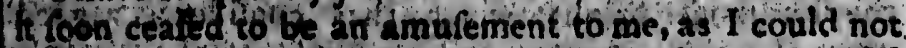

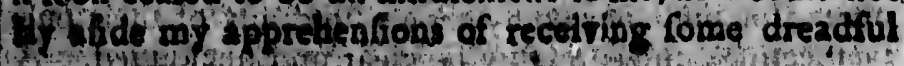


mound, that from the violence of hhair athares nut have prored mortab.

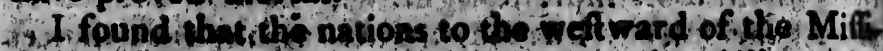
Appi, wod os that tordese of Laks Supopior, Alll contin

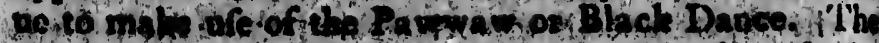

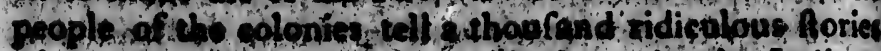

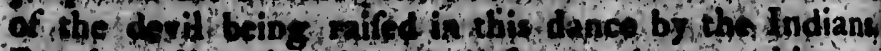

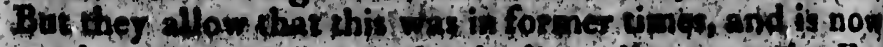

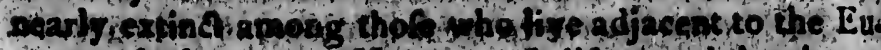

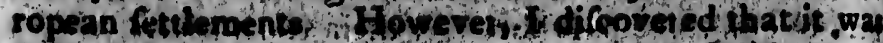

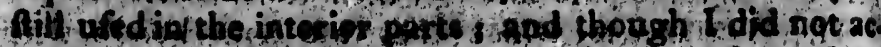

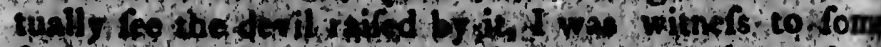
coses that could only te por fumed ibs lusb as deal

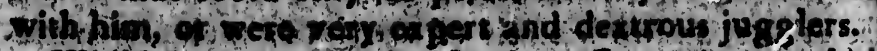

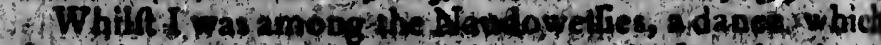

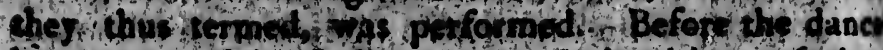

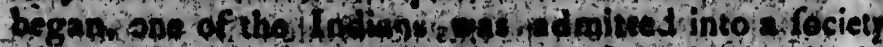

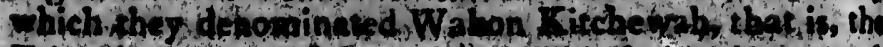

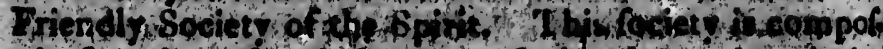

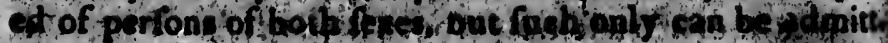

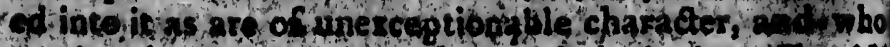
ceceive the apprabetion of the whole bods. Me thit

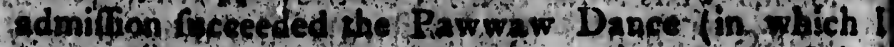
If nothing that sould give sile to the roports 1 bad henrd) ond the whele actordigs to their ufual cuftom concluded with a grand ffily

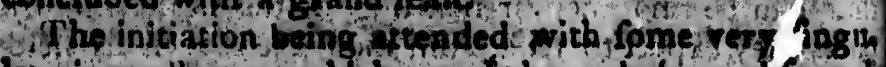

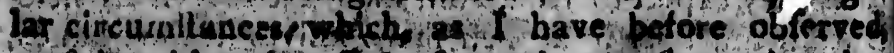
mus bo either the of et of inagic, ot of amazing dex terity, I hall give nipatisular account, of the whole

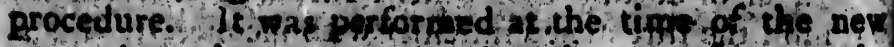
moon in a plactappropriated to the patpo on wear the centro of thoir camp that would contain bious t 0 hup dred people yocing a franger, and ond occalion treated by them with great civility, I was inyited to fee the ceremon's and placed clofe to the railo of the ene clofure ${ }^{2}$.

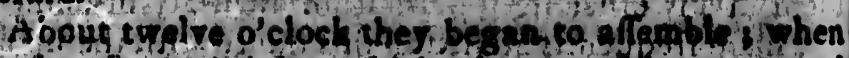

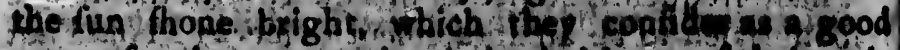
opten, for thes niver by choice hold en of the pub

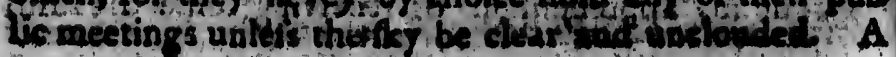

Whind (t) She. wior, Erioui rons, Monted incets Slowter swerto Whet 4.one o: anderly?

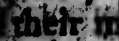
ontids m ad talisin

ingth section: Mob rotisin Ther

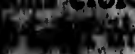
40 sol hold placed efalli ar bout twe This di

wore the thian a Sil now. fot mo ithe him atin to owever Aridtag son on As the Mit at watitice $v$ Acturis jo thint 
which feemed to enter his mouth, and he infanty fall as motionlels as if he had been hot. The chief that was placed behind him received him in his arms, and by the affitance of the other two, laid him on the ground to all appearatice bereft of life

Having done this, the I impediately began to rub his limbs, and to Arike him on the back ging him fuch blows is feemed more calculated to Btil the quick, than to raife the dead. During thefe extracordinary ap. plications, the fpeaker continued his harangue, defiring the fpectators not to be furprifed, or to defpait of the young man's resovery, as his prefent inanimate fitua tion proceeded only from the for cible opperation of the fpirit on faculties that had hitherto been unufed to im Ipirations of this kind.

The candidate lay feveral minutes whout fenfe of motion ; butatlength, fter receiving many violent blows he began to difcover fome fy mptons of returning life Thefe howeven were attended witl frong convulion, and an apparent obltuctiun in tis thront But they were foon at an end 3 for heving difchaiged fre his month the bean, or whatever it was that the chic had thrown at him, but which on the clofeft inf pection I had not perceived to eiter it he 1000 after appeared to be tolerably recovered.

This part of the ceremony being happily effeted, the officiating chiefs difrobed him of the clothes he had ufu ally worn, and put on him a let of apparel eritirely new. When he was drefled, the fpeaker otice more took him by the hand and prefented him to the focitty 25 a reg. ular and thoroughly initiated member, exhorting them, athe fame time, to give bim fuch necefary affitance, as bing a young mernber, he might ftand in need of. If then also charged the newly eleaed brother to re ceive mith tumility, acd to follow with punsuality the advice of bis elder brethren.

All thote who bad been admitted within the rails now formed a circle around their new brother, and the mufic Ariking up, the gret chief fung a fong, celebra. ling as ulual thel martial ox of to

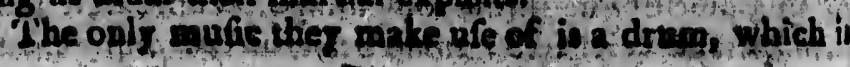

fonpor over

heat with from har To this $\mathrm{t}$ inat dane of a res

The w dence be their roin certain in but fivae: able ente I coula coflom I which we conjurati hands an from the trade $\mathrm{a}$ fo organical inilrumen pany, ani Gantly fel or three, gether $: 1$ joined ag the chiefs learned t Gods.

Afterf the dithe! conflifed their pub other kin am now logs, if $t$ In this cafions, countries Theruth 
Lind y f t chief that arms, and the ground

gan to rub 3ixing him Ithe quick, rdinary ap. ie, defiring vait of the, pate fitua. tion of the cured to in

at fenfe or lens blows ing life onvplifions But the) 3 frowis chich had cetion I had ared to be

ffected, the be bad ufuo tirely. new. took him ys 75 a reg. ruing them, alfifance, in need of. ther to reo Auality the

the rails I, and the 8. celebra 30 which is manp af a piece of a hollow tree curioufly wrought; tand over one end of which is frained a Akin, this the Weat with 2 fingle fick, and it gives a found that is far from harmonious but it jult ferves to beat time with. To this they fometimes add the chichicue, and in their wat dances the y likewile ufe a kind of fife, formed of a reed, which makes a thi ill hath noite.

The whole affembly were by this time united and the ance began, feveral fingers affited the mulic with their roice, and the wonien joining in the chorus at certain intervals the produced together a not unpleafing but favage hurmony. This was one of the molt agret. ble entertainments I faw whilh I was among them.

I could not help laughing at a fingular and childith cufom I oblerved tiey introduced in:o this dance, and which was the only one that had the leaf appearance of conjuration. Mof of the thembets carried in their hands an otter of martin's fkin, which being taken whole from the body, and filled with wind on being compreffed tade a fqueakiry hoife through a fmall piece of rood organically formed and fixed in its mouth. When this initrument was prefented to the face of any of the com. pany, and the found emitted, the perfon receiving it in. thantly fell down to appearance dead. Snnetimes two or three, both men and women, were on the grcund to: gether \& but imnediately recovering, they rofe up and joined again in the dance. This feemed to aford even the chiefs themfelves, infinite diverfion 1 afterwards learned that thefe vere their Dii Penates or Houfehold Gods.

After fome hours fpent in this manner the fealt began; the dithes being brought thear me 1 petceived that the confifted of dog's fieth; and l was informed that all their public grand fealts they never made ufe of any other kind of food For this purpofe, at the feat I om now fpeaking of, the new candidate provides fat Oogs, if they ean be procured at any price.

In this cufom of eating dog's flef on particular oc. cafichs, they tefomble the iribubitants of rome of the countries that lie on the nurth call borders of Afia. The puthor of the account of Kamrchatkt, publithed. (3) 
by order of the emprefs of Rutia (betote referted io) informs us, that the people inhabiting Koreka, a coun try north of Kermfehteka, who wanderf bout in hordes like the Arabs, wheri they pay their worthip to the evil being Kill a thin deer or a dag, the flelt of which they eat, and leave the bead and tongue tticking on a pole with the front towards the eaft. Alfo that when they are a. fraid of any infectious ditemper they kill a dog, and winding the guts about two poles; pars between them Thefe cuftoms, in which they are nearly imitated by the Indians, feem to add ftength to $\mathrm{m}$ fupposition, that A merica was firt peopled from this quarter.

I krow not under what elafs of dances to rank that performed by the Indians who came to my tent when I landed near Lake Pepin, on the banks of the Miffifippi, as related in my journal When 1 looked out, as I there mentioned I fav about twenty naked young in. dians, the mult perfest in their fiape, and by far the Landfome of any I had ever feen, coming towards me. ard daticing as trey approached, to the mulic of thei Jrums. At every cen or twelpe yards they halted and fet up their yells and cries.

When they reaclied my tent, I alked them to come in; which, without deigning to make me any anfwer, the did. As I obferved that they were painted red and black, as they ufualey are when the go againt an ene.

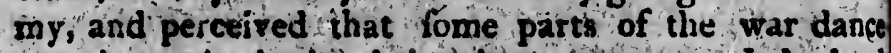
were intermixed with their other movements, I doubted not but they were fet on by the inimichl chief who had refufed my falutation 1 therefore determined to fell my life as dear as poffible. To this purpole, I re ceived them fetting on my chel, with my gun and piflois befide me, and ordered my men to keep a watcliful eje on them, and to be alfo upon theif guard

The. Indians being entered, they continued their dance alternately, finging at the fame time of their heroic ex pluits, and the fuporiority of their tace over every oth i peuple. Io enforce their language, though it wa uncummonly nervous and exprefive, and fuch as would - of itfel have caried tets or inio tho firmelt heat,

thend o tinit th that $I$ exp ipon us. loee by $n$ Tes, and Gee, whic (ip. $\mathrm{My}_{\mathrm{Y}}$ adge for I heolions Whent 10 them 2 then, as prélents 1 Come ribat Thefe fee rest in 60 confultatio which Itc Thus it pipe of $\mathrm{pe}$ and then 1 rook ep t ind appea a a frienc pleafure $t$ If Was Age br 4 carón to. tist, at fo tion of th formed, th her ulua sappen to a their ne, were A to imp ted an e? in the mi their wive thom if 
reterined io) sa, a coun: hordes like evil being. ey eat, and le with the hey are a. a dog, and ween them. mitated by luppósition arter.

o rarik that tent when I e Miffifippid d out, as 1 3 young $\mathrm{In}$. by "far the owards tie itic of their halted and

to come ini nfwer, the $d$ red and init an ene. war dance I doubted ef who had ined to fell poie, I re. gun and to keep 2 upon their

their dance hetoic er. every oth ugh it (wes) h as would At heat, a the end of every period they Rruck their war clubs awint the poles of $\mathrm{my}$ teat, with fuch violence, that lexpeged every momint it would have tumbled upon us. As each of them, in dancing round pafted lose by me, they placed ikeir right hinds over their Fes, and coming clofe to me, looked me fteadily in tive free, which I could not conitrue into a token of fricud. Wip. My men gave themfelves up for loft, and I acknowledg for my oun part that I never found my apprebealions more tumultuous on any occafion.

When they had nearly ended their dance, 1 prefented 60 them the pipe of peace, but they would not acsept it. lithen, as my laft refource, thought I would try what prefents wouid do / tecordingly I tuok from my cheft bome ribands and trinkets, which 1 laid before them. Thefe feemed to Aagger their refolutions, and to areat in fome degree their anges ; for after bolding a confultation together, they lat down on the ground; which I confidered as a fayorable omen.

Thus it proved, as in a thort time they received the pipe of peace, and lighting it, firt prefented it to me. and then Imoked with it themfelves. Soon after they rook up the prefents. which haj hitherto lain negleated, Ind appeating to be greatly pleafed with them, departed fo triendly majner. And never did-I receive greater pleafure than at getting rid of fuch formidable guefts. If was never in my power to gain a thurough know?dot of the defigus of m/ viftors. I liad fufficient Waron to fonclude that they were holtile, and that their Hifi, at fo tate an hour, was made through the inftigaion of the grand Saviot : but $T$ wa aftertwards informed that it might be intended as a compliment which they ufually pay to the chiefs of every ollier nation who appen to fall in with th. $m$, and thit the circumitances in their conduef, which had appeared fo fufpicious to ter were merely the effects of their vanity, and defign. ad to imprefs or the minds of thole whom they thus vis. ted an elevated opinion of their valor and prowefs. In the morning ofore I continued my roule, feveral of lheir wives brought me a prefent of forme fugar, for Whom I found a fer more ribends. 
The dance of the facrifice is not fo, denominated from their offering up at the fame time a facrifice to a: ny good or evil fpirit, but is a dance to which the Nau. dow efies give that title from being ufed when any pub. lic fortunate circumftance befals thea. Whillt I refi. ded among them a fine large deer accidentally frajed into the middle of their encampment, which they foon deltroyed. As this happened juft at the new moon,they efteemed it a lucky omen and having roalted it whole every one in the camp partoot of it: After their feal, they all joined in a dunce, which they termad, from its being fomewhat of $a$ religious nature, 2 dance of the facrifice.

\section{CHAPTER VIII.}

OF THEIR HUNTINQ.

$\mathrm{H}_{0}$

UNTIRG is the principal occupation of the In. dians; they are trained to it from their earlieft youtb, and it is an excercife which is efleemed no lefs hoviona ble than necelfary towards their fubfiftence $A$ dester ous hunter is held nearly in as great eftimation by them as a difinguifhed warrior. Scarcely any device which the ingenuity of man has difcorcred for enfriaring of dêtroying thofe animals that fupply them with food or whofe oking are valuable io Luropeans, is unknows to them.

Whilt they are engaged in this exercife, they Nate off the indolence peculiar to their nature, and becom active perfevering, and indefatigable. They are equal ly fagacious in finding their prey, and in the means the ufe to deftroy it. I hey difeern the footleps of th bealts they are in purfuit of, although they are imper ceptible to evers other eje, and can follow them will sertainty through the pathlefs frreft.

Ithe bealts that the Indiana hunt, both for their ferthe

which their ap ries, atc boo, the ing 2 d only at them.

the $\mathrm{s}$ that that yeneral when all cluded o regulate Toiemnit (1) attenc knowled compulf himfelf ।

The I on the $r i$ abfalin fuch is $t$ treeme water ; cheerful The is en.ibles : informed game itib, and i thele oce are unco

the fa known, tealt io $\mathrm{t}$ which no ed thems falked to chier that of titore her aro: 
enominated crifice to a: $h$ the Nau: on any pub. iilit I refi. ally Arajed ithey foon moon,they ed it whole their feall, a, from its ince of the

of the In. lieft youtb, lefs hosiora. A dester ion by them evice which ofraring of with food is unknown

they Alak. and becom y are equm? means the Reps of th are imper them will their fleth o

Which they fublil, and for their Akins, of which they make their apparel, or barter with the Luropeans for neceffa. ries, ate the buffalo, the elt, the detr, the moofe, carriboo, the bear, the beaver, the martin, \&c. 1 defer giving a defcription of thefe cteatures here, and thall only at prefent treat of their manner of hunting them.

the rnute they Shall take for this purpore, and parties that thall go on the different expeditions are fixed in the general councils, which are held fome time in the fummer, when all the operations for the enfuing winter are con. cluded on. The chief varrior, whofe province it is to regulate their proceedings on this occafion, with great foiemnity iffues out an invitation to thofe who chnofe wi attend him, for the Injians, as before obferved, ac. knosledge no fuperiority, nor have they any idea of compulfion, and every one that accepts it, prepares himfelf by falting feveral days.

The Indians do not fal as forne other nations do, on the ridbes and molt luxurous food, but they totally abftalin from every kind either of vietuals or drink; and fuch is their patience and refolucion, that the moft extreeme thirt could not oblige them to tafte a drop of water f fet amide this fevere abftinence they appear cheerful and happy.

The realons they give for thus falling, are, that it enables thiem freely to fream, in which drealins they are informed where they thall find the greatef flenty of garpe alfo that it a berts the difplealure of the uvil fpiriis, and induces them to be propitious. They also on thele occalious blacken thole purts of their bodies that are uncoviered.

The falt being erded, and the place of huliting made known, the chief who is to conduit them, gives a grand teall to thote who ate to form the differene parties of which note of them dare to paitake till they have bath. ed themfelves. A this fealt, nb? withriading they have falnd to long they ext with great modetation s and the chice that prelides tholoy shimself in rehearfing the feats of thole who have been molt succelsful in the bufizers

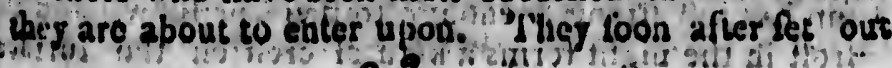


on the march towards the place appointed, painted is rather bedawbed with black, amidt the acclamations of all the penple.

It is im poffible tc defcribe their agility or perfeverance, whilt they are in purfuit of their prey i neither thickets, ditches, torrents, pools, or rivers ftop them : they al. wayss go frait forward in the molt direct line they poffi. bly can, and theic are few of the favage inlabitants of the woods that they cannot overtake.

When they hunt for bears, they endeavor to find out their retreats for, during the winter thefe animals conceal themfelves in hollow trees, or make themfelves boles in the ground, where they continue withuot food, whilf the fevere weather lafts.

When the Indians think they have arrived at a place whete thefe creatures ufually haunt, they form then felves into a circle according to theit number, and mor. ing onward, endeavor as they advance to wards the cen. tre, to difcover the retreats of their prey. By this mean's, if any lio in the intermediate fpace, the are fure of a roufing them, und bringing them down either with their bows ur guns. 'the beary will take to ftight at fight of a man or a dog, and will only malse iefillance when they are extremely hungiy, or after they are wound ed.

The Indian tmethod of hunting the buffalo is by form ing a cilcle or a Square, nearly in the fañe muner a when they fearch for the bear. Having taken their dif ferent Atations, they fet the grars, which at this time i ra nk and dry, on fite, and thefe animils, who are es tremely fearful of that element, lying with precipita tion before it, great numbers are heromed in a fnial compar, and carcely: a fingle, one efcapes.

They have different ways of hunting the elk, th deer, and the carriboo Sometimes they fkek tiem of in the woods, 10 which they ietire during the feverit of the cold, where they are ealily hont from behund th trees. In the more no:thern climates they take tlie ad vantage of the weather to dellros the elk whin th Sun has jult Arength enough jo melt the tnow and of trolt in the night forms a kind of crelf bi the Surfar

this cre and ty this ti trojed:

Som inals th ger. 1 bainds a one par other fo the Han and by thefe bo into whi of them main in

Both they are fuers 20 finds to foek for this met with th rer.

But th thofe'sh thetrifelv vantage, througho during grosteft ry anim: ylations give 'in' a The $h$ them.? king ther thetr'cau As the Hething of in aps 
jalinted is mations of

reverance, thickets, they al. they pofli. abitants of

to find ot: fe animals themfelves thout food,

1 at a place orm then. $r$, and mor. irds the cen. this means, Ture of $:$ is with their at fight of lance when are wound

is by form mariner a en their dis this time i who are es 5. precipita in a fnal

the elk, th ek thiem or the feverity $a$ behind in take the ad whin it sw. alid th the Curfár this creature being heavy, breaks it w th his forked hoofs, and with difficulty extricates linmleif from it : at this tinte therefore he is foon overtaken and des trojed:

Some nations have a method of hunting thefe ani. mals thich is tnore ealily executed ind free from dan. ger. The hinting party divlde thetnfelves into two bands and choling 2 lpot near the borders of fome river, one party embirks on board their canoes, whilft the other for ming themfelves inig a femi cirole on the land, the Hanks of which reach the fhore, let toole thieir dog's, and by this neans rome all the game that lies within thefe bounds $f$ they then drive them towards the rivert into which they no founer enter, than the greatêt part of them are immediately difpatcked by thofe who remain in their carioes:

Both the elk and the buffito are vory furious when they are wounded, and prill returi fiercely on their purfuers and trample triem under their feet, if the hunter filids no means to complete their defruetion, or does not feek for fecutity in flight to fome tidjacent tree; by this method they are frequenkly avoided, and fo tired with the purfuit, that they volenterily give it 0 . rer.

But the hunting in which the Indians, particularly thofe"sho inhabit tlie "riorthern parts, chiefly employ thetniflves, and from which they reap the greatef ad: vantage, is the beaver hunting. The feafori for this is throughout the whole vinter, from Novemhet to A pril'; during which time the fur of thele creatures is in the grateft perfection. A defeription of this extrabtidinaiy animal, the confluction of their' huts, and whe reg. ylations of their almoit rational combunity, I Thall give 'in' another place.

The hunters make ufe of fiveral methods to deftroy unem. Thole generally practifed, are either that of taking them in fliares, cutting throulgh the ice, or opening their cxufenays:

ailin the eyes of thefe andmals dre ver! quick. and their

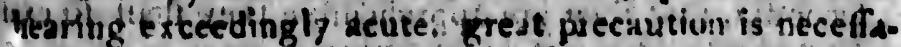
is in approaching their budius; for as they feluom go 
fir from the water, and their houfes are always buils clofe to the fide of fome large river or lake, or lams of their own coniftructing, upon the leaft alarm they hatt. ein to the deepelt part of the water, and dive immediate. Ij to the bottom ; as they do this, they make a great noife by beating the water with their teils, on purpofe to put the whole fraternicy on their guard.

They take them with fnares in the following manner: though the bedvets ufually lay up a fufficient ftore of provifion to ferve for their fubfritence during the win. ter, thet make from time to time excurfions to the neighboring wood $\$ 9$ procure further fupplies of tood. The hunter having founa out their haunts plars atrap in thair way, baited with fmall pieces of bark or young thoots of trees, which the beaver has no fooner laid hold of than a large $\log$ of wond falls upon hian, and breaks his back 2 his enemies, who are upon the watch, foon appear, apd infeptls difpatch the helplefs animal.

At other times, when the ice on the rivers and lakes is, about half a foot thick, they make an opening through it with their tatchets, to which tne beavers will foon hatien, on being dilturbed for a fupply of freth air. As their breath occufione, a confiderable motion in the water, the hunter has fufficient notice of their approach, and methods are eafily taken for krocking them on the head the mongent they appear above the furface.

When the boufes of the beavers bappen to be near a fivulet, they are more eafily deftroyed the liunter then cut the ice, and fpread a net under it, break down the cabins of the beavers, who never, fail to make to widds the deepelt part, where they are entangled and takt But they muft not be fuffered to remain ther long, is thes vould foon extricute themfelves with then teeth, which are well known to be exceffively thasp and Arong.

The Indians take great care ta hinder their dngs from touching the tones of the beavers The realons they gif fur thele precautions, ure, firh, that the bones, 1 e foe cellively hard, that the fppil the teetlr of the dogs and fecondly, thit they are approhenfire, they fhall to exe

perate

to rend The the Eur red by. the gre:

Whe they gei Ken ame ing the. the fpoil they $g$ to uhei muring parent

Ano buffalo, it drops, being ne lidered a had beet this cuitt people cl ever, ver on the b: hits, is ex

or

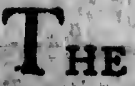
teen, and fixty. S formed; thet ate 1 In evir 
ays built or dams of they hat. mmediate. ke a great on purpofe

gg manner: ent fore of Ig the win. fions to the lies of tood. plare atrap $k$ or young fooner laid $n$ hisa, and the watcl, lefs animal. rsiand lakes ing through is will foon ff freth air. btion in the ir approach, them on the rfice.

o be near a the liunters break down to make totangled and main ther es with their ly, therp and ir dongs from snithey giv hes, aje fo et dogs 8 and thall to ext perate the fpirits of the beavers by this permillon, as to render the next huiting feafon unfuccefsful.

The Akins of thefe animals the hunters exchange with the Europeans for neceffiries, and as they are more valwed by the latter than any other kind of furs, they pas: the greated attention to this fpecies of hunting.

When the Indians deltroy buffalos, elks, deer, \&ce. they generally divide the fleth of fuch as they have taken among the tribe to which they belong. But in hunt. ing the beaver a few families ufually unite and divide the fpoil between them. Indced, in the firft infares they generally pay fome attention in the divifion to their awn families; but no jealoufies or mur murings are eves known to arife on account of any apa parent partiality.

A mong the Naudowefles, if a perfon lhoots a deer, buffalo, \&c. and it runs to a confiderable diftance before it drops, where a perfon belonging to another tribes. being nearer, firft fticks a knife into it, the game is confidered as the property of the latter, notwithltanding it had been mortally wounded by the former. Though this cultom appeurs to be asbitrary and unjuft, yet that people cheerfully fubmit to it. This decilion is, however, very different from that practifed by the Indians. on the back of the colonies, where the firt perfon that hits, is entitled to the belt fhares

\section{CHAPTER IX.}

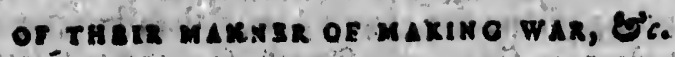

$T$

1 HE Indians begin to bear arms at the age of tfteen, and lay them abide when they arvive at the age of fixty. Somc nations to the fouthward, I have been informed do bot continue their military exerciles after thes are tifty.

In eviry band or nation there fo a foled number who 
are filed the warriors and who arealways ready to at either offenfivel or Jefenfively, as occafion requires. Thefe are well armed, bearing the weapans commonly in ufe among them, which vary according to the fituation of their countries such as have an intercourfe with the Eurupeans make ufe of tomahaw ks, knives; and fre arms i but tho fo whofe dwellings are tituated to tho weft ward of the Miflfippi, and who bave not an opportunits of purelanfing thefe kind of weapons, uie bows and aroows, and alfo tho Caffe Tetes or War Club.

The Indians that inhabit aili further to the weftward, a country which extends to the fouch Sea, ure in fight 2 warlike inftrument that is very uncammon. Having great plenty of horfes, they always attack their enemien on horfeback and ancumber themfelves with no other weapon thán 2 fone of a middling fize, curioufly wrought, which they falten by a Aring, about a yard and a half long, to their rught urms, 2 litcle above the elbow. Thefe fones they conveniently carry in their hands, till ther reach their enemies, and then fwinging them with great dexterity, as they ride full fpeed, never fail of doing execuition. The country which thefe tribes poffefs, abounding with large extenfive plains, thofe who atiack them feldom return; is the furiftnefs of theis horfes, on which they are mounted, enables them to 0 . vertake even the fleet $h$ of their invaders.

I'le Naudoweffies, who hád been at war with this people info-ned me, that unlers they found moraffes or thichists to which they could retire, they, were fure of being cut off : to prevent this thuy always ţook care whenever they made an onfet, to do it near fuch retreats 2s were impafisble for caralry, they then baving a great advantage over their enemies, whole weapons would not there reach them

Some nations make ufe of a javelin, pointed with bone worked into different forms 1 bnt their Indian wap pon in genoral are bows and arrown and the thort club at rendy mentioned. The latter is made of a very hard wood, and the head of it falhioned round like a bill, a wout three inches and half diameters ip this round

part is cither of Inter and of 2 dount ho otiginall bad con bave for inclies, ial dies toroa cts towat of deer's quills ; a the fame brealt.

principal Gltrumen I otrér. thields $\mathrm{m}$ thofe ufed was Inuall thishich 1 rofe chofe many gen The re: me anoth wivilized $\mathbf{n}$ eightibors. ral more" Turopeans The ex hefe peop te territo Jo fecure s, to:main ftorned $t$ onfider fru fringeme at fo of te thich are c Chough 
Iy to act equires. mmonly he:fitua:ercourfe knives, thtuated ve not an pons, ule or Was

weftward; in fight 2 Having ir enemier h no other curioufly t 2 yard above the is in their a fwinging beed, never thefe tribes hins, thole pers of their them to 0 .

with this moraffes or pere fure of s took care ch retreats ing 4 great would not

d with bone an weapons ort club al. 2 very hard se a ball, athis round part is fixed an edge refembling that of a tomahawk, ather of fleel on fint; whichfacerer they can procure,

The dagger is peculiar te the Natido weffie nation, and of ancient conftruction, but they can give vib atount how long it has been in ufe anong them. It was otiginally made of flint or tione, but tince they have had communicition with the European traders, they hive formed it of Reel. The length of it is about ten ithelies, tand that part dofe to the handle nearly three in. ches troad Its edges ate keen and it gradually tap. cis towards a point. Whey wear it in theath made of deer's leather, theatly orndthented with porcupine quills ; and it is ufnally bung by a aring, decorated in the fame manner, which tedches as low ohly as the bealt. Lhe tearicias weapon is vorn by a few of the irinciphal chiefs alone, ind confidered both as an ufeful infrument, ond ai ornamental bauge of fuperiority: I obferved among the Naudovielfies a few targets or Gield's made of raw buffalo thides, and in the form of hofe ufed by the ancients. But as the number of thefe. was Inall, and I could gain no intelligence of the are th which they fio were introduced om mo them, I fuppofe thole I faw had defcended from father to fon, for many generations.

The reafots the Indian give of making wat againft one ahother, are much the ame as hole urged by more ivilized nations for difturbing the tra nquility of their aeightors. The pleas of tlie former are however in gen. ral more rational and jut than fuch as are brought by Huroperans in vindication of their proceedings?

The extenfion of empire is feldom motive with thele people to invade, and to commit depredations on he territoties of thofe who happen to direl near them. to fecure the rights of hunting within particular limsis to maintain the liberty of paffing through their acifoined tracks, and to guard thofe lands which they onfder from a long tenure as their own, againt any fringement, are the general caules of thore diffentions at fo often break ouc between the Indan nations, fand thich are carried on with to much animofity

Chough flrangers to the idex of feparate property, 
yet the moft ureultirated among them are well acs quainted with the right of their community to the do. mains they poffers, and oppofe with vigor any encroach. ment on them.

Notwithltanding it is generally fuppofed that from their territories being fo extentive, the boundaries of them cannot be afcertained, yet $I$ am well affured that the limits of exeh nation in the iuterior parts are laid down in their rude plans with great precilion. B) theirs, as I have before eblerved, was I enabled to regulate my own and atter the moft exact obfervations and en. quiries 1 found very fow inlances is which they erred.

But interef is not either the molt frequent or moft powerful incentive to their making war on each other. The pattion of revenge, which is the diftinguithing char: acterific of thefe people, is the molt general motive. Injuyies are felt by them with exquifite fenfibility, and Yengeance purfued with unremitted ardor To thi may be added, that natural excitation which every in dian becomes fenfible of, as foon as he approaches the age of manhood to gire proof of his valor and prowefs.

As they are early poffeffed with a notion that wat pught to be the chief bufinefs of their lives, that there Is nothing more defrotis than the reputation of being a geat warrior, and that the fcalps of their enemies, of a number of prifones are alone to be elteemed valua ble; it is not to be mudered at that the young Indian are continually relters and une $f y$ if their ardor is te

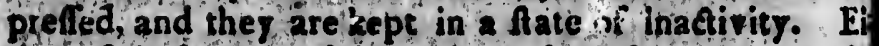
ther of thefe propenlitives, the defire of revenge or th gratifiestions of an impulfe, shat by degrees becomes habitual to them, is fufficient, frequently, to induce the to commit holtilities on fome of the reighboing $n$ tions.

Whon tbe chiefs find any occafinn for making wai they endearur to aroufe thefe habitudes, and by tha means foon extite their warriors to take arms. I'o thi purpofe they make ufe of their martinl eloquence, neal Iy in the following words, which never fails of provin cifcetual, "the bones of our deceafed countrymen ? uncorered, they call out to us to revenge their wriag

and pre gainit we the 1 iion to of Let us 8 fit there fyour atity jour foin they That

Animia heir arm ind butn Jood of: Sometii ate exc tyar, or rompted ill mare iprife 2 Thereir of by $t$ connive Navido But whe moniunit he elders arriors an fer theit. iturity th gage in vantages Theistpr ifotidetin pemen is a If the de id much The chie foons heta tes a wat odópinio 
well acs o the do. encroach.

that from ndaries of Tured that ts are laid B) theirs, o reguiaie ons and en. they erred. ent or molt each other. ithing char: ral motive. fibility, and r. To this h every ln. roaches the nd prowefn. ion that was , that these $n$ of being 2 enemies, of med valua ung Indian ardor is $\mathrm{r}$ Sivity: Ei enge or the ees beconme. induce them huboring $\mathrm{n}$ naking war and by tha ms. I'o thi quence, neat is of provin untrymen li Sheir wriasg and we mult fatisfy their requel. Their fpirits cry out Gainit us. They mult be appeafed. It the genii, who We the guardians of our honor, infpire us witha refole. ilon to feet the enemies of our muadered brothere. Let us go and dévour thofe by whom they were flain. Sit therefore no looger inactive, gire way to the impulfe of your natural valor, anoint your bair, paint ycuir fat W fill your quivers, caufe the foreft to refound with our frings, confole the fpirits of the dead and tell them they thatl be revenged.?

Animated by thefe exhortations the warriors fnatch their arms in a tranfport of fury, fing the fong of what, ind butn with impatience to imbrue their hands in the Jood of their enemies:

Sometimes private chiefs affemble fmall parties and ale excurfions aguint thofe with whom they are War, or fuch as have injured them. A fingle warrion, ompted by revenge or a deffre to thow his prowefs, ill march unattended for feveral hundred miles, to iprife and cut off a Atraggling party.

Thefeirregular fallies however,ate not always appraw of by the elder chiefs, though they are often obliged connive at them 3 as in the inftance before given of Navodowelfie and Chipewas nations

But when a war is netional, ard uoderiaken by the ommunity, their deliberavions are formal and flow. he elders affemble in council, to thich alt the thead arriors and young menate admitted, where they dea ter theit opinions in folemn fpeeches, weighing with inturity the nature of the enterprile they ian boout is gage in, and balkancing with great fagacity the ivantages or inconvenievices that will arifo from it. Their priefts ate alfo confulted on the fubjes, and er. if fometimes the advice of the moll intelligent of their omen is alked.

If the determination be for war, thes preptre for it ith much ceremony.

The chief wartior of the nation does not on all de. Gons hetad the wat party limfelf, le frequently do tes 2 wartior of where valor ahd prudence he bath dopinion. The porfon chus fixed on being Gra be 
dábed with black,oblerves a falt of feveral days, during which he involes the Great Spirit, or deprecates the a gez of the evil ones, holding whill it laits no converfe with any of his tribe.

Heis particularly careful at the fame time to obferv his dresms, for on thefe they fuppole their fuscers wil in a great meafure depend and from the firm perfua fioneves $y$ Indian actuated by his $\rho$ p prefumptiou thoughts is impreffed with, that he thall march forth of certain victory, there are generally fuvorable to hi wilhes.

After he has fafted as long as cuiftom prefcribes, be affembles the warriors, and holding a belt of wampun is his hand, thus addreffes them:

1. Btothers ! by the infpiration of the Great Spirit now f peak to you, and by him I am prompted to carsy into execution the intentions which $I \mathrm{am}$ about to dif clofe ta you. The blood of our deceafed brothers not yet wiped away their bodies are not yet covered and Lam going to perform this duty to them:"

Having made known to them all the motives that in duce him to take-up arms againft the nation with whol they are to engage, he thus proceeds : I have thers Fore refolved to march through the war path to furprif them. We will eat their fleth and drink their blood we will take Icalps and make prifoners, and thoul we perith in this glorious enterprife, we thall not be for ever hid in the duft, for this belt thall be a recompenf to him who buries the dead." Having faid this, he la) the belt on the ground and he who takes it up declare himfelf his lieutenant, and is confidered as the feccond, command this, however, is only done by fome difti guifhed wririor who has a right by the number of $b$ fialps to the polt.

Though the Indiars thus affert that they will eat th fieft and drint the blood of their enemies, the threat only to be confidered as a figurative expretion. $\mathrm{No}$ withitanding they fometimes devour the bearts of tho they flay, and drink their blcod by way of bravado, to gratify in a more complete manner their reveris

jet they

a the fl

The c ointed $x$ in fuch $f$ is enem thies his ojes opo Spirit, is niors.

Ihis c have befe kilf whi

This fe rior; to $x$ his exped the feialt, compofed the valor As the ceive any - fome a Lemfelve Ifo their fficaciou roots and the powe Notwit ing, it is dge of $n$ 1 quality kils.

From t en to the ettivity ar If it is folicit t pon one t that pe and to the pecified th 
lays, during ates the $\mathrm{g}$. io converfé

a to obferr. inscers will firm perfuarefumptiou? irch forth to able to his

refcribes, $h$. of wampun

reat Spirit ted to carry bout to dif brothers is ret covered em."

itives that in h with whou I have there h to furprif their blood and thoul III not be for recompens this, be las. t up declare be feceond fome ditin imber of $h^{2}$

will eat th the threat i ellion. No arts of thot bravado, heir reveng
Jet they are not naturally anthropophagi, nor ever feed an the fleth of $\mathrm{men}$

The chief is now wafhed from his fable covering, an. ointed with bears fut, and painted with their red paint. in fuch figures as will make him appear molt terribleits lis enemies. He then Ifings the trat fong, and enume Thites his warlike adions. Having dote this he fixes his gres spon the fun, and pays his adorations to the Great spitit, in which he is accompanied by all the warhiors.

This ceremony is followed with dances, fuch as I have before deferibed; and the whole concludes with a (Aif which ufually confifts of dog's fle?h

This fealt is held in the hut or tent of the chief warfior, to which all thofe who intend to accompany him in his expedition fend their difhes to be filled, and during the feaft, notwithltanding the has falled follong, he fito compnfedly with his pipe in his mouth, and recounts the valorsus deeds of his fanily.

As the hopes of having thrir wound', thould they receive any, properly treated, atid expeditiouny cured, mult be fome additional inducement to the warriors to expofe itemfelves more freely to danget, the prielis, who are 46 their doctors, prepare fuch medicines as will prove afficasions With great cereinony they carry vativus roots and plants, arid pretend that they impart to them the power of healing.

Notwithftanding this fupernitious method of procce. ing, it is vily certain that they have acquired a knowl, dge of many plants and herbs that are of a medicin. 1 quality, and which they know how to ufe with great arill:

From the time the refolution of er.gaging in a war is $\mathrm{fa}$. ken to the departure of the warriors the nights are fpent in feftivity and thedays in making the needful preparations If it is thought neceffary by the nation going to wat. 0 folicit the alliance of any neighboring cribe, they fix ppon one of their chiefs who fpeaks the fame language of that people well, and who is a good orator, and and to them by him a belt of wampum, on which is pecilied the purport of the embaffy in tigures that ey. 
cry nation is acquainted with. At the tou the he carries witb him a hatchet printed red.

As foon as he reaches the camp or village to which Ive is deltined, he acquaints the chiet of the tribe with the general tennor of his commifliour, who inmediately affembles a coubcil, to which the enbaffador is invited: There having laid the hatchet on the ground he holds the belt in his hand ald enters more minutely into the occafion of his embally. In his fpeech he invites them to take up the butchet, and as foor as he has finithed fpeaking delivers the bele.

If his tearers are inclined to become auxiliaries to his nation, a chief Ateps for ward and takes up the hatch. ct,and they immediately efpolife with fpirit the caufo they lave thus engaged to fupport. But if on this ap. plication neither the beli or hitcher are accepted, the eniffary concludes that the people whofe afftance he folicits have alreddy entered into an alliknce with the foes of his nation, ind returns with foegd to inform his coun. trymeh of bis ill fuccess.

The maniner in which the Indiuns declare war againh eacli other, is by fending a lave vith a hatchet, the handle of which is painted red, to the nition which they intend to break with; and the meftenger, notwith. Randing the danger to which he is expofid from the fudden fui $y$ of thofe whom he thus fers at defiagce, ex. ecutes his cominiffion with great fodelity.

Sometimes this toked of defance bas futh in inflantaneous effect on thofe to whon it is prefented, that in the fint tranfpoiss of their tury a rmall party will iffue forth, without waiting for the permifion of the cldest chiefs, and daying the firt of the ofending nation they meet cur open the body and fick a batchet of the furne kind as that they bave just teceived, into the beart of their flauglutes foe $A$ mong the more remote tribes this is done with ari arrow or fpear, the end of which is paintedired. And the more to exalperate, they difmem ber the body, tollow they elteem them not as men, bu as old viomien.

Ibe Indian feldom take the fiedd in lat ge bodies, a fuch rumbers would jeguire a greater degree of induf

oftation Atchis giflites:

inglytir bilitary atrity s from the the grimi When no nppie little pre viatrioins Git of t ब to $\mathrm{al}$ we, are lour tip hivey ind bein de'cater confideno they alw that thes teep vert "'théfe but whic Navidow in Asins they bay i a fier ple Eant tonget li any long fpeak of to eacho

they cade. Teconnoi during $x$ the intell The a ut Wisiol 
10 whe he

to which tribe with amediately is invited. he holds into the ivites them as finithed

siliaries ta the hatch. the caufe on this ap. ted, the en. nce bie folith the foes m his coun.

war againk. vatchet, the tion which er, notwith. $d$ from the efiance, exs

h in inflas. ed, that in y will iffue ff the cides nation they of the farme he beart of inote tribes of which ws her difmem as men, but se bodies, $x$ ee of induff in ta provide for their Yublifence during their tedious atehes through the dreary forells, or Long yoy tges ov. GItites and rivera, than they would care to beftow:

itichir airmies are never encumbered with baggage or Gilitary Ttóres, Zach Warrior, befides his weapons, Write with him' onil $y$ ' mat, and whilt at a diftance from the frontiers of his teiemy fupports himfelf with the gime he 'kinls ir the fith he catches.

When they pars through a couritry where they have no xpprehtrifiofis of theeting with anenemy, they ufe very litt e precaution, fonctines chere are fearcely a dozen witriors left together the relt being dilperfed in purfuit of their game i but though they thould have rov. A to a vety confiderable diftance from the war path, the, are nire :o arrive at the place of rendevours by the Lbur uppóinted.

W. The y halwiys pitch their tents long before fin fet; ind being haturally prefumptuous, they take very lit. We cate to fuard againd a furprife. They place great confidenese in their Manitous, or hourtehold gods. which they alwhys eatry with them; and being perfuaded that they take ypon them the iffice of ceritinels, they Geep very lectrety under their prótection.

"I'hefe Manilous, as they are called by fome nations, but which are terthed Wakons, that is fpists, by the Naudowegles, are nothing more than the otter or martin fins I have already derctibed, tot which however, they have a g teat veneration.

Afier they have entered the enems's country ino pin. ple cin be more cativius and circumber, hies are no long er lighted, no more thouting is heard, nor the game any longer purfued. They ze not even permitted to Speak \& but nutli convey whaterer they have to injuart to each other by figns and motions.

They now proceed wholly by ftratagern and ambuf. cade. Having aifcovered their enemies, they fend to Teconnoitre them, and a council is immedilitely held, during which they fpeak only in whilpers to conflder the inteligence imparted by thofe who were fent out.

The attack is generally made jult before day break, at watel period they fuppofe their foes to be in the 
Coundef Aeep. Throughout the whole of the preceding tight they will lie flat on their faces, without ftirring; and make their, approaches in the fane polture, creep. ing upon their hands and feet till ther, are, got within bowhot of thof they havedefined to deflyction. $O_{n}$ a fignal given by the chief wartior, fowh ich the whole. body makes anfwer by the mof hidepus yell, they all fart up,and difcharging their arraws in the fame initant without giving their adverfaries time to recover from the confulion into which the 25 sthrown, pour in upon them with their war clubs or tomahayks.

The Indians think there is little glory to be acquired from attacking their gpenules openty in the field their greatelt pride is to furprife and deftroy. They feldom engage without a manifeft appearance of advantage. If they find the enemy on their guard, toof frongly en. trenched or fuperint in numbers, they tetity provided they have an opportunity of doing fo. And they es. teem it the the greatelt qualification of a chief inaryor, to be able to marage an attack, fo os deftroy as manj of the enem as poitible, nt tho expenfe of a few men.

Sometimes they, fecure tieprehes tehipd trees, hil: locks, or ftones, and having given one on two rounds, re. tire beiore they are difcovered 'Europeans, who are ungcquainted with this method of fighting too often find to their colt the deftructive afficasy of it:

General Braddock was one of this unhappy number. Marching in the year 1755 ,to attack, fort pu Quefne, he was intercepted by a party of : French aad coufcuerate Indians in their intereft, who by this infiduous method of engaging found means to defeat his army, which cons. fifted of about two thoufand brave frell difciplined troops. So fecurely were the Indians polted, that the Englith fcarcely know from whence or by whom they were annoyed During the whole of the engagement the latter had fcarcely a fight of an enemy 3 and were obliged to retreat without the fatisfaction of being able to take the lealt degree of revenge for the havoc made among them. The Gene al paid for his temerity with his life, and was accompanied in bis full bj $A$ grept nym.

ber of $b$ onty tw When and are. lepene of. hrage fi it the $\mathrm{co}$ pect hou intse of fides: 1 black an Arin, the to be con delantic. I bave bore a pa horror of ing able ? Aancerof and enas brutal fie ed or oye Asad in the yen pear forei Arve ta $g$ diis peop gizing at and those able.

Genera in North of ward Her Mons. lawards fo out fiftes Provincial rent as The ap thout fo ain lake 
preceding, Afrring) ure, creep. at within gion $\mathrm{O}_{\mathrm{n}}$ the whole. it they all me inltant aver from ur in upon

acquired eld, their ier feldom dvantage. ongly en. inprovided 1. they es. ef vearrior, as many of a few

trees, Kil rounds, 1 e. who are often find

y. number. Quefine, he confederate us method which cons difciplined if that the hom they igagement and were being able voc made crity with reat nym: bar of hrave fellows o whilt his inyincite enemies had only two or three of their number wounded.

When the Indians fucced in their filent approaches, and are able to force the camp which they attack, $n$ leene of horror that exceeds defcription, enfues. Tlie irage fierceners of the conquerors, and the defperation the conquered, who well know what thay haye to ex. pet hould they fall alive inco the hanis of their affaitints ofsafion the inol fxtuardinary exertions on both fides: the butre of the fombatants all befmeared with black and red pain and covered with the bigod of the din, their horid y, elly and ungopernable fury are no: to be conceived by thole wha have never croffed the delantic.

I have frequently been a fpectator of them, and once bore a pat in 9 milar icere. But what added to the horror of it ness that I had nos the confolation of be. ing able to oppofe their ravage auacks Every circum. Gance of the adventure ltill dwells on my remembrance, and epables to tascribe vith greater perfpicuity the brutal fercents of the Indiags when they have furprif: ed or overpowered a enemy

As a decell of the maftacre at fort William Henry, in the year 1757 , the lcene to which I refer, cannot ap. pear foreign to the defign of this publication, but will Grve ta give my readers a jufl idea of the fetocity of this people, I Thall take the liberty to infert it, apolo. gizing at the fame time tor the length of the digreffion, and thofe egotilms which the relation renders unaroid. able.

Goneral Webh, who commanded the Englith army in North A merica, which was tipn etacamped at fort Uduard having intellivence that the French troops undet Monf Montcalm were miking fome movements avards fort Willigm Henry, ne detached a corps of acout fifteen hundred men, contilting of Englifh and Provincials, to Atrengthen the garrifon. In this parts went as volunteer among the latter.

The ipprehenfions of the Englifh General were not Thout fcundatioh for the day after our arrival we. an lake Cegrge (formerly lake Sacrament) to which 
it liss contiguch, covered with sn immente numbet of bouts ; ind in a few hours we found oul lines attacked to The French general, who had juft tanded with elev. on thourdind Regulars and Catadians, and two thoufand Indians. Colonel Mono, a brate oftece, com. manded th the fort, ahd had bo mote than ewo thou.

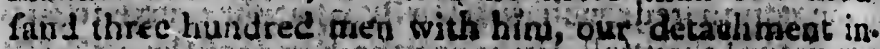
clused.

With thefe he onade gallat tefence, thit probably would have been able at lat to preferve the fort, had he been properly fupported, aid permitied to continue his effo: ts. On every fomons to lifipender lent by the Fench general, who offered the noithonorable terms, his anfwer repeutedly was. That he yet found hinfelf in a condition to repel the molt vigorous attacks his be.

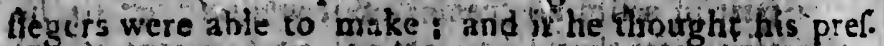
ent for ce inflaficient the could foon be fupplied with a greater number from the dojacent army?

But the colonel having acquainted general Webb with his lituation and defired be woufd fend hitn forme freih troops, the general difpatched a méfenght to him with a letier, wherein he informed him that it was not in his powet to aftilt him, and therefure gave him or. ders to furrender up the fort on the beft terms tie could procun - i his packer fell into the hands of the French general, who immediately femt a fag of trucs, defiring a conference wilh the governor.

They accordingly met, atended baly by a fmall gusid in the centre bet weet the tines; when Monf Montcaln rold the colonel, that he was come in purfon to demand poffelfion of the fort, as 'it belunged to the'king his 'maf. te. "The colonel replied, that he knew nint lfolo that could be, nor fhould he furrender it wp whilk it to as ia bis power to defend it:

The Frencligeneral rejoined, at the fame ctime deliv ering the packet ir.to the colonel's hand, "Ny this ats thority do I make the requifition." l'he brive gover nor had no fooner read the contents of it, and wat convinced that fuch were the orders of the commande in chief, and liot to le difobeyed, than the hung his hea in fiknoo, and relustants entered into a negociation.

In col had may the honc to tranf guaid to the $n$ dij brok iso thou drawn uJ ing on, about, as that this ceéd witl potiver to we weite not allow bopes ho fome of when fic notirithift their ener putched. Here n: rouid li:2 move: $b$ driven bin circled by that the : pitulation and put cearça. Fithout $\mathrm{e}$ tho mad comahaw

1 happ ang befo or four of seld their de of my ot to tal. hiv was $t$ 
iunthel of s atticked with telev. two thou iet com. exo thina. thinent in. 1

jtorobably fort, had d continue ent by the able terms, and hingelf acks his be. he hits pre?. ied with a

eral Webb thim forme iger to him titi was not ive him or: mis tie could thie French $\therefore$ defiring

Imall gusrd 1. Montcalma 12 to demand ing his mar. iot Kofot that Ift it tras ia e time delive - Hy this aur. brive gover. it, and was commander ung his hea gociation
In confideration of the gallant defence the garrifon Jad male. they were permitted to march out with all the honors ot war, to be alicwed covered waggons ip tranfpost thetr biggage to fori Edward, and a Guard to proted them from the fury of the ravages.

the morning after the cupitulation was figned, as day broke, the whole garrilon, now confilting of about iso thourand men, befides women and children, were drawn up within the lines, and on the print of marching off when great numbers of the Indians gathered about, arid began to plunder. We were at firlt in hopes. that this was their only view, and fuffered theth to pro. ceed without oppolition. Indeed it was not in out potver to make any, had we been fo inclined, for though we were permitted to catry off our arms, yet wh were not allowed a fingle round of ammunition. In thefe hopes howezer we were difappunted; for prefentiy fome of them began ti) attack the fick and wounded, when fich as rere not aule to crawl into the ranks; not citifftanding ilies endeavored to avert the fury of their enemies by their hisieks or groans, were fuon difi patched:

Here sie were fully in expecation that the difturbance rouid hirye concluded, and our little army began to. move , but is a thort time we faw the front divifion driven back, and difcovered that we were entirely encircled by the fivages. We expested every noment that the guard, which the French by the arficia of ca. gitulation, has agreed to allow us, would have arrived. and put dit end to our apprehentions, but none ap peared. The Indians now began to ftrip every oue without exception of their arms alid clotics, anit thofe who made the leaft reffitance felt the wieight of theis comahawks:

I happened to be in the rear divifion, lut it was not lang before I hiared the fate of my companions. I'liree or four of the favages laid hold of me. and whilt fome held their vieapons over my liead, the others difrubed. he of my coat, "wailfcoat, hat, and bucklis, umitting ot to take from me what money I had in pocket. As his was tranfacted clofe by the partage that led from 
the lines on to the plain, near, which a French centinel was polted I tan to him ana claimed his protection; but he only called me an Englith dog, and thruft me with violence back agrio into the midet of the Indians.

I now endeavored to jain a body of our troops that were crowded rogethet at fome diftance , but innume: able were the blows that were made at me, with differ. ent weapons as I paffed on luckily, however, the fav. ages were fo clofe together, that they could not Arike at me without endangering opch other. Notwithltand. ing which one of chem found méans to make a thruft at me with 2 fpear, which grazed $m y$ fide, and from angther I received a woind, with the fume kind of wea. pon, in my ankle As length I gained the fpot where my country mon Atood, and forced my felf inte the midit of them. But before I got thus far out of the hands of the Indians, the collar and wriftbands of my thirt were all that remained of it, and my flefh was fcratch. ed and torn in many, places by their favage gripes.

By this time the war whonp was given, and the In. dians began to murder thote that were neareft to them without diftinction. It is not in the powes of words to give any tolerable ides of the horrid fcene that now en. fued, men, women, and children were difpatched in the moft wanton and cruel manner, and immediately fcalped Many of thefe favages drank the blood of their victims, as it flowed warta from the fatal wound.

Wo now perceived, though too late to avail us, that we were in expeq no relief from the French; and that contrary to the agreement they had folately figned to allow us a fufficient force to protec us from thele in. fults ther tacitly permitted them for I could plainly perseive the French officers walking about at fome dif. tance, difcourfing together with apparent unioncern. For the ponor of human nature. I would liuge that this fiagrant breach of every facred law, proceeded raiher from the favage difpofition of the $\mathrm{f}$, ns, which I nc. knowledge it is fometimes almos inpoltible to contronl, and which might now unexpeededly have arrived to $a$ pitch not eafily to be reflained, thin to any premediti. ced defign in the French commander. An unprejudic.

ablet body of troops, ] from bi caule fri treadful As th was mu ing with molt rê or to for able met This, ho tirenty 0

In an the fate fonths a them effe irdous fit my tavag I have of lected wi ellay ftep baing at ad by two rery. coutd dil cot refilt, force me I now re they inte vengeanc ing me tance. I gentlema his breech ot Gne 1 the India gon thi prey's bu the groun 
h centinel rotection; hruft me Indians. oops that innumet: ith differ. r, the fav. ot Arike rithiftand. e a thruft ind from id of wea. pot where the $m$ idit the hands. $f$ my thist s fciatch. ripes.

id the In. it to them $f$ words to at now en. patched in imediatels blood of al wound. il us, that and that figned to a thele in uld plainly t fome dif. unconcern. pe that this eded raiher thich I nc. to contronl, rrived to a premeditil. unprejudic. cad obferver would, however be apt to enonclude, that 2 body of ten thourand chriftian truops. moft chrittian troops, had it in their powier to prevent the maftacre from becoming fo $g$ eneral. But whatever was the cale from which it arole. the contequences of it were dreadful, and not to be paralleled in modern hiltory.

As the circle in which I'food encloled by this time was much thinned, and deatt feetred to be approach. ing with halty ftrides it was propofed by fome of the moft refolute to miake one vigorous effort, and endedv. or to force our way through the favages, the only prob. able method of preferving our lives that now remained. This, however defperate, was refolved on, and about thenty of us fprung at once into the midat of them.

In a moment we were all feparated, and what was Whe fate of $\mathrm{m} y$ companion $I$ could not learn till fome wonths after, when I found that only fix or leven of them effeded their defign. Intent only on my own haz. irdous fituatio in I endeavored to make $m y$ way through in Iavage enemies in the béf manner poffible. Arid I have often been aftonithed fince, when I have recollected with what compofure I took, as I did, every nec. eflay ftep for my prefervation Some I overturned, being at that time young and athlétic, and others $t$ paf Gd by, dextroully avoiding their weapon's, till at laft two yery ftout chiefs of the mont favage trivs, as I could dittinguith by their drels, whole trength $I$ could uor refit, laid hold of me br each arm, and began tu force me through the crowd.

Inow refigned myfelf to my fute, not doubting but that they intended to difpatch me, and then to fatizte ineir Vengeance with my blood, as I found they were hurrs. ing me cowards a retired fwamp that lay at fome dir. tince. But before we had got many yards, an Englih gentleman of fome diftínetion, as f conld difcover by his breeches, the only covering he had on, which were of fine fcarlet velvet, ruked clofe by lis, One of the Indiars inftantly relinguifhed his roil, and fpring. ingon this new nbject, endeavored to feize him as his prey; but the gentleman baing Atrong, thre him on the ground, and would probably have got away, bad 
nat he who held my other arm, quitted me to affit his brother 1 tized the opporeunit $\mathrm{x}$, nus haftened away to join another perty of Englith uoops that were yet unbrol $n$, and hood in a body at fome diftance. But before I had taken many feps, I hastily caft my eye towards the gentleman, and faw the Indian's tomahaw $k$ gall into his back and heard him witler his lalt groto this added both to my fpeed and déperation.

I had teft this focting fcene bul a few yards, when a fine boy about twelie, years of age, that had hitherto etcaped came up 80 me, and begged that I would let him thy hold of me fo that he might Aard fome chance of geting ont of the hands of the favage. I told him that I would give him every afiftance in my power, and to this purpole bid him lay hold but in 2 few mo. ments he was torn froth hy flde and by his Thrieks I judge was foon demollithed I could not halp forget. ting my own cares for 2 minute, to lament the fate of to young a fufferer, but it was utterly lmpolible for me to take any any methods to prevent ic.

I now got ofice more into the midlt of friends, but we vere unable to afford each other an y Juccor. As this was the divilion that had advanced the furtheft from the fort, $f$ thought thete might be a pothibility (tholtghibut a bare one) of my forcing my way through the out tranks of the Indians, and getting to a neigh. boting woad, which I perceived at fome diftance. I was till encouraged to tope by the almoft mitaculons prefervation I had already experienced.

Nor were my hopes in rain, or the efforts I made ineffectual Suffice it io fay, that I reached the wood; but by the time I had penetrated a litile way into it, my bre th wh fo exhanited, that I threw mytelf into a brake, arid (a) for fome minutes apparently at the lat gap. Atlength I recovered the power of rifpira tion , but my apprehenfions returned with all their former force, when I faw feveral favages pals by, prob. ably in parfuit of me, at no very great diffence In this fituation I knew not wherher it was better to proo ced or endegror to conceal myfelf where 1 Ly, till 
to affift his ened away it were yet ince. But astily caft law the heard him fpeed and

ards, when ad hitherto I would let ome chance I told him my power, L 2 few mo. Thrieks I halp forget. the fate of polible for

friends, but uecor. As he furthet poffibility ay thiough a neigh. iiftance. mitaculous

I made in. the wood; iy into it, ytelf into $a$ at the lat of rifpira. $1 \mathrm{-all}$ their sty, prob: isnce In ier to proo 1 isy, till

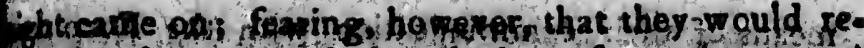

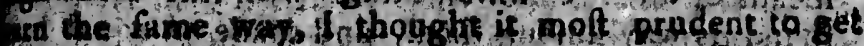

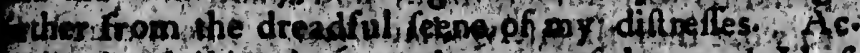

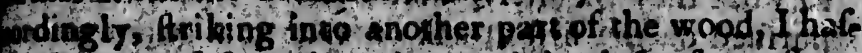

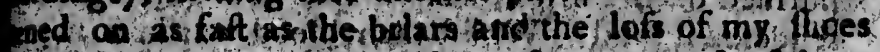

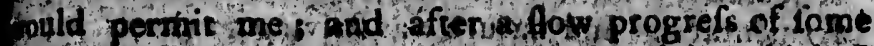

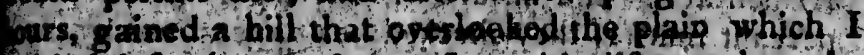
djufleft, from shence I tould difcem that the lood stor to fitl raged whith und thated fury,

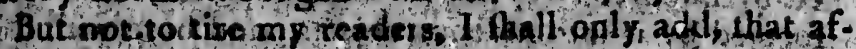

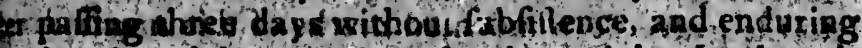
The feverity of the cold dews for thiee nights, at length

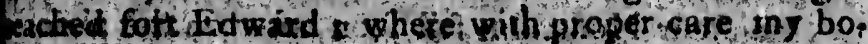
W foon recovered its wonted Arength, and my mind, far as the tecollegtion of llie lase melzacholy re rehts iould permit, its ufualicempofinte:

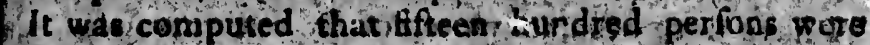
tilled orunade prifoners by thefe lavages duripg this fital diy Many of the latter werd carried of by them and neven returded i few, through favorable acciImts, found their wat back to their vative caunery af whaving experiencud tong und fevere saptivity

The brave colonel Murco sad hiftened a why foon afo w the confution began, toube French camp to epdeay. or to pracurs the guard agreed by the Atipulation; but Wis applisation proving ineffectual the remained there Gill generall Webly fent a party of tronps to demand and motide thim biok to fort Edward. is thefe unhappy toncurrences which would probably lia ie been preventd, had the been teft to purfue his own plans, rogether With the loft of fo many brate fellows, thurdexed in cold blood, to whofe valor he had been fo littely a witnofs, trade hish an impreflion on his thind that he did nce long sir wize. He died in a bout three months of 2 brok. wi heant, rand with truth might it be faid, tat he was in horrot to his coabtry?

17 thean not to point cont the following icircumftance the immediate judgmeit of heaven, and interided,as matonenient for this naughien ; but I cannot omit that hery few of thofe different tribes of Indians that tiared

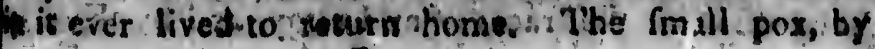
Q 
- Dearf of their cobinatication - wich the Juro pe found if tar amons thin, and thade an equal ba to whin the the mel wh had does. IT The methods $t^{2}$ verifed on the fith attack of thet maliganent diford rendered it fatal Whilk thir blood was in a iftate? ferpentution, and tature was fuiving to throw out pecent whiter, the $y$ dicted her opperations by plun ing into the vaton the confequence was that they ed by hupdreds the few that forvived were tre for hed th it into hideous objects and bore with the to the grave depp indented marks of this mueb drew ad difeafe.

Monfieur Montcalm fell, 800 after on the plains o Quebec.

That the unpropoled eruelty of this commander not appioved of by the generality of his cubatrym. I have fince been contineed of by many proofs. $U$. only Whwever, which I teceived from 4 perfon who w witnefs to it thall I at prefent gire. A Cansedian me chant, of fome confideration, haring heard of the Fender wi the Englifi fort, celebrated the fortunate vent with great tejoicings and loorpitality according the enflom of the pcountry i-but inn fooner did the sneof the mafficre which enfued seach his ears than put an immediate fiop to his feftivity, and tezd aime in the fevereff terms ogainit the inhuman petimifion declaring at the fame time that thofe who had conni ed at it, had thereby drayrn down, on that part of the King's dominions the rengrance of Heagen. Io the seiauded, that he much feared the toral lofs of ther would defervedls be the confequence. How truly th predietion las been resiged we well knpw.

Bit to verurn -though the Indiand are negligent guarding againft furprifes, they are alext and dextrou in furprifing their enemies. Tio their caution and pef feverance in fevaling on the party abey defign to attad they add that admizable talent of rather inftinati qualitication I have dlready deferibed, of tracing o thofe they are in parfuit of. On thic fmoothat graf ons the hardeft exath, and even on the very flones, w they difcover the tracces of an enemgri and by ithe the

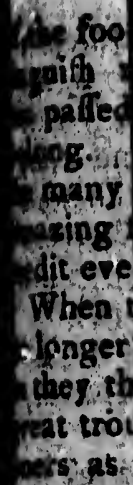

troire e Tith thet At thi: tive the one 0 the hai hat cove alping or this $\mathrm{c}$ ite off $x$ upeditio carcelye wents $c$ woofs of emies.

intwo ad feem an is tifpute. Chall courfe to had the Havir tavoc a - orn coll ot being Shoul ageme 4 omectip 
16 Juro po in equal ba imethods th seant diford 1 in a ftate? throw out? ioas by plun s that they d were trat ore with thet much dread

ithe plains ummander covutry me proofs: 0 erfor ho w anadian mee $d$ of the fin c fortunate eccording aid the ner aers than nd perdaime n permition. had connie 1 part of the ien. Tot th 1 lofs of the low truly th

- negligenti and dextrou tion and pet igs co attac ex inflingtir f trecing o. cotheltigraf y flones, w? by ithe the
The foorteps, and the diflance betiogen the prints dif With not only whether it is a man or woman who Paffed that way, but eren the natiog to which they Hog Howergr incredible his may appear, yet froth An ins proofs I received thilt ationg them of their Haing fegaity on this point, I fee no reafou to dif. dit even thele extraordinary exertions of it

When they have orercome an enemy, and riaor is Vonger'doubiful, the conquerors firf difpatah all fuch the think thon thall not be able to garry off withopt. that trouble, and then endeavor to take as many prif afs as poffible, after this they neturn to fcalp thofe to afe either dead or too much wounded to be taken ith thion.

At this bufinels the are exceedingly expert. They The the head of the difatled or dead enemy, and plac. one of their feet on the neck twith their left hand the hair, by Nis theans, having extended the Hin. hat covers the top of the head, they dra w out their Wling knives, which ase ol was kept in good order or this cruel purport, and wilh a few dextrous froket the of the part that in termed the fcalp. Thes are fo apeditious in doing this; that the whole time required curcely exceeds a minuce. the efe the 7 freferve as mon. mente of their prower, and at the fame, time as poof of the rengernce the linve infliced on their en. emies.

Ift and feem to have an equal claim, the contel belween wan is foon decided, for to put a fpeedy etrd to any Hifpute that might arifo, the perfon that is apprelienfive be (hall lore his expected reward, inmediately has re. gourfe to his tomahaw' of war club, and knocks on the had the unhappy caufe of their contention.

Having completed their purpofes, and made as much Hovoc as polfible, they inmedistely fetire tuwards their ornq country, with the fpoil they have acquired, for fear ateing parfued.

Should tius be the Gafe, they make ufe of many Atrat. ageme to elnde the farches of their porfuerd they pometimes featur leaves fand, or due over the prialo 


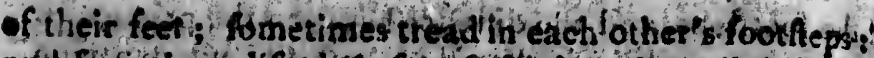

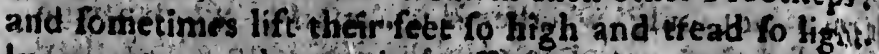
Iy, as not to make ant impreflien ob the ground Bus

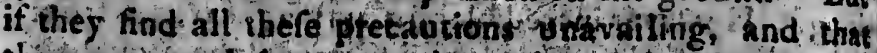
they are near being overtaken, hey hro offpatch and fealp tiveir proforets, and then atividing, each endegivor to regain his native country by a diffexent toute. Ihis prevents all further purfuil w for their puifaers now defpaining cither of gratifyting their revenge $\mathrm{rr}$ of $\mathrm{re}$ leafing thofe of theirifrictid's who wete trade captives, return home.

If bliefuccefsful party $1 \mathrm{~s}$ folucks as to thake good

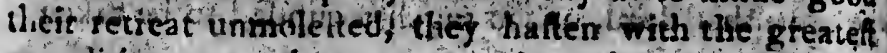
cxpedition to reach a country where they mat be per. fectly fecure gathd that thet uounded companion may

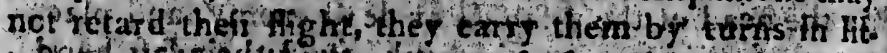

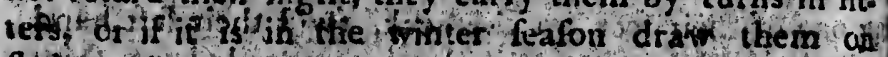
nddges.

iheir fitters dre made in a rude manner of the brand ches of tha tites "rkaith lges confilt of two fmall Ufin bostrof abolt a foot wide when joinct, and rear, fitfet ing. $1 \mathrm{be}$ tore part is tarned ap and the fides

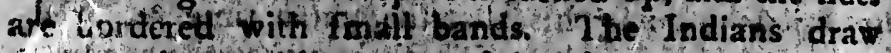

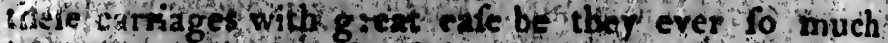
lorded by meants of a fring which pafes round the britite. Ihis collhtis called Mettmpignd is in ufe throughout America, bath in the fettlements and the in terial payts. Thofe offed inthelater are made of teath. er, and very curiobny wrought

I he pritoners duting thert march are gubfed s with the grehtelt care. tourng the day, if the jourdey is overluth, they ated alwas held by fome of the victorious party if by water, they are taftene to the chnde. In tie night clime they are ftretched along the grourid quith fraked, with their Iegs, armis, and ned fallented to hobk $6 \mathrm{ed}^{\mathrm{f}}$ the ground Befides this, cords ate tied to theiturth of Jegs, which are held bf an Indist, wha inftantly awakes at the leat motion of thetu?

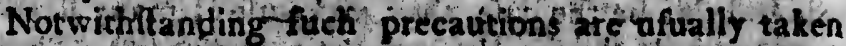

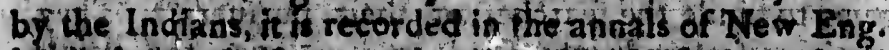

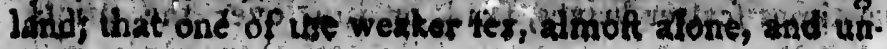




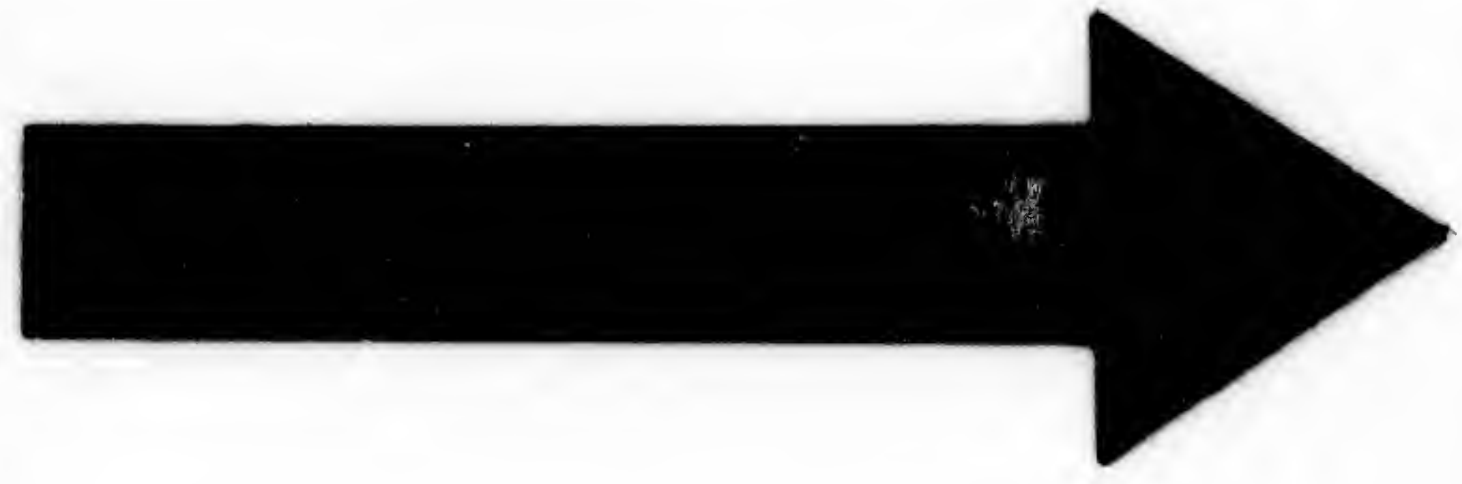


IMAGE EVALUATION

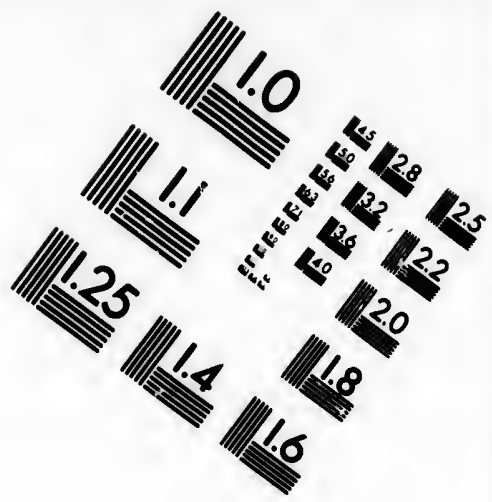

TEST TARGET (MT-3)
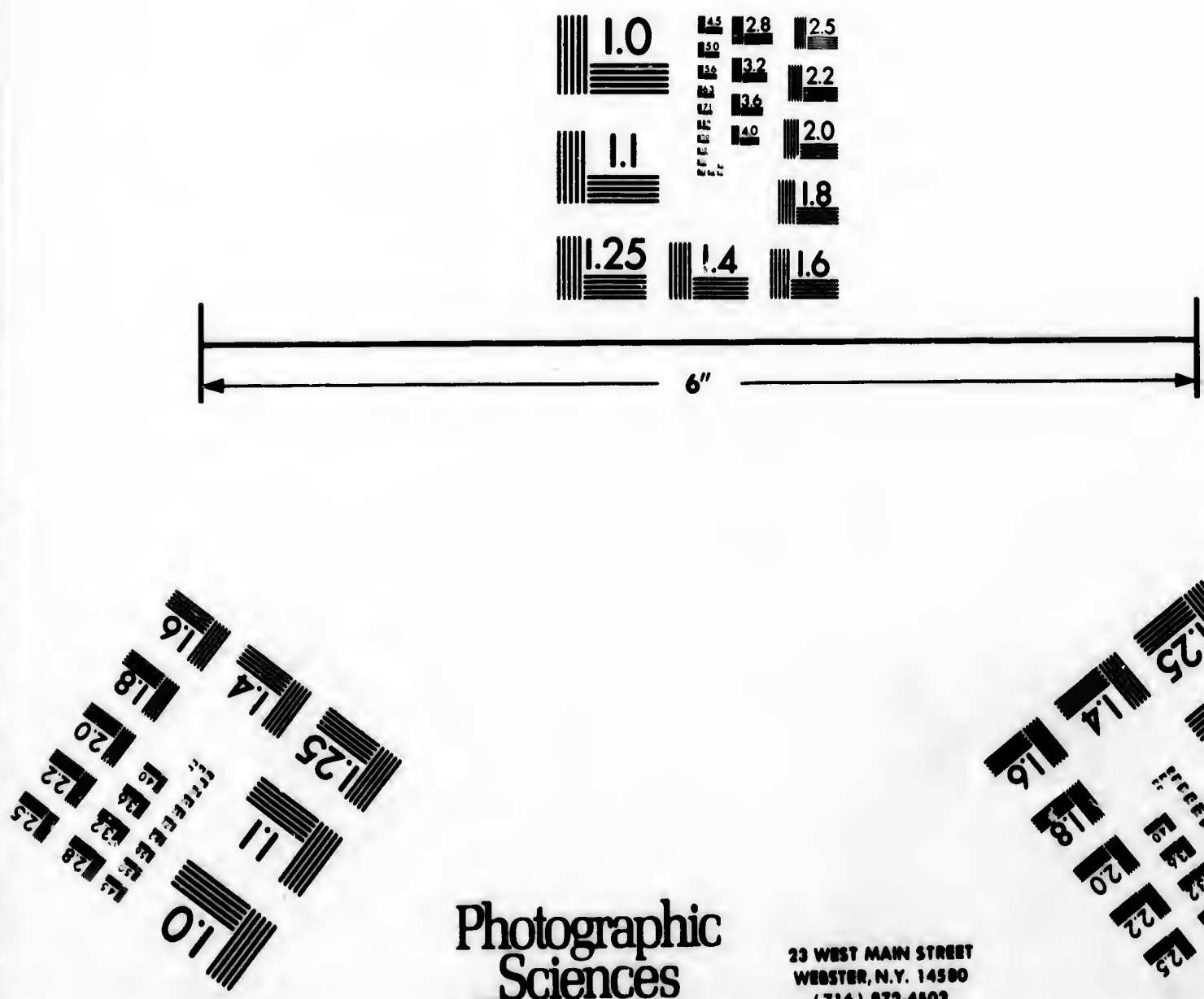

Photographic Sciences

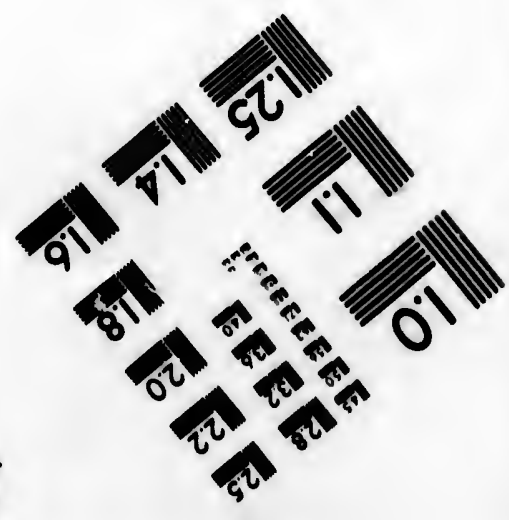
Corporation 

ed onemies, and feizing alfo thofe they were carrying a. way with them as proofs of their fuccefs, the returned in triumph to the town from wheree the had folately been dragged, to the attonifiment of all her neighbors, who could tearcelf credit their fentes, or tellimonies the bore of her amazonian intrepidity.

During their march they oblige their prifoners to fing thet death-long, which genterally contifts of thefe or

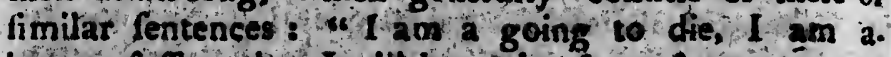
bout to fuffer, but I will bear the feverelt tortures my enemies can infis, with becoming fortitude I will die like a brave man, and I thall go co joid the chiefs that havefiffered onthe fame account Thefe fongs are contintied with the receffary intervals, until they reach the village or camp to which they ate going.

Wtien the warriors are urrived wihn hearing, they fet up different cries, which communicates to their friends a general hiltory of the expedition. Whe number of death cries they give, declare how many of their own juity are loft ; the vumber of war-whoops, the num." ber of prifoners they have takn.

It is diflicult to defcribe these cries, but the belt idea I can conves of them is, that the former confifts of the found whoo, whoo, thoop, which is continued th a long thrill toine, nearly till the breath is etheuled, and then bpoken of with a fudden elevation of the roice. The latter, is a lotd cry, of auch the fane kind, which is modulated into notes by the hand being placed before the mouth. Both of them might be weard to a vary confiderable difánce.

Whilt thefe are uttering, the perfons to whom they are defigned to convey the intelligence, continue mo. fionlers and all attention. When this ceremoty is per. formed, the whole village illue out to tearn the particulars of the relation they have juft heard in general term, and accordingly as the newroprove mouraful or the contrary, they abfwer by fo many acclamations of cries of lamentations.

Being by this time arrived at the village or ctmp, the women and childten arm themfelves with flicks and bledgecns, and form thomlel res info tiro ranks, through

which t they un line, is the hea life; ; a abend tormes give pri bie fuffe Aftei theylari council Trtiol at torm fach as chief ol oners in pronnu ing $\mathrm{COd}$ houfe

Such have ac rays al tures of by the which Europe Thet is by br lints di pine. I are eltee ferve as who" the valor. The place of the fart part of it rea is 6 
c carrying a. the returned rad folately r neighbors; Aimonies the

onets so fing s of thefe or is I an a. tortures my I will die ie chiefs that ofe fongs are il they reach g. tearing, they their friends number of their own , the num.

lie belt idea infifts of the leditn a long df and then roice, The d. which is laced before ato a very whom they intinue mo. noy is perats the par. 1 in general nouraful or imations or

or ctimp; the 1 flicks and aks, through which the prifoners are obliged to pars. The treatment they undergo before they reach the extremity of the hine, is very fevere. Sometimes they are fo betaten over the head and face, ws to tiave fcarcely any remains of Iffe; and happy would it be for ubem if by this urage an end was put to their wretched beings. But thein tormentors take cave that mone of the blows they give prote mortal, as they wifla to teferve the mifere. bie fufferers for more fevere inflietions.

After having undergone this introductory difciplind Licy late bound hand and foot w will the ehiefs bold ta council in which their fase is determined.

Thole who are decreed to be put to death by the ufuat tniments, are del ivered to the chief of the marriorst fach as are to be fpared/ are given into the hands of the chief of the nation I fo that in a thort time all the prifs oners may be affured of their fase, as the fentende tow pronunced is irrecoverable. the fornaer they term be. ing confignied to the houfo of deach, the latter to the Loufe of grace:

Sich captives as are pretty far advaoced in life, and have acquired great honor by their warlike dfeds, tho ways atone for the blood they have fpily by the tor fures of fire t Their fliceefs in was is readily known by the blue marks upon their brealts and arms, which are as legible to the Indianis as letcers are ta Europeane:

The manner in which thefe tiernglyphics wre made. is by brealting the flin with the weth of fifh, or fluar pened hints; dipped in a kiad of ink made of the foot of pitch pine. Lite thole of the zncient piets of Bricain thet are efteemed órnamental and at the frme time diver ferve as regilters of the hernic netions of the wartion. who thos bears about bim indeliable i marks of his valor,

The prifoners deflined to death ase foon led to the place of ezecution, which is generally in the centre of

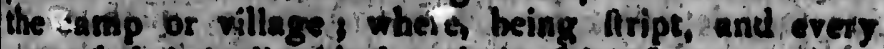

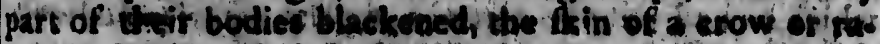

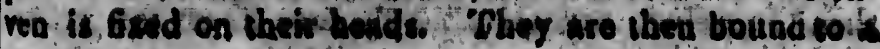


Aake, with faggots heaped around them, and obliged, for the latt time, to fing their death fong.

The warriors, for fuch it is only who commonly fuffer this puriihment, niw perform in a more prolix manner this fad folemnity. They recount with an audible voice all the brave aqtions they have performed, and pride themfelves in the number of exemies they have killed. In this rebearfal they Spare not even their tormentors, but ftrive by every provoking tale they can invent, to irritate and infult them. Sometimes this has the defired effect, and the fufferers are difpatched fooper than they otherwife would have been.

There are many other methods which the Indians make ufe of to put their prifoners to death, but thefe are only occafional ; that of burning is mof generally ufed.

Whila I was at the chief sown of the Ottagaumies, an lllinois Indiau tras brought in, who had been made prifoner by one of their war-parties. I had an oppor. cunity of feeing the cuftomary cruelties in lieted on their captires, through the minateft of their procefs. After the previous fteps neceflary to this condemnation. he was carried, early in the morning, to a little dif. sance from the town where he was bound to a tree.

This being done, all the beys who amounted to a great number, as the place was populous, were permitled to amufe themfelres with thooting their arrows at the unhappy victim. As they were nurie of them more than twelve years old, and were placed at a contidera. ble diflance, they had not frength to penessate to tho vital parts, fo that the poor wrtetch flood pierced with arrow, and fuffering the confequent ag is for mose than two days.

During this time he fung of his war like exploits. He recapitulated every Atratagem he hact made ufe of to Surperife hic enemies i be boafted of the quantiet of fcalpe be poffeffed and enumerated the prifoneis he had taken He then doferibed the different barberow methods by which he had put the better to death, and scomed evee then to receive inconceirable pleafure from the recied of the horrid tale 
nd obliged,

monly fuffer olix manner udible voice. , and pride have killed. tormentors, invent, to irthe defired or than they

the Indians b. but thefo oft generally

Dttagaumies, a been made ad an oppor. incieted on heir procefe. andemination :o a little dic. to a tree. counted to a were permitir. arrows as of them more a conlidera. teste to the pierced with is for mose

like, exploits. nade ufe of to ncies of fcalps be had taken methods by seared erea whe rscitt?

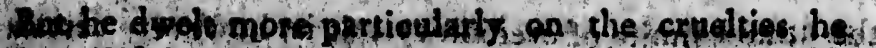

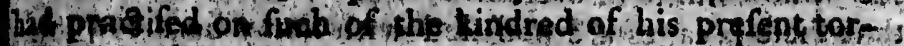

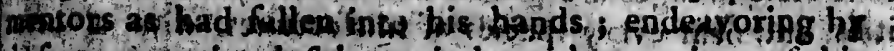

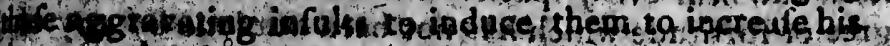

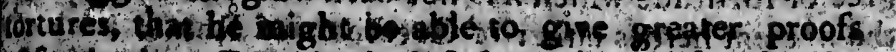

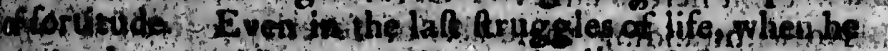

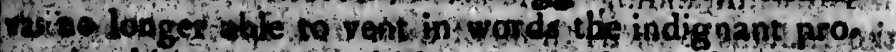

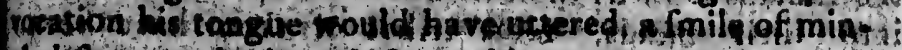

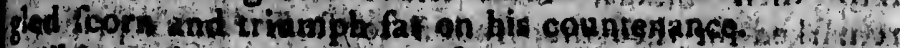

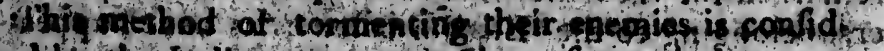

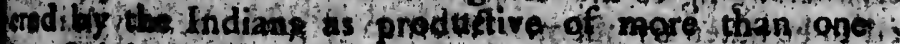

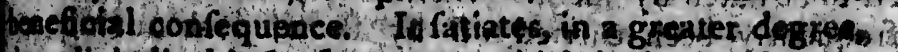

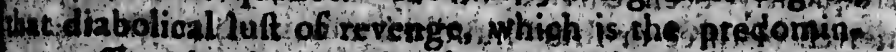

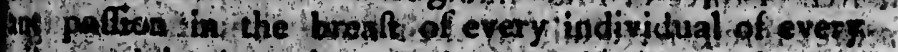

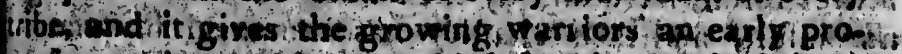

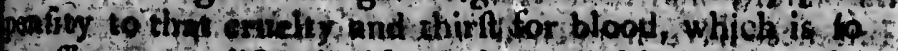

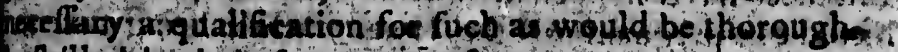

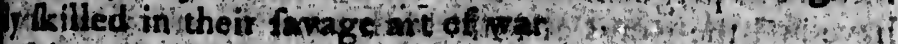
3 have boen ifformed, thas an Indian who way under is frands of his tomenters, had the pudacicy to thell. 15an, that they were ignohine old womep, and did nos thow how to put leave priloners to death it the act gdainted them that he bad heretg fore takdn fome of

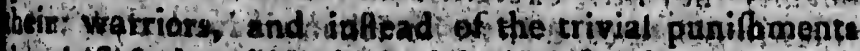

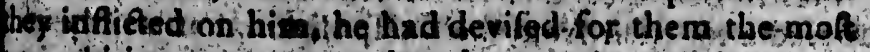

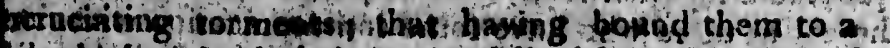

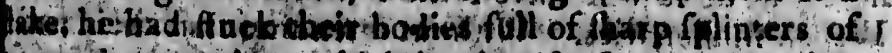

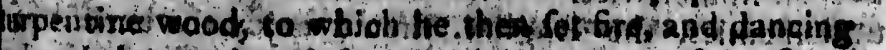

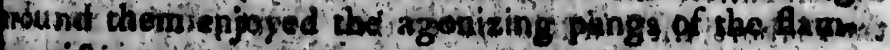

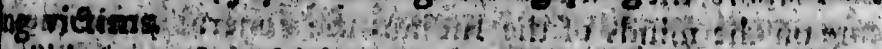

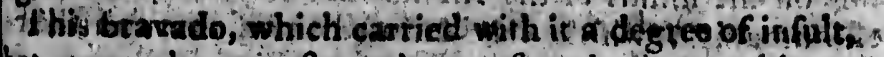
hat even the nocuftemed ear of an I ndian could not

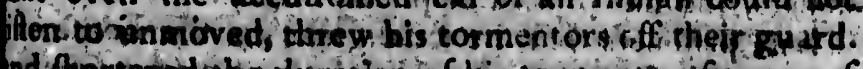

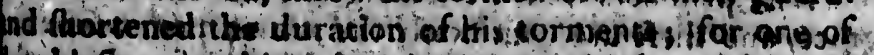

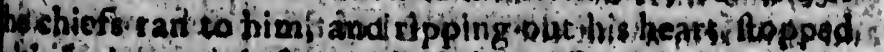

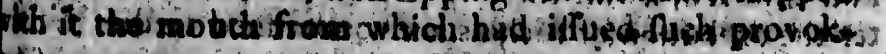
language.

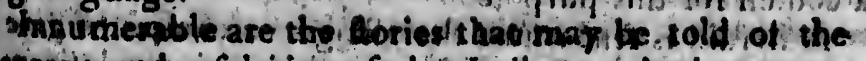

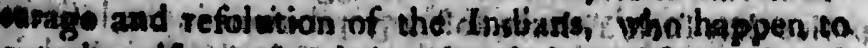

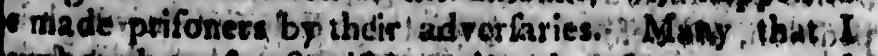

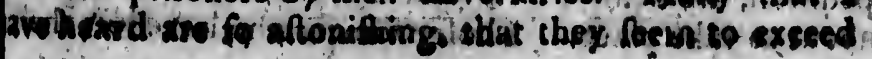




\section{Wo CARTER'S TRAVETE:}

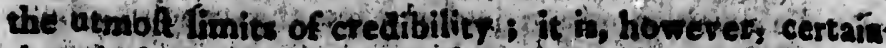

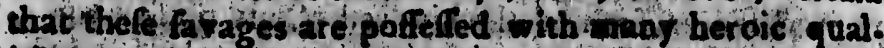

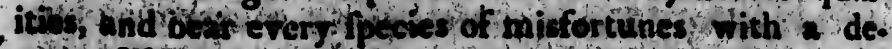

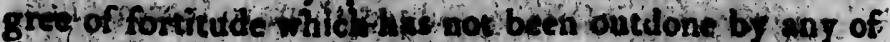

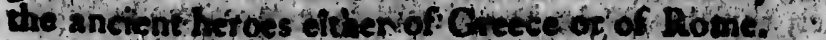

sothidituding towe act of feverity ezercifed by the thatans towares thote of their one pectes, thio fall into te theif hand, sene retitut of them have been

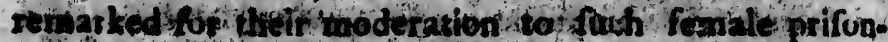
ert betonging to the Staglif colonics as have fiappens ed tobe talien by them Wamen of great bearty have

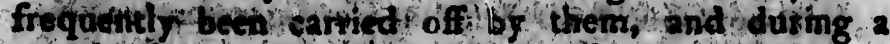

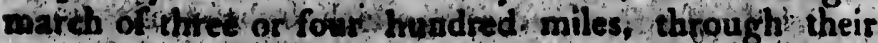
retired fotel, haveltin by theim fides withont receiving: distiffult and their challit has rcmained inxiolate. Inthince hate hippened whete fectale exptives who Iiva been pregtant at the t tme of thetr being taken, have had the pangs of child birth come upon them in the mial of folitar woodh and favefes their odly com.

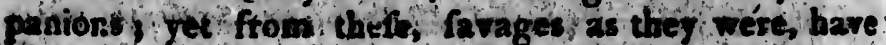
thef received every affiflestes theit fituation would ad. mit of and ven treated with a degred of dulicacy andi bomanits they litule expesed.

This forbeartitice, it thu bo aclenowledged, does not proceed altogether from their difpofition, bnt is only in. herent in thof who have forse downunication with the

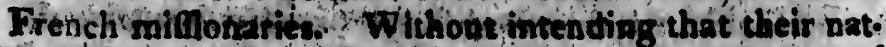

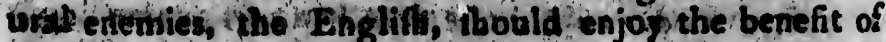

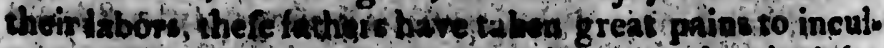
cate ofitle minds of the Ibdians the general principies

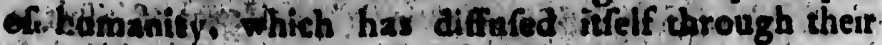
manidts, that has proved of prblic utility.

Thof prifoners that ate configned to the houfe of

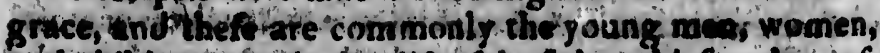
arld children, aw ait tho aifpnfal of the chief, who, af. ter the devertion of fwehias are condempedieo dits hold - coulcil for this purpoife.

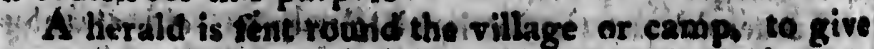
notice that foch'as have Ioft anj relations in the late ex. pédition, ore defired to attend the diltrioution which in

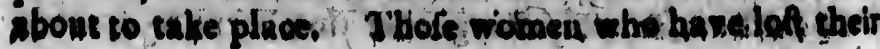

Pings ftest Inore dop

ith gresc in) 0 nobos happe them, ins 5 $\mathrm{Wh}$ op to that as te che nitho tas to cointr If the wis the ene happen flould who t: fracies try of

Whe the de nithou council be enti been ju 1 tho whom eption of fuch and is eigntit then.

The

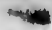


5 certaís. rate quals. ith $a$ de. b) ong of reifed by s, who fall have been Lle prifunYel happens: cavity liave: locuting 2 ough their it receiving 1 inviolate. frives tho ving takes, in them in if oilly com. wére, bave a wovild ad. dilicasy and

edidoes not atis only in. cion with the wit cheir nat: he bentit of hies to inculo. 1) principies rough their.

he houfe of dotis wornien, Sf, who i of. roidid hold

thops te give in the late eso tion thich is rane leff elocir

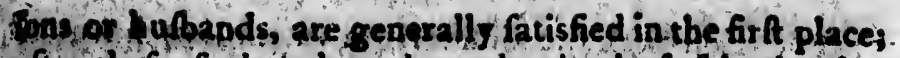
ifte there fuch to hive beet deprived of friends of hore remote dogres of confang winity, or who choofe to Hop lome of the youth.

the divifion being made, which is done, as in ochat If ${ }^{2}$, without the lepit difpuse, thofe who have received in) on .re. lead them to their tonts (x, huts; and having gobound them, rah and drefs their wounds if thes happen to bare received any ther then clothe them, and give them the molt comfortable and refrelb. in food their fore- 1 ill a ford

Whit their nen doneftics are fecding, they endeay. ot to adminiler confoletion to them; they tell them that is they are redeened from death, they mult now te cheerful ond hapy and if her ferxe then well, thous ous muring or ispining, nothing thall be wanttho to muke them luch atonement far the lofs of their oquntry and friends as circumanece will allow of.

If any men are f pued, they are commonly given to the ridows thas bave loit their hulb ands by the hand of the enemy, hould there be any luct, to whom, if the happen to profe agreeable they are foon marived But thould the dame be otherwite engagea, the life of him tho tulls to ter lot is in greac danger; efpecially if the facies that her late hubdnd wants a lure in the coup ity of firitg to which he is gone.

When this is the cafe, a number of young nen tak the devoted captive to fome diftance, and difpatch hir nithout any ceremang a fer be has been fpal ed by the council they copfider him of too little confequerce to be entitied to the torments allotted to thore wio have been judged worthy of them.

Ih women are ufually ditribused to the men, from thom the do not fail of meting rith a tavorable re: ifeption. I he boys and girls are taken int c the families f fuch as have ned of them, and are confidered as Mavea Hd it is not uncommon that the are fold in the fáme

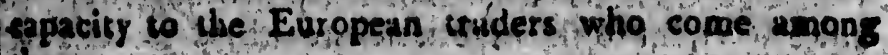
then.

Whe Indians have, idea of moderating the rayag. 7 of rat, by fparing thej prifoners and cutering into 
of riolence, and with anremitted ardor. The prize they fought for being no longer revenge or fame, bit the acquirement of pirituous liquors, for which their cap. ives were to beexchanged, and of which almoft every intion is immoderntely fond, they fought for their enemies with unwonted alacrity, and were conftantly on the watch to furprife and carry them off.

It might' Atill be faid that fewer of the captives are cormented and put to death, fince thefe expectations of receiving fo valuable a confideration for them have been excited than there ufually had been: but it does not appear that their accultemed cruelty to the wattiors they take, is in the leat abated; their natusal vifire of rengeance mult be gratified; they now only becolme more affidnous in fecuring a greater number of joung prifoners, whilt thole who are made captive in their defence, are tormented and put to death as bitore.

The miffionaries findings that contrary to their wilh(t, their zeal had only ferved to increafe the fale of the norious juices/applied to the governor of Canada, in the year 1693, for a prohibition of this baneful trade. An order was iffued accordingly, but it could no put a total fop to it i the French Coui ier de Buis Were hardly enough to carry it on clandeftinely, notwith. ftanding the punalty annexed to a breach of the protib bition was a confiderable fine and imprifonment.

Some who were detected in the proffecution of it, inithdrew into the Indian countries, where thes inter? thetried with the nktives, and underwent 2 voluntory banithment. Thefe hoviever, being an abandoned and debauched fet, their conduel contributed ver? little either to wasds reforming the manneis of their new relations, or engaging them to entertain a fayora. ble opinion of the religion thiey psofeffed. Thus did thefe indefatigablo, religions neo, fee their defigns in fome meafure once more fruftrate.t.

However, the emigration was productive of an effed which turned out to be berieficial to their nation. By the connetion of their refugres with the Irnquois, Mirs

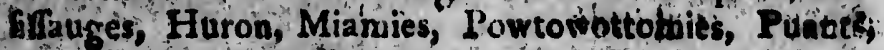
a $\mathrm{K}$ - Pow cripared to 10 s to purchafe

differs not in thon xod which gers or thote contidered as to the Euro. Iuperintent 5 miffionaries zele unhapp by fo doing

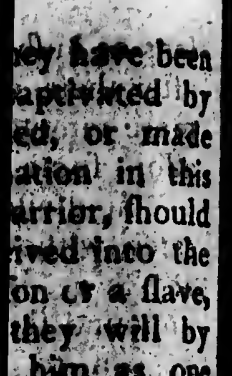

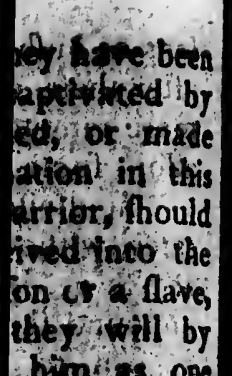
theide tatrents tacotinnor te.

chiests who have been ino mate no dif. efectoy chance ken they are toys atefuliperfons, J. iey ina porturitites of (f) bent he the shret degret .

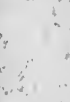
, 
Menomonies, Algonkins, ac. and the conttant repre fentations thefe various nations received from them of the power and grandeur of the French, to the aggrand izerhent of whose monarch, notwithiftanding their bans. itmment, they Atil retain their habitual inclination, the In liens infenfibly projudiced in favor of that people. and I am perfuaded will take every opportunity of thets. ing theit attachmint to them.

And this tien in defpite of the difgraceful eftimation they muft to held by them, fince they have been drit. en out of Canada, for the Indians contider evers con. quered people as in a ftate of valfalage to their conquer. ors. After one nation has finally fubduod another, and - conditional fubmiffon is agreed on, it is cultorian for the chiefs of the conquered, when they fit in coun. cil with heir fubduers, to wear fetticoats, as an aco lncwled gement that thes are in a fate of fubjection, and ought to be ranked among the romen. Their pas. tiality to the French has however talen too deep root for time itfelf to eradicate it.

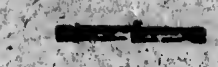

\section{CHAPTER $\mathrm{x}$.}

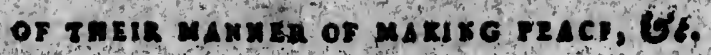

$\mathrm{T}$

HE wats that are carried on between the Indiati nations are in general hereditary, and continue froth age to age with a few interroptions. If a peace becomet recedery, the jrincipal care of both parties is to ayoid the ap fearance of making the firf advances

When they treat with on enemy, relative to a fufpenficn of holtities, the chief who is conmiffioned to un. derrake the negocistion, if it is not biou ht abcat bf the mediation of fo the neighboring band, abater pothing of his natural higughtines 8 eten when the affairs of hip

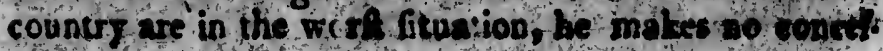

Eout

duis arm march,

is whic Not was at their in counte the for teried ctitito of the fó cau party were: their.

The and $b$ their. Ginitio 
onftant repre from them of the aggrande of their bat. clination, the that peoples. unity of Dhet.

ful eftimation re been driv. er every con. Meir conquer. lenother, and is cuftorian $y$ fit in couns is, as un ac. of fubjestion, n. Their pat. - depe roos

\section{, 66.}

the Indiati atinue from ace becomes is to aroid s.

to a fífpen. sned to on. he abcat by retenothing. iffairs of hip no tondis?
Sons, but endeavors to purfuade his adverfaries that it Stheir intereft to put an end to the war.

Accidents fometimes contribute to bring about 2 peace between nations that otherwife could not be pre. wiled on to liften to terms of accommodation. An in. Daree of this, which I heard of in almn\& every nation I pafted through, I fhall relate.

A bout eighty years ago, the Iroquois and Chipeways, 40 powerful nations, were, at was with the Ottagau. wies and Saukies, who were much inferior to their ad. verfaries both in numbers and firength One winter inar a thourand of the former made an excurfion from Whe Ontario, by way of Toronto, tewards the territo: ries of their enemies. They coaled lake Huron on its all and northern borders, till they arrived at the illand of St Jofeph, which is fituated in the ftrats of St. Mhe rit. There they croffed thefe ftraits uponthe ice, about iffeen miles below the falls, and continued their route Aill weftward. His the ground was covered with frow so prevent a dilcovery of their numbers thej marched in a fingle file, treading in each other's footfteps.

Four Chipeway Indians, pafling that way, obferved this army, and readily guefred from the direalion of their march, and the precautions they took, both the country to which they were haftening, and their defigus.

Notwittanding the nation to which they belonged ras at war with the Ottagaumies, and in alliance with their invaders, yet from 2 principle which cannot be ace. counted for, they took an initant refolution to apprif́ the formet of their danger. To this purpofe they hal tened away with their ufual colerity and taking a circult to aroid difcovery, arrived at the hunting grounds fithe Ottagaumies, before fo large a body, moving in to cautious a manner, could do. There the found $\mathrm{a}$ party of about four hundred warriors, fome of which Were Saukies, whom they informed of the approach of their enemies.

The chiefs immediately collected their whole force, and held a council on the fteps that werc to be taken for their defence. As they were encumbered with their Ginilies, it was impolible that they could retreat in 
There thire

atie the therefore deterwined to choof the moll ads vamageons fpot, and is gite the Iroguois the bell te ception in their power.

Not far fro the place where they then happened to. be, flood truo mall lake, between which ran a narrow neck of land about a mile in lengh, and only from twenty to forts yatds in breadth. Concluding that the Iroquois interded to pars flirough this defile, the unit. ad bands divided their litile party ste two bodies of: two hundred each One of thefe rook pot at the ex. tremity of the port that las nearef to their bunting grounds, which they immediately fortified with a brealt woth formed of palitades, whilit the uther body took a compars tound one of the lakes, with a deligh to hem. their edemies in then the had entered the defile.

Their fratagem fucceeded for ao fooner had the whole of the Iroquois entered the pals, than, being pro. vided with wood for the purpoles the $y$ formed a timilan breaf work on the other excremity, and thus enclofed their enemies

The Irogunis bon petceived their fituation, ard im. mediately held a conncit on the meafures that were ne. ceffary to be priffed to extricate themflves. Unluch-" 11 for them that had juft taken place, wich had fo far diffolved the ice as to reydes it inpalible, and yet there fill remained fufficient to prevent the a from either paling over the lake on rafts, of from twimming acrofs. In this dilemana it ras agreed that they thould endeave or to force one of the breat werls i but they foon found them too well defended to effect theit purpofe.

Notwithfending this difappointment, with the ufual compolure and unapprehentivenefs of Indians, thes anded themitres three of four days in fifhing. By this time the iee being quite diffolred they made them. felves rafts, wich they were enabled to do br fome trees that fortunately grew on the foot and attempted tw crofs one of the lakes.

They accurdingty fet off bafore dar break; but the Ottagaumies, who had been watchfu of thefr motions, perceiving thetr defign, detached on thindred and fifty anen from each of their parties, to oppole their landing.

Cherifide 0 pononts! thit poltes As foon Whesv fir We troguoi Miter findi Water, and however, $t$ bat bieity After th retreal, Sur of the field ton during pus fat at from the ro tifor vere: of lome of Bui had deftroged. Thich ever when dimi pay laad

The ria had been il sovila. II chot of th afcort of 6 terelted Cl altated b refufed the accept of

The bra the Othat of the Chi ánimolity d of the? gether the tore natio to bands. 
tholl ad - befl re

pened to. narror 1y. from that the the unit. bodies of: the ex. bunting I a brealt dy took 3 to hem file.

had the ing pro. 2 fimilan enclofed

and itn. were ne. Unluck. $\mathrm{h}$ had fo. and yet. in either gacrofs. esdeav. on found

he uffual ais they 38. By te them. of lome tempted.

but the motions, and fifty landing.

Thefe three hundred marched fo expeditioufy to the Wher fide of the lake, that the treached it before their pponents had galled, the flibre, ther being retarded by thit poles Aicking in the mud.

As foon as the confederates arrited, thes poured in When 1 fire, both from their bowe and mufquetry, on ite troquoie, whield greatly dilconcerted them s till the Witer finding their fiteation defprate, leaped into the water and fought theis way through the enemies. $T$ his. howeter the couldrot do vithout lofing mare than. wir their men.

Aft the Iroquois had landed they made good their. utsteat, but were obliged to leave cheir enemies mafters of the field, and in pofiefiton of all the furs the had tat. ken during their winter's hunt Thus dearly did they phy fot an unprovoled excurfiod 10 ficts a difance fom the route thes ought to have purfited, and to which. Whe were only inpllied by a fudden defite of cutting of 'ome of their ancient gaemies.

But had they known their Arength, they might have deftrojed every man of the part that oppofed thear: Thicb even at the firt onfet was onit inconfiderable, and then diminifed by the alion, totall, unable to make eny fead againt them.

The vietorious bitds rewarded the Chipeways, who thd been the means of their fuecefs, with a thare of ah boile. The prefled them to take any quantity thy chofe of the richelt of the furs, and cenc them under an dcort of fifty men, to their owh country. I be difins. letelted Chipeway, as uhe Indians in getieral an eldom attated by merventer motives, for a coiffiderable time refifed thefe prefents, bat weve at teng h parfagded th accept of them.

The brave and is ell concerted reiflance bero made 4 the Ottaganmies and Saulties, aided of tho mediatigh of the Chipevays who taring atide on this occhlion th ainitholity they hid so long borne thofe people, approf ad of the generous condue of thet four chief, werest gether the means of efeding ar reoncligtion betwer thele nations, and is procels of tim united them att? the bands of unit? 
And I believe that all the Indians inhabiting that ez tenfive country, which lies between Quebec, the banks of the Mififippi north of the Quifconfin, and the fettle. ments belongiog to the Hudron's Bay Company, are at prefont in a Aate of profound peace. When their reffef's difpofitions will not fuffer them to remain inactive, thefe northern Indians foldom commit holtilities on exch other, but make excurfions to the fouthward, againit the Cherokees, Choctahi, Chickafuws or lliinois.

Sometimes the Indians grom tired of war which. they have carried on a gaint fome neighboring nation. for many years without much luccefy, and in this cafe. they feel for mediators to beg in a neggociation." "I'hefé being obrained, the treaty is thus conducted:

$A$ number of their own chiefs, joined by thofe who have accepisd the friendly office, fet out together for, the country of thoir enemies ff fuch as are cholen for this furpofe, are chiefs of the molt exienfive abilities, and cf the greatelt integrity The bear beforo them the pipe of peace, which I need not inform $\mathrm{m}$ y reader is of the fame nature as 2 dag of trues atuong the Eu. ropeans, and is treated witli the greatef refpect and ven. eraturo, even by the mof barbarouis nations. I never heard of $m$ inftance wherein the bearers of this tacred badge of friendhip were erer treated difrefpedfully, or. its rights violated. The Indians believe that the Great Spirit never fuffers an infraction of this kind to. 80 unpanished.

The pipe of peace, which is urmed by the French the calumet, for what reafon il could never learn, is 2 . bout four feet long. The bowl of it is made of red inirble, and the fem of it of a light wood, curiouny painted with hieroglyphicks in varions colors, and a. dorned with feathers, of the molt beantiful birds s but Litis not in mi power to convey in idea of the various tints and pieating ornaments of this muich efleemed In. dian imjiperieas.

Erety mation has a diffrent method of decorating thefe pipes, and thoy can tell at freft fight to what band It belongs. It is ufed as an iatroduation to all treaties, and great cetremony attends theing of it on theff ocea.

The when il robateo care at. ground oughly. ing int bacco. Airs wat:

eiss, aft horizon ceircle wothe by the I the evil of the 1 ters. I agents, ward of be preff ino or: inftitor ground It i monthe the Sary and to giadati this bo. as if he any on Whe bion fo which" fongs this tin and, Selves ation. inesey clons: 
ing that ex

ing that ex

d the fettle. mpany, are When their imain inac. it hoftilities fouthward; or Illinois. war which: ring nation. in this cafe. on. Thefé 8

thofe who. sogether fors cholen for ive abilities, seforo them: m) reader ng the Eu. eet and ven. s. I newer. this tacred poafully, or ve that the lis kind to

the French learn, is 2 . ade of red b. curiouny Jore, and a. birds ; but the various Reemed In.

decorating what band all treaties, theff ocea.

\section{CARVER'S TRAVELS:}

The affifint, or aiddecamp of the great warrior, when the chiefs are affembled and feated, fills it with tobaceo mixed with the herb before mentioned, taking: care at the fame time that ro part of it toucties the ground. When it is filled, he takes a codl that is thor. oughly kindled, fr om a fire that is generally kept burning in the midt of the affembly, and places it on the to. bacco.

Atr foon as it is fuftitiently lighted, he throws off the. wall He then tupns the fiem of it towards the hear.cons, after this towards the carth, and now liolding is: horizontally, moves himfelf round till he has completed reircle; by the firf action he is fuppoled ao prefent it: to tho Great Spirit, whofe ald is thereby fupplieated; b) the fecond, toravert any malicious interpofition of: the evil spirtts, atd by the third to gain the protection of the topitits tihabiting the ait, the earth and the wat tors. Having thus fecured the faror of thofe invilible: agents, in whofe puter they fuppore it is dither to for Fard or obftruet the iflue of their prefent deliberationt. be prefents it to the heteditary chief, who having taken." tivo or three whiffs, biows the froke from his mouthy. itft towards herven, and then asound lim upon the: ground.

It is afterwards put in the fame mannes into the mouths of the ambaffadors or Alangers, who obferve the fame ceremony, then to the chief of the warriots and to all the othet chiefs in turn, according to their. guadation. Juring this tims the perfon who ezectites this honorable office holds the pipe llightly in his hand, as if be feared to prefs the ficred inttruivent 3 yor does. any one prefume to touch it but with his lips.

Whea the chiefs who are inftructed with the commif: bion for making peace, app: oach the town or camp to. which they are going, they begin to fing and dance the fongs and dances appropriated to this occafion. By: this time the adverfe party are apprifed of their arrival, und, atesthe fight of tho pipe of peace divelting them. Selves of thair wonend enmity, invite them to the habits.

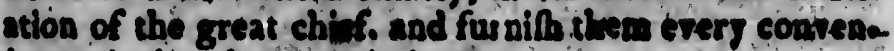
inec during the negociation. 
A courcil is then held and when the fpeeches and debres areended, if no obltrutions arife to pit a Alop to the treats the painced hatcher is boried in the ground, as a mesph al that all animolities between the contend. ing nations have cáfed, and a peace tafen ploce. $A$. mong the ruder bands, fuch as liare no communication with the Europeans, a wat club, painted red is buried, inflead of the biltched.

A belt of wampum, is alfo gizen on this occafion, which ferves as a ratificatio of the peace, and records to che latef pofterity, by the bieroglyphics into which the beads are formed, evers Aipulated artible in the treats.

Thef belts are made of linalle found on the cuats of New England and Virginia, which are fored out into beads of an oblong form boone a quarter of an inch long and nonnd Ifle otbe bead Being frung on: leather hrings, and feverd of them fened neatly logeth. cr. With fine finewy threads, they then compore what is creced a belt of rampam.

The Anells are generally of two colors fope white: and other violet but the later are more highls elleem. ed than the formur 1 bey ure held in as much eftima. tion by the Indians, as gold, Glver, or precious Rones; are by the Europeans

The belts are compaced of ton thetres or a greater: number of Arigg, aceording to the importance of the affir in agitation, or the dignity of the perion to whom it is prefented On more trifing ncchliuns frings of there beada are prefented br the chief to each other, and frequently worn ty them about their ne cks, as iluable ormatient. 
ceches and pixt a ftop. he ground, he contend. plise. A. munication is buried,

is occafion: ind records into which ide in the

i) cuafts of ed out into of an inch Gring on dily togethoff. what is

fome white: this elleem. uch eftima. ious Pones;

ra greater: ance of the: in to whom Arings of: each otlier, ie cke, as
A

S I have before obferved, the indians are greaty addieled to gaming. and will even thake, and lofe with compolure, all the valuables they are poffeffed of. They" amule the infelves at fevetal forts of games, but the prin. cipal and moft efteemed among the in is that of the ball, thich is not unlike the Europern gape of tennit.

The balls ther ufd we rather larget than thofe made. uf of at tenuis, ard are formed of a piece of deer 1 in's Which being thoiltened to reader it fupple, is ftuffed hand with the hair of the fame creature, and leweds with its finews. The balf Atick, are about three feet longs, at the end of which there is fired a kind of racket. refembling the palm of the bajds and factioned of.

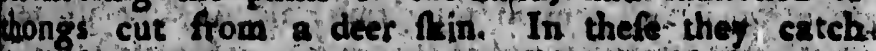
ate ball, and throw it to a great disanoe, if they are. ot prevented by foute of the oppofise part's, who fis'. wintercept it.

This game is geaerally plajed by large companies i hat fometimes confif of more than three hupdred 3 and is not uncesnitoa for differeit binds to phy againft. ach other.

They begin by fixing two poles in the ground at a-. out fix hundred yards apart, and on of thefe goals. Jons to each party of the cotribatants. IT ball is. Hown up high in the contre of the ground, and in $\mathrm{s}$. ireat line betwen the goils : towards which each par. ondeavory to Arike it, and whichfoever fide firls infes. it to reach their own goal, reckons towards the: ame.

They are fo exceeding dexterous in this manly exerfie, that the ball is ufually kepi lying in different df: Ations by the force of the rackets, without souching is ground during the whole contention if for they are. br allowed is catch it in their hands. They, run with mazing velocity in purfuit of each other, apd when 
Qne is on the point of hurling it to a great diftance,an an. agonift orertakes him und by a fudden froke dafties down the lly.

Ther plas with fo much-rehomenoe that ther fre. quent wound chet ot ler, and fome times $a$ bone is broken $s$ but notwithltanding thofe afcidents thew neve et eppears to be ans foite os ranton ezertions to éfeq them 1 hor do an diputes cker happon betwoen the Earties.

There is onother efme als in ufe among them worthy of ta nogt, and this it tha game of the bovl or platter: This game is phjed tiegmeen to perfons only. Each

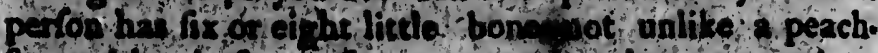

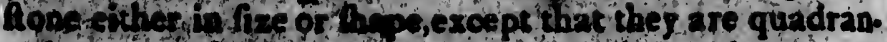
gular th to of the bees of which at colsred black, and the others whice 1 hele bey throw up into the air from Whence the fill ingo abovlior plattre ploced underneath, and made 00 fin rowads.

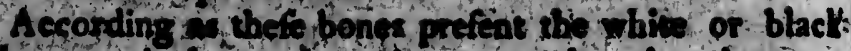

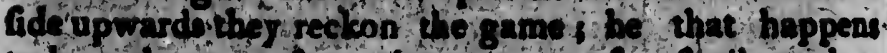

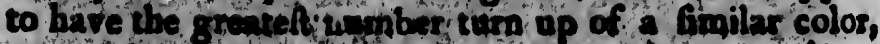
count five poins i md forts of on

The wimning party keeps this pleces and the lofk Jielda his to strotber who is appointed by ons of the um.

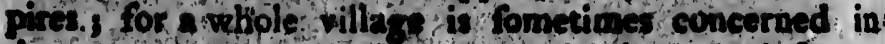
the party, and at timo one bund plogs ogint an other.

During this plos the Indians appear to bo greatly agitared, at every decifue throw they fte up a hideous Prout They mak a thoufind comertions, addrefling themelres at the frime time to the bopos and Ionding with imprecetions, dhe evil fpiries that afft their fuccefo ol entagonille

At this gane lome will lole cheir apparrel, all the noveables of theis cabins and fonctimes even their lib ext) 3 ngswithltanding there are no people in the nni.

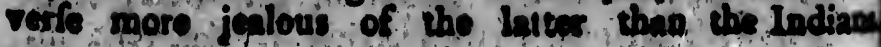
ate 
:,an.an

dafties

ief fre. bone is ner. - effer een the

iworthy platter. Each peach: juadrin. ck, and inf from èrneath,

xt black" fopporis. ar colos,

che lofer the unm. arned in iint 20.

greatly hideous didefing londing itucceffo-

1, all the thieir lib. the uni. lodian
CHAPYIR XII.

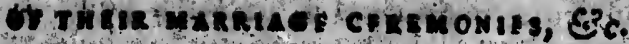

1

HE Indiand allow of polygamy and perfons of

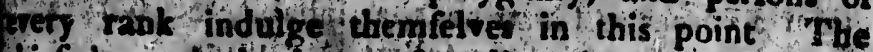
Chiefs in particullitr have a leraglio, which confins of 20 uncertedin number, ufrally from fir to twelve or fourtecen. The lower, raats are pertititeded to take as many as there a probability of their being able, with the children

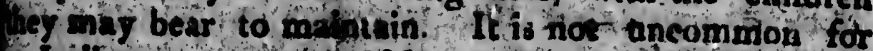
Indiun to marry tivo Afters, fometines if there hap. in to be more the whole number send not ti ithltand.

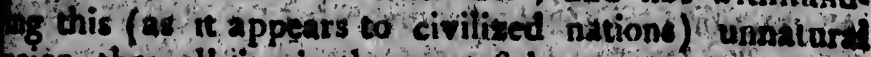
gion, they all ive is the areatelt harmony.

The younger wives ane fabminfirve ia the elder, and Whot who bave no ctilldrin, do fuch meaial offices for Itoofe who are fertile, if caufes their fituzion to difiet but lietle from a Qate of fer vitude. However ther perform every injunction with the greater cheerfulners, Ihppet of gaining thereby the affestion of their huts ands, that they in their torns mas bave the happuners Shesowning minthery, and be entilled to the refpet as. indent on that Alate.

It is not uncomimon for an Indiao, allihough he taket po timfelf fo miany wives, to live in a date of consinenes the many of them for feveral years. Such as are ndi Sormuate as to gain the favor of their huilband, by

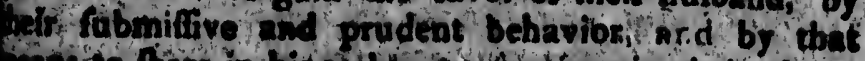
sans to thare in his embtrices tontinte in their virgin te doring the whole of their lites, exceppt they happen be prefeated by thin to loope Aranger chite, whole hode unong them will nof edmit of his entering inted more talling conneation In this cafo they mbmit w

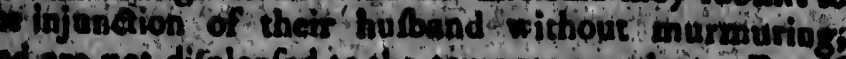
at are not dilpleafod io the temporary uniox But?

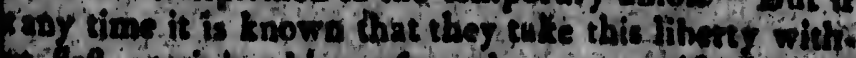

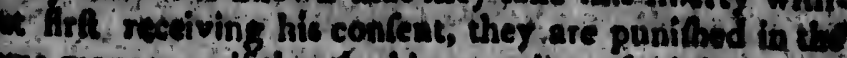

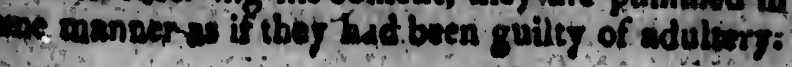


This culfom is more prevalent among the patione, which lie in the ingerior parts, than among thofe that are nearer the fettlementa, as the manners of the latter asc rendered more conforthable in fome points to thofe of the Europeans, by the intercourfe they bold with them.

The Indian nations differ but little from each other in their murrigge coremonies, and lefs in the manner of their divorces. The tribes that inhabit the borders of Canads make ufe of the following callowin.

When a young Indian has fixed his inclinations on one of the other fex, he endegvors to gain her confent, and If he fueconds it is never known that her parents ever obftrua their nnior. When erey preliminary is azreed po, and the du s appointed, the friends and acquaintance of both parties afem ble at the boufe or tent of the olt a nolnton of the bridegroean, where a fealt is prepar od on the oceafion.

The compons who meet to affit at the teftival ate Jomgtimes very thitherous : they cance, they fing, and enfer ipio evert other diverfion ufoally made ufe of on not of their public rejaicings.

When thefe are finilied, all thofe who attende merels out of ceremony depart, and the bridegrocn and brids ore left alone with thice or four of the neas Q ind oldef refarions of either fide; thofe of the bridegroom being mens und thoie of the bride, womea.

Prelently the bride attended by thefe fow friends hering withdiawn herfelf for the purpore, apperits a bo ot the doors of the hotrs, and is led in the bride boon wlio lando read to receive her. Having no Ghen their tation, ot a tact placed in the centre of the trow, they hy hold of the extremities of a wand, abou four feat low 3 by which they continue feparated; whil the old act proaounce fome thort harrangtes fuitabl to the cecalion.

The married couple after this make a public decle Fatow of the love and regard they entertain' for ead Whet, and thill bolding the rod between them, dang and fing. When they have finilhed this part of th

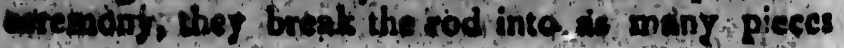

Pris. ail The bi hich of iend he abliged aring s. shil athe to anies the Whed - fare eir frieo matime Citnefles: Ge day re out to le od Which ito the fil This hats 5 eparation ill betwe (W) mont When a ave been ireen thes y the Ińc oman is: (Though cquents tho bave. ubiatho jetics: of gerving cept in $t$ deved as Althous ety litule ies, Ihyre ve a fing hich feed 


\section{CARVER'S TRAVELS.}

16 pation, ofe that are - latter are to thole of with them. each other manner of borders of

ions on one infene, and arents ever $y$ is azreed quaintance of the olde $A$ is prepars

leftival are fiug, and le ufe of on

10 attended bridegrocm if the nean iofe of the de, women. evi friends apperts al $n$ the bride Javing nor entro of the rand, aboul rated, whilf ties fritabl

ublic decla in' for each bem, danc part of it

7 pieces

4an jieces as there are witncfles prefent, who each

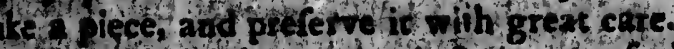

The bride is then telonducted ont of the dhat at hich fo hited, wherd her young companions wait to tead her to ther fatter houfe, there the briucgroom obliged to feek her, and the marriage is conflumated. Wr of th the wife tumaine ar hit father's hothe till the 4s a hild, what the packs up bet appartet, which is 11 the fortunt the is genterally poffelfed of, and accom. anie her hulband to his habiation.

When from an dinike d teparation takes piace, for The 2 re celdain known to quatrel they generally give Beir friends a few days notice of their intentions, and matimes offer tenche to jurtify their conduct. The itneffes who wete profent at the marriage, meet on The day requelted, at the thoufe of the couple that are a. out to feparate, and brifging with thent the pieces of od Wich tliey thad received at their puptids throw them to the fire, th the prefence of alt the parties.

This the whole os the ceremony required, and he ieparation is carried on withont any murmurings or ill iill between the couple or their telations, and aftet a bw months they are at liberty to marry again.

When a marriage is thus diffolved, the childred which Wave been froduced trom it, are equilly divided be Ween the a : and a children vie thee med a treafute $\rightarrow$ the Indians if tie number hapens to be odd; the oman is allowed to take the betrer half.

Though this culon feem to encourge ficklenes and rquent feparations, yet there ate man of the Indian's tho tha ve bat one wife, and eriog with lis a fate of $c 0$ th hubial happinels not to be excseded io more refined to. Seties There ase yto nos a fet infances of wom $n$ referting an inviotable acuachment to theit hio bands, facept in the cates befot dientioned, which are not cons

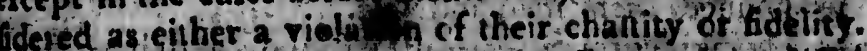
Although I have fid that the Indianithations diffet

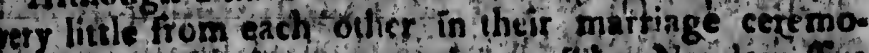

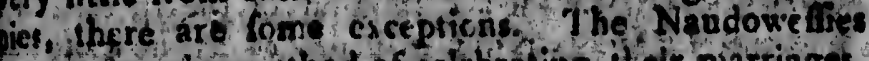
we a ling ular method of celebrating it elr narriage. Which feems to beár ino refériblátice do those mede ura. which feems to bear 
of by any ocher pation t pafied through. When one theix young men has ated on a youts woman he?

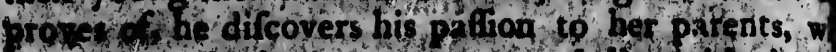
Cined an invitzion to come and live with them thirititent.

1. Heccordingly accepts the offer, and by la doing zater to sefde in if for a whole rear, in the charae of a menial fertapt During this the tie hubts, a brings all the game he lills of the fonily by whi deeine the father has an opportinity of teing whet tie 6 able to provide for the lupport of his daugh ond the childres that might be the confequence of th union. This however is only done whilf they are you men, and for their fire vife, and not repeated like? tob's forvitudes.

When this period is expired, the marriage is folen ired After the cuftom of the country in the followi manner. 1 hree or four of the oldet male elations The bridegroom, and as many of the bride's aceom Wh the young couple from their refpedive tents, to open part in the cenure of the camp.

The chiefs and warriors, being here aftembled to ceive them, party of the latter are dravn' up in ts Fank on edch fide of the bride and bridegroom imm diatel on their arrival. Their ptincipal chief then quaints the whole allembly tith the defign of th meeting, and tells them that the cuuple before the mantioning at the fine tinte, their names, we come WYow publicly their intentions of living to gether as $m$ And wife. He then als the two young people alt nately, whether they defire that the union might til place Aaring declared with an audible yoice that th do to the varriors fix their arrove, and difcharge the over the heids of the married pair 8 this cone, the chi pronounges them man and 2 .

The bridg goom then turu round, and bending bodf take his wife on bis back, in whith manner cartes her amidf the acciamations of the tpectators his teit The ceretiony if fucceeded by the molt ple tisl fear the nete married man can afford and for

lonces, feltival:

Divoress that? pomplifhe

Adulen

airhed wi

ir bites o

enfíis.

tent on:

echidre

to the $y$

Ther are

Among

et are in

X notwit

a writers

Tome the

or that

raratify

Howed of

Heil.

When or Dethax? efs that bit fuit 1

It hies $\mathrm{t}$ nowleage furdinat Wh or has a tate o ature. I heck or 5 The can I them:

As the: ters, of te ents or bi bo $\mathrm{s}$.

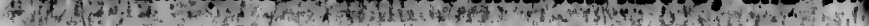




\section{CARVERS YRAVELS.}

207

When onte oman he pitents, w wils them

Y ladoing the thatá * hubts, 3 by whi eing whei bis daugh pence of th ey are you eated like

ige is folem the followit e relations e's, aceomp tents, to

mbled to vn'up in t? groom imm chief then ? fign of th? before the tre come gether as $\mathrm{m}$ people alto might th Dice that th Scharge the one, the chit

bending h inarnicer fectators he noft ple is and fon
Ithnces, according to the ufual cuftom, conclede telival.

Divotces happen fo feldom among the Naudorvefies, It had the an opportunity of learning bow they are complified.

Adul in is efterned by them a heinous crime, and withed with the greateft riget. The hutband in the Mibites of the womants nofe, and depatration inftan: enfies. I daw an inf ance wherein this niode of puinThent was infiated, whilk Itemained among bhem. A children, wheh thls happens, are diftribused accond. To the ufial culton obctived by obler nation, that: they are equally divided.

Amons the Indiahs as well as European nations. 2e ere mans that devote thempelves io pleafure, \& potwithltaling the accounts given by fome wiods in writers of the tifigidity of an Indien conalcutions. tome the zealous votarits of Venus - The young whr. ors tiat are thus difpofes. feldom want opportinitifes

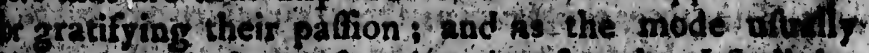
Whowed on thefeoctifions is rather fingular, I thall ab the it:

When one of thete young debauches imagaines from. b betarior of the perfon te his cholen for hig wir. iff that he diall not moet with and great obftrueliots bit fiit froth her, he purfues the following plati.

If hite been alreaty oblerved, that the Indiatieac. nowledse no fuperionty, nor have thej, any tdeng of: Thotdination, except in the heceffarv regulations of thet Y of hunting pathet 3 thes confequently live neatly a late of equality purfiant to the firt princiules of gture. The loter the refore is not a pprehentive of any theck or coptrol in the accoroplifintent of his purpofes, The can find a convenient opportenity for completing. them.

At the Indians are alfo nnder no apptichenfion ofirobSers, of fectet enemion, thes leave the doors of this ents or huts unfaltened during the night, as vell at in tho tr. Two or three bours after fund fet, the daves Th people coter the fire, wat is getheratly burning. 


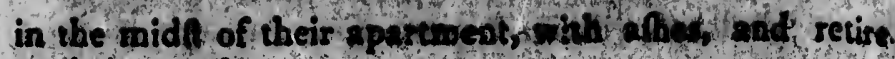
to thetr repore.

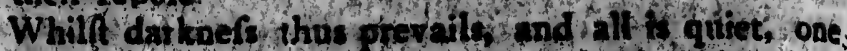
of thefe fons of pleafure, wrapped úp clocely th his blan. ket to prevant his being known, will tometion enter

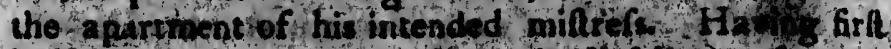
Jighted at the fmothered Ifre fmall fplinter of yood. which anfwers the jumpof of andeb, to opprosches the pluce where the repofes, and genthy pullins away. the covering fom her head, jog her till fhe avd kes. If Pesthen tifes op and blows ont the fogt, he needs no further confirmation that his comptat is not dragreed

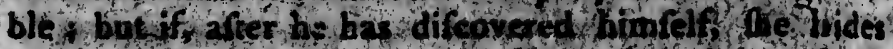

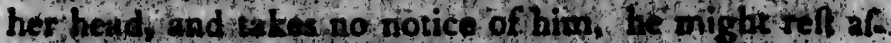

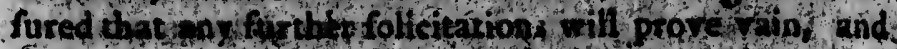
chat it is nece targ immediately for bim to retite.

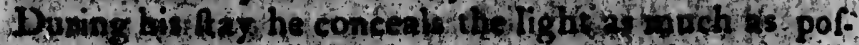

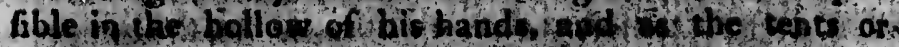

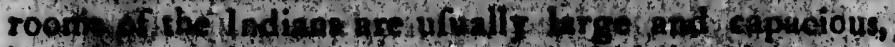

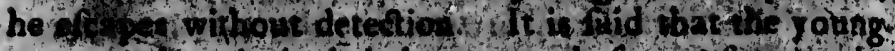

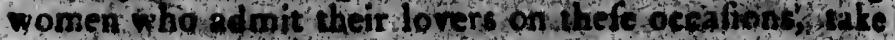

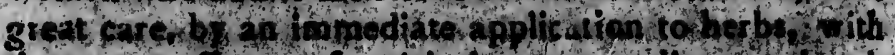

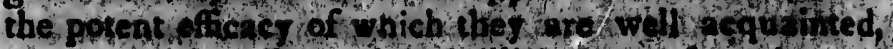
to prevent the efeess of thef Mict inor from bacom. ing viffis o, for fould the hachy l gonfequenect offue.

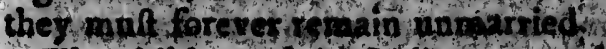

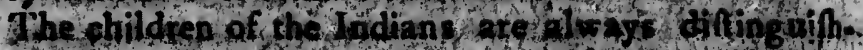
ed hr hl name of the mothe s ond if a vopon mar.

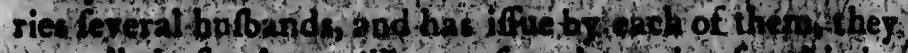

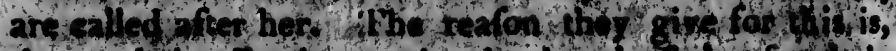

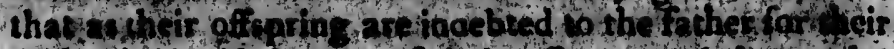

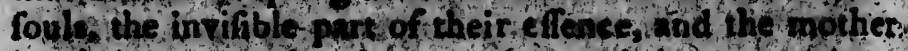
for their corporeal and apparent part it ir mort tefon. al that they thould be difinguifhed by the name of the latter, from whom they indubitably derive thet bing. than by that of the father, to which a dnubt might 10 mes. times arife whether thes are jufl ontided.

There are fome ceremonit mate ufe of by the th. dians at the impofition of ho napes and it if confly. by them as a matter of gteat Importance 8 but aut thefe are I could never learn, through the fecrefy of. 
ared on the occafion. I only know that it is ufually,

ad recire.

itiet, one;

his blan:

not enter W 6 irl of rood. proaches ing away: alies. If oeed no. arfagreen Trethides: bivelinat. Find and ite. . . .

146 pol: tehts or Qpréous, Woung. ond hituke beroith gut sined, ip becom.

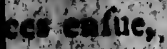
$\mathrm{H}+\mathrm{C}$ ing silhnot t már. 4 whey DAlisis, torl enir 6 mother 4 ofelon. te of the. it bins: betones the the nfis ue taut sefy of

inen wheb the chilturen have paffed the age of in. incy.

Nothing can erolad the tendernes thown by them to: heit offspring, and a perfon cannot reoommend himIf to their tarom by any method more certain than by

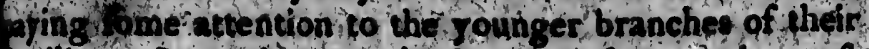

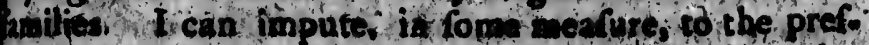
ats I made to the childron of the chiefo of the Kaudo. iffes, the hofpitable reception 1 edt thith when among (it):

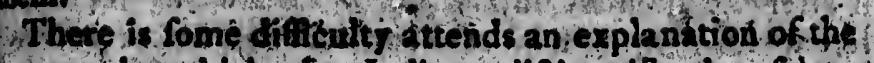
- nner in which the Indians dintinguilh themflves monch other. Befides the nathe of the anienal by Whaterery nation and tribe is denominated, thowe are, thers dhat are perfonal, and which the children neceire? hom their mothery.

The chitef are alco dillinguifhed by a name that has? ther fome reference to their abilities, of to the hieroWphic of thein fomilies 1 and thels are acquired fiter the arrive at theage of manhood such a hitolis. Whed themitve other in their was or hunting pars

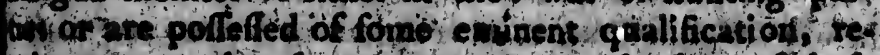

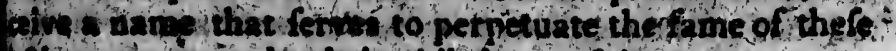

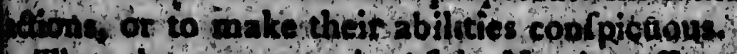

Thus the great tarrior of the Nau do reffies wan name

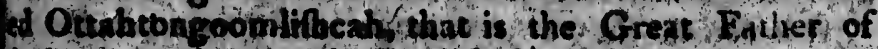

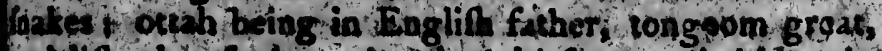

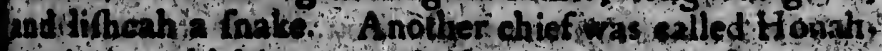

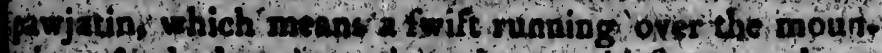
Whe And when theriad optod the a chief smong them,

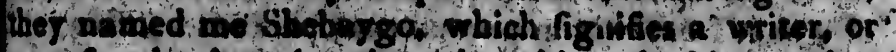

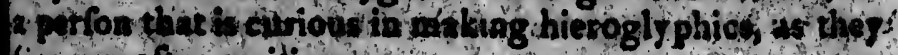
tiv no often witiog a

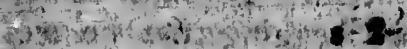




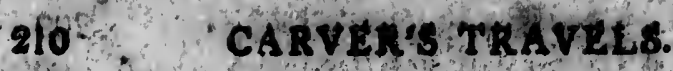

- vilong

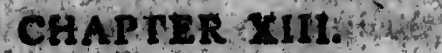

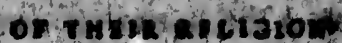

ti:

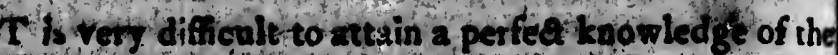

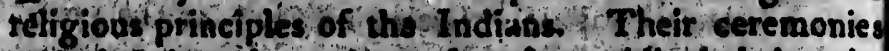
and doatines have betr lo often ridictled by the

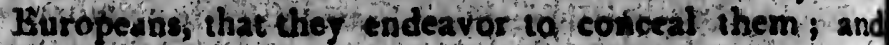
if after the greatel inthacj 70 defire aby of them tóterplain to you theit ff lem of jolgiont 20 prevent yourtidicale, the intermix tith it many of the tenets they have tecetred of the French unitronirics fo that it

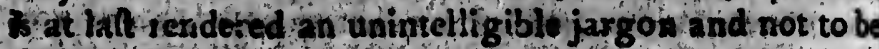
defietded upon:

Such as I could difcover among the Maciowefie

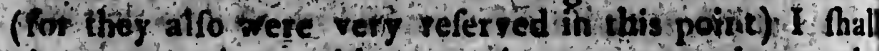
give thy teaders onithout paring any titention to the acce tis of others. $\mathrm{s}$ s the religion of that peopl

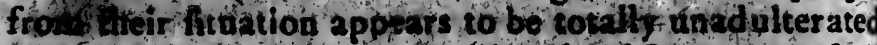

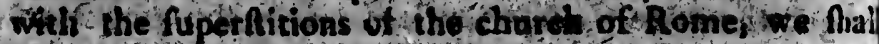

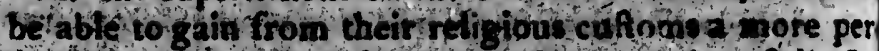
fodudea of the originat tenets and cercmonies of the In dians in goneth's that from thor

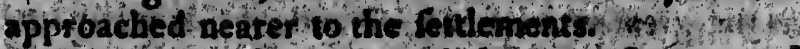

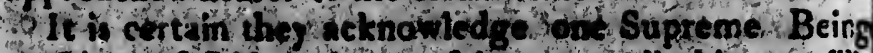
ot Giver of life, who prefids ofem all things. it $1 \mathrm{~h}$

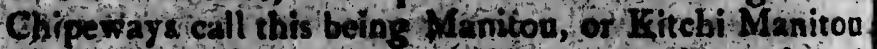

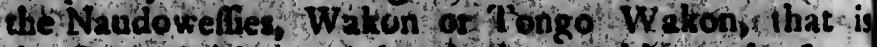

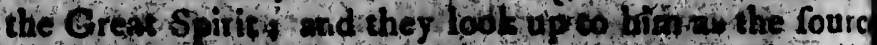

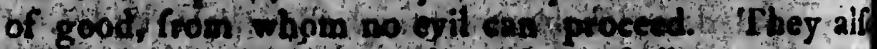

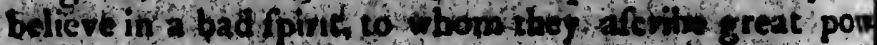
et, and foppof that though his sm th the evi which befall mankind are infliced 1 o him therefor do they proy in theit difrefles begring that he wouk either avert their tronbles, or moderate then when the ite no longer avoidable.

They fay that the Grent Sptrit, who is infaitcly good neither withes of is able to do aby mitchief ro mankind But on die contrary, that he lhowers down on them a

the ble timully binman. the wil They derteg: the mprals traondin rivers 0 and lis os: flong: fingular? orations Supator greatibo fidet the Winneb. Si Anoh

But ac nexto th ceptipns applar to of their though 0 of the curlty fuctire $f$ ? ther o without this perio Thas lightuls unclowde the foreft filh, thic tiil, or 3 live forev Ecrtion 800

To inte 
the blefings they deferve w whereas the ovil fpirit is contimally empluyed in consriving how he may puisifl the buman.race $t$ and 10 do y hich be is not only poffeffed of the vill but the poirer.

Ther hold alfo that there are good lpirits of a lefer. docter who have theit particular dopartherts, in which. thet tre conltant/ coneributingth the happinefs of,

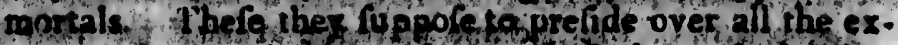
trapdinary padudions of nature, Iugh as tho le lakes river of movgtain that tre of ungomm on maghitudel. and like wis the bea s, birds. Ghes, and oren regitables, on ffores that areeed the rell of their fecces in fize or. (ingularity. Io 211 of thef they pay lome kind of ad. orztione Thus when then artiv on we borders of $B$ te Superiar of the badk of the Miffippi or any of her. great body of water, the prefent to the Sprit who ree lider thete fome kind of offering, as the prince of the: Winnebagoes did theo he attended me 10 the falls of Si, Anthons.

But ac the fame time $\mathrm{f}$ fancy that the idea the $29 \%$ nex to the wrord firit are very different from $=$ conceptipas more ealightened nations eptertin of th thes. apport to falhion to themelves corporeal reprefentations of their god, and beliere them to be of a huma form $f_{\text {s }}$ though of 4 mazure moge cretlen than man.

of the fam lind are their fentiments reletrve to fum curity They doubt not but the thall ext in tome futhe fore the bowever tancy that their employ ments there, will bertmilar to thole they dre engaged in liere, withous the tabor and dificulties annered to them in this period of their exiftence.

The conrequently expect to be trantlased to a de lightu counts. Where thes fhall always have a clear. unclonded $k y$, and enjoy 2 perpetual Spring i where the furefs will abound with gams, and the lakes, with filh which migh be taken withont 2 painful e zertion of Aili, or 91260 ions pirfinit in fort, that thes fiall live foreve in region of plenty and uajoy every gratiGiction they delight in hers in a greater do $80 \mathrm{cos}$

To intellequal pleafures thes are Arangers a hor are

aitely good

mankind

os them a 
the fe included in their cheme of happinefs. But

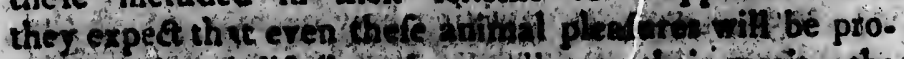
portioned asd diftribated accorting to their metit; the filfial hunter, the bold and finecefful $\rightarrow$ arvior, will be eatitied to $\alpha$ greater late thent thof who through indolence or whit dffill cennot boaft of aby fuperigrity over the combon hard.

The phthots of tho theiwns who we at the fame, time their phrficians an thiter conjurter of hall thes heal

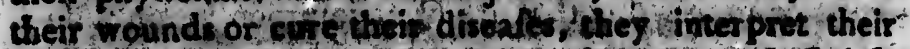
drems, give them the prosedive charms, and fatisfy that defire thoth is to prevalent atnong them of fearche ing into futurity.

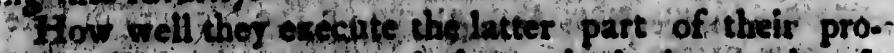
ferinal angagements and the methods ther wale ufe of on fome of thefe ocestiona, I hate already hiewn id the arertions of the prief of Killifinoes, who thes for: tuinate engugh to laceed in his extrzordinar y attempt near Lake Superior. They frequeatly are fuctersful, Mkewif to adminifering the falubrions herbs they hate adquired a knowledge of but that the ceremonies they male ure of during the adminiftration of thea contrib:

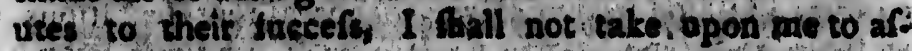
ifit:

When anf of the people are ill, the perlon who is invelded whth this tripple charader of doctor prieft and magician, fite by whe patient day and night rattling in his cart a goad nell fillad with dry beans, called $\mathrm{q}$ Chi. chicote and malting a difa jreable nolfte that cay fot be tiell defcribed.

This uncouth tharmony one would troagine fhould diliwis the fick perfon and prevent the good etifers of: the doctasts prescription f but on the contrary they be. lieve that the method made ufe of contributes to his re. covery, by diverting from his maligeant purpofes the $e$. vil fpirit who has infliged the diforder $;$ or at leaft that it will take of bis attention, fo that ho flall not increafo. the malady. This ther are credulous enough to ims:gine be is conftantly on the trateb to do, and would var. is bis invereracy to a fatallenges if phey did not thws charra him. 
(5.) But:

Wbé proerit; the will' be through eperiogity

ane, time they heal prot their ad Iatisfy. of fearch:-

their pro-Thalse ufe" ady Mewn hotwas for: 7 attempt fuceefsful; ing hate vonics thes an contrib: ben trie to af:

Por who is prief and rattling in llet:e Chis car lot be

ine hould ativers of I) they be. es to his re. poles the e." at leatit that not increafs" ols to ima: Trould tear. Gid not thes
C.ARVIR'STRAVELS.

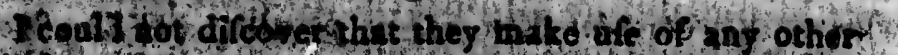

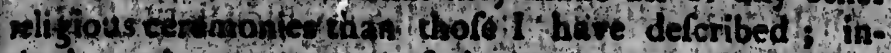
dead, on the appetinget of tho nes moes they dance.

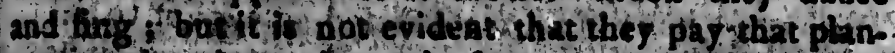

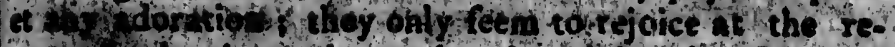
curn of luminary that mikes the night chewful, and? whith flofolontight then or their wrat when thes. trath in the abferes of abe fon.

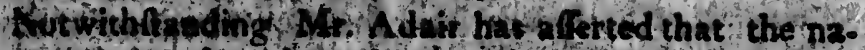

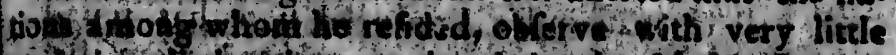

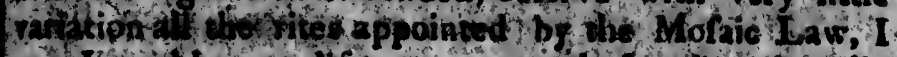

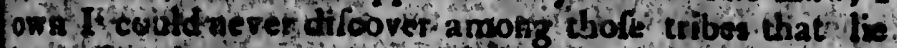

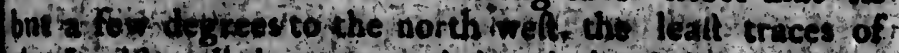

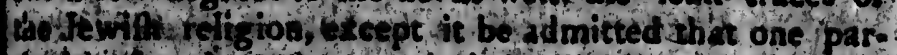

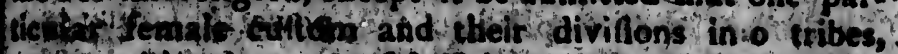

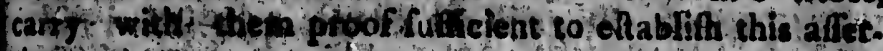

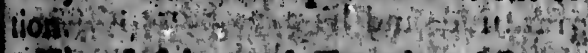

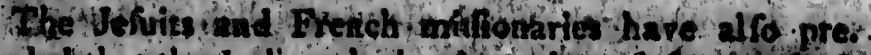
maded the the Indians had, whost they firft the ted:

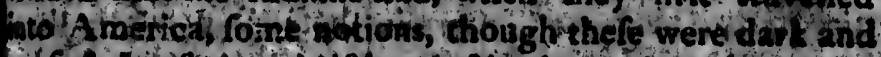

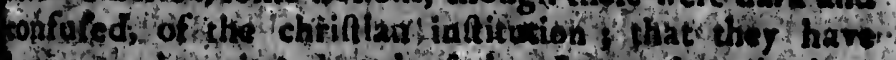
wh gleady agivated ac the cight of a crots, and given rof by the impreflent malt ph them; that the o vere

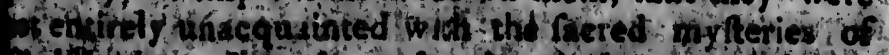

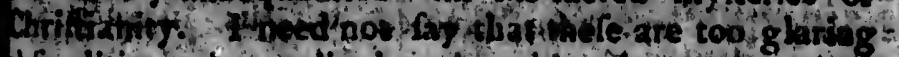
blurdities to be crediced and could only rective thiv iffence from the zeal of thofe fathers, who endeavon. dat once to give the public a hetter opinion of the iscefs of their miffions andstoradd lapport to the cauro hex wein engaged in.

The Indians a ppear to be ii thisin roligious principles, ade and uninftrusted. The doetrines they hold are Fiv and fimple, snd fuch as have boéigenerally impref. 4. on the human mind, by tome means or other, in the offignorantages They however have noo deviated?

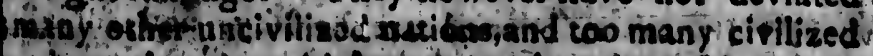

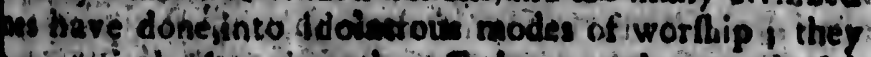

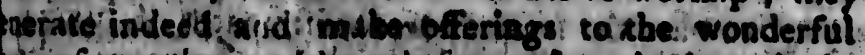
its of ureation, as 1 hate before obfotvedes bue whech. thos rifes und performed ot account of the impiefition

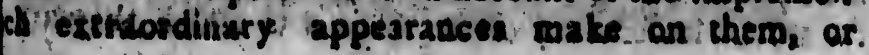




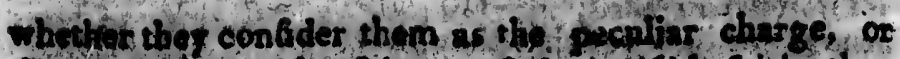
the ufual places of rofidence of the invifble frits they 2ckinowledge, I cannot poffitively deteraping.

Tho hnowa mind in is unculivand the is apt to at tribe th extro or dinany occurrences of prure fuch as earth quates thunder and hurricenes to the incetoffo. tion o unfen beings, the wroubles und, difefers afo that. are annexed to a favage fifo the apprahogafions antendant

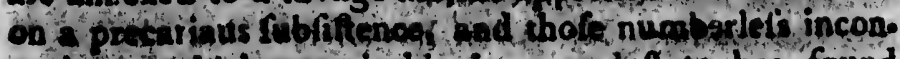
venubes shich man in his improved fort has found metas to rethed, are fuppofed to proced thot the interpofition of evil Cpirity the favage confequentls lives in enatinual apprehenfions of their unkind attacks. and to avers them bas necourio to sherme to the fan. tafic ceremenies ot his prioft or the gomerful isfenence of his Minitdos Dear has of courf a groater tharec in this devbtions than gratitude, and he pays more, atter-

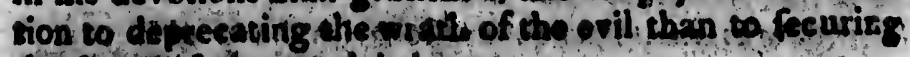
the fort of the good beings

The tralian, hoincres, entertain the ablurdites in coibuon thith thos of exert part of the glabe who. have not yet been illuminated by thet religion shich. onlf can difperf tho cloude of fuperfition and igno. ranes, and aber we as free from error ar a peuple can

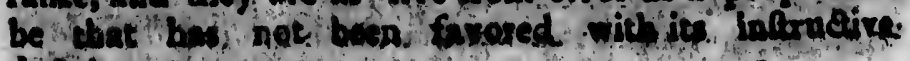
docinipes it

\section{CHAPTER XIL}

- Than Discasobo E?

T.

H. Indiuas in genered are healthr and fubjeer but to fer difoafet, many of thofe that aflitie civilized natinat, and we the iniciediate donfequenges of laxury or llath, beiag not biowa among chem, however, the bardfhips und fatiguee which thay endure in hunting or wari the iaclemency of the feafons to which thes ase 
stger or mits they

pt to al luch as nte $=0$ ofi. atc that arendant ti incon: as found then the afouentls dittacks: a the fan. in inence: art Diare nore, attepcot fecuricis.

ditive in Llabe who: Which. and igno. peuple can infornatirs:

find subject ie civilized of of lazury owever, the in thunting liob thon are

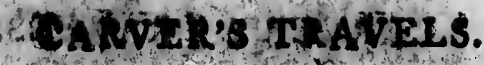

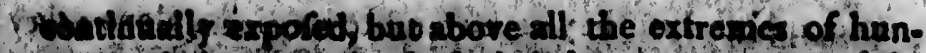

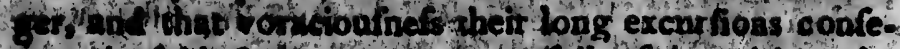

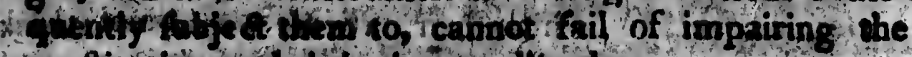
conftitutionsted bringing on diforders.

Dalns and weakneties in the fondach and brealt are 94 thimes the refilt of their long falting and confump.

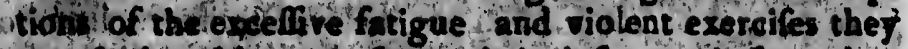
expofithonferes to frow thoir infanon before they Have fufficient Anength to Luppont them. But the dif. - bother to shioh they are mof fubject is the ipleurify: for the removal of which, they apply thein grend teme. Ay and prefervation againft the geberality of their com. Shaint, fweating.

WT The wanher in which they conftrua their flones for this purpofe is as follows i they fix feveral fmall poles th the ground, the tops of which they trift ugethet fo Sto form o rotunda this frame they cover withinins 9 or blankers, and they lay thein on with for mueh nize. it, that the air is kept from enteriog thro $1 \mathrm{gh}$ any $6 \mathrm{~s}$.

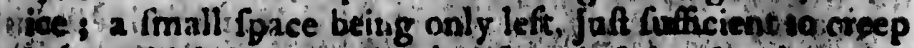
Wh at, which is immediately after clofed. In the mid. de of the confined building they place red hot fones, on which they pour water till a Ateam ariles that prot duces a great degree of hicat

IThis caufes on inftentaneons perffination which thety therewf as the pleafe.' Having continued in it for fome time, they immediately baften to the nearefl freani ahd plunge into the water; and affer bathitig therein for about half a minute, they pue on their clothes fie down and fimoak! with great compofure, thoroitghl's purfuaded that the remedy nill prote efficacious they often make' ufe of this fudoriferous method to refrefi themfelves, or to prepare their soinds for the managed

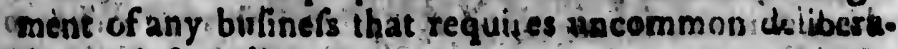
rion and fagacity.

* They are likewife afflided with the dropfy and para. Ittic complaints, which, bowever, ure bit vor y, feldom known among them.

As a remedy for thefe as well as for fevers the ofe of lotions and decotions, compoled of herbs, which the plyfficians know perfectly woll how to recupound 


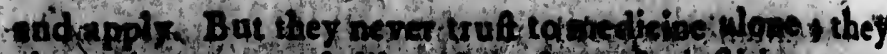

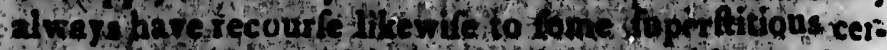

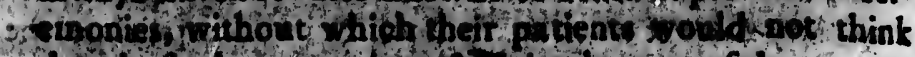

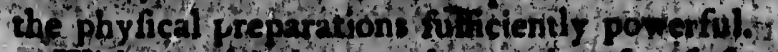

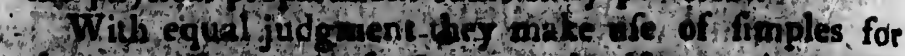

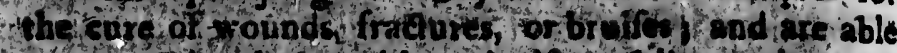
to extre d by thefe, without incifing, Plintets tron, or

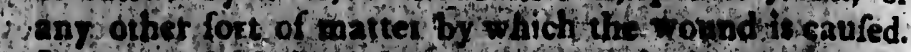

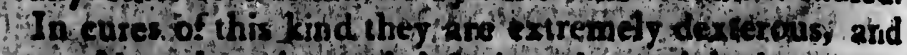
eomphtec them in much lefs time than night be expect. ed from their mond of proceeding

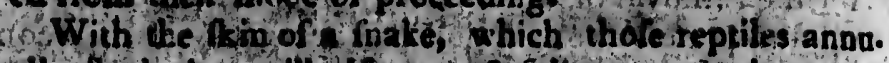
Dlly thed, the will alro extrae fplinters it is amaz: to fee the fidden efficac of ithis application, notwith. thanding there does not appear to be the leaft moilture remaining in it:

Wt hes long been a ribjea of dippute, on what contiment the veneral diterfe hift received its defruetive

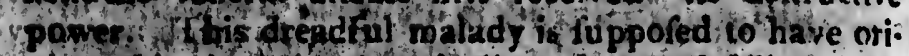

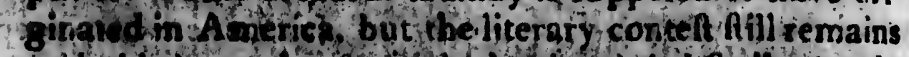
inderided st to give fone elucidation to in I hall re mark, af that in $L$ could not diconer the leart traces aming the A tanibowellies, with whom I refided fo long' and was alfo Informed that it was ret vilko wh a mong the thore wett.

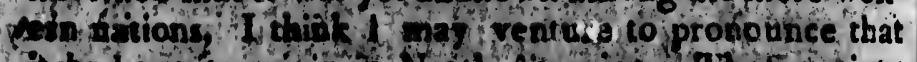
tat had not its origin th Noith Americe. Thofe nations - that have any combritication nith the Europeans, or Who fouthern tribet, are greats, willeted with it, but litbey have oll of them acquived a knowledge of fucti

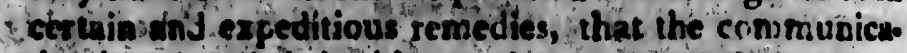
sion is notatetendod with any dingetous corrifquences. 1. Boopiafter lifti out on thy travelo, ofe of the tradin whom I accompanied, complained of a siolent gonorr-

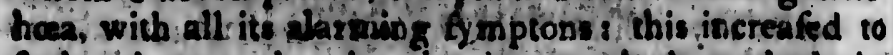
fuch a degree, that by the time we bad rexched the cowniof the Wianebegoet, be was anable to travel: Having mada his complaint know ri so one of the chiefs of that tribe, he told him rot to be uneafy, for he would engage that by the following his advice, he hiould be 2 : ble in a ferr daje to purfue his jourtiey, and in a little

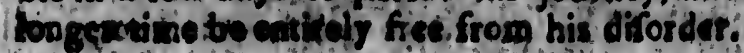


mas they ans cer: bot think

uples, for tare able tion, or iscaufed. thisy and te expect.

fies annu. is amaz: notwith. moifture

hat contieffruetive have otiill remains Ditemark, mong the Twas alfo nore wetzunce that of nations opeans, or thi it ; but ge of fucti nimunicu. equences: the tradien nt gonorrcreafed to ached the to travel: the chiefs whe would hould be a. Lin a tieth

The chief had no fooner faid this than he prepared for him a decoction of the bark of the roots of the prick. ly afh, 2 tree fearcely known in Englat,d, but which grows in great plenty throughout North Americs, by the ufe of which, in a few days he was greatly recover. ed, and having received directions how to prepare it, in 2f fortnight after his departure from this place, perceiv. ed that he was radically cured.

If from exceflive exercife, or the extremes of theat of cold, they are effected, with pains in their limbs or joints, they fearify the parts affected. Thofe nations who have no commerce with Europeans do this with a Tharp flint; and it is furprifing to fee, to how fine a point they have the dexterity to bring them ; a lancet can farcelly ex. ceed in Tharpnefs the influments they make of this un. malleable fubitance.

They never can be convinced a ferfon is ill, whill the has an appetite, but when he rejects all kinds oi ncurifiment, they confider the difeafe as dangerous, and pay great attention to it and during the continuance of the diforder, the phy fician refufes his patient no fort of food that he is defirous of:

Their doctors are not only fuppoted to be tailled in the phyfical treatment of difeafes, but the common peo ple believe that by the ceremony of the Chichicove uf: vally made ufe of, as before defcrited, they are abl to gain intelligence from the fpirits, of the caufe o whe complaints with which they are aflicted, and are there. by the better enabled to find remedies for them. They difcoyer fomething fupernatural in all their difeafes, and the phyfic adminittered mult invariably be aided by these lupertitions:

Sometimes a fick perfon fancies that his diforder a. rifes from vitcheraft; in this cafe the phy fician or jug. ter is confulted, whics, ufter the ufual preparations, gives lis opinion on the Rate of the difeafe, and frequently finds fome means fir his cure, But notwithftanding the Indian phyficians al ways annex thefe fuperititious ceremonies to their prefcriptions, it is very, certpin, as I iave already obferved, that they exercife thcir art by T. 
principles which are founded on the knowledge of $f \mathrm{~m}$. ples, and on the experience, which they acquire by an indefatigable attention to their operations.

The following fory, which I receired from a perfon of undoubted credit, prores that the Indians are not onily able to reafon with great acutenefs on the caufes and fymptons of many of the diforders which are attendant co human nature, but to apply with equal judgment proper remedies.

In Penobfcot a fettlement in the province of Maine, in the northeaft parts of New England, the wite of a folcher was taken in labor, and notwithftanding every neceflary affiftance was given her, could not be deliver. cd. In this fituation the remained for cwo or three days, the perfons round her expecting the nest pang would put an end to her exiftence.

An Indian woman, who accidentally pafted by, heard the groans of the unhappy fuffecter, and enquired from whence they proceeded Being made acquainted with the defperate circumflance attending the cafe, the toid the informani, that if the might be permitted to fee the perfon, the did not doubt but that the thould be of great Service to her.

The furgeon that had attended, and the midwife, whe was hen prefent, having given up every hope of preferv their patient, the Indian woman was allowed to make ufe of any methods the thought proper She ac. cordingly tonk a handkerchief; and bound it tight over the nole and mouth of the Foman i this imnediately brotight on a fuffocation; and frem theifruggles that confequently enfued, the ras in few feconds delivered. Thic mcreet this was atchicved, and time enough to prevent any fatal effe $A$, the handkterchief tas taken $c$ ff. lic lerg fiffering patient ilus liaply relieved ficm her rains, fcon aftel perfeclly recoresed, to the aftonillirent if all itofe who had becn witneffes in ber defperate fito nitisn.

Ile rcafon giten by the Irdian for this liazardcus bicis.cd of proccedirg vias, that defreraie difcrders re Givi defferate remedies llat as die obftricd the ex.

or $\mathrm{rnt}$

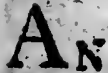

his hut, in the 6 tricles. almoft bis fate no Jong the gre: If.ho funeral dien fin be thin! and iffu which is to prong Afte: the $\mathrm{cum}$ painted. 1:in, pl. by his angues - warrior Cunoing wemely "Yor its uftia vithout povier 
eof fim re by an

a perfón not orily ares and attendant jưdgment

of Maine, wife of a ing every e deliver. iree days, ig would

by, heard ired from ored with Ane toid to fee the of great

vife, who e of preHlowed to She ac. tight over nediately ggles that delivered. encugh to raken $c$ ff. d ficm her onilliment freiate lito

liazardcus fcrders ro. ed tie ex. ortions of nature wera not fufficiently forcible to effea the defired confequence, the thought it necellary to aug. ment their force, which could only be done by fome mode that was violent in the extreme.

\section{CHAP TER XV.}

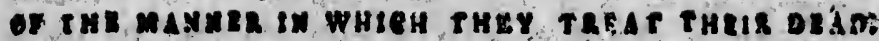

A his hut, with the fame refolution he has ofien faced him. in the feld. - His indifference relative to thisimportant article which is the fource of fo manj appreherifions to almolt every other nation. is truely admirable. When. bis fate is pronounced by the phyfician, and it remains no longer uncertain, he barangues thofe about him with the greatelt compofure.

If ho is a chief and has a family, he makes a kind of funeral oration, which he concludes by giving to his chil. dien fich advice for the, regulation of their conduet as he thinks neceffary. He then takes leave of his friends; and iflue out orders for the prepatation of $a$ fealt, which is defigned to regale thofe of his tribe that come to pronounce his vlugium.

After the breath is departed, the body is dreffed in the fume attire it ufually wort whill living, his face is painted, and be feated in an erest poffure on a mat, or Akin, placed in the middle of the hut, with his weapons bj his fide: His rulitions being feated round. each har. angues in turn the deceafed; and if he has been a great: - warrior, recounts his heroic actions nearly to the fol. Cuwing purport, which in the Indian language is exwemely poetical and pleafing:

"You Atill ft anong us, Brother, your perfon retains its uftial refémblance, and continues fimilar to ours, without any vilible deficiency, except that is has lolt the pover of actica. But whither is that breach flown 
Which a few hours ago fent up r.nole to the great Spir. it ?. Why are thofe lips filent, that larely delivered to us crpretife and plealing language? why are thofe feet motionlers, that a thort time ago were fleeter than the deer on yonder mountains ? why ufolefs hang thofe arms that could climb the talleft tree, or draw the toughelt bow? Alas ! every part of that frame which we lately beheld with admiration and wonder, is now become as inanimate as it was three hundred winters ago. We will not, however, bemoan thee' is if thou walt forever loft to us, or that thy name would be buried in obliva ion : thy foul yet lives in the great countes of fpirits, with thofe of thy nation that are gone before thee; and though we are left hehind to perperuate thy fame, wo thall one das join thee sctuared by the refpect we bore the whila living, we now come to tender to thes the lalt act of kindnefs it is in nur power to beftow ; that thy body might not lie neglected on the plain, and be. come a pray to the beafts of the field, or the fowls of the air, se will take care to lay it with thofe of thy predeceffors who are gone before thee; hoping at the fame time, that thy fpirit will feed with their fpirits, and be ready to receive ours, when as alfo thall arrive at the great country of fouls."

In thort peeches fome what fimilar to this dues every chief fpeak the praifes of his departed friend. Whea they have fo done, if they happen to be a great diftance from the place of interment, appropriated to their tribe, and the perfon dies during the winter featon, they wrap the body in Reins, and lay it on a high ffage built for this purpole, or on the branches of a large tree, till the fpring ar rives. They then, after the manner de. feribed in my journal, carry it, together with all thofe belonging to the fame nation, to the general burial place, where it is interred with fome other ceremonies that $f$ could not difcaver.

When the Naudoweffies brought their dead for inter a ment to the great cave, I attenupted to get an infight into the remaining burial rites s but whether it was on acc ount of the liench which arofe from fo many bodies, the weather being then hot, or whether they chofe to

Leep th not dif my cuil Afte belong: ics as 1 pliflinen at a di it impo burn th them iil As: employ of fpiri tood by tend wi regions bury $w$. other w doubt $x$ the nea orname or fluff domeit: fons.

The an app and ho At in th vals bet

One Nausidós ed in 1 men, to of their of whic greater. theirile rery ple

Whi was ad 
teep this part of their cultoms fecret from me, I could not difcover, I found, however, that they confidered iny curiofity as ill timed, and therefore I withdrew.

After the interment, the band to which the perfon belongs, take caro to fis near the place fuch hieroglyph. ics as thall thew to future ages bis merit and accomplifhorints. If any of thefe people die in the fummer, at a diftance from the burying ground, and they find it impoflible to remove the body before it putrefees, they burn the fleth from the bones, preferving the latter, bury them in the mannor defcribed.

As the Indians believe that the fouls of the deceafed employ themfelves in the fame manner in the country. of fpirits, as they did on earth, that they acquire their: tood by hunting, and have there, alfo, enemies to contend with, they take care that they do not enter thofe regions defencelefs and unprovided ; the confequently bury with them their bows, cheir arrows, and all the other weapons ufed either in hunting or war. As the) doubt not bat they will likewife have occafion both for the neceffaries of life, and thofe things they efteem as ornaments, they ufually depolit in their tombs fuch Ikins or fluffs as they commonly made their garments of, domeftic utenfils, and paint for ornamenting their perforis.

The near relations of the deceafed lament his lofs with an appearance of great forrow and ang uilh; they weep and howl, and make ufe of many contortions, as they Git in tho hut or tent around the body, when the inter. vals betwees the praifes of the chiefs will permit.

One formality in mourning for the dedd among the Naudouweffres is vei y different from an y mode I oblery. ed in the other nations through which I paffed. The men, to thew how great their forrow is, pierce the fleth of their arms, above the elbows, with, arrows; the fcars of which I could perceive on thofe of every rank, in a greater or lef's degree, and the women cut and gald their legs with . Parp brokeri flints, till the blood flows very plentifully:

Whild I remained among them, a couple whofe tent was adjacent to mine, loft a fon of about four years of r. 2

is bodies, chofe to 
age. $T$ he parents were fo much affeeted at the death of their favorire child, that they purfued the ufual teflimonies of grief with fuch uncommon rigor, as through the sreight of forrow and lols of blood, to occafion the death of the father. The woman who had heretofore been inconfolable, no fooner faw her hufband expire, than the dried up her tears, and appeared cheerful and réfigned.

As I knew not how to nccount for fo extraordinary a tranfition, I took an opportunity to alk her the reafon of it : telling her at the fame time, that I fhould have imagined the lofs of her liubland would rather have oc. cafioned an increafe of grief, than fuch a lúdden diminution of it.

She informed me, that us the clild was fo young when it died, and unable to fupport itfelf in the country of fpirits, both the and her hubind had been apprehen. five that its firuation wonld be far from happ ; but no foorer did the behold its faiher depart for the fame place, who not only, doved the child with the teriderent affec. tion, but was $\$$ good hunter, and would be able to pro. vide plentifully tor its fupport, than the ceafed to mourn. She added, that the now faw no redon to continue her tears, as the child un whom the doted, was hapy un. der the care and protection of a ford father, and the had only one with that remained ungratified, which was that of beigg herfelf with them.

Expretions for replete with unaffered tendernefs, and fentiments that would have done honor to a Roman matron, made an impretion on my mind gieatly in favor of the people to whom the belonged, and tended not 2 little to counteragt the prejudices I had hitherto cntertained, in common with every other traveller, of Indian infenfibility aud want of parental tendernefs.

Her fubfequent conduct confirmed the farorable 0 . pinion I had juf imbibed; and convinced me, hat, notwithltanding this apparent fufpenfion of her grief, fom particles of that reluctance, to be feparated from 2 beloved relation, which is implanted either by natuse or cuftom in every human heart, fill lurked in bers: I obferved that the went almolt every evening to the foot

of the $t$ band at of her' $t$ tive $\mathrm{mc}$ tion of 1 been $f_{p:}$ whilt $\mathrm{n}$ an inita be furpe

"if $\mathrm{t}$ rould: in thy hanc ed to the have dr. maraus 1 neryous falo, or I Thou we kept pia What fee faid an father ha ment 1 bevail t the great

the 1 ance of $t$ In fome faces, anic ly covere I'his feve fome rela for fever. recollecte tions, eve howi fo 2 fometinge for fever: occuried, thofe of them. 
he death ual teftiithrough infion the eretofore id expire, erful and

ordinary he reafon Juld have r have oc. den dimi-

fo young de country appretien. i but no ame place, areft affec. sle to pro. to mourn. timue her happy un. and the d, which

rnefs, and a Roman atly in fa. nd tended d hitherto aveller, of lernefs. Forable 0 . mie, shat, her grief, ated from bj nature in bers: I o the foot of the tree, on a branch of which the bodies of her hus. band and child were laid, and after cutting off a lock of her hair, and throwing it on the ground, in a plaintive mournful fong bemoanyed its fate. A recapitula. tion of the aetions he mighc have performed, had his life been fpared, appeared to be her favoritc theme; and whilt The foretold the fame that would have attended. an initation of his father's virtues, her grief feemed to be furpended:

"If thou hadit continued with us, my dear fon," would the ory, "how wsll wnuld the bow have become thy hand, and hpw fatal would thy arrows have prov. ad to the enemies of our utnds 1 hon wouldit often have drank their blood, and eaten their flesh, and nu. marnus haves vould have rewarded thy toils. With a nervous arm wouldit tho have feized the wounded bif: falo, or have combatect the fury of the enraged bear. Thou would have overtaken the f ying elk and nave kept puce on the mountain's brow with the fieetelt deer. What feats might thou not have performed, had thou Atid among us till age had given thee frength, and thy fatlier had initruted thee in evory Indian accomplith. ment In' terms like thefe did this untatored favage bewail the lofs of her fon, and frequently would he pats: the greateft part of the night in the affectionate employ.

The Indians in general are very Atrict in the oblerv. ance of their laws relative to mourning for their dead. In fome nations they cut off, their his, blacken their faces, and fit in an-ereat pofture, with their hed ds clote. ly covered, and depriving themfelves of every pleafure. 'this feverity is continued fo. feveral months, and with fome relaxations the appearine is fometimes kept up for feveral years. I was told that when the Naudowelfiesrecollected any incidents of thie lifyes of deceafed relations, even after an interval of ten years, they vould howl to 28 to be heard at a great difance. They would fometimes continue this prov of refpect and affection for feveral hours and if it happened that the thought occuried, and the noife was begun towards the evening, thofe of their tribe who were at hand would joiv with them. 
1 HE charaeter of the Indians, like that of other Lideratio

We if uncivilized nations, is compofed of a mixture of ferocit ty and gentlenefs. They are at offee guided by paftions and appetites, which they hold, in common with the ferceft beafts that inliabit their woods, and are poffefled of virties which do Jonor to human nature.

In the following eftimate I thall endeavor to forget on the one hand the prejudices of Europeans, who ufis. ally anvex to the word Indian, epithets that ate difgrace. ful to human nature, and who view them in no other light than as favages and canibals, whilf with equal care I aroid my particlity towards them, as fome muft paturally arife from the farorable reception I met with during my Aar among them.

At the fame time I thall confino my remarks to the mations inhabiting the wefern regions, fich as the Nau.

- doweftes, the Ottagaumies, the Chippeways, the Win: nebagoes, and the Saukies i for as throughout that di. verfity of climates, the extenfive continent of America is compofed of, there are people of different difpofitions and various characters, it would be incumpatible with my prefent undertaking to treat of all thefe, and to give a general viev of them as a conjunttive body.

That the Indians are of a cruel, revengeful, inexora ble difpnfition, that they will watch whole days unmind ful of the calls of nature, and make their way through pathlef and almoft unbounded woods, furbfifting only on the fcarity produce of them, to purfue and reveng. themfelves of an enemy , that the piercing cries of fuch as unhapily fall into their hands ind receive a diabolical pleafure fr om the ortures the inflie on their prifoners, I readily giant, but let us loo, on the reverfe of this terrifying picture, and we $\mathrm{Ih}$. Fnd them temperate both in their diet and rotations ff

whom 1 their ad, them of fence.

Incon lers, all c can alfert. with whic ter a long from cult the claims the little A ter, of the the imma point, an the mo of 6.

Acculto Mips, they in the drea yature, oident, nev Whough rovifion $\mathrm{r}$ iftances prfuit of Vies.

If they pery adva bir counc vvering th eight at ih a more : pezetrat 
mut be remembered that I fpeak of thofe tribes who. bave little intercourfe with the Europeans) that they witthand, with unexampled patience, the attacks of hunger, or the inclemency of the feifons, and efteem the gratification of their appesites but as a fecondary confideration.

We Pall likewife fee them focial and humane to thof whom they confider as their friends, end even to their adopted enemies; and ready to partake with them of the laft morfel, or to rifk their lives in their de. fence.

In contradiction to the report of many other travel. lers, all of which have been sindured with prejudice, 1 can affert, that notwithitanding the apparent indifferencewi h which an Indian meets his wife and children af ter a long abfence, an indifference proceeding rathes from cuftom than infenfibility, he is not unowindful of the claims either of connubiad or parental tendernels : the little ftory I have introduced in the preceeding chapter, of the Naudoweffie woman lamenting her child, and the immature death of the father, will /elucidate this point, and enforce the affertion much better than the moit fuidied arguments I can make ufo

Accuftomed from their youth to innumerable hand. Thips, they foon become luperior to 2 fenfe of danger, ar the dread of death, and their fortitude, implanted by nature, and nurtured by example, by precept and acaident, never experiences, a moment's allay.

Though Alothful and inactive whilf their tor of provifion remains unexhaulted, and their foes are at a Hitance, they are indefatigable and perfevering in purfuit of their game, or in circumventing their ene. ties.

If they are artful and defigning, and ready to take very advantage, if they are cool and deliberate in hiir councils, and cautious in the extreme either of dif: overing their fentiments, or of revealing a fecret, ther hight at the fame time boant of poffefling qualifications: a more animared nature, of the fagacity of a hound, he penetrating light of a lynx, the cunning of the fox, prtures thes thet us lool d. we That cotations fi

1, inexora: s unmind Th through te rever amoved the heir hands (a) 
the agility of a bounding roe, and the unconquerable fercenefs of a tiger.

In their public charaeters,as forming a part of a com. munity, they poffefs an attachment for that band to which they belong, unknown to the intrabitants of any other country. They combine, as if they were actuated only by one foul, againt the eaemies of their nation, and banith from their minds every confidetation oppofed to this

'They confalt without unneceffars oppofition, or with. out giving way to the excitements of enry or ambition, on the meafures neceflary to be purfued for the deltruc. tion of thofe wha have drawn on themfelves their dif pleafure. No felfor views ever influence their advice, or obftruet their confultations. Nor is it in the porver of bribes or threats to diminilh the love they bear their country.

The honor of their tribe, and the welfare of their na. tion, is the firt and mol predominant emotion of their hearts and from hence proceed in a great meafure all their virtues and their vices A luated by this; they brave every danger; endure the molt exquifite torments, and expire triumphing ia their fortitude, not as a perfonal qualification, but as a national charac ceriftic:

From thence alfo flow that infatiable tevenge towards thofe with whom they are at warjand all the confequent horrors tl,at difgrace their napne. 't heir uncultivated mind being incapable of judging of the propriety of an ation; in oppoltion to their paffions which are totally intenfible to the controls of reafon or humanity, they know not how to keep their fury within any bnunds, and confequently that courage and refolution, which would otherwife do them honor, degenerates into a fap. age ferocity.

But this thort differtation muft fuffice s the limits 0 my work will not permit me 10 treat the fubject more copioutly, or to purfue it with a logical regularity. Ib obforvatinns already madé by mv readors on the pro ceding pages, will, I crult, render it unneceffiry is a b stem they will be enubled to form a tulerable juft ide

of the en, the howevi a trues pople, late, $t$ Githoul

or

$\mathrm{THF}_{\mathrm{HE}}$

Americ: ft of fu pois to Algonki eilt, an Dhe or tho inh ador n's Id, as to mad But of ie molt be Chic r to the i, with $\checkmark$ Hudf ribes, $\mathrm{fp}_{\mathrm{p}}$ otwith? It will y the Is curfion dalified alefs thi At pro 
conquerable

urt of a come hat band to ants of any iere acturated heir nation, usion oppofed

tion, or with. or ambition, $r$ the deltruc. tes their dif their advice, in the power ey bear their

of their na. emotion of 1 in a great A clunted hy molt exquifits ir fortitude, cional charace

engo towards beconfeyuent uncultivated opriety of an sh are tntally manity, thes. any bounds, lution, which ses into a far.

the limits 0 - fubjest more gularity. Ib so on the pre ceflury i as b) able jus ides w the people I have been defcribing: - Experience teach. ts, that anecdotes, and relations of particular events, however trifling they, might appear, enable us to form a truer judgment ot the manners and cuftums of a people, ana are much more declaratory of their real late, than the molt fudied and elaborate difquifition bithout thefe aido.

\section{CHAPTER XVII.}

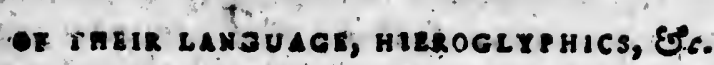

17

1 HE principal languages of the natives of North America may be divided into four claffes, as they conift of fuch as are made ufe of by the nations of the Iro. poois towurds the eaftern parts of it, the Chipeway or Algenkins to the north weft; the Naudoweflies to the seit, and the Cherokees, Chickafa ws; ac to the fouth. Die or other of thefe four are ufed by all the Indians wo inhabit the parts that lie between the crialt of Lab. ador north, the Fioradas fouth, the Atlantic ocean eaft, ind, as far at can judge from the difcoveries hiththe -made, the Pacific ocean on the welt.

But of all thiefe the Chipeway tongue appears to be the mott prevailing , it being held in tuch efteem, that the Chicfs of erery tribe, dwelling about the great lakes, If to the wellward of thefe on the banks c! the Mifilip. i. with thofe as far fouth as the Ohir, and as far north 6 Hudfon's bay . confifting of more than thirty different tibes, fpeaking this language alone in their councils, otwithfanding each has a peculiar one of their own. It will probably in time become niverfal añong II the Indian nations; as none of them attempt to mate seurfions to any great / diftance, or are confidered as dalified to carry on any negociation with a diflant band, mlefs the have acquired the Chipeway tongus. At prefent, lecides the Chipeways, to whom it is ante 
ural, the Ottawaws, the Saukies, the Ottagaumies, the Killifinoes, the Nipegons; the bands about Lake Le Pluye, and the remains of the Algonkins, or Gens de Terre, all converfe in it, with fome little variation of a dialect; but whether it be natural to thofe nations, or acquired, I was not able to difcover. I am, however, of opinion that the barbarous and uncouth dialect of the Winnebagoes, the Mencmonies, and many other tribes, will become in time tctally extinct, and this be adopted in its ftead.

The Chipeway tongue is rot encumbered with any unneceffary tones or accents, neither are there any words in it that ase fuperfluous; it is alfngary to pronounce, and much more copious than any other Indian language.

As the Indians are unacquainted with the pulite arts, or with the fciences, and as they are frangers to cere. mony, or compliment, they neither have-nor need an infinity of words wherewith to embellith their difcourfe. Plain and unpolithed in their manners, they only make ufe of fuch as fervi to dencminate the neceffaries or conreniences of life. and to exprefs their, wants, which is a ftate of nature can be but few.

As the Indians are not acquainted with letters, it is very difficult to convey with precifion the exact fourd of their words.

Although the Indians cannot communicate tbeir ideas by writing, yet they form certain hitrogly phics, wlrich, in fome meafure, ferve to perpetuate any extraordinary tranfaction, or uncommon everit. Thus when they are on their excurfions, and either intend to proceed, or have been on any remarkable enterprife, they peel il:c bark from the trees which lie in their was, to give inteiligence to thole parties that happen to be at a diliance; of the path they mult purfuo to ovcrtake them.

The following inflance will convey a more perfal idea of the methods they make ufe of on this occafion, than any exprefions I can frame.

When I left the Miffifippi and proceeded up the Chip. eway Kiver, in my way to lake Superior, us selafed i. my journal, my guide, who was a chief of the Chipc ways that dwell on the Oxtowaw lake, near the heads of

the $r$ of th ually fore fome

He a rive their exprel gaumi thins, with a fymbo furthe which defign! my Fr and ro fignific sppear The - Alies, ly intel receive town o Englif Cbiper the $\mathrm{Ch}$ my, th had th their na

Som armori nefs, an I never the fyser 
aumies, the it Lake Le ir Gens de iriation of a nations, or n, howerar, lialeet of the other tribes, be adopted

d with any re any words pronounce, an language. je pulite arts, yers to cere. nor need an eir difcourfe. ey only make fearies or con5 , which is a

letters, it is e exiaf found

ate thẹir ideas phics, wiricht, extraordinary when they are beesd, or have peel il:c bart pe inteiligence ittance, of the

re perfact idea occafion, than d up the Chip. , us selared i. of the Chirc. ar the heads of the river we had juft entered, fearing that fome parties of the Naudoweffies, with whom his nation are perpetually at war, might accidentally fall in with us, and bes fore they were apprifed of $m y$ being in company, do us fome mifchiet, he took the following fleps.

He peeled the bark from a tree, near the entrance of a river, and with wood coal,mixed with bear's greafe, their ufual fubltitute for ink, made in an uncouth, but expreffive manner, the figure of the town of the Otta. gaumies. He then formed io the left $a$ man dreffed in atins, by which he intended to reprefent a Naudoweffie, with a line drawn from his mouth to that of a deer, the fymbol of the Chipeways. After this he depictused Atill further to the left a canoe as proceeding up the river, in which he placed a man with a hat on ; this tigure was defigned ro reprefent an Englifhman, or myfelf, and my Frenchman with a handkerchief tied round his head and rowing the canoe; to thefe he added feveral other lignificant emblems, among which the Pipe of Peace appeared painted on the prow of the canne.

The meaning he intended to convey to the Naudows - fires, and which I doubt not appeared to them perfoctIy intelligible, was that one of the Chipeway chiefs had received a fpeech from fome Naudowetlie chiefs, at the town of the Ottagaumies, defirmg him to conduct the Englimman, who had lately been among them, up the Chipeway river; and that they thereby required, that the Chipewdy, notwithftanding he was an arowed ene. $\mathrm{my}$, thould not be molefted by them on his paffage, as he had the care of a perfon whom they efteemed as one of their nation.

Some authors have pretended that the Indians have armorial bearings, which they hlazon with great exastnefs, and which difting uifh one nation trom another; but I never could obfes ve any other arms among them than the fymbols already defcribed. 
CHAPTER XVIII.

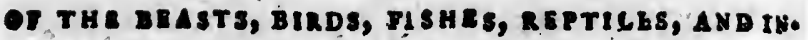
SFCTS, WHICH ARE FOUND IN THE INTERIOR

PARTS OI NORTH AMFRICA.

infive, $u$

tom a w

dog wil remely igheft tr ers their

is conf

that of

F thefe 1 thall, in the firft place, give a catalogn. and afterwards a defcription of fuch only as are eithe peculiar ta this country or which differ in fome materie point from thofe that are to be met with in other realm

O) THE BEASTS.

The Tiger, the Bear, Wolves, Foxes, Dogs, the $\mathrm{C}_{2}$ of the mountain, the Wild Cat, the Buffalo, the Det the Elk, the Moofe, the Carrabou, the Carcajou, th Skunk, the Porcupirie, the Hedghog, the Woodchal the Racoon, the Martin, the Filher, the Mufquath, Squi rels, Hares, Kabbits, the Mole, the Weezel, the Mouf the Dormoufe, the Beaver, the Otter, the Mink, an - Bats.

The TIGER of Ametica refembles in thape thofeo Africa and Afia, but is confiderubly fmaller. Nor doe it appear to be fo fierce and ravenous as they are. Th color of it is a darkith tallow, and is entirely free froi fpots. I faw one on an ifland in the Chipeway rive of which I had a very good view, as it was no zreat di tance from ine. It fat up on its hinder parts like a do and did not feem either to be apprebenfive of our af proach, or to difcover any ravenous inclinations. It howerer very feldom to be met with in this part of th world.

The BEARS are very numerous on this continen but more particularly fo in the northern parts of it, $a R$ contribute to furnilh both fond and beds for almoft er ry Indian nation. 2 hofe of America differ in many $x$ peds from thofe either of Greenland or Ruflia, they b ing not only fome what fmaller, but timorous and ino

ad befic of on loys - 'I int themi beafure

tear is di ade in $h$ oots of th bey Atop rom the eather. $\mathrm{c}$ bey do $n$ ofed to $t$ ithout, : ulk

'The W hole whi hey have ecies, a jes; no 0 raveno ttack a tells of th 3 they 0 etrible $n$ $f$ which ag to a. There hich di rown, $t$ ire foun iful, the The D 
5, $\triangle$ N B IY TERIOR

2. catalogu 2s are eithe [ome materia other realm

Jogs, the $\mathrm{C}$ ? lo, the Dee Carcajou, th Woodchuck Cquath, Squi It, the Mouf? he Mink, an

Thape thofe o er. Nor do. acy are. $\mathrm{Th}$ ely free frou ipeway rive is no zreat di arts like a do: ve of our ap ations. It his part of th

this continen jarts of it, an for almoft er er in miany re Sulfa, they b rous and inol nfive, unlefs they are pinched by hunger, or fmarting som $a$ wound. The fight of $a$ man terrifies them, and dog will put feveral of them to flight. They are exremely fond of grapes, and will climb to the top of the igheft trees in quett of them. This kind of food ren. lers their fleth exceffively rich, and finely flavored; and is confequently preferred by the Indians and ttaliers s that of any other animal. The fat is very white, nd befides being fweet and wholeforme, is poffeff 1 of one valuable quality, which is, that it never loys The inhabitants of thefe parts, conftantly anint themfelves with it, and to its sfficacy they in 2 great peafure owe their agility. . The feafon for hunting the ear is during the winter; when they take up their n. ode in hullow trees; or make themfelves dens in the bots ut thofe that are blown down, the entrance of which hey flop up with branches of fir that lie feattered about. from thefe retreats it is faid they Mir not whilf thi seather continues fevere, and as it is well known that hey do not provide themfelves with food; they are fupofed to be enabled by nature to fubfit for fume months ithout, hind during this time to continue of the firme wilk

The WOLVES of North A merica are much lefs than tofe which are met with in oiker parts of the world. hey have, however, in common with the reft of their pecies, a wildnefs in their looks, and a tiercenefs in their yes; notwithflanding which, they are fir from being o ravenous as the European wolves, nor will they ever Itack a man, except they have accidentally fed on the left of thofe flain in battle. When they herd together, st they often do in the winter, they make 2 hideous and etrible noife. In thefe parts there are two kinds; one f which is of a fallow color; the other of a cun, iaclin. og to a black.

There are two forts of FOXES in North America. hich diffor only in their color, one being of a redith frown, the other of a gre , thofe of the latter kind that re found near the river Mifflippi, are extremely bedu. iful, their hair being of a filver grey.

The DOG Seroployed by the Indians in hunting appeas 
to be all of the fame fpecies ; they carry thotr ears ered, and greatly refemble a wolf about the head. They are exceedingly ufoful to them in their hunting excurfions, and will attack the fierceft of the game they are in pur. fuit of. 'They are alfo remarkable for their fidelity to their mafters; but being ill fed by them, are very trou. blefome in their huts or tents.

'The CAl' of the Mountain is in thape like a cat, only much larger. The hair or fur refembles alfo the fsin of that domelic animal ; the color, however, differs, for the former is of a reddifh or orange calt, but grows lighter near the belly. I he whole fkin is beautified with black fpots of different tigures, of which thofe on the back ure lorg, and thofe on the lower parts round. Un the ears thore are black firipes. 1 his creature is nearly as ferce ab a leopard, but will feldoin attack a man.

itie BUFF.ILO, of which there are amazing num. ters in the e parts, is larger than an $0 x$, has Thort black horris, with a large beard under his chin, and bis head is fo fuil of hair, that it falls over his ejes, and gives him a frightiul look. There is a bunch on his back which begiris at the haunches, and increafing gradually to the thoulders, reaches on to the neck. Bnth this excrefcence and its whole body are covered with long hair, or rath. er wool, of a dun cr moufe colnr, which is exccedingly valuable, efpecially that on the fore part of the body. Its head is larger than a bull's witl a very thort neck; the breaft is broad, and the body decreafes towards the iuttocks: 'Thefe creatures will run away at the fight of $a$ man, and a whole hera will make off when they perceive a tingle dog. The fleth of the buffalo is excellent food, its hide is extremely ufeful; and the hair very proper for the manufacture of various articles.

There is but one fpecies of DEEK in North Ameri. 0 , and thefe are higher and of a. Almmer make than thofe in Europie. Their thape is nearly the fame as the European, their color of a deep faltow, and their horns very large and branching. I he decr is the fwifell on the American plains, and they herd together as they do in octior conntriez.

'I'he ] balk eqi deer, on than thi grey, an difh calt as that , a prodig perfon's are not teeth or of thore Atat, and are roun horns ev gut the Notwith nature $\mathrm{l}$ - deer. xs that $c$ on mofs The the hor: the Aten they bra ture alf are vers feer, an long, it: noftrils into the light gi for thou riginal of dige lip, wh a great marrov a rich : leather The p? 
arsered, They are xcurfions. e in pur. idelity to ery trou.

cat, only fo the Akin $r$, differs, put grows beautified i thofe on rts round. creatute is n attack a

zing num. hort black d his head 1 gives him lack which ally to the xcrefcence ir, or rath. xceedingiy the body. lort neck; owards the he fight of they per. s excellent hair very s.

th Ameri. nake than ame as the their horns iwif:el on as they
'The ELK greatly exceeds the deer in fize, being in balk equal to a horfe. I Its body is thaped like that of a deer, only its tail is remarkably thort, being not more than three inches long. The color of its hair, which is grey, an 1 not unlike that of a camel, but of a more red. difh calt. is nearly three inches in length, and as ccarfe: as that of a horfe. The horns of this creature grow to a prodigious fize, extending fo wide that two or three perfons might fit between them at the lame time. 'I'hey are not forked like thofe of a deer, but have all their teeth or branches on the cuter edge. Nor dues the form of thofe of the elk refemble. a deer's, the former being fat, and eight or ten inches broad, whereas the latter are round and confiderably narrower. They fhed their horns every year in the month of February, and by Augult the new onesare nearly arrived at their full growth. Notwithlanding their fize, and the means of defence nature has furnilhed them with, they are as timorous as - deer. Their tkin is very ufeful and will drefs as welk as that of a buck. 'They feed on grafs in the fummer, on mof's or buds in the winter.

The MOOSE is nearly about the fize of the elk, and the horns of it are almcit as numerous as that animal's; the ftem of them, however, is not quite fo wide, and they bra nch on both fides like thofe of 2 deer. I'his creature alfo heds them erery year 'Though its hinder parts are very broad, its tail is not above an inch long. It his feer and legs like a camel; its head is about two leet long, its upper lip much larger than the under, and the noftrils of it are fo wide that a man might thrult his hand. into them a confiderable way. The hair of the moole is light grey, mixed with a blackifh red. It is very elaftic, for though it be beaten ever fo long, it will retain its 0 . riginal thape. 'I he felh is exceeding good food, eafy of digeltion, and very nourifhing. : The nufe or upper lip, which is large and loole fiom the gums, is efteemed. a great delicacy, being of a firm contiftence, between marrow and grifle, and when properly dreffed, affords a rich and luficious difh. Its hide is very proper tor leather, being thick and Aroag, yet foft and pliable: I'he pace of this creature is always a trot, which is fo $\checkmark 8$ 
expeditious, that it is exceeded in fwiftneis but by few of its fellow inhabitants of thefe woods. It is general. Iy found in the forens, where it feeds on mofs and buds. I'bnugh this creature is of the deer kind, it never herds at thofe do, Moft authors confound it with the elk, deer or carrabiou, but it is a fpecies totally different as might be difcovered by' attending to the defcription I have given of each.

The CARRIBOU is not fo tall as the moofe, how. ever, it is fomething like it in thape, only rather more heavy, atd inclining to the form of an afs. The horns of it are not flat as thofe of the elk are, but round like tbofe of the deer; they alfo meet neaser together at the stremities, and bend unore vier the face than either thofe of the etk or moofe. It purtakes of the fwiftness of the dcer, and is with difficulty uvertaken by its pur. - fues. The fleth of it.likewife is equally as good, the tongue particularly is in high eiteem. The okin being: frooth and free fiom veins, is as valuable as thamoy. The CARCAJOU, which is of the cat kind, is a ter. rible enemy to the preceding four fpecies of bealts. Heoisher comes upon them fiom fome concealment unperceived, ur climbs up into a tree, and taking his Ration on fome of the branches, waits till one of them driven by an extrence of heat or culd, takes thelter under it : whev be falteus upon his neck, and opening the juguler vein, foon brings his prey to the ground. I his he is en. tbled to do by his long tail, with which he encircles the body of his adverfary; and the only means they have to thun their fate, is by flying inmediately to the sater; by this, method, as the carcajou bas a great diflike to that element, he is fometimes got rid of before he can effect his purpore.

The SKUNK is the moll extraordinary animat that the American woods produce. It is rather lefi than a polecat, and of the came fpeciés; it is therefore often miltaken for that creature, but is rerp diferent from it in many points. Its hair is long and thining, varicgated with large black and white fpots, the former moltly on the Phoulders and rump ; its tail is very bufhy, like that of the fox, part black, and part white like its bedr; it

lives ch dinary foon as dittance tile a $n$ that the ference almot $f$ over the French, Bete ''u: dafcribe creature of it fall greeable $v$ if any tollerabl your fig dreaded. fortid eff penetrati withitan and ro $r$ uraliits them the ies, neas water to ed the un hoorid $A$ great cas frequent] and goor carcafe, provifion tise ther name.

the $\mathbf{P}$ fize of : not fo his from tho length of 
by few general. nd binds. er herds elk, deer as might I I have

fe, how. her more lue horns und like er at the in eitber fwiftenefs its pur. nod, the in being: thamoy. l, is 2 ter. afts. Hle nt unper. is Ration $m$ driven inder it : ejugular. 5 he is en. ircles the hey have he vater; diflike to e be can

mat that fis than a ore uften $t$ from it aricgated holtly on like that badr; it lives chiefly in the wonds and hedges; but its extraordinary powers are oniy thew when it is purfued. As foon as he finds himfelf in danger, he ejests, to a great diltance from behind, a imali frean of water, of fo fub. tile a nature, and at the fame time fo powerfol imell, that the air is tainted with it for half a mile in circuns. ference ; and his purfuers, whether men or dogs, being almolt fuffocated wirh the ftench, are obliged to givo over the purfuit. On this account he is called by the French, Enfant du Diable, the Child of the Deril ; or Bete 'tuante, the Stinking Bealt: It is almof impofible to dafcribe the noifome effeets of the liquid with which this creature is fupplied by nature for its defence. If a drop. of it falls on your clothes, they are rendered fo difa. greeable that it is impolible ever after to wear them: ur if any of it enters your eyelids, the pain becomes intollerable for a long iime, and perhaps at laft you lofe. your fight. The fmell of the frunk, though thus to be dreaded, is not like that of a putrid carcafe, but a ftrong foetid effluvia of mufk, which difpleates rather from its. penetrating power than from its naufeoufnefs. It is notwithitanding confidered as conducive to clear the head, and ro raife the fpirits. This water is fuppofed by naturalilts to be its urine; but I have diffected many of them that I have thot, and have found within their bodies, near the urinal veffel, a fmall receptacle of water totally diltinet from the bladder which contain. ed the urine, and from which alone I am fatisfied the hourid Atench proceeds. After having takea out with great care the bag wherein this water is lodged, I have trequently fed on shem, and have found them very fweet and good ; hit one drop cuitred taints not only the carcafe, but the whole houfe, and renders every kind of provifions, that are in it, untiv for ufe. With great juftise therefore do the French give it fuch a diabolical. name.

the PORCUPINE of Americe is in bulk about the fize of a fmall doz, but is both fhorter in length, a.ad not fo high from the ground. It varies very much. from thofe of other countries both in its thape and the length of its quills. 'The former is like that of a fox, 
except the the head, which is not fo tharp and long, but refembles more that of a rabbit. Its body is cover. el with hair of a dark brown, about four inches long, greai p.urt of which are the thicknefs of a Araw, and are termed its quills. Thefe aré white, with black points, hollow and very ftrong, efpecially thofe that grow on: the back. The quills ferve this creature for defenfive weapons; and if they pierce the flefh in the leaft degree, they will fink quite into it, and are not to be ex. traeted without incilion. The Indians ufe them for boring their ears and noles, to infert their pendants, and alfo by was of ornament in their ftockings, hair, \&cc . befides which, they greatly efteem the flefh.

The WOODCHUCK is a ground an Imal of the fur kind, about the fize of a martin, being nearly fifteen inches long ; its body however is rounder, and its legs ihorter ; the fore paws of it are broad, and conftructed for the purpofe of digging holes in the ground, where it burows. like a rabbit; its fur is of a grey color, on the redith cat, and its fleth is tolerable food.

The RACDON is fome what lefs in fize than a beaver, and its feet and legs are like thofe of that creature, but flort in proportiun to its body, which refembles that of a badger. The thape of its head is much like a fox's, only the ears are thorter, more round and naked; and its hair is alfo fimilar to that animal's, being thick, long foft, and black at the ends. On its face there is a broad Aripe that runs acrols it, and includes the eyes, which are large. Its muzzle is black and at the end -roundith like that of a dog; the teeth are alfo fimilar tn thofe of a dog in number and thape ; the tail is long and round; with annular fripes on it like thofe of a cat; the fiet have five long Dender toes, armed with fharp olaws, by which it is enabled to climb up trees like a monkey, and run to tive very extremities of the boughs. It makes ufe of its fore feet, in the manner of hands, and feeds itfelf with them. The fleth of this creature is very good in the months of September and October, when fruit and nuts on which it likes to feed, are plenty.

The MARTIN is rather larger than a fquirrel, and fome what of the fame make; its legs and claws hower

er, ar and $\mathrm{rr}$ of aic biown ern $p$ much ered than is ii any The for the be a di the pro ing bus a Iarge fo mucl actly th of their it migh ture it Arustion jiece of and in $p$ on whes other fr winter part by main qu elt reafo fpring

Sil

Ansetic and the thofe of differ $\mathrm{fr}$ femble being $f$ with rec than the ruffet 8 inder $p$ 
d long, $s$ coveres long, aw, and : points, jrow on: lefenfive eaft de. 0 be ex. em for nis, and. $r$, \&ec . be-

f the fur fifteen its legs nfructed 1. where' olor, on

a bearer, iture, but is that of e a fox's, sed ; and ig thick, 2 there is the eyes, $t$ the end fimilar ?n 5 long and i cat: ; the' arp claws, - monkey, It makes and feeds $e$ is very ber, when lenty.

uirrel, and ws howev- $r$, are conflderably thorter. Its ears are thert, broad, and roundith, and its eyes thine in the night like thofe of a cat. The whole bnd $y$ is covered with fur of $a$ brownith tallow color, and forme in the more north. ern parts are bluck; the Rkins of the latter are of much greater value than the others. The tail is corered with long hair, which makes it appear thicker than is really is. Its fleth is fometimes earen, but is not i) any great elteem.

The MUSQUASH, or MUSK.RAT, is fo termed for the exquifite mulk which it affords It appears to be a diminutive of the beaver, being endowed with all the properties of that fagacious animal, and wants nothing but fize and ftrength, being not much bigger than a large rat of the Norway hreed, to rival the creature it fo much refembies. Was it not for its tail, which is ex. actly the fame as that of an European rat, the Atruatur of their bodies is fo much alike, efpecialy the head; that it might be taken for a fmall beaver. Like that creature it builds itfelf a cabin, but of a lefs perfect con. Aruction, and takes up its abote near the fide of fome piece of water. In the fpring they leave their retreats, and in pairs fubfilt on leaves and roots till fummer comes. on when they feed on Arawberries, I afpherries, and fuch other fruits as they can reach. At the approach of winter they feparate, when each takes up its lodging apart by itfelf in fome hollow of a tree, where they re. main quite unprovided with food, and there is the great. eft reafon to bulieve, fubfilt without any till the return of fpring

S(jUIRRELS. There are five forts of fnuirrels in Anerici; the red, the grey, the black the iariegated and the flying. The two former are exactly the fame as. thofe of Europe; the black are fomewhat larger and differ from them only in color; the rariegated alfo re femble them in thape and fgure, but_are very beantiful, being finely Ariped with white or grey, and fometimes with red and black The flying fquirrel is much lefs. than the European, being about five inches long, and of a ruffet grey or afh color on the back, and white on the under parts. It has black prominent eycs, like thofe of 
the moufe, with a long, flat, broad tail. By. a membrane on each fide, which reaches from its fore to its hind legs, this creature is enabled to leap from one tree to an. other, even it they ftand a confiderable diftauce apart; this loofe $\mathrm{fkin}$, which it is enabled to Atretch out like a fail, and by which it is buoyed up, is about two inclues. broad, and is covered with a fine hair or down. It feeds upon the fame provifions as the others and is enfi. ly tamed.

The BEAVER. This creature has been fo often treated of, and his uncommon abilities fo minutel $y$ def. eribed, that any further account of it, will appear unne. ceffary; however for the benefit of thofe of my readers who are not to well acquainted with the form and prop. erties of this fagacious and ufeful animal, I thall give a. concif defcription of it. The beaver is an amphibious quadruped, which cannot live for any long time in the water, and it is faid is able to exilt entirely without it, provided it has the convenience of fometimes bathing. itfelf. The largelt beavery are nearly four feet in length, and about fourteen or fifteeninches in treadth over the haunches; they weigh about fixty pounds. Its head is like that of an otter, but much larger; its fnout is pretty long, the eyes fmall, the ears fhort, round, hairy on the outfide, and fmooth: within, and its teeth very long; the under teeth ftand out of their mouths about the breidth of three fingers, and the upper half a finger, all of which are broad, crooked; frong and tharp; belides thofe teeth called the inciffors, which srow double, are let very deep in their jairs, and bend * the edge of an axe, they have lixteen grinders, right on each fide, four above and four below, directly. oppofite to each other. With the former they are able to cut down trees of a confiderable faze, with the lafter. to break the hardeft fubftances. Its legs are fhort, particularly the fore legs, which are only about five inches long; and not unlike thofe of the budger, the toes of the fore feet are feparate, the nails placed obliquely, and are hollow like quills ; but the hind feet are quite different, and furnilhed with membranes between the toes.

By t

to fv The and 1 of : th ing ered gethe of $\mathrm{p}$ : of $a$ eleve mild root near gradi the bi in $\mathrm{w}$ are $\mathrm{g}$ their proas orer 1 that inch, es, $g \mathrm{r}$ This little down, quarte manu produ merly have f the lon from ed wi fmall frong flamm the air inferio 
brane

hind

to an.

tpart ;

like a inclies.

n. It is enti.

o often

Iy def.

unne-

readers

d prop-

give a: hibious in the. hout it, báth.ing. feet in: breadth pounds. Fer ; its , round, ts teeth ouths 2 $r$ half a png and: , which hd bend grinders, direetly. are able: he lafter: ort, parre inches es of the ely, and. te differthe toes.
By this means it can walk though but flowly; and is able to fwim with as much eafe as any other aquatic animal. The tail has fomewhat in it the refemblance of $2 \mathrm{fih}$, and feems to have no manner of relation with the reft of the body, except the hind feet, all the other parts being fimilar to thole of land animals. The tail is cov. ered with a fkin furnifhed with fcales, that are joined to. gether by a pellicle; thefe fcales are about the thicknel's of parchment, nearly a line and a half in length, and of a heragonical figure, having fix corners; it is about cleven or twelve inches in length, and broader in the middle, wliere it is four inches over, than either at the toot or at the extremity. It is about two inches thick near the body, where it is almnit round, and grows gradually thinner and fiatter to the end. The color of the beaver is different according to the different climates in which it is found. In the mott northern parts they are generally quite black; in more tem perate; brown; their color becoming lighter and lighter as they ap. proach lowards the fouth. The tur is of two forts all over the body, except at the feet, where it is very. thort; that which is the longeft, is generally in length about an inch, but on the back it fometimes extends to two inches, gradually diminihing towards the head and tail. This part of the fur is harth, coarfe and Thining, and of little ufe ; the other part confifts of a very thick and fine down, fo loft that it feels almof like filk, atout three quarters of an inch in length, and is what is commonly manufactured. Caftor, which is ufeful in medicine, is produced from the body of this creature ; it was formerly believed to be its tefticles, but later difcoveries" have thown that it is contained in four bags, fituated in the lower belly. T woof which, that are called the fuperior; from their being more elevated than the others, ate filled with a foft, refinous, adhefive matter, wixed with fmall fibres, greyilh without, and yeliow within, of a Arong, difagreeable, and penetrating fcent, and very inflammable. This is the true caforeum; it hardens in the, air, and becomes brown, brittle, and ifriable. The inferior bags contain an uncluors liquor like honey ; the 
color of which is a pale yellow, and its odor fomewhat different from the other, being rather weaker and more difagreeable; it however thickens as it grows older, and at length becomes about the confiftence of tallow. This has alfo its particular ufe in medicine; but it is not $f_{0}$ valuable as the true caftoreum.

The ingenuity of thefe creatures in building their cabins, and in providing for their fubliftence, is truely wonderful. When they are about to chufe themfelves a habitation, they affemble in companies fometimes of :two or three hundred, and aíter mature deliberation fix on a place where plenty of provifions and all neceffaries are to be found. Their houfes are always fituated in the water, and when they can find weither lake nor pond adjacent, they endeavor to fupply the defect by Atopping the current of fome brook or fmall river, by. means of a caufewayor dam. For this purpofe they fet about fel. ling of trees, and they take care to chonfe out thofe that grow above the place where they intend to build, that they may fwim down with the current. Having fixed on thofe that are proper, three or four beavers placing themfelves round a large one; find means with their Atong teeth to bring it down. They alfo prudently contrive that it toall fall towards the water, that they may have the lefs way to carty it. After they have by a continuance of the fame labor and induftry, cut it in- proper lengths, they roll thefe into the water, and avigate them towards the place where they are to be employed. Without et.tering more minutely into the meafures they purfue in the confruetion of thoir dams, I thall only remark, that having prepared a kind of mortar with their feet, and laid it on with their tails, which they had before made ufe of to tranfport it to tt.e place where it is requifite, they confruct them with as much folidity and regula:ity as the mut expericrced work. men could do. The formation of their cabins is no lels amazirg. I hefe are either built on poles in the mid. dle of the (mall lakes they have thus formed, in the bank of a river, or at the extrtmity of feme point of land that advances into $a$ lake. I he figure of the $m$ is

tound

t) equ above to chn his pla ftrews fo as th bins at allow c fun prif for by ithed: Thefe? foft, fou the $\mathrm{l}_{2}$ to preff inftanc imals, tertain The and 8 from in $\alpha$ bed truizle fame, $b$ the lar ot ther iite thi mer is nor is otter of ith thai tikewif parts 0 North elofely It 8 bat in the pre fmells fonseti. 
fomewhat ar and more $s$ older, and llow. This it is not fo $^{2}$

ilding their e, is truely themfelves metimes of iberation fix Ineceffaries fituated in ke nor pond by Atopping means of et about fel. It thofe thiat build, that aving fixed vers placing with their - prudenily $r$, that they hey have by ry, cut it in. water, and e) are to be ely into the thoir dams, kind of mor. tails, which to the place ith as much cr.ced work. bins is no lefs s in the mid. med, on the me point of re of them is roundor oval, and they are fafhioned with an ingenuits equal to their dams. I wo thirds of the edifice ftands above the water, and this part is fufficieritly capacions to contain ejght or ten inbabitants. Each beaver has his place affigned him, the flods of which he curioufly ftrews with leaves, or fmall branches of the pine tree, fo as to render it clean and comfortable, and their cabins are all fituated fo contiguous to each other, as to allow of an eafy commurication- The winter never fui prifes thefe animals before their bafinefs is completed; for by the lattes end of September their houfes are fir. ithed. and their ftock of provifions is generally laid in. Thefeconfift uf fmall pieces of woud whofe texture is foft, fuch as the poplar, the afpin, or willow, \&c. which they lay up in piles, and difpofe of in fuch manner as to preferve their molfure. W,as 1 to enumerate every infance of fagacity that is to be difcuvered in thefe an. imals, they would fill a volume, and prove not only ens tertaining but inftructing:

The OTTER. This creature alfo is amphibions, Ind greatly refembles a beaver, but is very different from it in many relpects. Its bridy is neatly as long as 2 bentor's but confidetablv, lets in all its parts. The muzzte, eyes, and the form of the heid rie ntarly the fame, but the teeth are very inlike, for the otter wants the large incifots or nippers that a beaver has; inftead ot thefei all his teeth, without any dinination, are lhaped iite thofe of 2 don or wolf. Ithe hair alfo of the former is not half folong as that belonging to the latter, nor is the color of it exaetly the fame, for the hair of an bttet under the neck, ftomach and belly, is more groj. ith than that of a beaver, and in many other refpects it tikewife varies. This animal, which is met with in molt parts of the world, but in $r$ : uch greater numbers in North A merica, is very mifchievious, and when he is elofely purfued, will not only attack dogs but men:

It genei ally feeds upon fin, cfpecially in the fummor, bat in the winter is contented with the lark of trees, or the prodice of the fields Its Helh both taltes and inclls of fih, abd is not a liolifome font, livough it is fometimes eaten. throngh inecelfity. W 
The MINK is of the otter kind, and fublits in thl fame manner. In thape and fize it refembles a polecal being equally long, and fender. Its Ixin is blacker that that of an otter, or almolt any other creati: ${ }^{3}$ "as blac' 4s a mint" "being a prover bial expreffion in America it is not however fo valuable, though this greatly de pends on the feafon in which it is tuken. Its tail is round like that of a foake, but growing lattifh towards the end, and is entirely without hair. An agreeable mußy fcent exhales from its body and it is met with near th fonrces of rivers on whole banks it chiofly lives.

\section{QD The BRDS.}

The Eagle, the Hawk, the Night Hawk, the Filh Hark, the. Whippoorwill, the Raven, the Crow, the Owl, Parrots, the Pelican, the Crane, the Stork, the Cormoo rant, the Heron, the Swat, the Gorfe, Ducks, the Teal, the Loon, the Water Hen, the I urkey, the Heath Cock, the Partridge the Qnail, Figeons, the Snipe, Larks, the Woodpecker, the Cuckoo, the Blve JaJ, the Swallow, the Wakon Bird, the Bluck Bird, the Red Bird, the Thrulh, the Whetfat, the Nightingale, the King Bird, the Robin, the Wren, and the Humming Bird.

The EAGLE. There are onl ewo forts of eagles in thefe parte, the bald and the grey, which are much the fume in fise, and fimilar to the luape of gliofe of other countries.

The NIGHT HAWI. This bird is of the hawk Epecies, its bill betus crooked, its wings formed for fivillnefs, and its thape nearly lite that of the ennimon bawk $z$ bot in fize it is confiderably lefs, and in color rather darker. It is fcarcely ever feen but in the eveo ning, whes at twilight it ties about, and darts itfelf in wanton gambols at the head of the belinted travellet.

- Befure a viunter flower thele birds are feen at in amaz. ing height in the air affembled together in great num. lest, as fwallows are obferved to do on the fame occk. son.

The Indian onew! aly it the the ar met. As foo: etarn, hich furan it acqu eople. hip p rurde; trike th proof ertain siglt c won as on the od re ion till dibbitun a upon habits The is thap greael fometir Jovers. * drav them ail erin hure ho povier. certain medt of 61b. The is bas 
fublits in the sles a polecat - blacker thar res" "as blac' in America greatly de - tail is round towards the ceable mung with near the lives.

wh, the Fifh row, the Owl, ; the Cormo. cke, the Teal, - the Heath s, the Snipe, Blue Jay, the ird, the Red atingale, the pe Humming

its of eagles ch are much be of thofe of

of the hawk: s formed for the cnumion and in color at in the ere. ad darts itfelf ted traveller. in at an amaz. great nump. -5 fame occa.
The WHIPROORWILL, or as it is termed by the Jadians, the Muckatwifs. This extraordinary birl is omewhat like the laft mentioned in its flape and color. mily it has foine whitifh Riipes actols the wings, and ithe that is foldom feen till after fun fet. It alfo is ner. at met with but during the lpring and fummer months. As foon ac the Indisns are informed by its notes of its feturn, they conclude that the froft is entirely gone. in Thich they are foldom deceived o and on receiring this Jurance of milder weather, begin to fow stheir corn. it acquires its name by the noile it makts, which to the people of the colonies foinds like the name they give it thip poor-will, to an Indian ear muck-w. wiff. Ithe hurds, it is tr se, are nut alike, but in this manner they trike the imagination of eacia 8 and the circumftance is proof that the fame founds: is they are hot rendered artain by being reduce. 1 to the rules of orthography. hight convey different ideas to different psople ai Don as night comes on ti. fe birds will place themfelves in the fonces, Aurs ps, os $f:$ : "s thadivie near fome hnufe, nd repeat their melanc. lotes withoot any varia. ion till midnight. The Indians, and fome of the ine tabitunts of the back fettlements, think if this bird perche? as upon ans houfe, thitt it hetokens forne milhap to the masbitants of it.

The FISH H.IWK greatly, refembles the latter in as thape, and receives his nanse from his food, which is generally, fifh is it - ktims over the liakes and rivers and fometimes feems to lie expanded on the water, as he hovers fo clufe to it, and having by foine attrative pow. on drawn the fith within its reach, darts foddenly upon them The charm it mater ufe of is fuppofed to be an ail censtuined in a fmall bag in the body, and which na. ure has by fome meins or otlier, fupplied him with the povet of ufing for the purpofo, it is however very artain that any bait touched with a drop of the vil col. hoted from this bird is an irteliftible lure for all forts of 6th. and inflices the angler great fuceeft.

The OWL. The only fort of owls that is found on in banks of the Miffilippi is extremely beautiful in in 
plumage, being of a fine deep rellow of gold colur, pleafingly thaded and fpotted.

Whe CRANE There is a kind of crane in thefe parts, which is called by father Henipen a pelican, thas is about the fize of the European crane, of a greyilh color, and with long legs g but this fpecios differs from all others in its bill, which is about twelve inches long, and one irich and an half broad, of which breadth it continues to the end, where it is blunted, and round like a paddle, its tonguie is of the fimelength.

DUCKS. Among a variety of wild ducks, the dif. ferent fpecies of which amount to upwards of twenty I Pall confine my defcriptinn to one fort, that is; the wood duck, or, as the French term it, Canard Branch. us. I his, fun receives its name frum its frequerting the wouds and perching on the branches of trees, which no other water fowl (a characteriftic that this Aill pre: ferves) is known to do. It is nearly of a tize with other ducls; its plumage is beautifully vatiegated,and very brilliant the feth of it alfo,as it feeds but little on tith, is Sincly favored, and much fuperion to any otlier fort.

The I'EAL. I have already remarked in my jour. al, that the toal found on the For river and the bead bianches of the Milfifippi, are perhaps not to be equala ed for the fatnets apd delicacy of their fielt by uny oiher in the wotld. In color, Thape, and fize thes are very little diferent from thofe found in other countries.

The LOON is a water fowl, fomewhat lefs than a teal, and is tpecies of the dobchick. Its wings are thort, and its legs and feet large in proportion to the body i che color' of it is a darkbrown, nearly approach. 'ing to black, and as it feeds only on fith, the fich of it is very ill havoled. Thefe birds are exceedinglyi nimble and expert at diving, fo that it is almol impolfable for one perion to thost them, as they will dexterouly avoid the thot by diving before they reach them : fo that it requires three pertions to kill one of them, and this tan only be done the moment it raifes its head aut of the water as it recurns to the furface after diving. It how. ever only repays the trouble takeo to obtain its by the excellea fport it afiords. 
old colur,

$a$ in thefe lican, that a greyilh iffers from ches long, breadth it ind round h.

3s, the dif. of twenty at is, the d Bratich. requerting ees, which is Alll pre: with other idverybrille on thth, is itlier fort:

$n$ my jour. dithe bead be equale rany other

fare very atries:

lefs than a wings are tion to the approach. hieflo of it glyinimble poffible for suify avoid fo that it Id this bañ int of the It how. it, by the

The PARTRIDGE. There are three foris of partridges here, the brown. the red, and the black, the firt of which is molt elteemed. They are all much larger than the European partridges, being nearly the fize of a hen pheafant ; their head and ejes are alfo like that bird, and they have all long tails, which they fpread like a fan, but sot ered, but contrary to the cuftom of thofe in other countries, they will pereh on the branches of the poplar and black birch, on the buds of which they feed early in the morning and in the twilight of the evening, during the winze months, when they are cali. If thot.

The WOOD PIGEON is nearly the fame as ours, and there are frich prodigions quantities of them on the banks of the Mififippi, that they will fometimes darken the fun for feveral minutes.

The WOODPECKER. This is a very heautifu! bird o there is one fort whofe feathers are a mirture of various colors, and another that is brown all nver the bodf, except the head and neck, which are of a fine red. As this bird is ruppoled to make a greater noifo than ordinary at particalar times, it is conjesqured his cries then denote rain.

Ti.e BLEL JAY. This blrd is thaped neurly like the European jay, only that its tail is Innger. On the $t$ ip of its head is a creft of blue foathers, which is raifed or let Jowr at pleafure. Thie lower part of the neck behind, and the back, are of a purplith color. and the upper fide of the wings and tail, es well as the lovier part uf the back and rump, are of a fine blue, the extremities of the wings are blackilh, fitintly tinetured with dirk blice on the ejges, whilft the other parts of the wing are bared acrofs with black iti an eleg ant man. net. Upon the winte this bird can fearcely be exceeded in beauty by ans of the winged inhubitants of this of other climates. It has wie fame jetring motion that jays generally have, and its $\mathrm{cry}$ is far more pleafing:

The WAKON BIRD, as it is termed by the Indians, appears to be of the fume fpicies as the birds of para. dife. The nane they have given it, is exprettive of its fifferior cxcellence, and the veneration they have for its $\rightarrow 8$ 
the wakon bird beind in their langagat the Gird of the Cieat Spirit It is nearly the fice of a fuallow, of a brown color, thaded about the neck with a bright green the wiugs are of a darker brown than the body ; its tail is compoled of four or five feathers, which ars three times as lorg as its body, and which are beautifully thaded with green and purple. It carries this fine leogth of plumage in the fame manner as a peacock dues, but it is not known whether it ever raifes it in. to the ereet polition that that birds fometimes does. I never faw any-of thefe bird in the colonies, but the Naudovidtie Indtaris cau zht feveral of then when I was in theit country, und feemed to treat them as if they were of a fupetinr rank to any oiher of the feathered race.

The BLACK BHRD. There are thiree forts of birds in North imerica that bear this name, the firlt Is the common, or as it is there termed, the crow black bird, which is quite black, and of the fane fize and thape of thofe in liurope, tut it has not that mel. ndy in its notes which they have In the month of September this fort $y$ in large flights, and do great mifchief to the Indian corn, which is at that time juft ripe. The fecond fort is the red wing, which is racher Imaller than the firf $f$ pecies, but like that it is black all over its body, except on the lower rin ot the wings, where it is of a fine, bright full feariet It builds its neft, and chicfy reforts among the fmall bufies that grow in meacows and low, fwampy places. It whift. les a few notes, but is not equat in its fong to the Eu. ropean black bird. 't he third fort is of the fume fine as the latter, and is jet black like that but all the up. yer part of the wing, juft belo ir the black, is of $a$ fine clear white as if nature intended to diver lify the fpe. cies, and to atone for the want of a roelodious pipe by the beatuty of its piumage for this alfo is deficieat in its mufical powers. The beaks of every fort are of 2 full gellow, and the females of each of a ruay black like the European."

The RED BIRD is about the fize of a fparrow, but with a long tail and is all over of a bright vermillion color. I daw many of thea about the Ottawaw lakes,

but I in fom is el

Ihe that, $a$ mer of noife 1 The oe of t is ckille overy' bawk.

the which air, is Mitped inch Ic is prop defcrip fining the ba friall grace ceptib! pleation minitiv from overth movin thai th ing wh reteito

OR T

I ha taken' The Carp; 
ird of the blow, of a hi green : ; its tail art three fully thathis fine 2 peacock res it inmes does. but the hen I was as if they hered race. forts of - the firlt ow black e fize and that' mel. month of do great time juft is racher black all he wings, builds its ufies that It whit. o the Eu. fume fine all the up. of a fine fy the fpe: s pipe by eficient in $t$ are of 2 ify black

isrow, but vermillion vaw lakes, but $T$ could not learn that the fung 1 stho obferved in fome otlier parts a bird ot niveh the rame nuake, that oas entirely of a fine yeltow:

IThe WHEI'SA W is of the cuekoo kird, bring like that, a Dolitary bird, and rcarcely evel feen on the unimer monthe it ts hedra in the groves, where it prakes a noife The the filin of a ta for from which it receivesitsta wie. - The KITV HIKD is the a frillow, and feems 10 be of the fame fecies as the black martin or fwift-le is chlled the king bird becauferts is able ro na ${ }^{n} 4$ almot overy bird that'thes. Jialve often fee, t. downa hawk.

The HUMMING BERI This heautiful bird, which is the fmallen of the featlieted inhabitants of the air, is about the third.pute of the fize of a wren, and is thitped extremely lity it x It's leg's, which iare about an noch lóng appodr like two fmall needles, and its body is proportionable to them But its plumige exceeds defcription On its thend it has a fmall tuft of jetty, fhining black i the brealt of it is red the belly white, the back, wings, and tail of the finell pale green; and fmall fpecks of goid are fcattered with inexpreflible: grace over the whole; befides this, an almalt impre. ceptible down foftens the colors, and prodinoes the inct pleating thades. With its bill, which is of the fame dio minitive fize as the other parts of its body it extracts from the flowers a moilture which is its nourithm over thefe it hovers like a thee, but never lights on them, moving at the fame time its wigs with fych velocity that the motion of thert is imperecptible, notwithatand. in which they make a humming boife, from whence it. reteives its nan:e.

\section{OF THE FISHBS WHICH ARF TOUNDTSTHE DATFR OF. THB MISSISIPPt.}

I have already given a defcription of thofe that are taken in the great lakes.

The Stargeon, the Pout or Cat Filh, the Pike, the Carp, and the Chub. 
The STURGEON The frelh water Aurgeon is Thaped in no other refped like thofe taken near the fea, except in the furmation of its head and tail; which are fathioned in the fares manner, but the body is not fo an: gulated nor are there fo many horny fcales about it as on the latter, Its length is generally about two feet and $a$ liat on three fect long but in circunference not proportionable, being a lender fith. The teth is exced. ingly delicate and Fnels favored, I caught forne in the head waters of the jiver St Crois that tar exieed. ed trout The minner of taking them is by watching them as they lie under the banks in a clear fiream, and dartingat them with a fih $f$ pear, for they will nct take a bit. There is alfo in the Niffifppi, and there only, anotiver fort than the fpecies l havedefcribed, which is fmilar to it in event refped, escep that the upper jaw - stends fourteen or fifteen inches besond the under; this extenfive jaw, which is of a griftly fubltance, is three inches and a bilf broad, und continues of that breadth, Comes hat in the prape of an oar, to the end, which is flat. The fieth of this fim, however, is not ta be compased with the other fort, and is not fo much eftemed even by the Indiaris.

The CAT FISH. This filh is dbout eighteen inch. es longt of a brownilh color, and withopt fcales. It has a large rouna head, from whence it receives its pame, on differant parts of which grows three or four Arong, Tharp horns about two incties long its fins are allo ve. $r y$ bony and frong, and without great care will pierce the hands of thofe whordake tham. It weighs commonly about five or fix pounds, the fleth of it is excefivels fat and lufcious, and greatly refenbles that of an eel in its flavor.

The CARP and CHUB are much the fame as thofe ia England and nearly abous the fame fire.

or. StR suT.

The Rattle Snake, the Long Bluck Snake, the Wall - Houfe Adder, the Su jed or Garter Snite, the W is

ter $\mathrm{S}$ Thor the $\mathrm{I}$ Ph Specie terme thefe At th and $t$ great that $f$ and $t$ and $t$ brovr partc and $c$ gradu witole coiald artran: But atro every the fa a pali fides. upper its nat fubitat cellis and $w$ of the the inc concal and as thing $n$ prehen felf int the be either. In this 
Auigeon is ear the fea, which are is not fo an: about it as it two feet ference nnt Th is exceed. hit forne in tar exceed. W watching tream, and vill nct take there only, d, which is - upper jaw the under; nce, is three at breadth, which is flat. e compaised ned even by

hreen inch. fcales. It ves its pane, four fireng, are alco ve. it care will It weighs he Heth of $y$ refenbles

ime as thole

e. the Wall he, the twis ter Snake, the Hiffing Snake, the Green Snake, the Thorntail Snake, the Speckled Snake, the Ring Snake, the Fwo herded Snake.

The KATIIE SNAKE There appears to be two Species of this reptile, one of which is commonly termed the Black, and tlie other the Yellow, and of thefe the latier is generally confidered as the largeft. At their fall growth they are upwards of five feet long. and the middle part of the body, at which it is of the. greateft buik, meafures about nine inches round. Fran that part it gradually decreafes both towards the head and the tail the neck is proportionably very Imall and tho head broadand depreffed. thefe are of a light brown color, the iris of tho eye red, and, all the upper. part of the body brown, mixed with u ruddy yellow: and chequered with many regular lines of a deep black, gradualty thading towands a gold color. In fhort the whole of this dasgercus reptile, is very beantiful, and could it be viened with lels terr on fuch a variegated artingement of colors would betextremely pleating. But thele are only to be feew in their highell perfection at the time thic croasure is animated by refentment, then every tint rulles from its fubcutaneous recefs, and gives the furfice of the Ain a deeper Aain. the belly is of a paling blue, which grows fulier as it approaches the fides, and is at lengi h intermixed with the color of the upper part. The ratele at its tail, from which itkeceives its name, s compoled ot a firm, ury, callous, o borny fubftance if a light brown, und confits of a nu ber of cells which arciculate one wirhin snotbor, like joints: and which increafe every year, and makg known the age. of the crentire 1 Thefe articulations being very lonte. the included points Arike ag ainf the inner furface of the concave parts, or rings into which they ere admitted, and us the fnake vibrates, or thakes its cail makes a rate. thing noffe, This alarm is always given when it is ap. prehenlivo ot danger, and in an initant after forms itfelf into a. Spiral wreath, in the centre of which appear the bead oxeen and breathing forth vengeance again h either man or bea that thall dare to come near it. In this attitude he awdits the approach of his enemies; 
rattling his tail as he fees or hears them confing on. By this timely intimation, which heaven feems to have pro. vided as a means to counteract the mifchief this veno. mois reptile would otherwife be the perpetrator of, the unwary traveller is apprifed of his danger, and has an op. portunity of avniding it. it is however to be obforved, that it never acs offenfively. it heither purfes not fies from any thing that approaches it, but lies in the pofi. tion defcribed ratimg his tail as if reluctant to hurt. The to th with which this ferpent effets his poifonous purpotes are not thofo he thaties ufe of on ordinary $c c$. cafions, the site ont two hin number, very fmall and Tharp pointed, and fixt in a finews lubftunce that lies near the extremity of the upper jaw, refenbling the clatrs of a cat, as the root of each of thefe, might be extended, contrabledit or entirely hidden, ws need requires, are two fmall bladders which thitre has fo conAtrucied, thar at the fame inflant an incifion is made by the reeth, a drop of digreenth, polfonous liduid enters the wound, and taints with its deftruetive quality the whcle mafs of blood. In a motnent the unfortunate viain of its writh feets a chilly or mor run throngh all his framer $\&$ roiling innediately, begins on the fpow where the teeth thad enters, which fpread by de. grtes ove the whole body, and produces on every part of the fxid the variegated hue of the fanke. The bitc of this reptle is wore th lef seltoreous, ascording to the feafe of the year fi which it is given. In the dog daje, it wen proves inftenth thortal, and efpecially if the rovid is wate arbony the finews fiteated in the back part of the lez, bove the hets but in the fpring, in autumn, or during a cobl day which might happen in tho fummer, ify bed effects are to be ptevonted by the immedivte ap plication of propet temedies s and there Providencelias bounteouft friphied, by taufing the Ruttle Snake Mantatin, on approted tatidoys to the poi." fon of this sreature, to grow it great profifion where ever they wre to be niet with. There are likewife feve. ral other remedies befides this for the venom of its bite. A decoetion ts made of the buds of bark of the whito

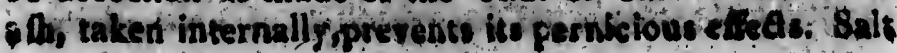

isin rely cure: bed.0 But migh degre turn ed thi it is $\mathrm{C}$ Eects. hog: ily de and and I is cha or int When

lifteni and $f$ ed. I bites, erea, os qu Ina 0 tore $b$ great placer tends reach, three to its 1 other er, an ly revi vice known found notwit a perfi than 
on. By ave pry. is Seno. $r$ of, the as an op. bferved, not flies the pofi. to hurt. oifonous nary ce. mall and nice that ling the. anight be nered res fo conmade by id enters iality die ortunate throvgh is on the by de iery part The bite rding to the dog ofpecially od in the - fprivis it thappen at the hind thefe ifing the o the poi-" in where wife fevefit biten the white as. Bals fi a newly difcorered remeds, and if applied immediItely to the part, or the wound be wafled with urine, cure might be afured. The tat of the reptile alfo rub. bed on it is frequendy found to be very efficacious. But though the lives of the perfons who have been bitten might be preforved by thefe, and their health in fome degree reflored, yot they anually experience a llight return of the dreadful f roptons about the time they ieceiv. ed the infillation. However remarkable it may appeat, it is certun, that though the venom of this creature afFects, in a greater or leis degree, all animated nature, the hog is an exception to the rule, as that animal will read. il deftroy them without dreading their poifonous fangs, and fatten on their fieth. It has been often obferved; and I can confirm the oblervation, that the Ratte Snake is charmed with any harmonious founds whecher vocal or inftrumental, I have many times feen thein, even Then they have been enraged, place themfelves in a liftening polture, and continue immoreably attertive and fufceptible of delight all the time the nufic has laft. ed. I Tould have reminked, that when the ratcle fnalk bites, it drops its under jar and holding the upper jaw erea, throws itfelf in 8 curve line with great force, and as quick as lightning, on the objea of its refentment In a moment after, it retarns areun to its defenfive pofo ture having difengaged it teeth from the wound with great celerity. by means of the polition in which it had placed its head when it made the attack. It never ex tends irfelf to a greater diftance than half its longth will reach, and thongh it fometimes repeats the blon two or three times, it as ofien retirns with a fudden rebound to its formet late. The black ratcle finake differs in no othat refpea from the yellow, than in being rather fmall. er, and in the tarigation of its collors, which are exad. ly reverfed one is black where the other is yellow; and vice verfa. 1 hey are equally renomcus It is not known how thefe creatures engender; $I$ have often found the eggs of feveral other fpecies of the fquke, but notwithltanding no one has taken more pains to acquire a perfect knowledge of every property of thete reptiles then myfelf, I nevor could difcover the axinuer in whicl 
they bring forth their young. I once killed a fetmale that had leventy young ones in its belly, but thefe were perfectiy formed, and $1 \mathrm{fw}$ them jull before retire to the mouth of their mother, a place of fecurity, on my approach, 1 tie gall of this ferpent, mixed with chalky are formed inta tituld bills, and exported from A merica, for medical purpores They are of the nature of Gafo coign's powders, and an escellent remedy for com. plaints incident to children. The fief of the frake alfo dried, ard made inte broth is much more butritive than that of vipers, and very efficacious agdinit confumptions. Whe LONG BIACK SNAKE There are alfo of two forts, both of which ate exactly fimilar is ftape and Sfite, only the betty of one is a light red, the other a faine blue , all the apper parts of their bodies are black and fcaly. They are in general froth fir to elght feet sil length, and carry their heads, as they ctawl along, about a 50 and a half from the ground. They ealily climb the highen trees in purfuit of birds and fquirrels which sre their shief food and thefe, it is faid, they charm by thelt looks, and rendes thicapeble of efcaping Fom them. Their appearance carties tertor with it to thofe who are anacquaint d with their inability to turt, but they are petfealy thottenfive and fré from venoth.

TTE STRIPED GT GARTER SNAKE, is exacty the fane as that Ipecies found in other climates.

Whe WA TER SNA trE is much like the rattle fuake in Thape and tize, but is ant endowed with the fame Tenomous powets, being quite harmlefs.

- Hhe HISSILE SNAKL I have already parlicularly dercribec, when 1 trested, in my journal, of Lake $\mathrm{E}$. tie

The GREEN SNAKE is about a foot and in half long, and in color fo near to grafs and herbs, that it cannot be difcotvered as it lies on the ground; hapily, however, it is free from venom, otherwife it would do an ihfinite deal of milchief, as thofe who pars through the meadows, not being able to peiceive it, are dsprived of the power of avoiding it.

Thie IHORN TATL, SNAKE. This replite is

Pound bo fee from

taint

Thi

boht :

Its fe

Jilan

the be

the fig

Th

the bic

thich

aerror

it freq

tore

Ch

of this

boat

o gent

lotd

1ite th

herds

ter this

propay

forthal

Whe

ape 1

Atr to

aherai

rate,

havaf

Claqui

difpor

we the

hous. 
2 felmale thefe were e retire to ty; on my ith ohalk, America, re of Gafo for com. frakéalfo fitive than fumptions. are alfo of Whape and io other a are black eight feet awi along, They eatily nd fánitrels iffid, they of efeaping trith' it to it to tiurt, efrom ven.

is exactly tíes.

rattle fuake h the fame

Setticalarly flake $\mathrm{E}$.

nd an half bs, that it id: Tapily; it would do is through re deprived replite is
Sound ilit many parts of A merica; but is vory feldon to be feen It is of a middle fize, and receives its name from a thorn like dart in its tail, with which it is faid ta in lijer a mortal wound.

The SPECKLED SNAIKE is an aqueous reptile 2. bojt two feet and an half in length but without venom. It fein which is brown and white, with fome fpots of Jllow in it, is ufed brithe Americans as a corer for the bandles ot whips, and it penders them pleafing 10 the figlit.

The RINC SNAKE is bout twelve inches long; the body of it is entirely black, except a yellow ring thich it has about its neck, and whish appears like nartow piece of riband vied round it. This odd repile it frequently found in the ibart of trees and among old his:

The TWO HEADED SNA KE. The only fnake of this tind that was ever feen in A merica, was found bout the year 1768 , near lake Champlain, by Mr. Park, - gentleman of New England, and made a prefent to lord Amberit. It was about a foot long, and in thape Tile the common fnake, but it was fuinithed, with twes heads exagly fimilar, which unired at the neek. Whethtit this was a difline fpecies of fnokes, and was able to propagate its theriefs, of whether it was an accidental fotmation, I know noc.

The TOR2OLSE or LAND TURTLE. The ape of this ereature is fo well known thet it is unnecef th to deleribe it there are feven or eighe forts of the in Americk fotne of which are beautifully varic. wated, oven beyond defeription. The thells of tany. herce fpots of red, green, and yellow in them, and the chequer work. is enmpofed of fmall fquares curivufy difpofed The molt beatuiful cort of thefe creatures are the imalleft, and the bitf of theth is faid to be verio mous.

\section{HzARDS, E":}

Whough there are numerous kinds of this clafs of the $\mathbf{x}$. 
aniznal creation, in the country I treat of, I thall only take notice of itwo of them; which are termed the Swift and Slow Lizard

The SWIFT LIZARD is about fix inches lons and has four legs and a tail. Its body, which is blue is prettily Itriped with dark lines thaded with jellow; out the end of the tail is totally blue. It is fo rethark. ably agile, that in an inftant it is out of fight, not can its riovement be perceived by the quickelt eye i $^{\circ} / 6$ that it might more juatly be faid to vanith, than to run away. This tpecies are fuppoled in poifon thofe they bitk, but are not dangerous, as they never attack perfons that ap. proach them, choofing rather to get fuddenily out of their reach.

The SLOW LIZARD is of the fame thape as the fwift, but its color is brown it is mpreover of 2 appo. fite difpofition, being altogether as Aow in its move. ments as the other is fwift. It is remurkable triat thefe lizards are extremely brittle, and will break off near tho tail as cafy as an icicle.

A mong the reptiles of North America, there is a fpecies of the tond, termed the TREI, TOAD, which is nearly of the fame thape as the common fort, but fmall. er and with larger claws. It is ufually found on trees, Aicking clofe to the bark, or lasing in the crevices of it; and fo nearly doas it refemble the color of the tree to which it cleaves, that it is with difficulty diltinguithed from it. Thefe creatures are only heard during the twilight of the morning and evening, er jult before and after a thourer of rain, when they mate a croaking noife fomewhat feriller than that of a frng, which might be heard ta a great diftance. Ther infelt the wnods in fuch numbers, that their refponfive notes at thefe times make the air refound. It is only a fummer animal, and oer or to de found during the vinter.

INSECTs.

ithe interior parts of North America abound will acaly the fame incests as ure met with in the fame par

allels of erous at the who fore con peculias Worm, and the The Prance ty of fill The and Gigi on its $x$ inch lon

The I ey in the who are

The ] the tize that infe - Crmet and the of coat, and $28 \mathrm{t}$ its body. ed ance 9 and thre as li fpr bods wh round. mignitu the exp vings, a night by more the fible of molt fuit they are They ar July, ani aight. 
Thall only ed the Swift

nohes long, ich is blue ith yellow: fo retuark. ht, not can je i lo that o run away. y bite, but fons that ap. enily out of

hape as the of an oppo. in its move. Ne tinat thefe off near tho

hore is a fpe. D, which is tt, but f'́mall. und on trees, evices of it : the tree to diltinguithed d during the At before and roaking noife ch might be roods in fuch e times make bal, and ner.

abound will the lame par allels of latitude and the fpecies of them are fo numb. crous and diverfified that even 2 fuccitst defeription of the whole of them would fill a volume; I thall therefore confine my felf to a few, which I believe are almof peculiar to this country; the Silk Worm, the I'obacco Worm, the Bee, the Lightning Bug, the Water Bug, ant the Hol ned, Bug.

The SILK WORM is nearly the fame as thole of France and Italy, but will not produce the fame quanti. ty of filk.

The TOBACCO WORM is a catterpillar of the fize and tigure of a filk worm, it is a fine fea green cclor, on its rump it has 2 fling or horn near a quarter of an inch long.

The BF,ES, in America principally lodge their hon. ey in the earth to fecure it from the rarages of the bears. who are remarkable fond of it.

The JIGH INING BUG or FIRE FLY is about the tize of a bee, but it is of the beetle kind, having like that infedt two pair of wings, the upper of whicil are of 2 frm testure, to defend it from dangur. When it flies, and the wings are espanded, there is under thefe a kind of coat, conltruted also like wings. Which is luminous and as the infect paffes ori, caufes all the hinder part of its body to appear, like a bright fiery coal. Having plac. ed pne of them on your hand, the under part only thines, and throws the light on the fpace beneath ; but as foors as it fpreads lte upper wings to fly away, the whole bods which lies behind them appears illuminated all a. round. The light it gives is not conftantly of the fame magnitude, oven when it flies, but feems to deperid on the expanfion or contraction of the luminous coat or wings, and is very different from that emitted in a durk night by dry wood or fome kinds of $6 \mathrm{~h}$, it having much more the appearance of real fire. They Teem to be fenable of the power they are poffeffed of, and to know the molt fuitable tine for exerting it, as in a very dirtk night they are much more numerous than at any other time. They are only feen during the fiummer months of June. July, and Augult, and then at no other time but in the aight. Whether from their color, which is of a dufks 
browa, they are not then difcerinable; or from their ta tiring to holet and crmices, I tubw not, but they are never to he difcovered in the day. Ithey chiefly are feen inilow fwampy dand, und appear tike innumerable tranfrient glenmo of light. In dark nightw when there is much lightning without rain they toen asilf they withed either to imiture or affitt the liathes $y$ for douring the intervals, they wre uncommonly agile, add endeavor to throw ont every ray they can colled. Notiwithtand. ing this effulgent appeiranse, thefe infeets are perfectiy. harmblef, gou may permit them to crawl upon yolis hand, when five or lix, if they freely exhibit thuirgluw

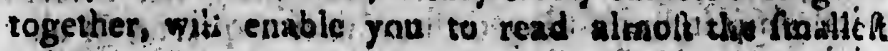
print.

The WATER BUGio of aibrewn color, about the fize of a pea, and in thape nearly oral it that mathy legs, by means of which it paffes over the turfece of the wa. tor wrih fadi tocreditie fwiftoefs, thet it feems to flide or dare ireif along.

The HORNED BUG, or as it is fometimes termed the STAG BEETLE, is of a dufty brown colot near. 3) s pprosching toblack, about an inch and an hall long, and haif an inoly broad. It has two large bort ths which gtow on each fide of the head, and mect horitinntally, aud with thefe it pinches vers hard/s thy we branched like thrienof a fag. from whones it receives its name. They Aly about in the evening, and proye very trouble. fornd to shofe who are in tho tields at ihat time.

-I Imuth not ondit that the LOCUST is a isforennial infect, as they are onty leeni, a friall nutiber of R raylets excepted, every feven years, thenithey infert the fe parts and toe interior colonies in lar go frampity and do de great doat of mifchiof: - The years when they thus trive are dreominated ithe loculf yeari.

The Hemlo the Bir Wickop Wood Iher black, it and t:u their ex the culo fcarcely cawed d the colo proper : from th finaller, wife as i teemed pliable, and is $e$ greacly Thape of nut tree neither 1 the latte 
thieir to. they are hiefly are intrierable hen there ailif they or during endeavor uthifind. perfectiy pun yolis ibsirigluw intowitich

about the many legs, of the war. n's to Alide

iestermed iolor near. hallfong, ons which risintally, -branched its name. r trouble. 6.

Seprennial in praylets helte parts 'do a great' htrive are $2-1.86$

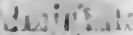

:18 5iti:

(i) $3111 \%$

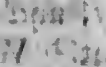


for fences, in which flate it will endure a confluerable time.

The PINE TREE That fpecies of the pine tree pecullar in this part of the continent, is the white, the quality of which I neid not deferibe, as the timber of it is fo well knona under the name of deals It grows here in great plenty, to an amazing hejgtt and fize, and yields an excellent turpentitis, though bot ta fich quan. citios as thofe in the northern parts of Eurupe.

The MA I. Of of this tre there are two forts, the Fard and the foft, both of which jibld a lufcious juice, f:om which the Indians, by boiling, make very good fugar. I'he fap of the former is much richer and fweet. er than the latter, but the foft produces a greater quan. tity. The wood of the hard maple is rery beautifully reined and curled, and when wrought into eabinets, ta. bles, gunltocks, ac is greatly valited thite of the foft fort differs in its texture, wanting the tatiegated grain of the hard it it alfo grows more thraight and free from branches, and is wore eatily folit It likewifemay be diltinguifhed from the hard, as this grows in meadows and low land, that on the bills and oplands. the leaves are chaped alike, but thofe of ilit folt maple are anch tive larg a, and of a decper green.

The ASH. There are feveraf forts of this tree in thefe parts, bue that to which If fhall confine my deferip. tion, is the yeltow all, which is only found wear the head branches of the Mitcifippi. This trce grows ic an amazing height, und the body of it is fis firm and fornd, that the French traders who go into that country from Louifiana, ro purchafe furs, make of them periaguays 3 this thes do by excavating them by fire, and when they are completed, convey in them the produce of their trade to New Orlean, where they find a good market both for their veftels and cargoes. Ithe rood of this tree grteatly' refembles that of the common aft's but it night be diflinguithed from any otber tree by its baik: the rols or out lido bark being ncar eight incties thick, and indented with furrows moro than fix inches dop, which make those that are arrived to a groás bolk appar oscommonir rough i and by this yectliarity they and

Whir

fime

fin

hind

not e

peel

tweet

a tine

it off.

not

ualue

I\%

Amer

It

leave

quite.

the in

Diaker

Th

dling:

when

foriten

dillves.

but "w.

rable.

II:

Specie

br a ip

and in

matites

thic In

pitch, s,

parpo:

a nallu

its sep

The

and on

Conootet

per for 
infuderablet

pine tree White, the imber of it It grows id fize, and frich quano: 0 forts, the cious juice, very good and fweet. sater quanbeautifully abinets, ta. of the foft jated grain free from ifferiay be a meadows the leaves - are anch

this tree in my idefcrip. id vear the grows iv an and found, puntry from periaguays 3 d when they ce of their ood market rood of this ahis but it py its bask: niches thick, nehét ditop; bulk speat they wing bet readhy strowth The rind or intide bark is of lie fame thicknets as that of other trees, but its color is of a Ge bright yeilow, infnmuch that if it is but fightly lizndled, it will leave $a$ fain on the firgers, which cannot eafly be wared away and if in the fpring you peel off the bark. and toucly the fap, which then riles be. tween that and the bridy of the tree, it will teave fo dicep a tineture that it dill sequire three or four da s so wear it off. Many ufeful qualities belong to this tree, to doubt not will be difeureted in time belides its proving $a$ val. uable aequifition to the dyer.

The IENLOCK ILEE graws in every part of Amesiod, in 1 greater or lefs degrec.

It is an evergreen of a very large gtowth, and has leaves fomewh th like that uf the yeir, it is hoverer quite ulielefs, and only axi incumbrance to the ground, the wood being of a kery'coarfe grain, and full of wind Dinkes or cracts.

The BASS or WLITE WOOD is a tree of a mid. dling fizes and the whiten and fofteft wuod that grows a when quited dry it: fwims on tive spater like a corks in the fettlements the turners make of it bowle, trenchers and dilues, which wear fmooth, and will waf a long time, but when applied to any other purpol it is fur from $t$ the rable.

The WICKOPIC or SUCKWIC appears to be a Ipecies of the white wood, and is dittinguithed from it br a peculiar quality in the bark, which when pounded, and moiftened with a litcle watter, inftantly becomes a matier of the confiflesice and nature of fize. With this the Indians pay their cauces, and it greatly exceeds pitch, or aby oither material afualls appropriated to thas purpofe, for belides its adhefive qualits, it is of fw oily a nature, that the warer cannot penetrate through $\mathrm{it}$, and its iepelling potier abates not for a confidorable time. The BUIION WOOD is a ire of the largel fize, and raight be difinguifled by its bark, which is quite crooth and prettily moteled the wood is very prop. per for the ufe of eabinet mukers. It is covered with fmall hard burs which fpring from its branches, that ap. 
pear not unlike buttons, and from thele it recuincs its viane.

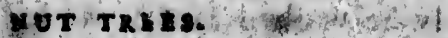

The Butter or Oil Nut, the Walnut, the Hazel Nut, the Beech Nut, the Pecan Nut, the Chefrut, the Hickory.

The BU PTER or OLL NUT As no mention has been made by any author of this nut, I fall be the mo:e particular in mi account of it. The tree grows in meadows where the foil is rich and warm. The body of it ieidom exceeds $z$ yard in circumterence, is full of tiranches, the twigs of which are fhort and blunt, and its leaves refemble thofe of a Walnut. The nut has a thell more like that fruit, which when ripe is more furrow. $\epsilon d$ and more eafily cracked; it is alfo much longer and larger than 2 walnut, and contains $a$ greater quantity of kernel, which is very oily, and of a rich agreeable flavor I am perfiaded that a much purer oil than that of olives might be extrakted fropm this nut. "I he infide bark of thi tree dies a good puple; and it is faic, varies in its thade according to the month in which it is gathered.

The BEECH NUT. Though this tree grows exad. ly like that of the fime rame in Europe, yet it produces nuts equally as good as chefnuts; on which bears, mar. tins, fyuirrels, patridges, turkies, and many other birds and beafts feed. The nut is contained, whilf growing, in an outfide cafe, like that of a chefnut, but not fo prickly; and the coat of the infide thell is alfo Imnoth like that ; only its form is nearly triangular. Valt quantities of them lit feuttered about in the woods, and fupply with food great numbers of the creatures juft ruentioned the leaves, which are white, enntinue on the trees the whole winter. A decostion made of them is a certain and expeditious cure for wounds which arife from berning or fealding; as well as a reftorative for thofe members that are nipped $t y$ the froft.

The PECAN NU'T is fome what of the walaut kipd,

but $x$ of a eafily nut.

Th bears. fait to: Bsing far th wood frop:

IIne ous pri the ad: ing.

The thapt Tiske. The therfin: fecond pored: 'the th quintil carain oritto

Tihe witar ahd It tity: 0 i

the much: roper

The in this fide, ai and in 
azel Nut, the Hick.

intion has ill be the grows in The body is. full of it, and its has a fbell furrow. onger and i quantity agreeable or oil than nut. "l' "l he ; and it is in which

rows exact. it produces bears, mar. bther birds A growing, but hot fo ifo ifmooth lar.: Valt the woods, creatures se, conntinue $h$ made of unds which reftorative sift: ralaut kipd,

but ratherifnaller than the walnut, being about the fit o of a midale acorn, and of an oval form the thell is eafily cracked, and the kequel thaped Jike that of $a \mathrm{mal}$. nut. This iree grows chi fly near the Ilirois River.

The HICKORY is alio of the valnut kind, and bearsa fonit nearly like that tree. There are feveral forts of them, which rarz only in the colpr of the wood. Buing of a very tough nature, the wood is generally ufed for the handles of axes \&e. If is alfo resy good fire wood, and is it butas, aqiercollant lugar ditils froaris:

\section{reUt7 TARE.}

II peed not to obfere that thefe are all the fpontaneous productions of nature, which hare never ; receifed:

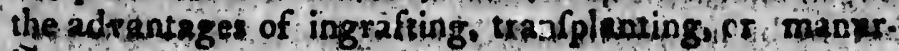
ing.

The Vine, the Mulberry Tree, the Crab Apple Tret. tha Plimb Tree, the Cherts Tree, and the s weet Gum 'Tiken:

The XINE is ver common here, and of threnkinds: therfinft forthandly deforvestche name of a grape, the fecond nuch relembles the Burtgunds grape, and if $6 x$. pofed to the fun a good wite might be mude of shem. the third refembles Zant currants, which are fofre: quively ured oul cakes, Qc. in Linglend, and if proper crteimhs: taken of them, would be equal if not fuperit orit to thiofei of that icouintry.

The WULBERRY, TRE E is of twa kinds red and webiteriandinearly of the lame fize of thiofo of Frianes and I taly, and grow ia fuch plenty is iso deed any quant. tity : oi itk woorme:

The CHit B APRLE TREE bears a fruit that is much llurger arid bektes flavored than thore of Lil: ropeitity ont

The PLUM TREE. There are two forts of plums in this country, one large fort of a purple caft on one fide, and red on the-reverfe, the fecond totaliy green, and much fmaller. Both thefe are of a good tavor, 
ard are greatly efecmed by the Indians, whofe tafte is not refined, but who are fatisfied with the productions of nature, in their unimproved fate

The CHERKY TKE. There are three forts of cherries in this country; the black, the red and the fand chetry the two latter may with more propriety be ranked among the thrubs, as the bufh that bears the fand cherries almol creeps along the ground, and the ather rifes, not above eight or ten feet in height, how. ever, I thill give an zecount of them in this place. The black cherries are about the lize of a curtent, and hang. in cluters, like grapes , the trees which bear them, be. ing very fruitful, the are generally loaded, but the fruit is not good to eat however, they give an agreea. ble fiavor to brandy, and turn it to the color of clartet. The red cherries grow in the greatel profution, and hang in bunehes, like the black fort jut defcribed; fo that the buthes which bear thom appedr at a diftance like folid bodies of red matter. Some people admire this fruit but the partake of the nature and tafte of alum, leaving 2 difagreeable roughtiefs in the throat, and being very aftringent. As I have alread defcrib. ed the fand cherries, which greatly exceed the two other forts both in flavor and fize, l thall give no farther defcription of them. The wood of the black cher: ry tree is very ufeful, and works well into cabinet: ware.

Wh SWEET GUM TREF or ILIQUID AM. BER (Copalm) is not only extremely common; but it: affords a balm the virtues of which are infinita Its. bark is black and hards and its weod fo terider and fup. ple, that when the tree is telled; you may draw from the. middle of it rods of five or fix feet in length. It can. not be employed in building or furniture, as it warps. continually. Its leaf is indented with fre points like a: Aar. This balra is reckoned by tho Indians to be an excellent febrifuge, and it cures in two or three days. 
- tafle is duetions

forts of the fand triety be ears the and the. t how: co. The and hans. hem, be. but the a agreenf clarret. uion, and. ithed; fo dillance le admire and talte he throat, 7 defcrib. the two no farther ack cher: to. cabinet:

1D. AM. on; but it: nita Its. and fup.: from the - Ir can. it warps. ints like a: 3 to be ans days.

\section{งHลองs.}

The Willow, Shin Wood, Sumac, Sufafras, the Prick. 1. Ah, Moole Wood, spoon Wood, Large Elder, 1)warf Elder, Poifonous Elder, Juniper, Shtub Oak, Steet Fern, the Liturel, the Witch Hazle, the Mirtle Wax Tree, Winter Green the Ferer BuA, the CranBerry Bufh, the Gooleberry bufh, the Current buh, the Whirtle Berry, the Raberry, the Black Berry, and the Choak Berry:

The WILLOW There afe feveral fpecies of the Willow, the molt remarkable of which is a fmall fort that grows on the bants of the Mifilippi, and fome other places adjacent. The bart of this Ihrub fupplies the beaver with its winter food, and where the water has walled the foil from its roots, they appear to confit of Gbres inter woven together like thread, the color of wlich Is of-an inexprefibly fine fcarlet, with this the Indians tinge many of the ornamental parts of their drefs.

SHIN WOOD. This extraordinary Mrub grows in the forefts, and rifing like a vine, runs near the ground for tix or eight feet, and then takes rrot again, in the fame thanner taling root, and fpringing up focceffively, one thalk corets a large fpace, this proves very troublefone to the halty trateller by ftriking againt his thins, and entangling his logs f from which it has ac. guired its name

The SASSAFRAS is a hood well known for its medicinal qualities. It might vith equal propriety be termed a tree as a Prub, as it fomotimes grows thirty. feat high ; but in general it does no, reach higher thin thore of the thrub kind The leares, which yield an $a$. gredable fiagrance, are large, and nearly feparated into three divifions. It bears a reddith brown berrir, of the Gze and Thape of Pimento, and which is fimolimes ufed in the colnnies as a fubltitute for that fuice. I he baik or roots of this tree, is infnitely fuperior to the wood for its ufe in medicine, and $I$ am furprifed it is fo feldom to bo met witb,as its efficacy is fo much greater

The PRICKLY ASH is a thrub that Jometimes grows to the height of ten or fifteen feet; and has a leaf 
eracly refembling that of aa ah, but it receives the ep. ithet to its name from the abundapes of fhort thorns Fith which every bianch is coveted, and which renders it very troublefome to thofe who pafs through ghe fpot where they graw thick, It alio bears a fcarlet berry, Which when ripe, has th fiers tafte, like pepper. The bark of this tree, particularls the bark of the roots, is highly efteemed by the natives for its madicinal qualilies I hars already menaioned ohe infance of its eff. cacy, and there is no doubt but that the decostion of it will expeditiout and tadically remone all inpurities of the blood:

The MOOSE WOOD grows about four feet high, and if very full of brariches y but what zenders it worth notice, is its bark, which is of to Arong and pliable a texture, that being peled of at any sealon and twifted, makes equally as good cordage ts hemp.

The SPOON WOOD is a focies of the thurel, and the wopd when faved rerembles bos wood.

The ELUER commonly termed tho poifonous el. der, nearly refembles the othor fort in its loares and branches, but it grows much freighter, and is only found in fwamprand moin folls th his thrub is en. Howed with a very extraondinats quality that, readers it poifonous to fome conllitnejons, which it efiects if the perfon only approaches within $\mathrm{g}$ fen jards of it, whilf others may even chev the learea or the rind with. out receiving the lealt dotriment from them : the poifon howaver, is not mortal, though it opperates very vio. lenily ot che infected perfon, whiofe body and bead f well to anamazing fize, and ore covered with eruptions, thet at their height refemble the confuent fmall pox. As it growediso in many of the provinces the inbabitants cure its renom by drinling fferon tea, and annoint. ing the external parts with o mitute cotonpaled of cream and marfh mallows.

The SHINUB OAK is exnaly finilar to the oak' tree, both in wood and leaves, and like that it beas s an aconn, but it never rifes from the giound abote four or fire fet, growing crooked and knovity. It is foutediabichy a a dry gravell s foil 
ves the ep. ort thorns icts renders ho the fpot rlet berry, iptr. The iefoots, is inal quali. of irs eff.jation of it apurities of

$r$ feet high, ers it worth dipliable a ind twifted,

tarel, and

oifonons el. leaves and and is only lirub is en. thit, renders it elfects if fards of it, he rind with- the poifon es very vio. d head friell $h$ eruptions, friall pux. the iribabit. and annoint. sompared of

the oak tree, ais an acomn, four or fixe otredichicfly
The PITPL RAZI E grove very buhy, about ton tees linh, and is covesed early in Mas with nume. Ions white blolums. Whe this thrub is in bloom, the Indians eficem it a furthr indication that the frolt is 4 Cotirely gone, and that the mighe fon their corn. It thas bees:fid, that it is polieffad of the poter of attraes. 108 gold or filver, and that twige of it are hade ufe of to dufcoter witise he veins of the retels lie hid; but 1 am teprehenlife this is only a falacións fort, and, $10 t$ to be depended bn hopevet that foppolition bas viven is the name of Witch Hazls.

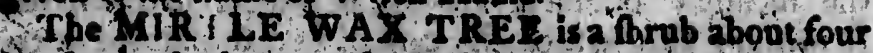
At high, the leaves of which are larget than tho of The comimon mirtle, but they foell exialy alike. It Wars it fruit in bunches, the a polegay, rifing from

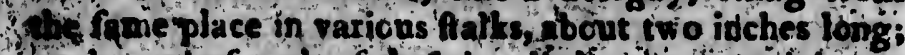
Tt the end of each of lhete is a litule huit, containing ? Hetnel, which is wholls covered thith a gluey fubAarice, Whith being boiled in water, fwims on the forface of it; rapd beconies a kind of green $\mathrm{wa}^{2}$ this is more valua He than bees wax, baing of a focre britile nature bit mixed with it makes a good candle, which as it burns, rends torth an agreeable cent.

VINTLR GREEN. This is an ever green, of the fpectes of the inyrtle, and is found on dry heaths ; the Aowers of it are vivite, ard in the form of a refe, bu not lavger than a fivet funy s in the winter it is Filcf red berries, about the tize of a Ace, which are fitooth and iound the are preterred during the fe. Terofealpn by lie rro, ard are at this tim in the hishelt perffation Ithe lödians eat thefe berries, $f$ teaming them vary balfanic, and invigarting to the fou ach The people inhabiting the inserior colonied tieep both the fprigs and berries in beet, and ufe it as ilet drink for eleanfing the blöed from fcorbitic dilor: Ors.

The FIVER BUSH grows about five or lix feef. high its leaf is like that of a lilach, and it bears areddih terry of a fpicy lawor. Ife Aatls of it are excehrely tritue. A decelicn of the huds of voce is at $\mathbf{Y}$ 
- Etcallent fobrifuge, arid from this valuhble propetty

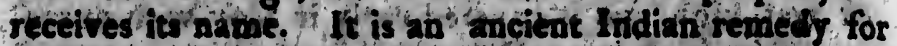

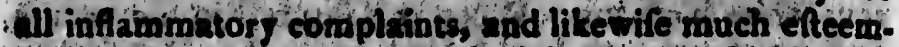

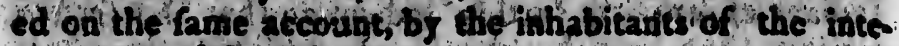
rior parti of the colónies.

The CRANDERNY BUSH. Though the finit of thit buth greatly recepoles in fize and appearatuce that of the combotfot which grows on a finall the, in morafes hrid bogs, the the ball rans to the height of ten or twelve fects but it is vits rarels to be twet tith. As the meadow cranbetry, boing of $100 \mathrm{l}$ grovth, and flourithing only in thoralles carnot be tranfilanted or cul-

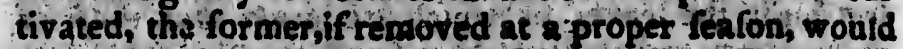
be arvaluable acquiliton to the grtaen, and wh prop. er nurture, prove equally as gond if not botter.

The CHOAK BERRY. The thrub thus tetithed by the natives grows about five or fix feet high, and bears a berry about the fize of 2 fow of a fot black, which con. tains feveral fmall feeds withio the pulp. The fuice of this fruit, though not of a difig feeable favor, is extremeIf tart, and leaves a roughnd in the mouth and throat when eaten, that has gained it the name of choal baxy.

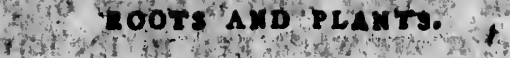

Elecaulpang, Spikonard, Angelica, Sartaparilla Gin. rang, Ground Nuts, Wild Potatoes, Liquorict, Snake Ruot, Cold Thread, Solomon's Sel, Devil's Bit Blood Hoot, Onjors, Garlick, Wild Parinips, Mandrales, Hellebore Whiteand Black.

SPIKLNA RD, valgarly called in the Colonies Petty. Mortel This plant bppears to be exally the fitules the Afiatic fpikenard, fo much valued by the ancisth. Tt grows near the fides of brook in roeky places atd its ftem which is about the fze of a goofe dnill, tpuss up like that of ángelica, teaching aljout a font and an half from the ground. It bears bunches of beties lat il feipects like thote of the elder, only rather larget. There wo of fucl a balfinic nature, that when lofuced in loir 
perty

inct for heftedin. the inte-

he finit of ance that 11 the, in ight of ten vith. As it th, and tred or cul. conis would whe prop. r.

us tetined and bears Which con. he juice of is etreme. and throat toál betry.

arilla Gin. tifet: Snake 5 Bit Btood drates, fiel.

onics Petty. the rative as be anclitils. plates ond uill, Sputiss. oot and an betries latell got. There. incedin tepir. in they make a moft palatable and reviving cordial. SASSAPARILLA The root of this plant, which is the mols etimable pass of it, is abour the tire of goofe gaill, and runs in difitrent directions twined and crooked to a great length in the ground f from the principat fers of it Coring man) cmalle f. bers, all of which are toingh and ferible. From the root immediately thoots a talk about 2 fool and a half long, which at the top branches into three Roms, each of thefe has three leaves much of the Shapeand fize of 2 walnut leaf; and from the fork of each of the threa femi grows a bunch of bluifh white flowers refembling thote of the fikegard the bark of the roots, which alone lhould be ured in modicine, is of a bitteribi havor but atomaric. It is defervedly es. ceemed for its medicisal virtues, being a gentle fudorilic, and vers powerful in attenuling: the blood, when impeded by grofs humors

GINSANG is 2 root that was once fuppofed to grom onl 7 in Kores, from whence it was uffall $z$ exported to. Jtppan and by that moans fond its w2y into Europe: Jut it has beep lately difcorered to be a patiye of North America, wheke, it grows to as great perfection, apd is equatly valuable Its root is ike a fmall carroo but not fo taper at the end, it is fometimes divided into feve. ral branches, in all other refpeets it refembles fafaparilla in its growth. The tafie of the ront is bitterifh. In the eaftern parts of Afia it bears a great price, being there confidered as a, panncen and is the laft refage of the inhatitants in all diforders. When chevod if certanly is aspat Areng thener of the Aopach.

GOLDTHRTAD. This is a plant of the imall Sine lind whish grows in fwamp places, and lies on

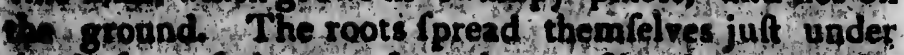
Th lurface of the mprafs, and are enfily dreve up by fapdinls. They relemble a large entangled foin of thent of a fine, bright gold color, and $1 \mathrm{am}$ perfuh.

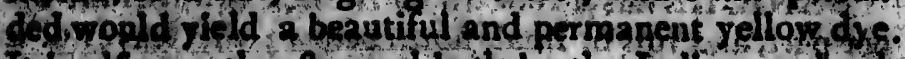

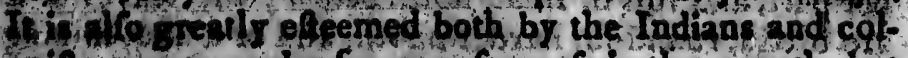
The 20 remed of or any forenefs in the mouth, hus the tinte of it is exquifitely bitter. 
SOLOMON's SEAL is a plant that fowren the fides of sivers, and in rich meadow land it tilles in the whde to dbout chree feet hith, the falls being twa feet. When the leaves begin to fpread themilelves and reach a foot futtlit. I partin evety root hax an ingtefiton up. on it about the fige of 2 itxpenes, which appeats to if it. was made by of fel, and rom there.it receives its name. It is grently valued on sccount of its being 2 fine puri: for of the blood.

DEVIIt' BIT is another wild plane which grows in the fields, and receives its nane from a print that feems to be made by teeth in the roots. The Indiane foy that. this wos once a univer fill remi of for every diforder thint homan nature is incident to but fome of the evil (pirits en cine' gare the root a bite, which deprived it of 2 great part of its virtue.

HiOOD KOOr. A fort of plantain that fprings out of the ground in fis or feven long rough letres the veins of which are red, the rook of it is like a friall car. rot, bath in color and appeartince $s$ when brolen, the inllas of it is of a desper color than che oulfade, and diftils feveral dropt of juigh, that look tike blood. This is - ftroog emetic, buk a very daggerous one.

\section{mans.}

Baim, Nictiles, Cinque Foil, Eyebright, Sanicle, Phase. tain, Rtrist Stalke Plantain, Poor Rolin s Plantain Troad Plantuin, Maiden Hlair, Wild Docks Rock Livintorts Noble Liverwort, Blerodwort, Wild Beann, Crownd Ivy, Water Croffes, Yarron, May Wead, Cargith Btunk Cabbage or Pole, Wake Robia, Beton, Beabrons, Miof len, Wild Peafe, Moure Ear, Wild Iadifo, Tobaceo and Cat Mint.

SANICLE has a root which is thick towarde chote?

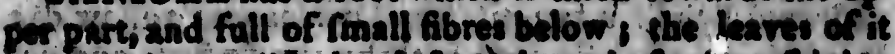

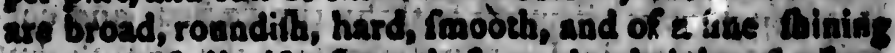

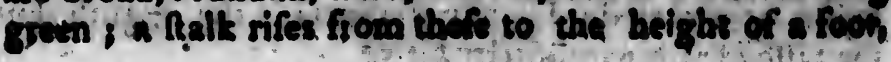




\section{CRRVER'S TRAVELS.}

non thie ice in the two feet. 1 reach a offlon up. are as if it. its name. fine puria,

sorows in. diat ferms: ne foy that. Corder that evil (pirits s a nadiof a groat

at fprings. Lebres, the. a criall car. frotion, the de, and difa. This is.

hicle, Hare athing 10ad Iivienorts stound IVy. Git. Otunt buans, Nito obnceso and Whave es is itas Diaitis os of a best which is quite forboth and free from knots, and on the to 2 of it are feverd thall flowers of a redilh white, lia. ped like a wild rofe. A tea made of the root is vulnar. ary and balfativic.

RATTLE SNAKS PLANTAIN. This ufeful herb is of the plantain ktud, and its leaves, which fpreed themeltes on the ground, are about one inch and an balf wide, and five inches long ; from the centre of thefe arifes a fnall Aalk, nearly fix inches lotg, which bears a little white fower, the root is about the fie of a goofe quill; and much beat, and divided into feveral branchts. The leaves of this herb are more effeacious than ahy other part of it for the bite of the reptile from which it receives it name $i$ and bẹing chewed and applied ining. diately to the wound, and fore of the juice Iwallow, feldom fails of averting every dangerouls frmptom. So convinced are the Indians of the povite of this infallible antidote, that for a trifing brite of f peritous liquor, this will at any time permit a ratele fnake to drive his fangs into their felh. It is to be ravintled that during thole months in which the bite of thefe creatures is moft vho omous, that this retwedy fur it is in its greateft perfection, and mof luxurianc in its growth.

POQR ROBIN's PLAN TAIN is of the fame $\mathrm{f}$ :cies as the laft, but wutr diminutive in every refpect if recrives its hame from its fire, and the poor land on which it grows. - Itis a goot medicinal herbs and often ad. minifered with fuccels in fevets and internal weakneti: es.

TOAD PLANMAIN recmbles the comition pleintain only it growt much ranker, and is this denomina. wd, becaufe toads love to hábor under it.

BOCK LIVERWOK' is a foit or Liverwort that grown on rocks, and is of the nature of kelp or mols. It isefieemed an excellent remedy againf dectines.

CARGII or SKOKE is a large kind of weed the leuves of which are about fix inches long and two inches. and an haif broad i they refrmble thofe cf fpinage in. their color and texture, but not in Pape. "Ihe root is. very large, from which Spring differeut falkd that ren 14 
eight os ten feet high, and are full of red berries: There hang in cluffers in the month of September, and are gen. erally called pigeon berries, as thole birds then feed on thom When the leaves firt Ipring from the grouad, afrer being boiled, they are a nutritions and pholefome vegetable, but when they are grown noarly to their full Gis, they asquire a poilonous quality. The roots ap. plied to the hands or feet of a perfon afilited with a fe. ver, prove a very powerful abrorbent.

SKUNA CABBAGE of ROKE is an herb that grows in moilt and frampy places. The lenves of it are about 2 foot long, and fit inches byoad, nearly oval, but rather pointed. The roots are compoled of grtat num. bers of fibres, a lotion of which is anade ure of by the people in the colonies for the cure of the itch. There illoes a fiong mulk fmell from this herb, fomething. He the animal of the fame name before deferibed, and po that account it is fo termed.

WAKE ROBIN is an herb that grows in Iwampy lands; its ropt refermbles a fmall turnip, and if tafted will greatly inflime the tongue, and immediately convert it from ite natural hape into 2 round hard fublance; in which fate it vill cpntinge for fowe time, and during this no other part of the month will be afiected. But when dried, it lofes in altringent quality, and becomes. Woeficial to minkind, for if grated inta cold water, and chea internally, it is vexy good for all complaints of the sowels.

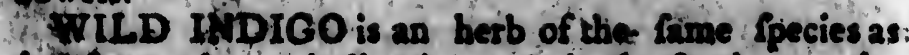
of n whpee Indigo is made in, be fouthorn colo. nite. It grows in one thill to the beight of fre or fix inches from the groupd when it divides into many bran. chess from thich iflec a great number of fmall hard Wewilh leaves thasf fo wad to a great breadth, and imong liefe it bears a yelich lower 8 the juice of it has a very: tifogremable fcent.

CAT MIN I bns a noods root, divided into. Coveral branches, and it finds lorth a falls about three feet. Ligh; the kaves are like thof of the nettle or betony, apd the have a fropg fmell of mint, with a biting ac

\section{.}


$\therefore$ Thefe dare gena ceed on grouad, wholefome their full roots apwith 2 fe.

herb that es of it are coral, but reat num. of by the h. There fomething: ribed, and

in framps id if tafled. iately con. 1 frubfance; and during and. But a. becormes. water, and hinis of the

e flpecies as: chern colo. f five or fix. many bran. Imall hard and among. has 2 very:

ato. feveral three feet. or betony, biting 20.
Wid tafte t the flowers gran on the tops of the branchies, andare of a faint purple or whitith color. It is called eat mint, becanfe it is frid cats tave an antipathy to its and will not let it groves. It has neatly the virtue of cose. mon mint.

\section{rLOWRES}

Heart's Eafe, Lillies red and yellow, Pond Lillier, Cowtlips, Moy. Flowers, Jefrimine, Honeyfuckles, Rock: Honeyfuekles, Rofos red and whice, Wild Hollyboct. Wild Pinks, and Golden Rod.

I Thall not enter into 2 minute defeription of the flowers above recired, but only juft oblerve, that the r much veferable thofe of the fame name which grom in Europe, and are as beausiful in collor, and as perfect in odor, as they can be luppoled to be in their vild, uncultivated. Atace.

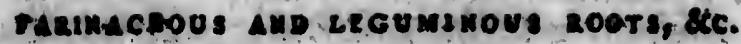

\section{Mrise or Indian Corn, Wild +Rice, Beans, the Squath;} ac.

MAIZE OI INDJAN CORN grow from fix to tea feet high, on a fall full of joints, which is ftiffand folid, and when yreen abounding with a freet juice. Theleaves wre like thofo of the reed, about two feet in length, and chree or four inches broad. The flowers which areproduced at fome diftance from tho truit on, the farme. plant, grom like the ears of oats, and are fometimes - wite, yellow, or a purple color. The feeds are as large as peale, snd lits them quite naked and imooth, but of aroundith furface, rether compreffed. One fnike gener. Ally confifs of about lis hundored grains, which are pla. eed clofely together in rews so the numbet of eight or ten, and rometimes tralve. This corn is very whole.

- For an account of Tobacco, lee 2.treatife. J have pub. Itimed an the culture of that plant. 
fome, dafy of digeflobs and jields as good nourifhinent as any other fort After the ludians hive rediuced it cuto meal by pounding it, ther thake calkes of it, abd bake them before the fire. I have already mentioned that fome nations eat it in cakes before it is ripe, in which fate it is very agreeable to the palate, and extremely nu. tritive. ind

WLL RICE This grain, which grows in the greatelt plenty throughout the interior parts of Noth America, is the nolt valuable of all the fpontaneous productions of that country. - Exclufive of its utility as a fupply of food for thole of the truman fpecies, who inhabit this part of the continent, and obtained without any other trouble that that of gathering it in; the freet-

- nefs and nutritious quality of itattracks an infinite num. ber of wild fowls of every kind, toltich foek from diftant climes, to enjoy this rare repalt; and by it become inexpreffibly fat and delicious. 'In future periods it will be of great fervice to the infant colonies, as it will afford them a prefent iupport, until in the courfe of cultivation, other fupplios may be produced; whereas in thofe realms which are not furrailhed with this bounteous gift of nature, even if the climate is temperate and the foil goow, the firft fettlers are often expofed to great hard. thips from the want of in immediate refour ce for neceffary food. This ufeful grain grows in the water where it is about two feet deep, and where it finds $a$ rich, mud. dy foil. The ftalks of it, and the brinches or ears that bear the feed, retemble oati both in their appoarance and manner of grawing. The ftalks are full of joints, and rife more than eigh feet above the water. The natives gather the grain in the following manner \& nearly about the time that 'it begins to turn from its milky fate and to ripen, they run their canoes into the mide of it, and tying buncher of it together, jult below the enrs, with bark, leave it th this fituation thee or four weeks lon. er, sill it is pettedly ripe. About the tatter end of Sep. tember they return to the river, when each family hav. ing its feparate alocment, and being able to diltinguilh theit own property by the manoer of faltening the 
uxifhüent cediuced it and bake oned that in which emely nu.

wo in the of Notth ontaneous iutility as s, who in. d without the fweetinite num. om diftant some inexsit will be will afford ultivation, 3 in thofe nteous gift ad the foil reat hardfor necerater where: rich, mudtr ears that arance and: oints, and the natives arrly about Crate and of 'it, and enrs, with céles lon: end of Sept mily hav. dilinguirh exing the

Wheaves, gather in the portion that: belongs to them: This they do by pleciog their canses clofe to the bunchcof rice, in fuch polition as for reseive the grain when it falls and then beat it outh with pieces of wood form. ad fos that purpole. Having done this, they dry it with fmoke, and afterwards tread or mb off the outfide husks whin it is-fit for ufe the pre it into the ltins of fawhs, or young buffalos, taken of nearly whole for this puxpofe; and ferved into a fort of faci, sherein they: prefervc.ititill, the return of their barvelt. It has been. the fubjest of mach fpeculation, why this fpontaneous: giais is not found in any other rcgions of A merica, or. in thof countries fituated in the fame parallels of latio. tude, where the waters are, as apparantly adapied for its. growth as in the climats I treat of As for inftance, wone of the countries that lie to the fouth and eaft of the: great lakes, even from the provinces north of the Caroliand, to the extremities of I abrador, produce any of this : strin. It is true I found great quantities of it in the watered lands near. Detroit; between lake Huyon and lake Erie, but on enquiry I learned that it never arriv. ad nearer to maturity than juft to bloflom; after which. it appeared blighted and died amay. This convinces me that the north wef wind, as I bave before hinted, is. woveh more powerful in thefe than in the interior parts; and that it is more inimical to the finuts of the earth. af ver it has paffed over tho lakes, and become united with the wind which joins it from the frozen regions of the north, than it is fartber to the.weft ward.

BEANS. Thefe are nearly of the fame thape as the. Duropean beans, but are not.much lasger than the fruallaft fize of them. They are boiled by the Indians, and i earen chiefly with bear's flelh.

The SQUASH: They have alfo feveral tpecies of: the. Melon or. Pumplin, which by forme are colled fquath. as, and, whieh ferve many nations partly as a fubftitute for bread: Of chefe there is the round, the crans neck a. che frolli fac, and the large cublong fquaft. The f malls. ex fons bein zboiled; are eatea during gho fommer a ver:- 


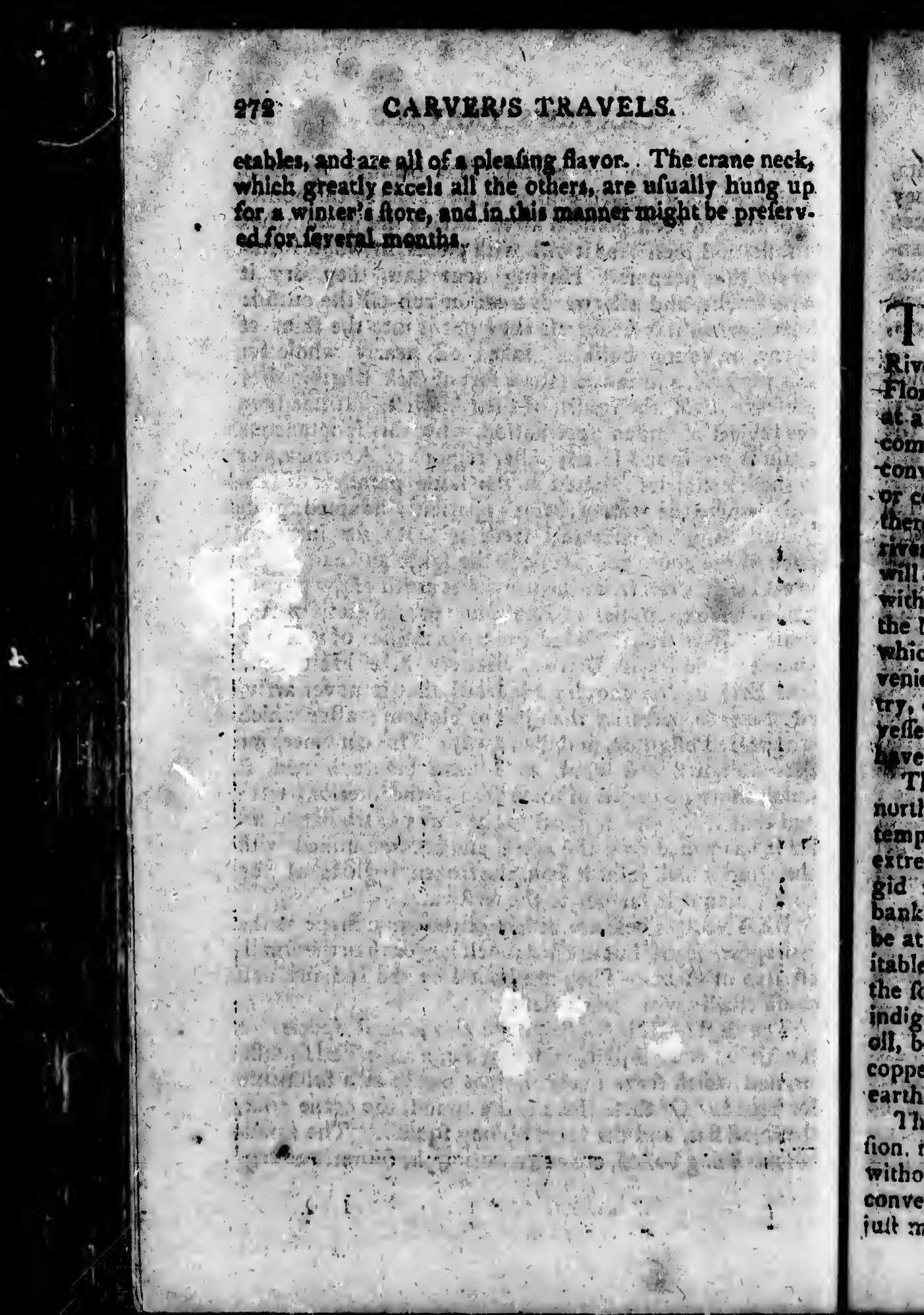


ane neck, hung up. preserv.

\section{APPENDIX.}

ing

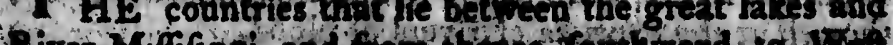

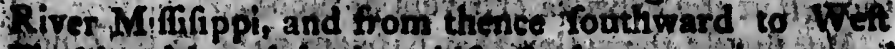
Tlorids, although in the midf of 1 a ge contintent, and

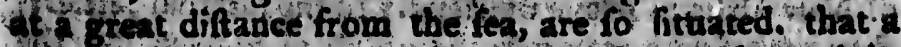
compunction between then and other realus migtit tonvediently be opented; by which means thofe, eppires of celonies that may hereafter be founded or planted thoton, wili be rendered commercial ones. The gredt in Mififip pi, which tans through the whole of them, Wil inable their inhabitants to effithlif an intercourfe With forction climes, equally as well a's the Euphrates, the Nile, the Danube, or the Wolga do thofe people which dwell on their banks, and who have to other con venience tor exporting the produce of their own cotin. try or for impotting thofe of others, then boats and treftels of light burden; notwithlanding which, they ve become powerful and opulent Rtates.

The Mifflippi, as I have before obferved, runs from nurth to fouth, and palfes throog h the molt fertile and temperate part of North America, dzeluding onty the extremities of it, which rerge both on the torrid ana fri fid zones. Thus favoribly fituated, when once its banks are carered with inhabitants, the need not long be at a lors for means ro eltabilith an exterfive and prof. itable commerce. Thev will find the country'towards the fouth ilmolt-fpontaneoufly producing filk, cotton, indigo, and tobacco, ind the more northerp parts, wind

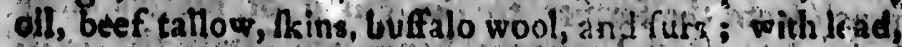
copper, iron, coals, fumber, corh, rice, and truirs, befides earth and barks fot dring.

There articles, with which it abounds even to profe. fion. may be tratiported to the occtin throngh thistivet Fithout gieater diffictily than that which attends the convegance of merchandife down foma of thofe I have fult mentioned. It is true rist tho Miffifippi being tht 
Foundary between the Englih and Spanilh fettements,

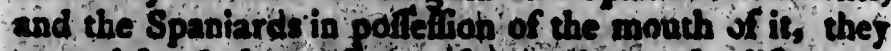
mas obirue the puthe of it and gteaty ditherien thole who make the firf atrempts st thet when the advan. tages that will certainly arife to fetlets, are known, innt. ritudes of adventurere, allured by the profpea of fuch abupdant riches will fock to is and eftabith themfel res,

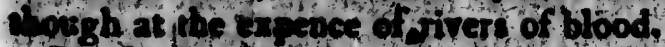

But honld the nation that happens so be in portefion of NE Orleans prove unfriendly to the intetnal citulers, The may find a way into the guiph of Merice, by the river Jberville shich enjptos ifh from the Mitiloppi; afler pating through lo ke Mantés, into lale Ponchaj. train, thich bas a communichti s widh the fen within the borders of Wef Norida. The river Iterville branch.

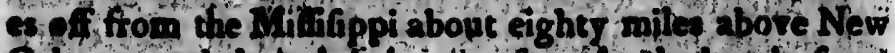
Orleans, and thotigh it is at prefent choskd up in fome

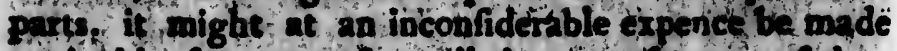
navigable to as 10 antwe all the purpoles propoled.

Although the Inglith bave acguired fince the lat pece a mora extenfive knowledge of the interior parts than were ever obtained befpre, even by the French, yet twany of their productions ofll remain oritnown. And though 1 vas nbe defcient ether in aftuduity or atten tion durigg tie thort time 1 remained in them, jet I muf ac thowled that the intelligence I gained was not To perfeg as I could with, and that it requires further folenrches to thate the world thoroughly asquainted tith the reil withe of liefe long fidden theims.

The parts of the Nithip of which no furty y has hith. erto bein taken, thount of fnlwards of eighte hundied

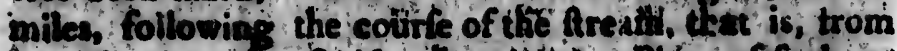
the Illingis to the Ouifcontin ritath Plins of fich as

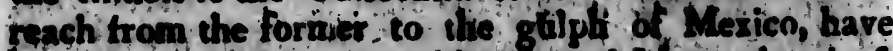
been delingated by Averal hands and 1 bate che pleaftre to find that an actual furvë, of the thtermediate parts of the Miffifph, between the Mllinois rive: and the (ct, thich the Ohio, Chicrokes, and Ouabache rivers, ta. ken on the fpot by $x$ very ingenious gentecunn, is now

- Thomas 'Hutchings, efq captain is his majefty's 6oth be reyal Ameripta refluicut of feot. 
deméńts, iis, the litheriten se advan: ma mult of of fuch emícl res,

poifefition 1 revilers, o, by the Mneffippis; Potchar. ce. vithin lic branch. Bote New ipia Comé be made ropoled. ce the lint erior parts French, yet no. And or atteti hem, Jet I ed was not res further acquainted is.

iy bids hiththundred tis, trom of fich as tien, have - the pleartermediate ter and the siversita $\mathrm{n}$, is now efty's boths

ptiblithed. 1 fatter myfelf that the oblervations these. in contrined, which have been made by one whof knowledge of the parts therein defcribed was acquired by a per onal invertigation, aided by a folid judgment. will confirm the remaits 1 have made, and promote the plan I am here recommending.

I Thall alio heré give concile deltription of each, beginning, according to the rule of geographorf, with that which lies molt to tlie north.

It is horeve neceffary to obferve, that betore thefe Rettlements an be effablified, grants thint be procured in the manner cuftomary on fuch occafions and the larids be purchafed of thofe who have acquired a right to them by a long poffeflion but no greater difficulty with attend the conpletion of this point, than the original founders uf eveiy colony on the contipent met with to obfruet their intedtions, and the number of Indiaus who inhabit thefe trats being greatly inadequare to their extent, it is not to be doubted, but they will readify give vp for a reafonable confideration, territories that are of little ufe to them or remove for the accommodation of their new neigtbots, to lands at a gredter diftance from the Militippt, the navigation of which is not eflen tial to the welfäre of their comm tuinities.

No. 1. The country within thefe lines, from its fitu. ation is colder than any of the others s Jet $I$ an con vinced that the air is much mone temperate than in thole provioces that lie in the latite degree of latitude to the eaft of it. The foil is excillent, and there is a Breat deal ct land that is free from woods in the parts adjoining to the Miffifippi, whilt on the contrary the north ealtern borders of it are well wooded To. wards the head of the river St. Croid, rice grows ii great plents and there is abundance of copper. Though the falls of St A nthony dre fitiated at the fouth eat corner of this divilion, yet that impediment will not cotalty obfrugt the vavigation, as the river $S x$. Croix, which suns through a great part of the fouthern fide of it, enters the Mililippi is it below the talls, and 
flows with o gentle a current, that it affords a contea ient navigation for boats This trat is about one hun dred miles froin north weit to fouch eat, and one hun. dred and twent miles from north eaft to fouth wolt.

No. It This trae, as I have alread teferibed it in m) Journal, exceeds the highilt encomiums I can give it: notwithtanding which it is entirely uninhabited, and the profufion of bletings that tacure has frovered on this hearenly fpot, return unenjojed to the fap fromi whence they lprang I Iake Pepin, as I have termed it after the French, lies within thefe bounds; but the Inl to which that name properly belongs is a litile abote the river St Croix; however, as all the traders ozll the lower lake by that name, I have fo denoninated it con. trary to the information I received from the Indiahs. This colony fring in unequal angles, the dimenfious of it canoot be esactly givets but it appears to be on an avarage about on hundre 1 and ten miles long, and eighty brodd.

No. I11. The greateft part of this divifion is fitualed on the River Duirconln, which is navigabie for boats de bout one hundred and eighy miles, bill it teaches the car. rying place that divides it from the Tos kiver. The land which is contained within its lindits is in tome parts movthainous, and in the other confits of fertile detd.

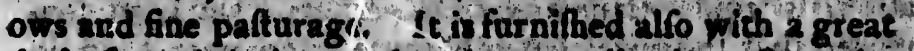
deal of good timber, and, as gy generally the cale on the banks of the Miflifpi und its brandkes das much fine, open, clear land, proper tor cultivition. po therede adued an inexhaultible luod of riche tit a number of leads mines which lies at a litile diftance from the Ouifeottia towards the fouth, and appear to be uncommonty fulf of ois. Although the Sankies ond Ottaganties Inhabit a part of this tract, the whole ot the land under their calgl tivation does not exceed thre hurdited acres it is in length fiom eaft to welt about one hundred and bft miles, and about eighty from worth to pouth.

No. IV. This colony confifte of lands of various de nominations, fowe of wifich are very good, and otliche very bad. The bett is lituated on the borders of the 
Green Bay and the Fox River, where there are innumerable acres covered with fine grafs, moft part of which grows to an aftonithing height. This river will afford 2 good navigation for boats throughout the whole of its courfe, which is about one huodred and eighty miles, ex. cept between ths Winnebago l.ake and the Green Bay ; where thire are feveral carrying places in the fpace of thirty miles. The Fox River is rendered remarkable by. the abundance of rice that grows on its fhores, and the almoft infinite numbers of wild fowl that frequent its banks. The land which lies near it appears to be vory fertile, and promíles to prodace a fufficient fupply of the neceflaries of life for any number of inhabitants. communication might be opeaed by thofe who thall fet. tie here, either throygh the Green Bay, Lake Michigan, Lake Furon, Lake Erie, and Lake Ontarion with Canada, or by way of the Ouifconfin into the Miffifippi. This divition is about one hundred and fixty miles long from north to fouth, and one hundred and forty broad.

No. V. This is an excellent traet of land, and, confid. ering its jinterior fituation, has greater "advantages thas could be expeAted ; for having the Millifippi on its weftern borders, and, the Illinois on its fouth-eaft, it has as free a navigation as molt of the others. 'The northern parts of it ure formewhat mountainous, btit it contains a great deal of clear land, the foil of which is excellent, with many fine fertile meadows, and not a few rich mines. It is upwards of two hundred miles from north so fouth, and one hundred and fifty from eaft to wef.

No. VI. This colony being fituated upon the heads of the Rivers Illinois and Ouabache, the former of which empties itfelf immediately into the Miffifippi. and the latter into the favie river by means of the Ohio, will readily find a communication with the fea through thefo. Having allo the Kiver Miamis palling through it which runs into Lake Erie, an intercourfe might be ellablifhed with Canada alfo by way of the lakes, as before pointed ont It cont: ins a great deal of rich fertile land, and though more inland than any of the ochers, will be as saluable an acguifition as the beft of them. From noth 22 and othets ders of the 


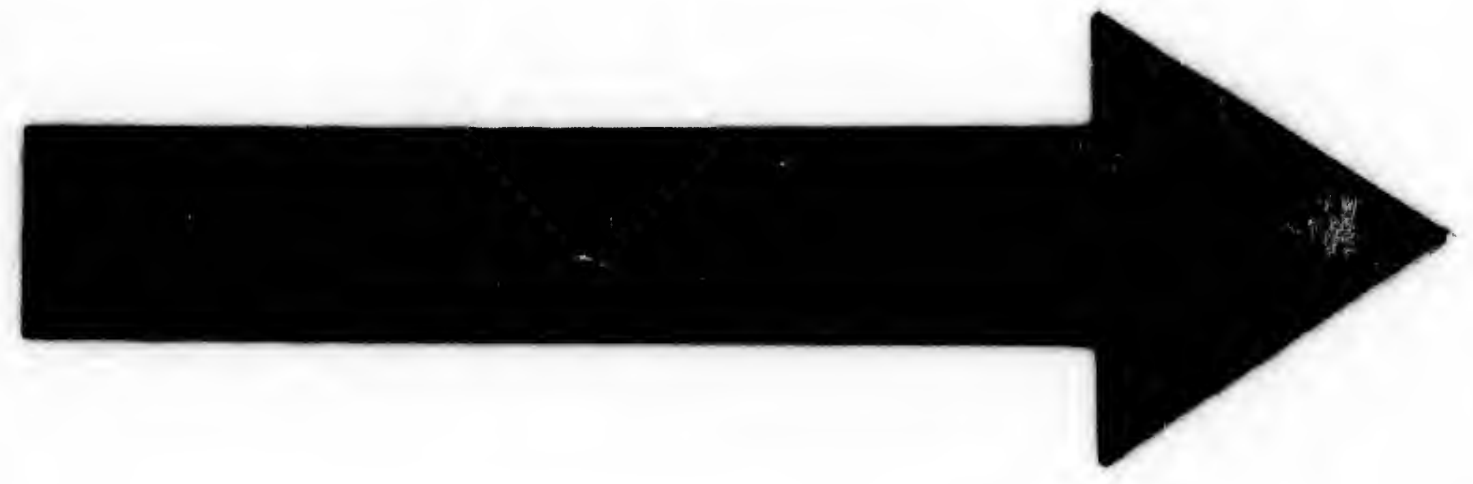




\section{IMAGE EVALUATION \\ TEST TARGET (MT-3)}
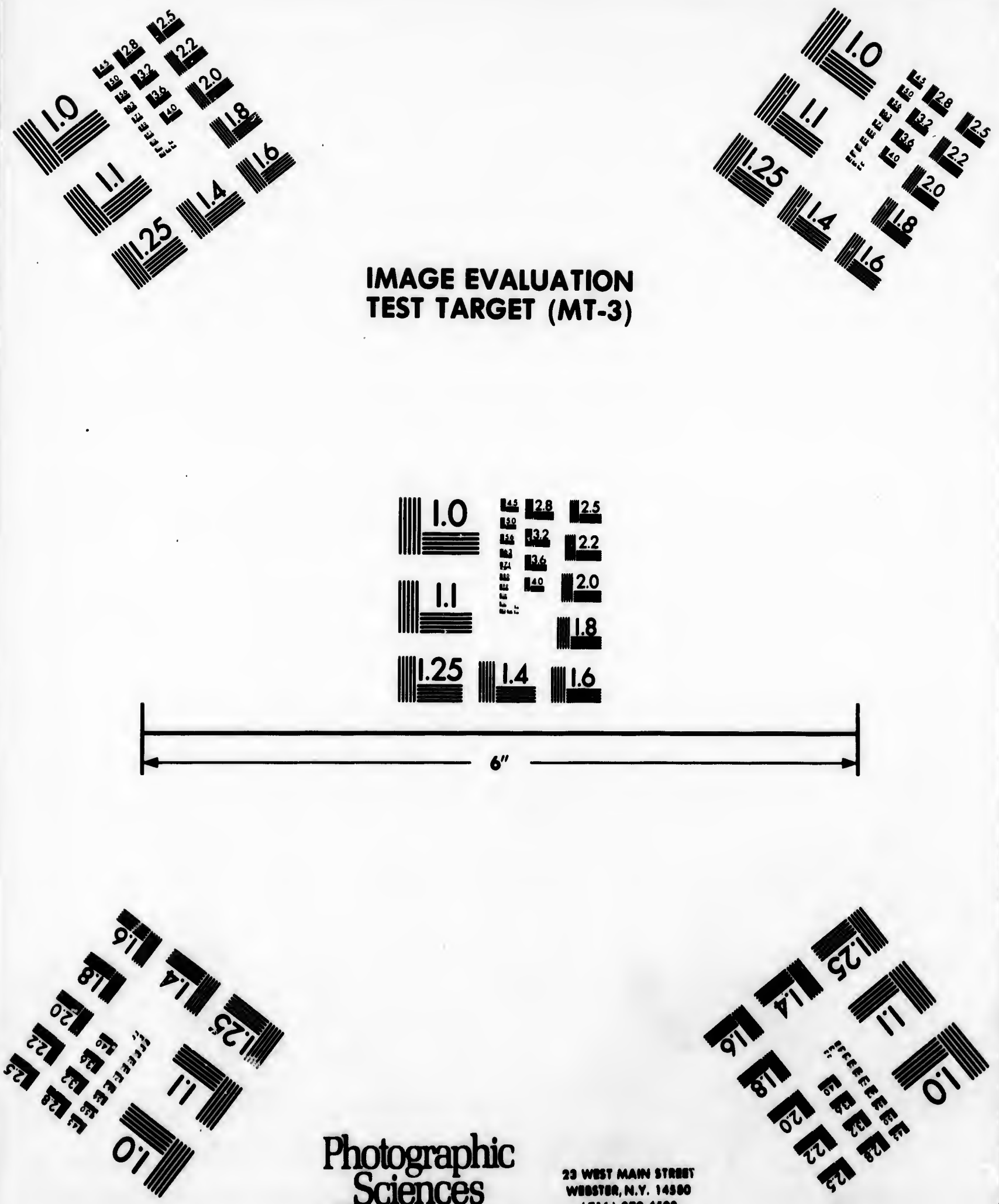

Photographic Sciences
Corporation

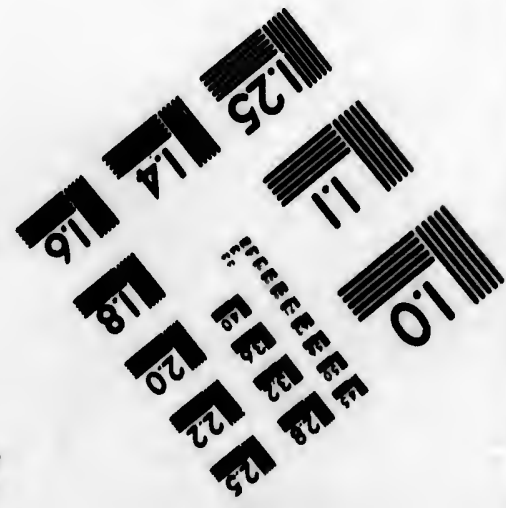

(716) 072-4803 
to fouth it is about one hundred and fixty miles, from eaft to weft one hundred and eighty.

No VII. This divifion is not inferiof to any of the toregoing. Its northern borders lying adjacent to the Thinois river, and its weltern to the Milfitippi, the ftua. tio of it for effablithing a commercial intercourfe with forcign nations is very commodious. It abounds with all the neceffaries of life, and is about one hundred and fifty miles from north to fouth, and fixiy miles from caft to welt f but the confines of it being more irregular that the others, I ennot exadly a feertrin the dimenfions of it

No. VUI. This colony having the River Ouabache running through the centre of it, and the Ohio for its fouthern boundary, woll onjoy the advantages of a free. navigation. It exiende about bue hundred and forty miles fróm norch so south, and one hundred and thire from call to woth

No. 1X $X$ and XI. being fimilar in fituation, and furritioe nith nearly the fame cunveniences as all the others, Ifyil only give their dimenfione No.IX is avat eifhty miles each way, but not exactly fquare. No. $x$ is nearly the rame form, and about the vame exteot. Nu XI is much larger, being at leaft onehundred and fitty wiles from north to fouth, and one hundred and forty from ealt to wef, 2 s nearly es from its irtegularis it is politble to calculate.

After the defcription of this delightful counery I have alreadrugiven, I heed nof repoat thet all the fonts I have thus pointed out a proper for colonization, abound not only with the neceffaries of life, being well fored sith rice, deer, buffaloet, bears, \& 2 . but produce ineg in bundance fuch as was be termed fuxuries, or at least tholo articles of, commerce before recited which the in: habitants of it will beve an opportunity of exchinging for the neodful produdions of orher countries.

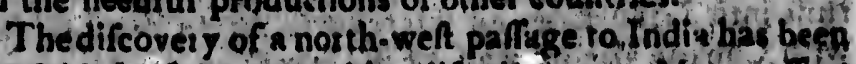
the fubject of innumerable difquilitions. Many effow

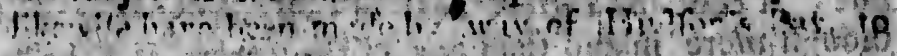
t! 
let, from

ay of the int to the the fituzsurfe with inds with adred and friom caft guler that ifions of it Ouabache. hin for its of a free. and forts: and thirt

antion, and ins all the No.IX. is Als fquare. $e$ came exonehundied undred and irtegulatist

ntry I have Ponts I have abound not nored with ineget 8 or at least hich the in: exchengin? 3.

diwhat been Many elfor

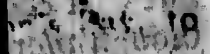

\section{APRENDIX.}

249

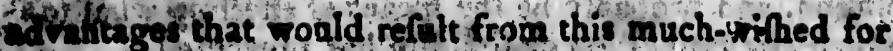

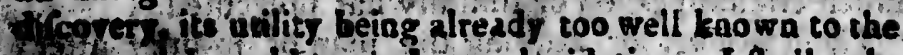
303 ted corld to weed any elucitation, I thall only con 7 frolf to the merhods that appear moft probable 4) the fuces to future adzenturers.

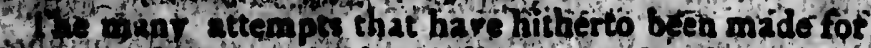
thif spols bat which have all boen rendered aborcive, Po to bave turied too fpirit of making ufeful relearches Acto other channel, and this mol interelting one bas

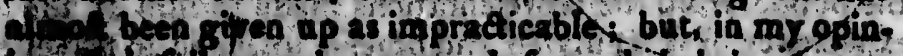
10. If titlure rather probeds from their teing began - Th inpioper plece that from thair impraticabilite. All havigetord tha hare hitherto gone in farch of

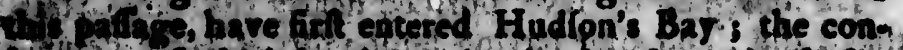

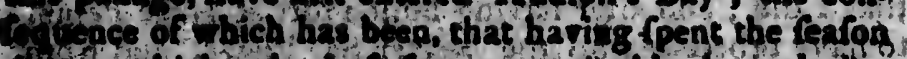

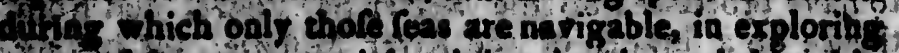

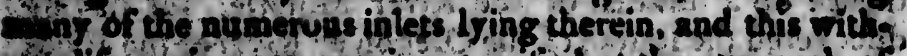

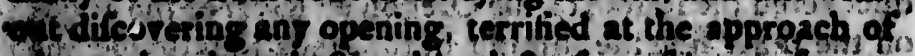
Wher they be te haluned back for fear of beiof fromen.

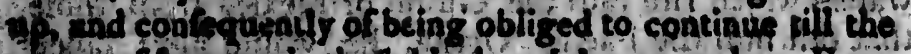

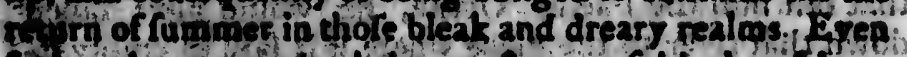

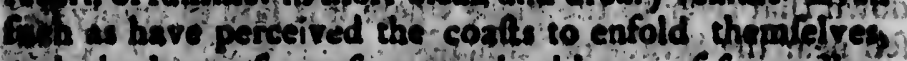
W who have of courfe entar uined hopes of fuche the

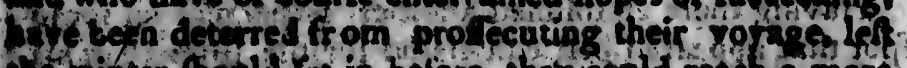

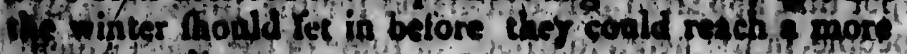
Qitherate climate.

jy perate climale.

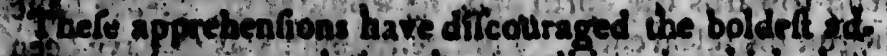

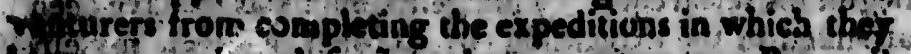

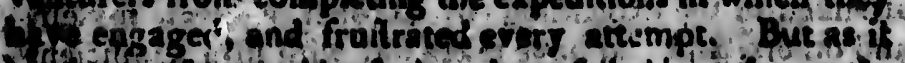

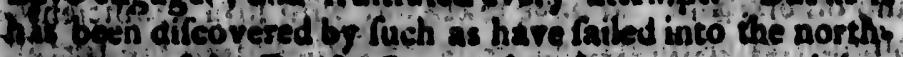
ot ts of the Pacific Oeean, that thent are meny inlqts

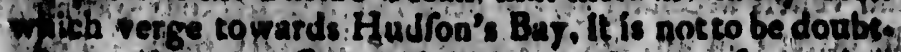
C. but that a pelage anight be made olut from that aty or if it be foughe for at a proper Ceaton And

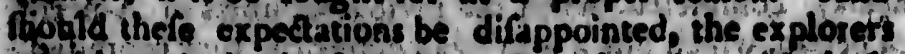
3utd not be in the rame hazdrdous fituation with thaf

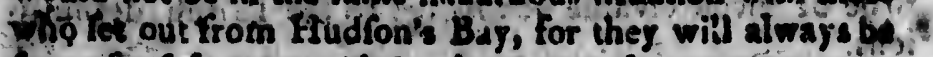
furs of a fafe ret: eat; through un open fea, to warmer red. rigus, ever affer repented difappointments. And this Contidenes will enable thes to prosëed with greater tofs. 
